\title{
EVOLUTION OF THE
}

\section{NORTH HOROWHENUA COASTAL}

\section{DEPOSITIONAL SYSTEM IN RESPONSE}

\author{
TO LATE PLEISTOCENE
}

SEA LEVEL CHANGES

By:

Glenn Richard Hughes

A thesis submitted for the partial fulfilment for the degree

Masters of Science with Honours in Geology

School of Earth Sciences

Victoria University of Wellington

2005 


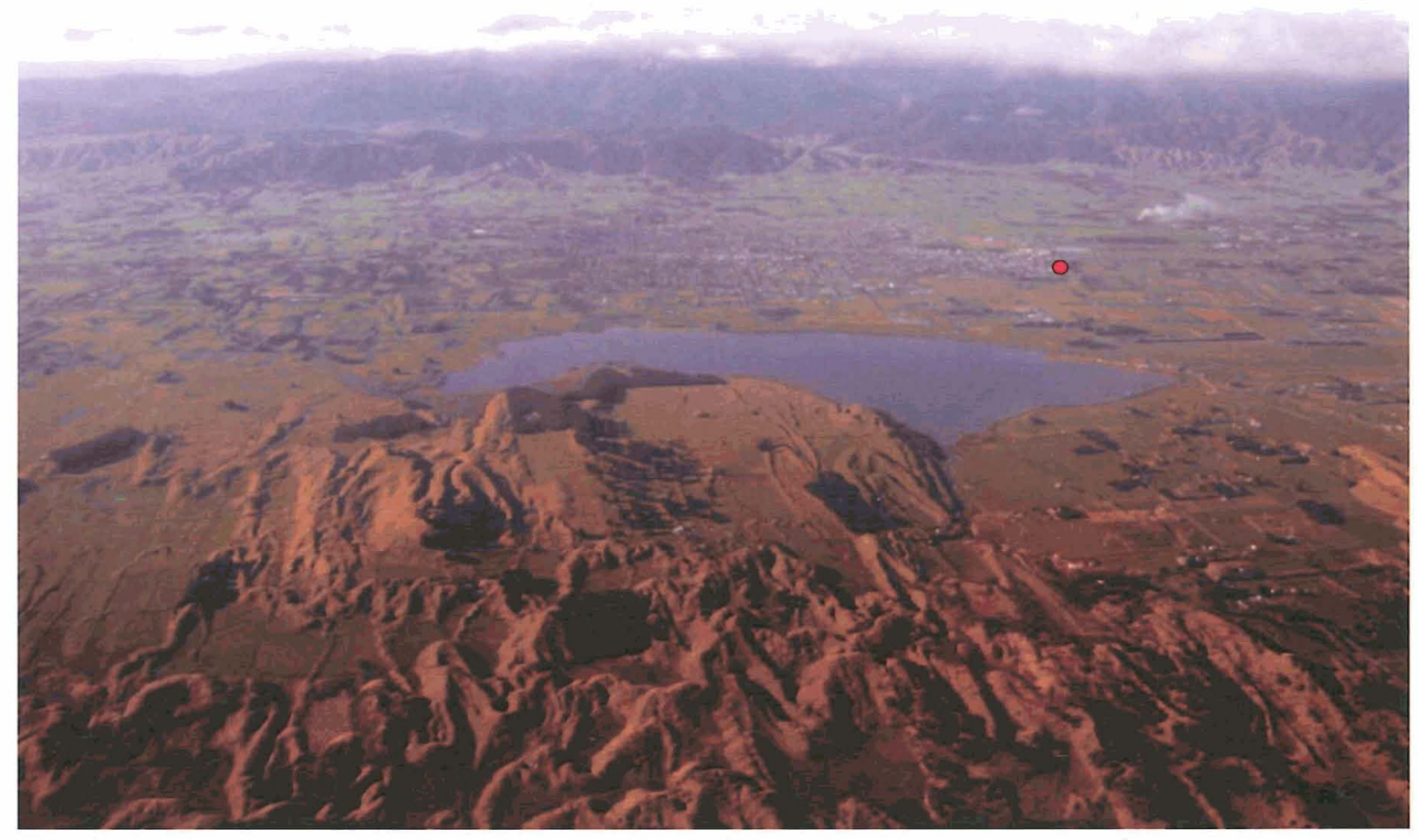

Frontispiece: Oblique aerial photograph of the study area looking east towards the Tararua Range with Lake Horowhenua and Levin in the foreground. The red dot indicates the approximate location of the Levin borehole. (Photo: VUW/Geonet, 2004). 


\begin{abstract}
The convergent tectonic setting of New Zealand has lead to the development of a series of anticlines and troughs resulting from folding and faulting of basement greywacke in southwest North Island. The most extensive of these is the Kairanga Trough spreading from the Horowhenua to the Manawatu, which lies between the uplifting Tararua Range and subsiding South Wanganui Basin. This trough was a major depocentre for fluvial and shallow marine strata during the Quaternary. By utilising a $280 \mathrm{~m}$ deep borehole from the Kairanga Trough, this thesis investigated how climate and sea level variations affected sedimentation in the north Horowhenua District.
\end{abstract}

This borehole has recorded a near continuous record of climate and sea level change for the last $340 \mathrm{ka}$. The lower part of the core is a marine sequence representing progressive infilling of the Kairanga Trough during $5^{\text {th }}$ order (c.100ka) glacioeustatic fluctuations, which consequently produced 4 marine cyclothems. Transgressions and subsequent highstand periods are represented by shallow marine sediment, which were followed by fluvial aggradation during lowstand periods, then marine planation during subsequent transgressions. Cycle 1 developed during OIS 9 (340-300ka). Cycles 2 and 3 both formed during OIS 7 as a result of two closely spaced highstands centred around $245 \mathrm{ka}$ (OIS 7c) and 200ka (OIS 7a), separated by a period of lower sea level around 225ka (OIS 7b) that produced a disconformity. Cycle 4 formed during the Last Interglacial transgression (OIS 5e) and represents an incised valley fill. Progradation of a coastal strandplain and alluvial plain representing the latter stages of infilling of the Kairanga Trough with coastal and terrigenous sediment during the mid to late Last Interglacial and Glacial Periods is recorded in the top part of the borehole. 


\section{ACKNOWLEDGEMENTS}

There are quite a few people I would like to thank for making this thesis possible. Firstly I would like to thank David Kennedy and Mike Hannah from Victoria University for their awesome supervision and motivation in the pursuit of answers. Also thanks to staff at VUW including: John Carter, Stuart Bush, and John Patterson for their help in the analytical facilities; John Collen and Steven Eagar for helping with the identification of fossils; Bill McLea for helping with palynomorph identification; and Richard Hawke for supplying some data. Also thanks to Rachael Armour for processing my samples for pollen and John Patterson for his brilliant photography.

I also had a bit of help from outside of VUW. Brent Alloway (IGNS) and Brad Pillans (ANU) supplied valuable tephra data and Brent helped with the correlation process thank you. I am grateful of Anthony Edwards of Stratigraphic Solutions Ltd. (Waikanae) who studied nannofossils in some of my samples. Also this project wouldn't have been possible without the drillers and staff of Neville Webb and Sons Drilling Ltd. (Levin) who carefully collected samples and kept an accurate log of the borehole.

Big ups to the honours class of 2003 for getting me though part 1, and to office mates Mike Millar, Joe Prebble, and Errol Cameron (fellow BOP supporter) for their constant feedback and well appreciated distractions. Also thanks to my parents for financial support while at Victoria University.

Finally, I would like to thank Horizons.mw for financing this project and staff Clare McCarron and Gabor Bekesi (now at Otago Regional Council) for making this project possible.

Cher cher 


\section{TABLE OF CONTENTS}

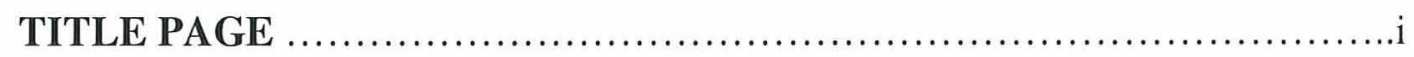

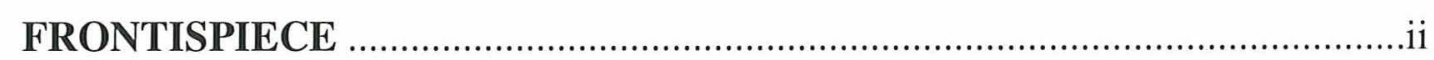

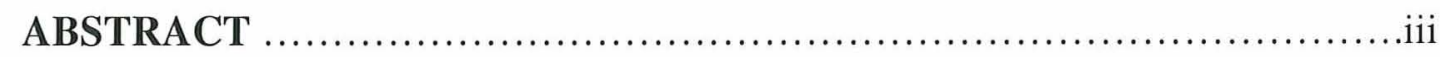

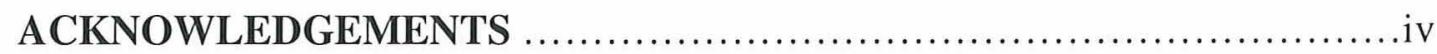

\section{CHAPTER 1 INTRODUCTION}

1.1 General introduction .................................

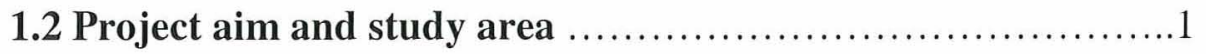

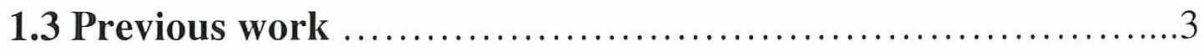

1.4 Project outline ........................................4

\section{CHAPTER 2 BACKGROUND GEOLOGY}

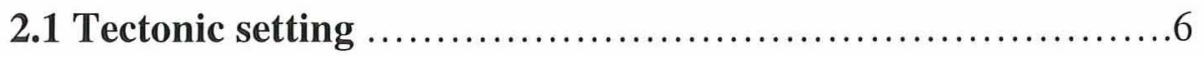

$\begin{array}{ll}\text { 2.1.1 Structural geology } & 8\end{array}$

2.2 Physiographic setting ....................................11

2.2.1 Tokomaru Marine Terrace 11

2.2.2 Loess mantled aggradation surfaces $\quad 12$

$\begin{array}{ll}2.2 .3 \text { Coastal strandplain } & 12\end{array}$

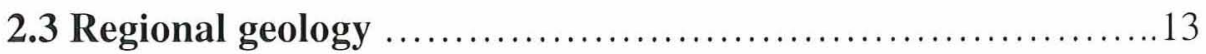

$\begin{array}{ll}2.3 .1 \text { Basement geology } & 13\end{array}$

2.3.2 Quaternary geology 15

2.3.3 Otaki Formation $\quad 17$

2.3.4 Marton, Porewa, Rata, and Ohakean Alluviums 17

2.3.5 Holocene deposits 18 


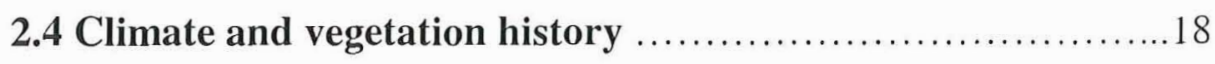

2.4.1 Vegetation in New Zealand 18

2.4.2 Records of past climate from pollen 19

2.5 Summary of background geology ....................... 19

\section{CHAPTER 3 BOREHOLE STRATIGRAPHY AND FACIES ANALYSIS}

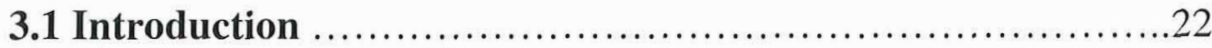

\section{LITHOSTRATIGRAPHY}

3.2 Description of borehole sequence

\section{FACIES ANAL YSIS}

3.3 Introduction to facies analysis

3.4 Description and interpretation of lithofacies ................28

3.4.1 Facies M 28

3.4.2 Facies FZS 31

3.4.3 Facies FS 34

3.4.4 Facies SL 36

3.4.5 Facies SG 37

3.4.6 Facies $S$

3.4.7 Facies IGM 39

3.4.8 Facies Z 42

3.4.9 Facies G 42

3.5 Summary of borehole stratigraphy and facies analysis ........45 


\section{CHAPTER 4 MICROFOSSIL PALEOECOLOGY}

4.1 Introduction ............................................. 46

4.1.1 Foraminiferal taphonomy $\quad 46$

4.2 Processing of foraminifera ..............................47

4.2.1 Raw data $\quad 47$

4.2.2 Species diversity 48

4.3 Cluster analysis and foraminiferal sample associations ........48

4.3.1 Sample association A 49

4.3.2 Sample association AE 56

4.3.3 Sample association AZ

4.3.4 Sample association E $\quad 57$

4.3.5 Sample association $\mathrm{N} \quad 58$

4.3.6 Sample association Q $\quad 59$

4.4 Summary and application of microfossil paleoecology ........59

\section{CHAPTER 5 CYCLOSTRATIGRAPHY}

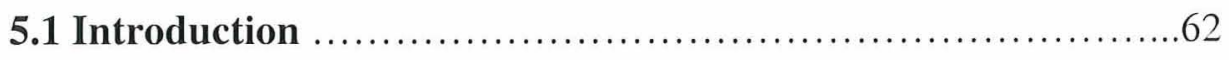

$\begin{array}{ll}\text { 5.1.1 Non-cyclostratigraphic units } & 62\end{array}$

5.2 Modern cyclostratigraphy .............................6 63

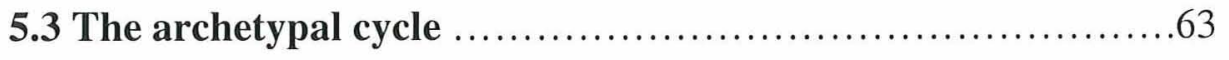

5.3.1 Cycle boundary 65

5.3.2 Transgressive systems tract 65

5.3.3 Down-lap surface $\quad 67$

5.3.4 High stand systems tract 67

5.3.5 Regressive surface of erosion 68 
5.3.6 Regressive systems tract

5.4 Cyclostratigraphy in the Levin borehole .69

5.3.1 Cycle 1

5.3.2 Cycle 2 71

5.3.3 Cycle 3 72

5.3.4 Cycle 4 72

5.4 Origin of sedimentary cycles .73

5.5 Summary of cyclostratigraphy .74

\section{CHAPTER 6 PAL YNOLOGY}

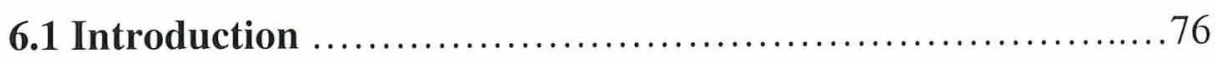

6.1.1 Sample selection and palynomorph identification 76

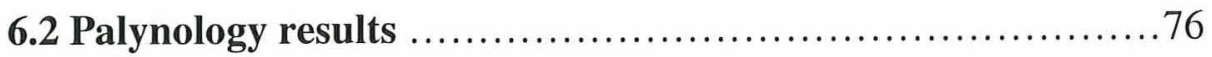

$\begin{array}{ll}\text { 6.2.1 Pollen and spore representation } & 77\end{array}$

6.2.2 Preservation of palynomorphs $\quad 80$

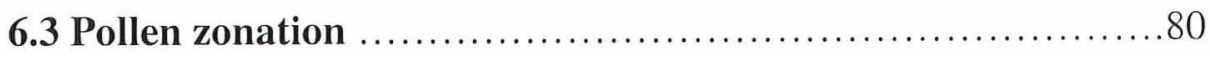

6.3.1 Problems with using relative abundances 81

6.3.2 Description of pollen zones $\quad 82$

6.4 Reconstructions of past vegetation $\ldots \ldots \ldots \ldots \ldots \ldots \ldots \ldots \ldots . \ldots 8$

6.5 Reconstruction of past climate .........................91

6.6 Summary of vegetation and climate reconstructions ...........96 


\section{CHAPTER 7 BOREHOLE CHRONOLOGY}

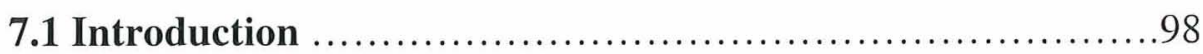

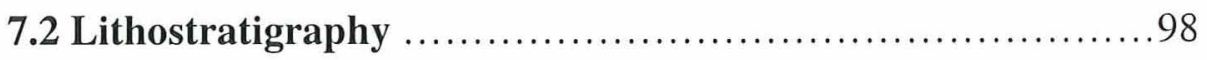

7.2.1 Ohakean Alluvium 98

$\begin{array}{ll}\text { 7.2.2 Otaki Formation } & 100\end{array}$

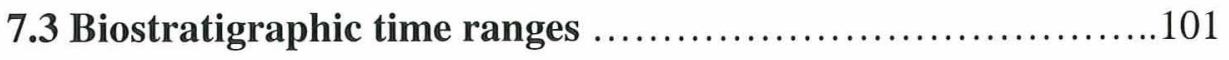

$\begin{array}{ll}\text { 7.3.1 Marine molluscs } & 101\end{array}$

$\begin{array}{ll}\text { 7.3.2 Nannofossils } & 104\end{array}$

7.4 Tephrochronology ...................................... 104

7.4.1 Unknown Tephra A (131-132m depth) 107

7.4.2 Unknown Tephra B and Middle Griffins Road Tephra

(Tephra C) (206-208m depth) 107

7.4.3 Rangitawa Tephra (Tephra D) and Lower Finnis Road Tephra

(Tephra E) (228-229m depth) 109

7.4.4 Unknown Tephras F and G (276-277m depth) 109

7.5 Integrated chronostratigraphic framework ..................111

7.5.1 Chronology and periodicity of sedimentary cycles 111

7.5.2 Chronology of Last Interglacial strata 113

$\begin{array}{ll}\text { 7.5.3 Chronology of Last Glacial strata } & 114\end{array}$

7.6 Chronology and uplift of the Levin Fault ................... 114

7.7 Summary of borehole chronology ...................... 117 


\section{CHAPTER 8 CONCLUSIONS AND PALEOENVIRONMENTAL SYNTHESIS OF THE LEVIN BOREHOLE}

8.1 Introduction 118

8.2 Paleoenvironmental synthesis of the Levin borehole 118

8.3 Concluding comments

REFERENCES $128-145$

\section{APPENDICES}

A: GRAPHIC LOG OF THE LEVIN BOREHOLE $-0-$ to $-15-$

B: MACROFOSSIL IDENTIFICATION, TAXONOMY, AND PALEOENVIRONMENTAL DETERMINATIONS FOR LEVIN BOREHOLE SAMPLES (Includes photographs). $-16-$ to $-25-$

C: GRAIN SIZE ANALYSIS AND DATA $-26-$ to $-33-$

D: Microfossil ANALYSIS AND DATA $-34-$ to $-37-$

E: Pollen analysis AND data. $-38-$ to $-40-$

F: SUMMARY OF DATES RELEVANT TO THE LEVIN BOREHOLE. $-41-$ to $-44-$

G: NANNOFOSSIL DATA $-45-$ to $-53-$

H: TEPHRA GLASS CHEMISTRY $-54-$ to $-56-$ 


\section{LIST OF FIGURES}

Figure/caption

1.1 Location of study area

1.2 Drill site and rig 5

2.1 Tectonic setting of the North Island of New Zealand 7

2.2 Structure of the South Wanganui Basin 9

2.3 Structural features of the Manawatu-Horowhenua Region $\quad 10$

2.4 Qmap geology of the Horowhenua District (after Begg and Johnston, 2000) 16

3.1 Stratigraphic column and location of litho-units and facies (inc. caption) 23

3.2 Photographs of Facies M 30

3.3 Shelf-shoreface sedimentation and ichnofacies

(after Walker and James, 1992) 32

3.4 Photographs of Facies FZS 33

3.5 Photographs of Facies FS and S 35

3.6 Photographs of Facies SL and SG 38

3.7 Determination of sub-facies Sd and Sb using textural characteristics $\quad 40$

3.8 Photographs of Facies IGM 41

3.9 Photographs of Facies Z 43

3.10 Photographs of Facies G 44

4.1 Photographs of foraminifera from Levin borehole 50-51

4.2 Dendrogram and foraminifera sample associations 52

4.3 Definitions of sample associations 53

4.4 Species diversity and stratigraphic distribution of sample associations $\quad 54$

4.5 Paleoecology of sample associations 55

4.6 Reconstructions of past environments from foraminifera and facies analysis 61

5.1 Non-cyclostratigraphic units $\quad 64$

5.2 Archetypal cycle $\quad 66$

5.3 Cyclostratigraphy of the Levin borehole $\quad 70$

5.4 Sequence stratigraphy of Wanganui Basin (after Saul et al., 1999), and origin of borehole sedimentary cycles $\quad 75$

6.1 Photographs of pollen and spores from Levin borehole (inc. caption) 78 
6.2 Percentage frequency bars graphs and pollen sum

6.3 Sums of a full pollen assemblage and one with fern spores omitted

6.4 Reconstructions of past climate

6.5 Location of glacial lowstands from pollen

94

7.1 Cross sections over the Horowhenua coastal plain (inc. caption) 99

7.2 Mollusc biostratigraphic time ranges

7.3 Late Pleistocene chronostratigraphy of Wanganui Basin (after Pillans, 1994) 103

7.4 Tephras in the Levin borehole 105

7.5 Geochemistry of sample 206-208m depth - Middle Griffins Road Tephra 108

7.6 Geochemistry of sample 228-229m depth - Rangitawa and Lower Finnis Road Tephras

7.7 Chronostratigraphy of the Levin borehole

7.8 Oxygen isotope stage 7 in the Horowhenua

7.9 Seismic section (after Aharoni, 1991)

8.1 Geologic history of the Levin area (340-20ka) 119-123 


\section{LIST OF TABLES}

Table/caption

2.1 Pleistocene river and marine terrace chronology and

$\begin{array}{ll}\text { Regional lithostratigraphy } & 14\end{array}$

2.2 History of Pleistocene vegetation change in central New Zealand 21

3.1 Borehole lithostratigraphic units $24-27$

3.2 Lithofacies and lithofacies interpretations $\quad 29$

4.1 List of foraminifera found in Levin borehole 48

6.1 List of pollen and spores found in Levin borehole $\quad 77$

6.2 Pollen zonation $\quad 82$

6.3 Summary of past vegetation and climate $\quad 97$

$\begin{array}{ll}7.1 \text { Radiocarbon dates retrieved from Levin borehole } & 100\end{array}$

7.2 Summary of Late Pleistocene tephras in Wanganui Basin 106 


\section{CHAPTER 1 \\ INTRODUCTION}

\subsection{GENERAL INTRODUCTION}

Throughout the Quaternary, large-scale variations in the Earths orbit have resulted in global cooling and warming cycles on time scales of 20ka, 40ka, and 100ka (precession, obliquity, and eccentricity) (e.g. Hays et al., 1976). Global cooling and warming cycles resulted in the waxing and waning of ice sheets and therefore changes in the volume of water in the world's oceans causing eustatic sea level to undergo large fluctuations. Manifestations of sea level fluctuations are recorded in the deep sea by the oxygen isotope record (e.g. Imbrie et al., 1984; Shackleton et al., 1990) and on continental shelves where regression and transgression of shorelines has lead to deposition of cyclic shallow marine and terrestrial sediments (e.g. Beu and Edwards, 1984; Carter et al., 1991).

New Zealand contains extensive records of Quaternary sea level due to its location on the active convergent plate boundary that has resulted in the uplift and preservation of shallow marine sediments. The sedimentary record of sea level change is well documented from cyclic shallow marine strata in Wanganui Basin in southwest North Island where slow basinal subsidence during the Plio-Pleistocene allowed some $4-5 \mathrm{~km}$ thick sedimentary sequence to accumulate (Anderton, 1981). Uplift and gradual emergence of the basin in the Rangitikei and Wanganui Regions has allowed many of these deposits to be studied in outcrops (e.g. Abbott and Carter, 1994; Naish and Kamp, 1997a).

\subsection{ProjeCt AIM AND STUDY AREA}

The aim of this project is to investigate how climate and sea level changes have affected sedimentation on a coastal margin in southwest North Island of New Zealand. The study area is located in the north Horowhenua District between the Ohau and Manawatu Rivers and the Tararua Range and Tasman Sea in the vicinity of Levin Township (Fig. $1.1)$. 


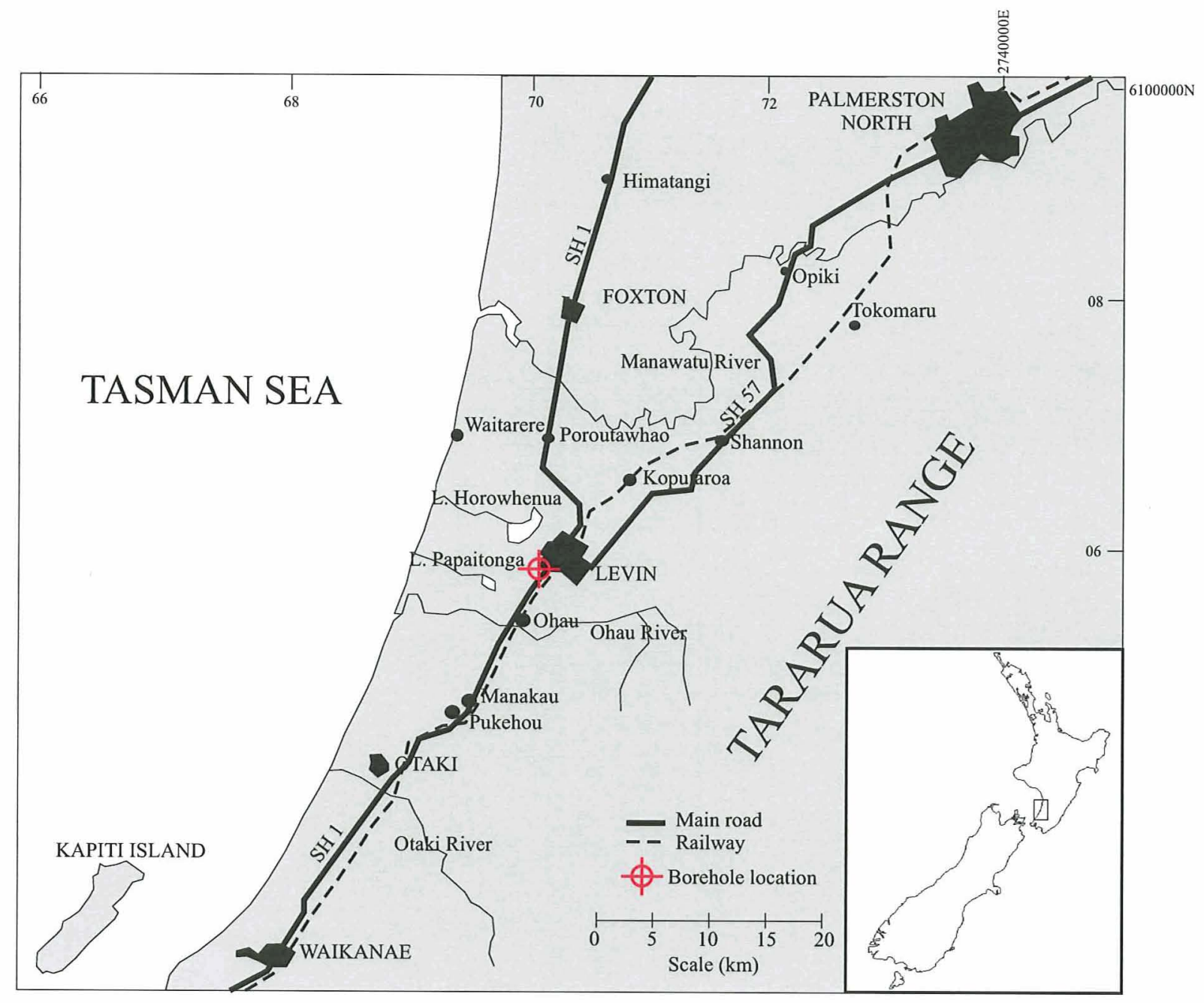

Figure 1.1: Location of the study area, north Horowhenua District, SW North Island, New Zealand. The Levin borehole is located in south Levin near State Highway One. 
The north Horowhenua is ideally suited to study the sedimentary record of sea level change as smooth subsidence and large sediment supply has resulted in a near continuous record of strata (e.g. Rich, 1959). Climate and sea level change are studied from a c. $280 \mathrm{~m}$ deep borehole drilled on the southern outskirts of Levin (GR 2701700 6061200 ) using various techniques such as facies analysis, microfossil paleoecology, cyclostratigraphy, and palynology that will allow strata to be described in terms of glacio-eustatic cycles.

\subsection{PREVIOUS WORK}

Adkin (1910) and Cotton (1918) provided the first description of the evolution of the Horowhenua District based on regional geomorphic mapping. Adkin (1910) documented the Post Tertiary progradation and retrogradation of the Ohau River fan in response to vertical movements of the land. Cotton (1919) described the coastal marine terrace as building up through successive stages of retrogradation, caused by increased wave erosion and sea cliff formation, and progradation that was related to low wave energy and alluvial fan and strandplain development. It was not until the 1950's, when tectonism and sea level change were described as working concurrently, that shallow marine sediment began to be studied in terms of relative sea level change. Fleming (1953) recognised that numerous deposits in the Wanganui Basin formed cyclic sedimentary packages and speculated that tectonic subsidence had controlled sea level changes, which resulted in the sedimentation of recurring lithologies. Recent stratigraphic studies in Wanganui Basin have shown glacio-eustacy to be the main influence on cyclic sedimentation (Carter et al., 1991; Pillans, 1994; Abbott and Carter, 1994; Naish and Kamp, 1997a). However, south of Wanganui Basin in the Horowhenua, only strata correlative with the Last Interglacial Period has been studied in any detail due to lack of outcrops (Oliver, 1948; Palmer et al., 1988; Sewell, 1991). The deep borehole, which is analysed in this study, provided the first means to studying a longer history of climate and sea level change in the Horowhenua. 


\subsection{PROJECT OUTLINE}

Drilling was undertaken by N. Webb and Sons Drilling Limited (Levin) between October 2003 and April 2004. The borehole was drilled using a cable-tool percussion drilling rig (Fig. 1.2). Unconsolidated sediment was retrieved after each metre of penetration using a metal bailer that contains a one-way valve at one end. Metal casing was added after every few metres to prevent collapse. Samples were collected from the bailer when a change in lithology occurred and from regular intervals within thick sedimentary units. In total, 70 samples were collected that are shown on the borelog (App. A).

Initially the borehole strata were subdivided into informal lithostratigraphic units and described using facies analysis, providing information regarding depositional environments (Chapter 3). Grainsize analysis assisted in the definition of facies and interpreting these in terms of comparative water depth (e.g. Dunbar and Barrett, 2005) (methods outlined in App. C). Paleoecological investigations of microfossils (methods in App. D) were used to refine the interpretations from facies analysis by providing additional paleoenvironmental information for marine sedimentary units (Chapter 4). The vertical associations of facies developed in Chapter 3 and 4 were studied using cyclostratigraphy, which related strata to the cycle of relative sea level change (Chapter 5). A chronostratigraphy for the borehole sequence was defined using palynology (methods outlined in App. E), and a range of absolute and relative methods such as nannofossil biostratigraphy (App. G) and tephrochronology (App. H), which placed strata in the context of the oxygen isotope record from marine cores (Chapter 7). This thesis concludes with an interpretation of the geologic history for the Levin area from the borehole in terms of variations in eustacy, climate, sediment supply, and tectonism (Chapter 8). 


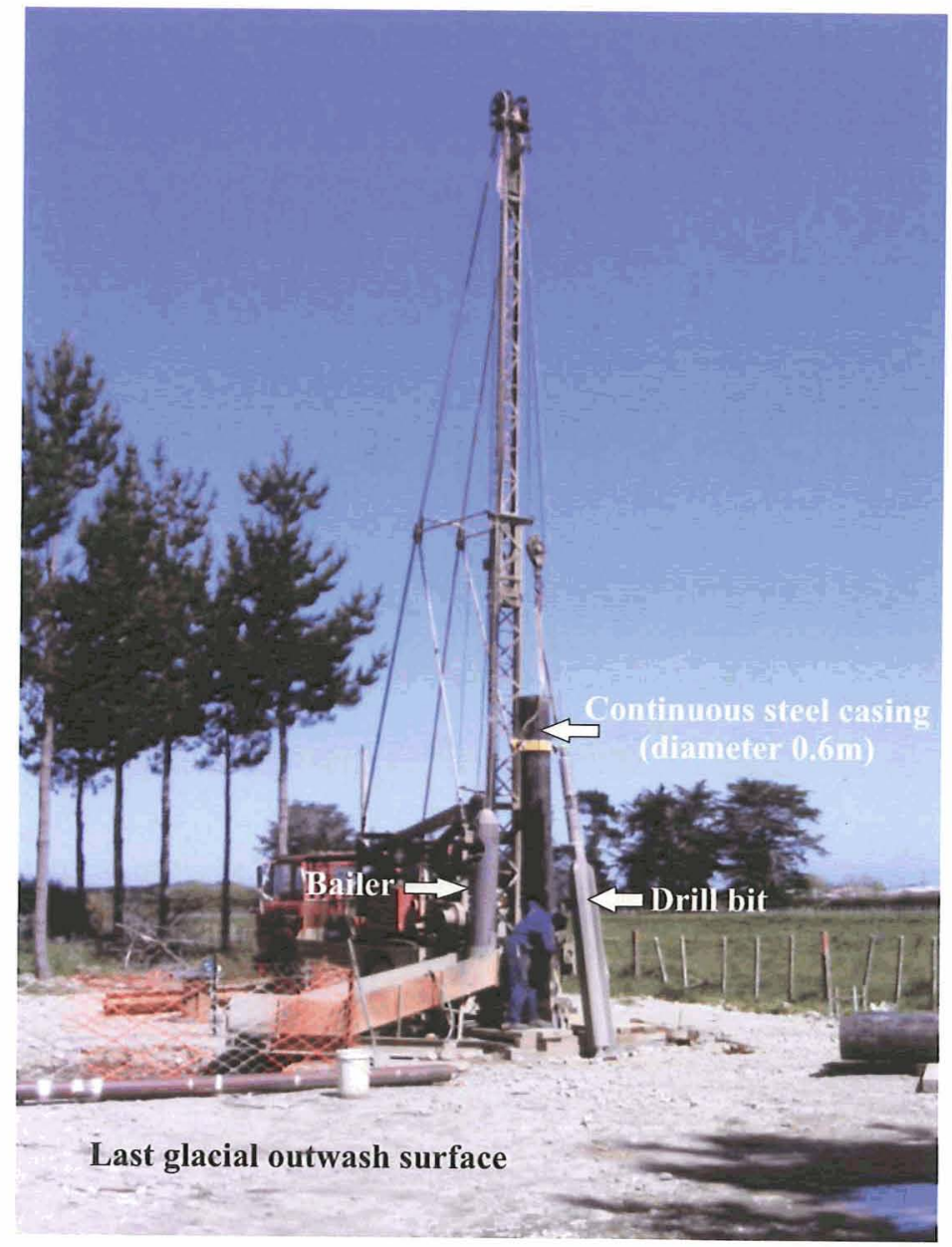

Figure 1.2: Outline of cable-tool drilling and photograph of drill site looking west from Levin. 


\section{CHAPTER 2 \\ BACKGROUND GEOLOGY}

\subsection{TeCTONIC SETTING}

The Horowhenua District straddles the boundary between the uplifting Tararua Range and the subsiding South Wanganui Basin (Fig. 2.1). This region has formed adjacent to a convergent plate boundary, where the Australian Plate is being under-thrust from the east by the Pacific Plate at about $40 \mathrm{~mm} / \mathrm{yr}^{-1}$ (Fig. 2.1) (Walcott, 1978), and as a consequence is undergoing crustal shortening and deformation (Cole and Lewis, 1981).

The South Wanganui Basin (SWB) is a back-arc sedimentary basin located in central New Zealand, which extends from the Marlborough Sounds to the Central Volcanic Region and from the North Island axial ranges to the South Taranaki Basin (Fig. 2.2). Subsidence within the basin initiated during the Pliocene due to frictional shear exerted by slab-pull forces between the Pacific and Australian Plates causing the overriding Australian Plate to flex beneath Wanganui (Stern et al., 1992). During the Quaternary, rates of sedimentation roughly matched that of subsidence in the basin allowing some 4$5 \mathrm{~km}$ thick mostly shallow marine sediment to accumulate (Anderton, 1981). Gradual emergence of the basin to the north during the Pleistocene has produced a $4-6^{\circ}$ southward regional tilt of basin strata and caused the basins depocentre to migrate slowly south (Anderton, 1981).

The Tararua Range forms the southern segment of the North Island axial tectonic range. Uplifting of the ranges resulted from the northwest tilting of blocks of basement greywacke in the last c.3.7Ma as a result of ramping of the subducting Pacific Plate (Neef, 1999). Uplift rates within the range have been estimated from a broad concordance of summit heights that resemble a Tertiary peneplain surface (Wellman, 1948). By assuming a single age of the surface, and that uplift occurred synchronously, Ghani (1978) estimated an average uplift rate of $1.3 \mathrm{~mm} / \mathrm{yr}^{-1}$, with rates of $6.5 \mathrm{~mm} / \mathrm{yr}^{-1}$ occurring locally. 


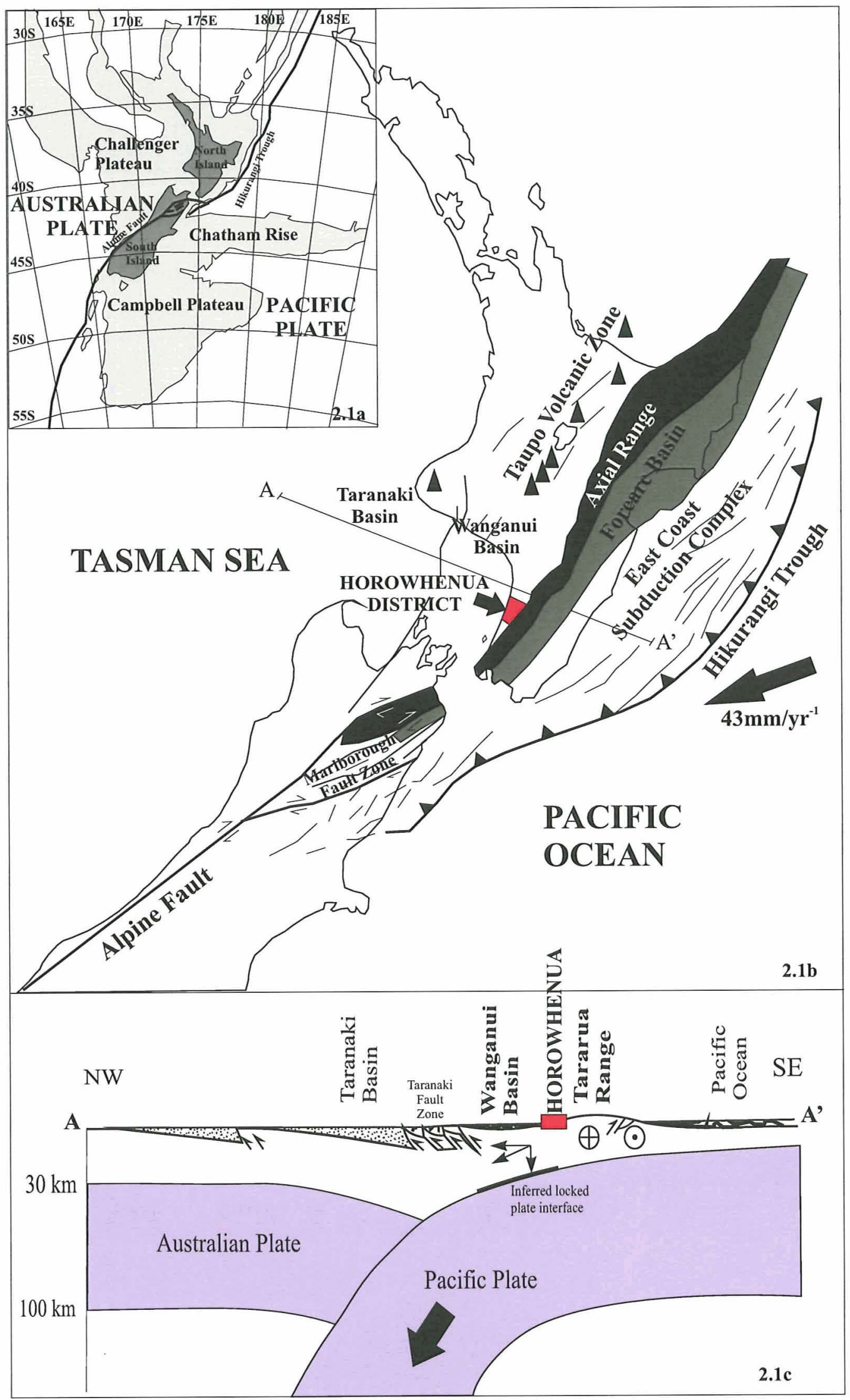

Fig. 2.1: Tectonic setting of the North Island of New Zealand. (2.1a) Position of New Zealand relative to the Pacific-Australain plate boundary (Walcott, 1978). (2.1b) Tectonic provinces of the North Island based on Cole and Lewis (1981). (2.1 c) Cross section view of line A-A' showing Wanganui Basin and Tararua Range relationship to the plate boundary at depth, based on an offshore seismic survey from Stern et al. (1992). 
The Horowhenua District is uplifting at around $0.3 \mathrm{~mm} / \mathrm{yr}^{-1}$ as indicated by estuarine deposits dated at $6330 \pm 70 \mathrm{yrs}$ BP now found $0.9-1.1 \mathrm{~m}$ above present sea level near Shannon (Shepherd, 1987) (Fig. 1.1). Uplift rates of 0.25 and $0.35 \mathrm{~mm} / \mathrm{yr}^{-1}$ have also been calculated from a Last Interglacial marine terrace near Levin and Koputaroa, which now lie 30-40m above present sea level (Hesp and Shepherd, 1978). Subsidence is occurring in the Lower Manawatu Valley at around $1.0-1.1 \mathrm{~mm} / \mathrm{yr}^{-1}$ as indicated by early Holocene marine deposits now found $5.6 \mathrm{~m}$ below present sea level at Opiki (Gibb, 1983).

\subsubsection{Structural geology}

Early oil exploration seismic reflection surveys have revealed a complex pattern of NNE trending structural basement faults within the SWB that have been interpreted as primary wrench faults related to basin development (Fig 2.2) (Anderton, 1981). Above certain faults, sediments have been draped across scarps producing anticlines and synclines, some of which appear to still be growing (Te Punga, 1957; Rich, 1959) (Fig. 2.3). In the Manawatu Region, anticlines occur at Marton, Mt Stewart-Halcombe, Fielding, Pohangina, Oroua (Te Punga, 1957), and Himatangi (Rich, 1959) (Fig. 2.3). Anderton (1981) suggests these anticlines are Late Pleistocene in age as no Castlecliffian Strata has been folded. Structural depressions have developed between the basement highs, such as the Kairanga Trough, which are now filled with sediment (Rich, 1959). In the Horowhenua District, two anticlines occur at Levin and Shannon that are separated by the Koputaroa syncline (Te Punga, 1957; Hesp, 1975) (Fig. 2.3). The Levin and Shannon anticlines are considered to be of 'extreme youth' as only Haweran Series strata has been folded (Te Punga, 1954a). An age of at least 60ka has been estimated for the Levin Anticline based on minimum local uplift rates of $0.35 \mathrm{~m} / \mathrm{ka}$ (Hesp and Shepherd, 1978). Older basement thrusts occur at greater depths which have no surface expression. 


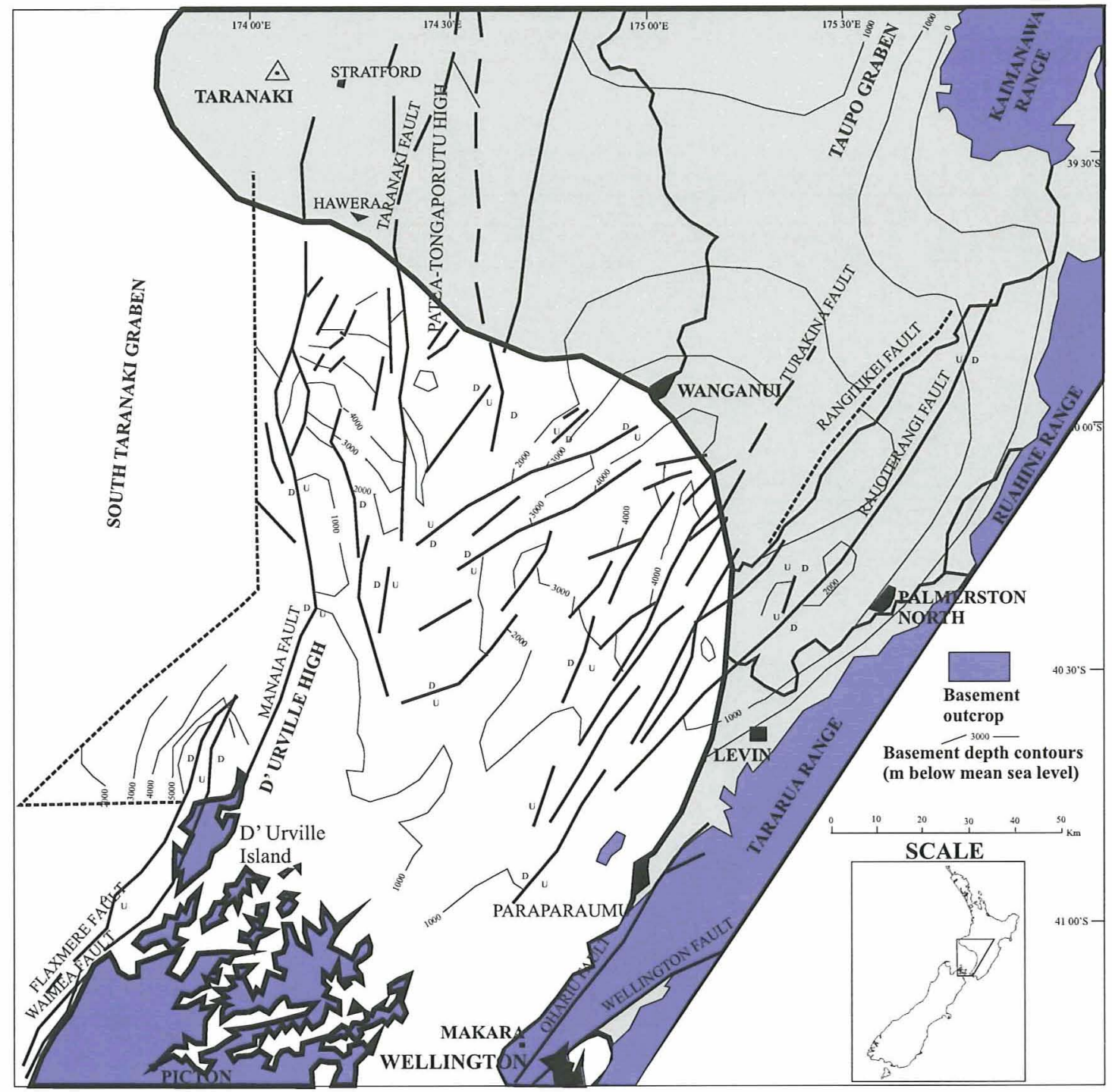

Fig. 2.2: Map of Southwest North Island showing tectonic structure of the South

Wanganui Basin and distribution of basement contours (after Anderton, 1981). 


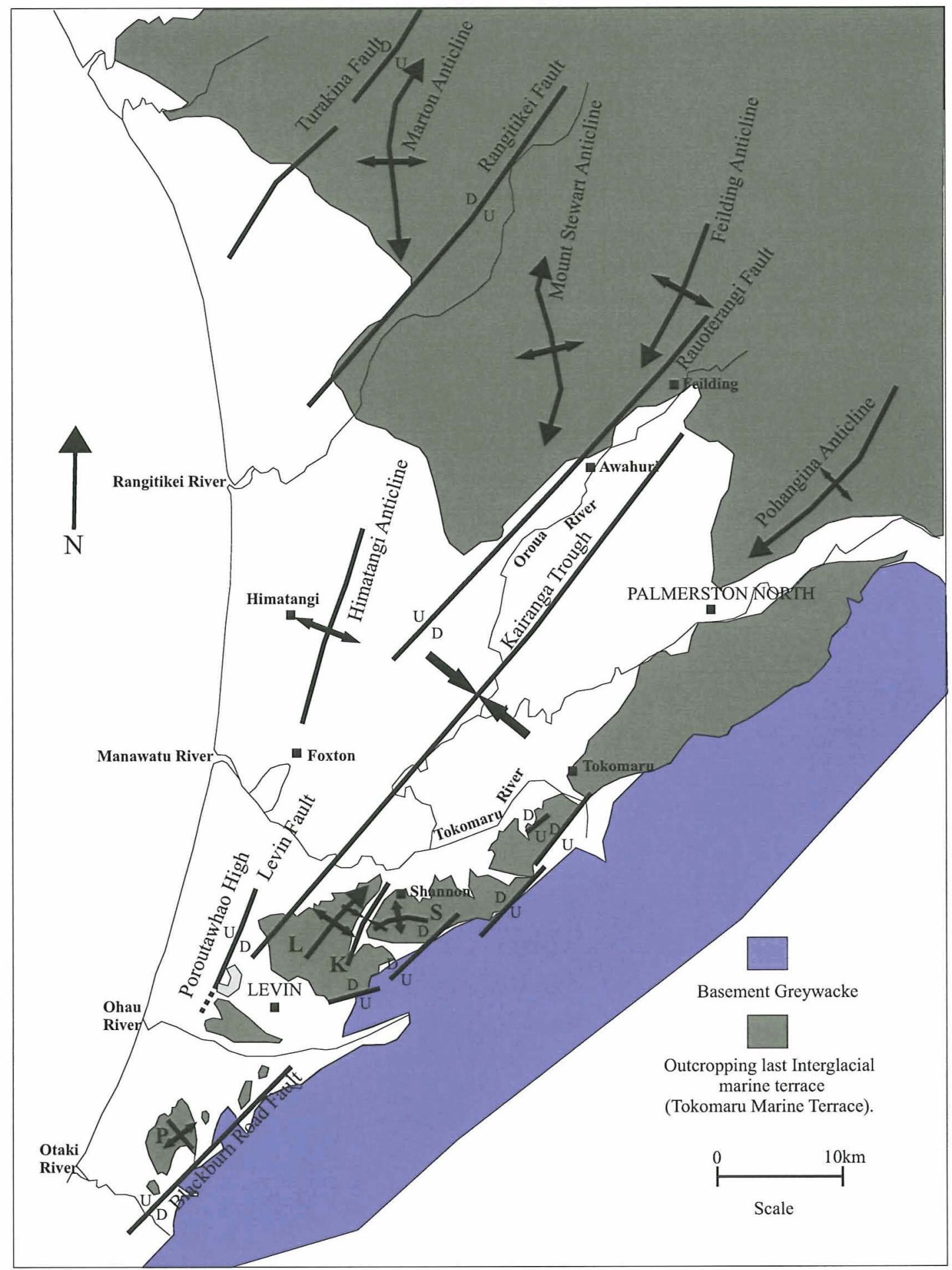

Fig. 2.3: Main structural features of the Manawatu-Horowhenua Region west of the axial ranges (Te Punga, 1957; Rich, 1959; Hesp, 1975). 
Bekesi (1989) used geophysics to map what is thought to be the southern continuation of the Poroutawhao High, a wave cut greywacke platform found near present sea level in the Horowhenua (Te Punga, 1954a). The eastern margin of the Poroutawhao High is marked by the Levin Fault, which bounds the western margin of the Kairanga Trough in the Horowhenua (Aharoni, 1991) (Fig. 2.3). During the Pleistocene, basement highs and anticlines may have affected sedimentation in the lower Manawatu Valley by controlling the course of the Manawatu River or acting as coastal barriers during transgressions (Rich, 1959). It is thought during the Post glacial transgression (11-7ka ago; Gibb, 1986), estuarine conditions prevailed within the Kairanga Trough, which was sheltered behind the Poroutawhao High and Himatangi Anticline (Rich, 1959; Hesp and Shepherd, 1978). A similar situation may have occurred during the last interglacial transgression, which formed a marine terrace further inland (Sewell, 1991).

\subsection{PhySIOGRAPHIC SETTING}

Three main physiographic features dominate the coastal plain in the North Horowhenua District; an uplifted partially dissected marine terrace, loess mantled fluvial aggradation surfaces, and a coastal strandplain.

\subsubsection{Tokomaru Marine Terrace}

An uplifted, partially dissected marine terrace, known as the Tokomaru Marine Terrace, borders the western flanks of the Tararua Range (Fig. 2.3). It rises from 30-40m above present sea level near Levin to approximately 90m near Palmerston North, and can be traced as far south as Otaki (Hesp and Shepherd, 1978). The terrace is backed by an old sea cliff, which truncates both river gravels and basement greywacke, and its seaward side comprises uplifted marine benches whose margins contain flat, steep sided valleys (Cotton, 1918; Hesp and Shepherd, 1978). Palmer et al. (1988) has correlated the Tokomaru Marine Terrace with the Rapanui strandline in the South Taranaki-Wanganui Regions, which has been dated at 120ka BP (OIS 5e) using amino acids (Pillans, 1983). 


\subsubsection{Loess mantled aggradation surfaces}

Loess mantled river aggradation surfaces associated with the Ohau and Otaki Rivers fan out westward from the Tararua Range bisecting older marine terraces and leaving remnant patches now preserved on the flanks of the Tararua Range. These surfaces formed during cold periods when a periglacial climate existed over much of the Tararua Range (Vella, 1963). During these times, mountain vegetation was reduced, solifluction was widespread, and streams and rivers, overloaded with sediment, aggraded their beds (Fleming, 1972). At the same time eustatic sea level was significantly lower than present (Gibb, 1986) and gravel surfaces plunged to a shoreline in Cook Strait, many of which coalesced forming extensive floodplains. Wind managed to sweep up fine silt from these floodplains and deposited it inland as loess (Cowie, 1964).

An extensive sequence of aggradation terraces has been recognised in the Rangitikei Valley (Milne, 1973), and a detailed chronology of these has been created using loess stratigraphy (Milne and Smalley, 1979) (Table. 2.1). The most extensive terrace in the Horowhenua has been correlated with the Ohakean Terrace, which is dated at $25.5 \mathrm{ka}$ (Barnett, 1984) (Fig. 2.4). Older surfaces in the Horowhenua, which are commonly more weathered and incomplete and contain multiple loess units, are correlative with Ratan, Porewan, and Marton surfaces in the Rangitikei Valley (Barnett, 1984). The Ratan (30-50ka) and Porewan (70-80ka) surfaces are less extensive and developed during cold stadial periods of the Otiran Glaciation (OIS 3 and 4) (Table. 2.1; Fig. 2.4). They contain a single loess unit derived from the Ohakean surface. The Marton surface (140-170ka) formed during the penultimate glacial period (OIS 6) as it contains three loess units derived from the Ohakean, Ratan, and Porewan Surfaces (Palmer et al., 1988). The Burnand (180ka) and Aldworth (230-240ka) surfaces have also been recognised as incomplete sections east of Otaki (Barnett, 1984) (Fig. 2.4).

\subsubsection{Coastal strandplain}

West of Levin and the uplifted terraces, a c. $6 \mathrm{~km}$ wide strandplain have developed from coastal progradation since $6 \mathrm{ka}$ ago (i.e. Gibb, 1986). Its formation has been characterised by three distinct dune building phases distinguished by varying stages of 
soil development. They are the Waitarere, Motuiti, and Foxton phases, in order of increasing age (Cowie, 1963) (Table. 2.1). The advance of the Waitarere and Motuiti phases have been partially attributed to the destruction of previously stable fore-dunes further north following the arrival of Europeans and Maori (Cowie, 1963). The oldest of the Holocene dunes, the Foxton Phase, are the most extensive forming large parabolic dunes, aligned roughly NW-SE, which reach up to $16 \mathrm{~km}$ inland. The Foxton phase is thought to have initiated at the coast about 5.5-6 ka ago from rapid onshore transport of sediment following the post-glacial transgression (Shepherd, 1987).

A fourth dune phase, the Koputaroa phase, which mantles the Tokomaru Marine Terrace and older aggradation surfaces, has been mapped near Koputaroa and Levin (Cowie, 1963). Near Levin, Koputaroa dune sand is interbedded with peat containing pollen, indicative of a cool climate and dated at $35000 \pm 1700$ yrs BP (Fleming, 1972). Analyses of roundness and heavy mineral content suggest a marine source for these dunes and they probably developed from the remobilisation of transgressive and/or regressive sands deposited upon the inner continental shelf during OIS 3 when sea level rose to less than $45 \mathrm{~m}$ below the present level (Shepherd, 1985).

\subsection{REGIONAL GEOLOGY}

\subsubsection{Basement geology}

Basement geology in the Manawatu Region has been determined from oil exploration wells drilled at Mt Stewart and Marton, which encountered basement at 1024 and 2085m depth respectively (Anderton, 1981). The rocks were similar to the Torlesse Terrane that outcrops along the axial ranges, which comprises indurated greywacke and argillite with minor amounts of mudstone, conglomerate, basalt, chert, and limestone (Foley et al., 1988). 
Table 2.1: Summary of Late Pleistocene river and marine terrace chronology, and regional lithostratigraphy

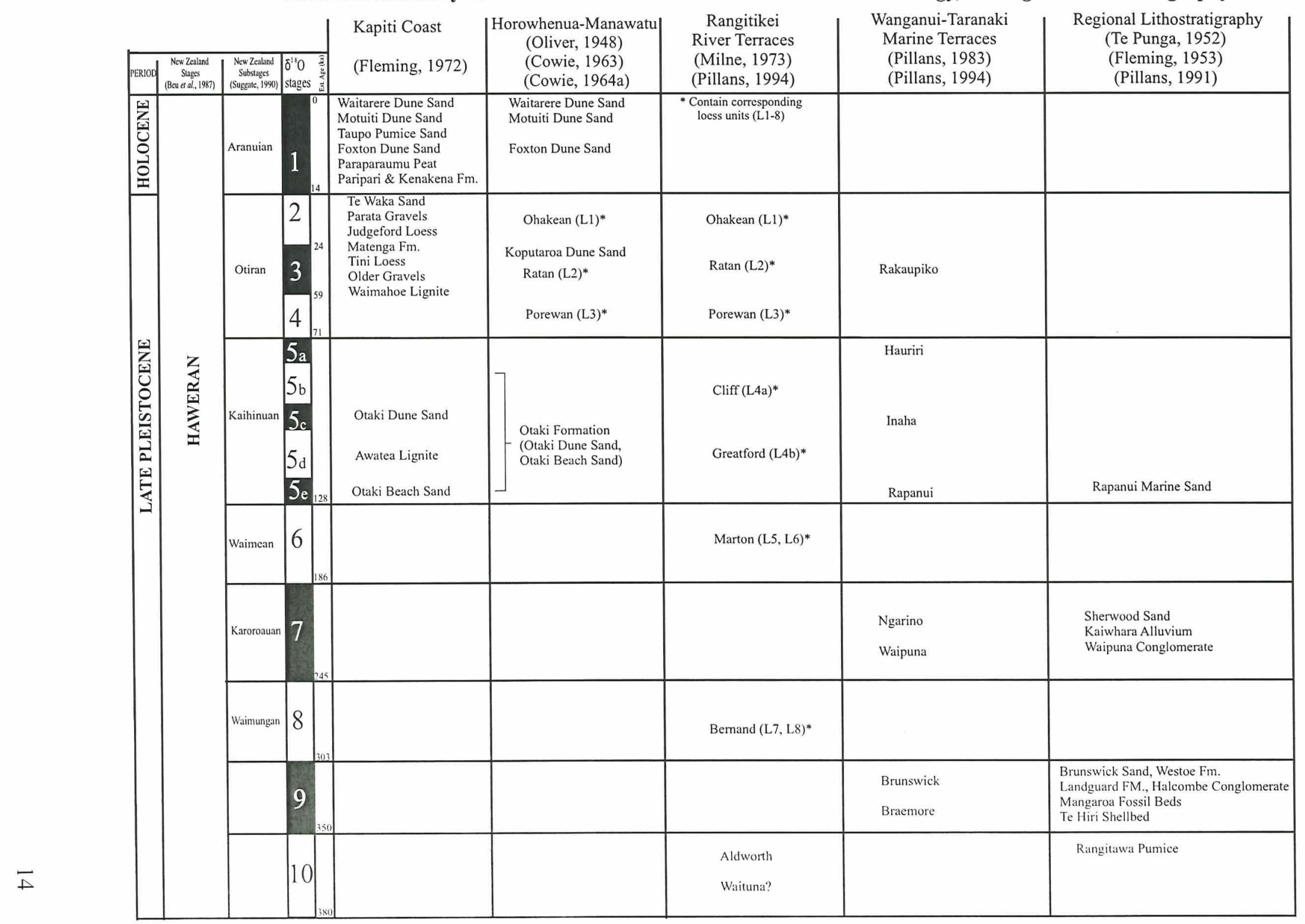


The oldest Cenozoic sediments within the South Wanganui Basin are small Oligocene faulted outliers located at Otaihanga (McPherson, 1948) and Makara (Grant-Taylor and Hornibrook, 1964) (Fig. 2.2). These consist of sandstone and thin mudstone bands interbedded with greensand, and probably represent an ancient sediment cover that predated evolution of the SWB and axial ranges (Anderton, 1981).

\subsubsection{Quaternary geology}

Sea level fluctuations have had the biggest influence on sedimentation in the SWB depositing successions of shallow marine and terrestrial sediments during interglacial and glacial periods, most of which have been grouped into the upper Wanganui Series based on biostratigraphy (5.28Ma to present) (Fleming, 1953; Beu and Edwards, 1984). The Nukumaruan (2.4-1.71Ma) and Castlecliffian (1.71-0.43Ma) Stages are represented by 47 superimposed marine cyclothems, which developed from glacioeustatic fluctuations on the paleo New Zealand shelf (Carter et al., 1991; Abbott and Carter, 1994; Naish and Kamp, 1997a). The younger Haweran Stage (0.34-0.01Ma) is represented by a flight of 13 marine terraces which developed from glacioeustatic fluctuations over a coevally uplifting shoreline (Pillans, 1983; Pillans, 1994) (Table 2.1). No sediments older than the Castlecliffian Stage can be traced south into the Horowhenua where geology consists of predominantly latest Pleistocene or younger paralic, fluvial, and peat deposits (Fleming, 1972; Sewell, 1991).

The oldest sediments exposed in the Horowhenua are gravels preserved on the western flanks of the Tararua Range east of Levin within the Makahika, Maharetu, and Blackwater Streams and Ohau and Otaki River valleys (Fig. 2.4). The gravels consist of poorly to moderately sorted clasts that contain thick weathering rinds and some have been deeply weathered to a bright rosy red colour and are extremely soft (Begg and Johnston, 2000) (Table 2.1). 


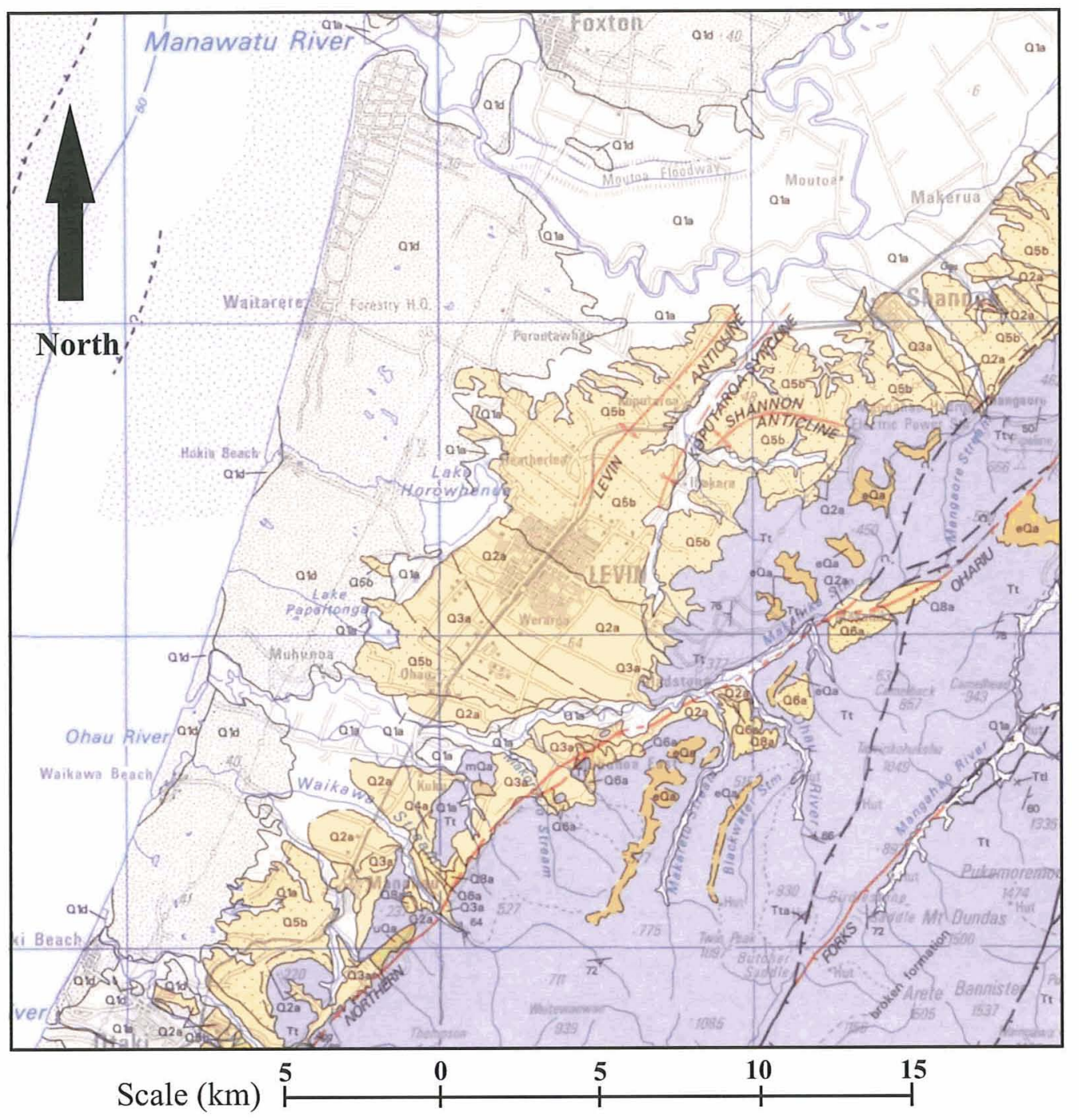

\begin{tabular}{|c|c|c|c|c|}
\hline \multirow[b]{2}{*}{ Holocene } & \multicolumn{3}{|c|}{$\begin{array}{l}\text { REGIONAL STRATIGRAPHY } \\
\text { (refer to Table 2.1) }\end{array}$} & \\
\hline & 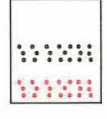 & $\begin{array}{l}\text { Q1a } \\
\text { Q1d } \\
\text { Q1b }\end{array}$ & $\begin{array}{l}\text { Well sorted flood plain gravels } \\
\text { Aeolian dunes } \\
\text { Beach deposits consisting of marine }\end{array}$ & \\
\hline \multirow{4}{*}{ Pleistocene- } & & $\begin{array}{l}\text { Q2a } \\
\text { Q3a } \\
\text { Q4a }\end{array}$ & $\begin{array}{l}\text { gravel with sand, mud, and beach ridges } \\
\text { Poorly to moderately sorted gravel with } \\
\text { minor sand or silt underlying aggradational } \\
\text { or degradational terraces (includes fan gravel) } \\
\text { (correlative Ohakean, Ratan, Porewan Surfaces) }\end{array}$ & Structural geology \\
\hline & & Q5b & $\begin{array}{l}\text { Beach deposits consisting of marine gravel } \\
\text { with sand, commonly underlying loess and } \\
\text { fan deposits (correlative Tokomaru Marine Terrace) }\end{array}$ & $\begin{array}{c}\text { Thrust } \\
\text { fault }\end{array}$ \\
\hline & 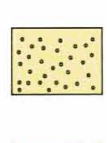 & $\begin{array}{l}\text { Q6a } \\
\text { Q8a }\end{array}$ & $\begin{array}{l}\text { Weathered, poorly to moderately sorted gravel } \\
\text { underlying loess covered, commonly eroded } \\
\text { aggradational surfaces (correlative Marton, Burnand, } \\
\text { Aldworth Surfaces). }\end{array}$ & $\begin{array}{c}\text { Fault } \\
\text { Black: inactive Red: active } \\
+\end{array}$ \\
\hline & & $\begin{array}{l}\text { mQa } \\
\text { uQa } \\
\text { eQa }\end{array}$ & $\begin{array}{l}\text { Undifferentiated weathered, poorly sorted loess } \\
\text { covered fan deposits (mQa), alluvial gravel deposits } \\
\text { (uQa) and lacustrine silt deposits (eQa). }\end{array}$ & 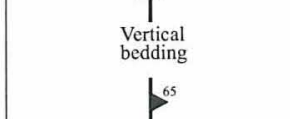 \\
\hline $\begin{array}{l}\text { Triassic- } \\
\text { Jurassic }\end{array}$ & & $\mathrm{Tt}$ & $\begin{array}{l}\text { Torlesse Supergroup: Rakaia Terrane Grey } \\
\text { sandstone-mudstone sequences and poorly bedded } \\
\text { sandstone with minor coloured mudstone, } \\
\text { conglomerate, basalt, chert, and rare limestone }\end{array}$ & $\left.\right|_{\text {Bedding }} ^{\text {Foliation }}$ \\
\hline
\end{tabular}




\subsubsection{Otaki Formation}

The Otaki Formation is the name given to marine sediment in the Horowhenua District deposited during the Last Interglacial Period (80-120ka ago) (Oliver, 1948). The formation commonly outcrops along the western side of the Tokomaru Marine Terrace near Forest Lakes, Ohau, Levin, and Shannon (Fig. 2.4), and has also been encountered at shallow depths within boreholes west of the terrace (Bekesi, pers. comm., 2004).

Three distinct lithological units characterise the formation: 1) basal beach gravelly-sand (Otaki Beach Sand); 2) a thin lignite band (Awatea Lignite); and, 3) an overlying dune sand (Otaki Dune Sand). According to Fleming (1972) the gravelly beach sand represents deposition during a transgressive sea level highstand, which inundated the coastal plain during the Last Interglacial Period. The overlying dune sands represent beach derived littoral deposits that deposited when the sea advanced, and the lignite was deposited in swamps impeded by the dunes (Table 2.1).

Sewell (1991), who mapped and described the Otaki Formation at various localities throughout the Horowhenua, found a gradual change in marine sedimentation accompanied deposition from a wave-dominated depositional environment near Forest Lakes, through mixed wave-tide near Ohau and Levin, to a tide-dominated depositional environment near Shannon. From bore log data, Sewell (1991) estimated the thickness of the Otaki Formation ranges from between 20-35m that thickens to the west.

\subsubsection{Marton, Porewa, Rata, and Ohakean Alluvium}

The Marton, Porewa, Rata, and Ohakean Alluviums refer to gravel deposits forming fluvial terraces in the Horowhenua (Barnett, 1984) (Table 2.1; Fig. 2.4). The alluviums are generally composed of coarse, poorly sorted clasts, with a greyish light brown sandy matrix and commonly lack wood or carbonaceous material as vegetation was probably sparse and not woody (Fleming, 1972; Barnett, 1984). However, the terraces occasionally preserve thin lenses of carbonaceous silt representing swampy deposits later buried by growing fans (Fleming, 1970). 


\subsubsection{Holocene deposits}

Early Holocene (OIS 1) fluvial and estuarine deposits underlie the Manawatu Region at shallow depths east of Levin (Hesp and Shepherd, 1978; Shepherd, 1987) (Fig. 2.4). At least $11 \mathrm{~m}$ of thinly bedded silty sand and mud, which contain estuarine dwelling molluscs, have been encountered within boreholes near the Koputaroa-Levin Highway (Hesp and Shepherd, 1978). The shells are thought to have lived in an extreme marginal low salinity environment, possibly in the upper reaches of an estuary, which occupied the lower Manawatu Valley during the postglacial transgression (Hesp and Shepherd, 1978). During the middle to late Holocene, the former estuary has infilled with phases of fluvial then dune sand deposits, which are considered to be time-transgressive (Shepherd, 1987).

\subsection{Climate AND VEgETATION HISTORY}

\subsubsection{Vegetation in New Zealand}

New Zealand geographic isolation for most of the Cenozoic favours a high percentage of endemic tree species, which are characterised by an ancient southern flora of podocarps and southern beeches (Dawson, 1988). Presently, two broad categories of forests dominate in New Zealand; conifer broad-leaved and beech.

Conifer broad leaved forests are multi-storied and structurally complex. They may contain up to 5 layers consisting of a podocarp canopy, reaching 30-40m above ground level, over a lower canopy dominated by angiosperms, reaching c. $25 \mathrm{~m}$ altitude. Beneath the canopy lies a sub-canopy of small trees and tree ferns, a shrub layer, and a ground layer. Conifer broad leaved forests can occupy a range of climatic extremes; however, they are often most complex within warm, fertile lowland sites (Dawson, 2000).

Beech forests consists of Nothofagus trees (N. menziesii, N. fusca, N. truncata, and N. solandri) and are generally less diffuse with fewer species than conifer broad leaved forests. However, Nothofagus trees may become intergraded with broad-leaved conifers to form mixed forests at intermediate elevations (Dawson, 1988). Beech forests form 
higher tree lines than conifer broad leaved forests, on generally cooler, drier, and less fertile landscapes such as on the sides of mountain ranges (Dawson, 2000).

\subsubsection{Records of past climate from pollen}

In southwest North Island, pollen sequences taken from ancient terrestrial and marine strata record only a small proportion of a single glacial-interglacial cycles for the Pleistocene (e.g. Bussell, 1986; Pillans et al., 1988; Bussell, 1990; Bussell, 1993; McGlone et al., 1984; Bussell and Pillans, 1997) (Table 2.2). Pollen sequences representing interglacial periods occur at Inaha in South Taranaki (McGlone et al., 1984), Rapanui near Wanganui (Harris, 1953), Levin (Mildenhall, 1991), Pauatahanui (Mildenhall, 1979), and on the Wellington Peninsula (Mildenhall, 1994). These records show interglacial periods generally produced vegetation similar to the present day, which were characterised by fully developed, structurally complex conifer broad leaved forests dominated by diverse podocarps, small trees, herbs, and shrubs. Also during interglacials, beech forests occupied less favourable growing sites on upland mountainous areas, and at intermediate elevations podocarps and beech trees grew together producing mixed forests. Frost sensitive plants such as Ascarina lucida were also most abundant during interglacial periods (McGlone and Moore, 1977).

Pollen sequences indicative of glacial periods occur at Inaha (McGlone et al., 1984), Rangitawa near Wanganui (Bussell, 1986), Koputaroa near Levin (McIntyre, 1963), Lindale near Otaki (McIntyre, 1970), and on the Wellington Peninsula (Mildenhall, 1994). These records show glacial periods generally produce sparsely vegetated landscapes dominated by grassland-scrubland with a near complete absence of typical lowland vegetation (McGlone et al., 1984; Bussell, 1986). Forests which were present were less diverse than during interglacial periods and were dominated by Nothofagusgroup trees (McIntyre, 1963; McIntyre, 1970; Pocknall, 1984).

\subsection{SUMMARY OF BACKGROUND GEOLOGY}

In summary, the study area located in the north Horowhenua District lays adjacent to the Tararua Range and South Wanganui Basin, which are located on the back-arc of an 
active convergent plate boundary. High tectonic stresses associated with the convergence have caused basement geology to be faulted and folded into series of broad NNE trending highs and troughs. The troughs have infilled with alternating marine and terrestrial strata, which reflect Quaternary climate and glacioeustatic fluctuations. An example of this is the Kairanga Trough, where some $700 \mathrm{~m}$ thick sedimentary strata have accumulated near Ohau. Basement highs may have also affected sedimentation by controlling the courses of rivers or acting as barriers during transgressions. In the Horowhenua, the surface geology is young, predominantly $<200 \mathrm{ka}$ old, and comprises mainly shallow marine and fluvial terrace deposits. Pollen contained in terrace deposits throughout the Manawatu, Wanganui, and Taranaki Regions record brief glimpses of climate during the Pleistocene. These pollen records show interglacial periods produced vegetation that were characterised by structurally complex conifer broad leaved forests, which indicated warm and moist climate. By contrast, glacial periods produced beech forests and scrubland-grassland vegetation that indicated climate was cooler and wetter than the present day. 
Table 2.2: History of Pleistocene vegetation change in central New Zealand.

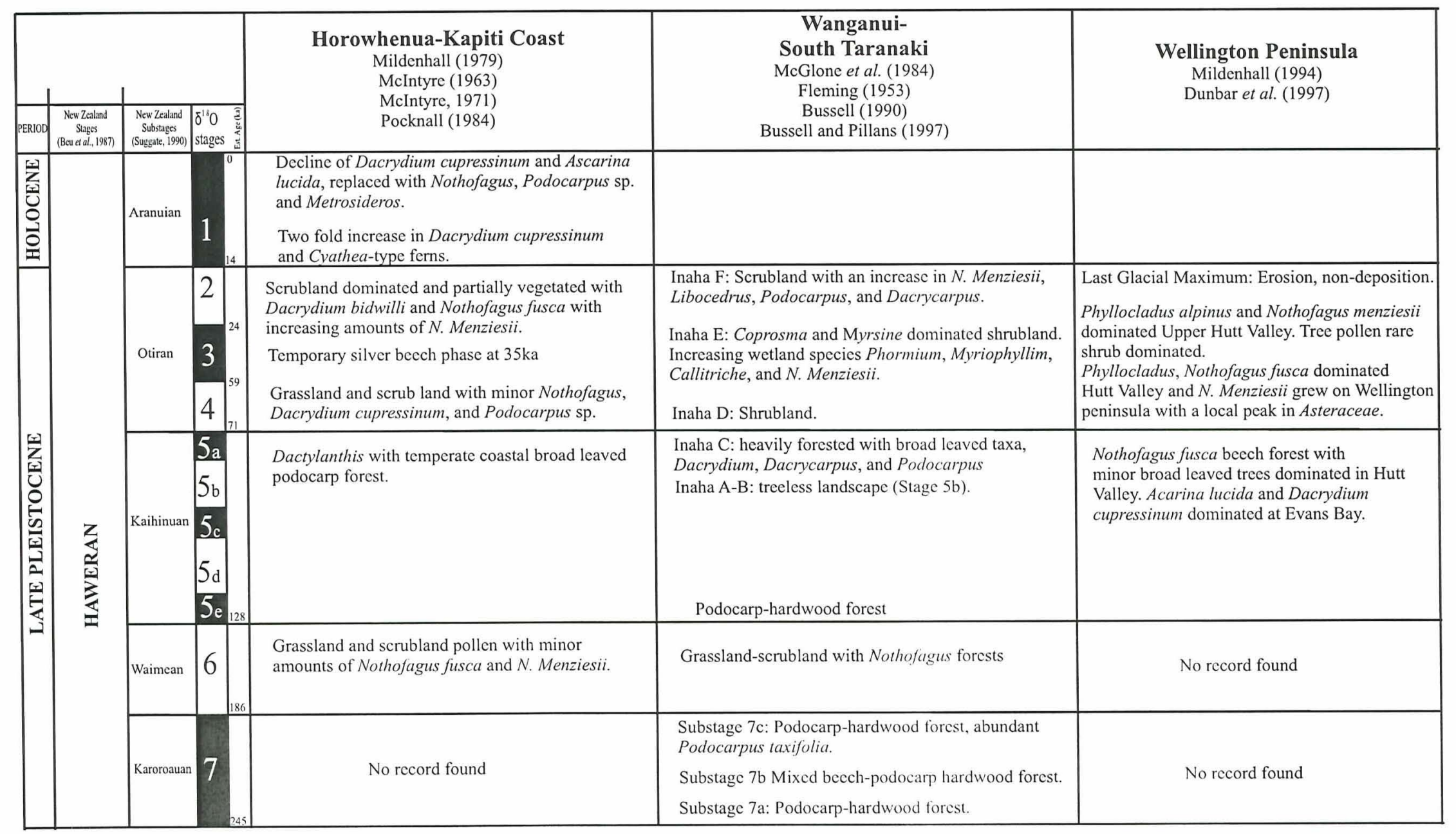




\section{CHAPTER 3}

\section{BOREHOLE STRATIGRAPHY AND FACIES ANALYSIS}

\subsection{INTRODUCTION}

This chapter presents the results of a lithostratigraphic subdivision of the Levin borehole sequence and facies analysis. In the first section, the sequence is subdivided into informal lithostratigraphic units, and the lithological characteristics of each are described. Next the lithostratigraphic units are subdivided into lithofacies, from which generalisations about paleo-depositional environments are made.

\section{LITHOSTRATIGRAPHY}

\subsection{DESCRIPTION OF BOREHOLE SEQUENCE}

The strata within the borehole have been described from a detailed visual inspection of the borehole cuttings. Cuttings were composed of either consolidated chips up to $20 \mathrm{~cm}$ diameter (common in samples rich in silt and clay), or homogenised unconsolidated masses (common in sandy or gravelly samples). Based on changes in lithology, the sequence has been subdivided into 36 lithological units (litho-units) (Fig. 3.1). The lower $110 \mathrm{~m}$ of the borehole (277-170m depth) consists of alternating mud, silt, and sand units each between 5 and $30 \mathrm{~m}$ thick. Between 170-120m depth the borehole is composed of silty sand and sand units and thick gravel units. The top $120 \mathrm{~m}$ of the borehole is dominated by thick gravel units that are separated by thin silt and sand units. A description of the units is summarised below (Table 3.1) and in a detailed graphic log (App. A). 


\begin{tabular}{|c|}
\hline LITHOFACIES CODES \\
\hline Facies-M: Blue-grey mud \\
\hline Facies-FZS: Fossiliferous silty sand \\
\hline Facies-FS: Fossiliferous fine sand \\
\hline Facies-SL: Bioclastic sandy carbonate \\
\hline Facies-SB: Sandy shelly gravel \\
\hline $\begin{array}{l}\text { Facies-S: Barren fine sand } \\
\text { (inc. Sub-facies Sd, Sb) }\end{array}$ \\
\hline Facies-IGM: Interbedded gravel and mud \\
\hline Facies-Z: Brown silt \\
\hline Facies-G: Brown coarse-grained gravel \\
\hline
\end{tabular}

\begin{tabular}{|c|c|c|}
\hline \multicolumn{2}{|c|}{ Lithology } & Fossil and sedimentology \\
\hline $\begin{array}{l}==-7 \\
==-7 \\
=-=-7\end{array}$ & Mud & 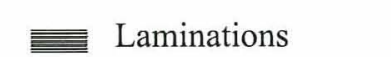 \\
\hline$=\div .7$ & Silt & Spherical clasts \\
\hline 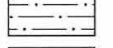 & & (-) Bivalve shells \\
\hline & Sand & 夏 Gastropod shells \\
\hline$\ldots$ & & 3) Shell fragments \\
\hline 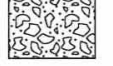 & Gravel & Worm tubes \\
\hline m & Shell hash & 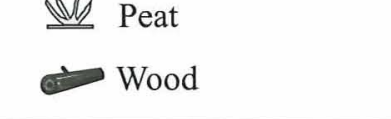 \\
\hline
\end{tabular}

Key for Figure 3.1 


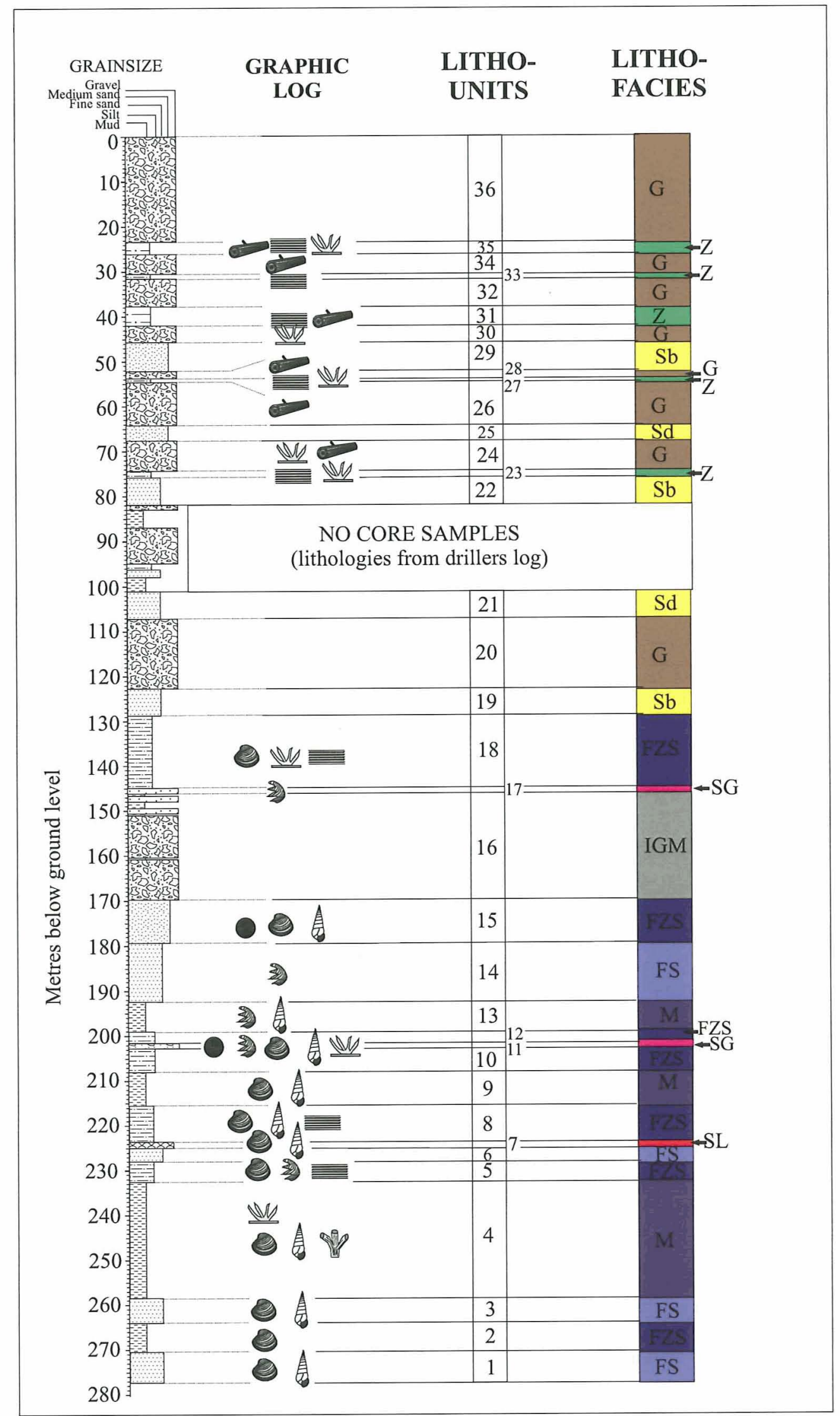

Figure 3.1: Summary log recovered from Levin borehole showing locations of litho-units and lithofacies. 
Table 3.1: Results of a Lithostratigraphic subdivision of the Levin Borehole sequence.

\begin{tabular}{|c|c|c|}
\hline $\begin{array}{l}\text { Litho- } \\
\text { unit }\end{array}$ & $\begin{array}{l}\text { Location } \\
\text { Depth below } \\
\text { ground surface } \\
\text { and thickness } \\
(\mathrm{m}) \\
\end{array}$ & $\begin{array}{l}\text { Description } \\
\text { (Refer to App. B for a full list of macrofossils, and App. A for a graphic borelog) }\end{array}$ \\
\hline 1 & $\begin{array}{l}277.3-270.4 \\
(6.9)\end{array}$ & $\begin{array}{l}\text { Sand. Grey, medium to fine sized, well sorted, fossiliferous, and micaceous. } \\
\text { Contains detrital fragments of the bivalve Austrovenus stutchburyi and whole } \\
\text { specimens of Stiracolpus sp. }\end{array}$ \\
\hline 2 & $\begin{array}{l}270.4-264.5 \\
(5.9)\end{array}$ & $\begin{array}{l}\text { Gravelly silty clay. Greyish green, poorly sorted, consolidated, massive, and } \\
\text { fossiliferous. Clasts consist of sub-rounded greywacke pebbles up to } 1-2 \mathrm{~cm} \text { in } \\
\text { diameter. Large detrital pieces of A. stutchburyi were found between } 263.5-264 \mathrm{~m} \\
\text { depth. }\end{array}$ \\
\hline 3 & $\begin{array}{l}264.5-258.5 \\
(6)\end{array}$ & $\begin{array}{l}\text { Sand. Grey, fine to medium sized, well sorted, micaceous, and fossiliferous. Unit } \\
\text { is composed of 1-2mm thick laminations of blue mud and mica-rich silt. Large } \\
\text { detrital fragments of A. stutchburyi and whole specimens of Amalda depressa } \\
\text { were found between } 261.5-262.5 \mathrm{~m} \text { depth. Sand contains significant amounts of } \\
\text { colourless volcanic glass shard fragments. }\end{array}$ \\
\hline 4 & $\begin{array}{l}258.5-232.8 \\
(25.7)\end{array}$ & $\begin{array}{l}\text { Mud. Blue-grey, very fine grained, well sorted, consolidated, and fossiliferous. } \\
\text { Mud is thinly ( } 2 \mathrm{~cm} \text { thick) bedded and extremely bioturbated between } 258-245 \mathrm{~m} \\
\text { depth and contains Polychaete worm tubes and in situ whole valves of bivalve } \\
\text { Chlamys gemmulata (Reeve), which are byssally attached to the worm tubes. } \\
\text { Between } 245-232 \mathrm{~m} \text { depths the mud is crudely bedded and contains in situ tests of } \\
\text { C. gemmulata and detrital fragments of molluscs A. stutchburyi, Nucula } \\
\text { hartvigiana, Amalda depressa, Stiracolpus symmetricus, Zethalia zelandica, } \\
\text { Stiracolpus sp., and Tiostrea chilensis lutaria. }\end{array}$ \\
\hline 5 & $\begin{array}{l}232.8-228.0 \\
(4.8)\end{array}$ & $\begin{array}{l}\text { Silty sand. Dark grey to blue, fine to very fine grained, moderately well sorted, } \\
\text { and fossiliferous. The unit is composed of } 1-2 \mathrm{~mm} \text { thick planar laminations of } \\
\text { light grey silt and mica-rich sand. Also contains large fragments of A. stutchburyi } \\
\text { and other unidentifiable shell fragments. Unit is rich in volcanic glass fragments. }\end{array}$ \\
\hline 6 & $\begin{array}{l}228.0-225.0 \\
(3.0)\end{array}$ & $\begin{array}{l}\text { Sand. Dark grey to blue, fine to very fine grained, well sorted, and fossiliferous. } \\
\text { Unit is rich in unidentifiable shell fragments. The sand is composed of } \\
\text { approximately } 70 \% \text { quartz, } 10 \% \text { feldspar, } 10 \% \text { muscovite, and } 10 \% \text { biotite, with } \\
\text { minor hypersthene, hornblende, and colourless glass shards. }\end{array}$ \\
\hline 7 & $\begin{array}{l}225.0-223.4 \\
(4.6)\end{array}$ & $\begin{array}{l}\text { Sandy shell hash. Grey to yellow loosely compacted shell hash with grey, fine } \\
\text { grained, well sorted sandy matrix and traces of gravel. Contains both whole and } \\
\text { broken fossil molluscs of: Divaricella huttoniana; Tawera spissa; Myadora } \\
\text { striata; Pleuromeris finlayi; A. stutchburyi; C. gemmulata; N. hartvigiana; } \\
\text { Zenatia acinaces; Barytellina crassidens; Cellana sp.; S. symmetricus; } \\
\text { Zeacumantus lutulentus; A. depressa; Xymene pleibeius; Z. zelandica; }\end{array}$ \\
\hline
\end{tabular}




\begin{tabular}{|c|c|c|}
\hline & & $\begin{array}{l}\text { Stiracolpus sp.; Aeneator sp.; Micrelenchus dilatatus; Cominella nassoides; and, } \\
\text { Buccinulum sp. The composition of the sand is similar to unit } 6 \text {. }\end{array}$ \\
\hline 8 & $\begin{array}{l}223.4-215.3 \\
(8.1)\end{array}$ & $\begin{array}{l}\text { Silty sand. Dark grey to blue, fine grained, well sorted, loosely consolidated, } \\
\text { fossiliferous, and micaceous. Contains Paphies australis, Paphies sp., Z. } \\
\text { acinaces, and Stiracolpus sp. P. australis and Z. acinaces are in situ. The sand } \\
\text { fraction is composed of approximately } 75 \% \text { quartz, 10\% feldspar, and } 15 \% \\
\text { muscovite with traces of colourless glass shards. }\end{array}$ \\
\hline 9 & $\begin{array}{l}215.3-208.0 \\
(7.3)\end{array}$ & $\begin{array}{l}\text { Mud. Grey to dark brown, poorly sorted, fine grained, massive, slightly } \\
\text { consolidated, and fossiliferous clayey silt. Contains whole specimens of } \\
\text { Stiracolpus sp., S. symmetricus, and Tanea zelandica and other unidentifiable } \\
\text { shell fragments. }\end{array}$ \\
\hline 10 & $\begin{array}{l}208.0-202.2 \\
(5.8)\end{array}$ & $\begin{array}{l}\text { Sandy mud. Dark grey to brown, very poorly sorted, slightly cohesive, } \\
\text { fossiliferous, and slightly organic. Contains detrital fragments of A. stutchburvi; } \\
\text { T. chilensis lutaria; Paphies sp.; Z. acinaces; and, Stiracolpus sp. }\end{array}$ \\
\hline 11 & $\begin{array}{l}201.5-202.2 \\
(0.7)\end{array}$ & $\begin{array}{l}\text { Fossiliferous gravel. Blue rounded fresh gravel and shells. Clasts consist of sub- } \\
\text { rounded to well-rounded greywacke pebbles, some of which have been shaped } \\
\text { into disc and sphere shapes. Fossil content is composed of molluscs Z. acinaces } \\
\text { and } P \text {. finlayi and other unidentifiable shell fragments. }\end{array}$ \\
\hline 12 & $\begin{array}{l}199.4-201.5 \\
(2.1)\end{array}$ & $\begin{array}{l}\text { Muddy sand. Dark grey to brown, very poorly sorted, slightly cohesive, } \\
\text { fossiliferous, and slightly organic. Contains detrital fragments of molluses A. } \\
\text { stutchburyi; P. finlayi; T. spissa; and, Stiracolpus sp. }\end{array}$ \\
\hline 13 & $\begin{array}{l}199.4-192.2 \\
(7.2)\end{array}$ & $\begin{array}{l}\text { Mud. Dark grey to blue, poorly sorted and very fine grained, and fossiliferous } \\
\text { silty clay. Contains whole specimens of Stiracolpus sp. and bivalve fragments. }\end{array}$ \\
\hline 14 & $\begin{array}{l}192.2-179.5 \\
(12.7)\end{array}$ & $\begin{array}{l}\text { Sand. Dark grey to brown, medium sized, very well sorted, and fossiliferous. } \\
\text { Contains small detrital shell fragments that were unable to be identified. Sand is } \\
\text { composed of approximately } 75 \% \text { quartz, 10\% feldspar, 10\% muscovite, and 5\% } \\
\text { biotite and colourless glass shards. }\end{array}$ \\
\hline 15 & $\begin{array}{l}179.5-169.9 \\
(9.4)\end{array}$ & $\begin{array}{l}\text { Gravelly silty sand. Grey poorly sorted, loosely compacted, and fossiliferous. } \\
\text { Clasts are composed of sub-rounded greywacke and argillite pebbles up to } 4 \mathrm{~cm} \\
\text { in diameter, some of which form distinct rod and sphere shapes. Unit contains } \\
\text { several whole specimens of A. stutchburyi, T. chilensis lutaric, P. finlavi. } \\
\text { Stiracolpus sp., and A. depressa and traces of wood and peat. }\end{array}$ \\
\hline 16 & $\begin{array}{l}169.9-146.0 \\
(23.9)\end{array}$ & $\begin{array}{l}\text { Interbedded blue gravel and grey-green mud. Blue coarse-grained, } \\
\text { moderately well sorted gravel in a quartz-rich silty sand matrix. Clasts consist of } \\
\text { sub-angular to rounded greywacke pebbles and cobbles, up to } 10 \mathrm{~cm} \text { in diameter. } \\
\text { Green mud beds are consolidated, massive, very poorly sorted, and barren. }\end{array}$ \\
\hline 17 & $\begin{array}{l}146.0-144.9 \\
(1.1)\end{array}$ & $\begin{array}{l}\text { Fossiliferous gravel. Gravel is composed of clasts similar to unit } 16 \text {, but also } \\
\text { contains shell fragments including several tests of the bivalve } P \text {. finlayi. }\end{array}$ \\
\hline 18 & $\begin{array}{l}144.9-130.5 \\
(14.4)\end{array}$ & Silty sand. Dark grey, fine grained, poorly sorted, and fossiliferous. Unit is \\
\hline
\end{tabular}




\begin{tabular}{|c|c|c|}
\hline & & $\begin{array}{l}\text { composed of } 1-2 \mathrm{~mm} \text { thick laminations of fine blue silt and } 1 \mathrm{~cm} \text { thick blue mud } \\
\text { loams and large detrital fragments of A. stutchburyi and small fragments of } \\
\text { Paphies sp. }\end{array}$ \\
\hline 19 & $\begin{array}{l}130.5-122.6 \\
(7.9)\end{array}$ & $\begin{array}{l}\text { Sand. Grey, fine to medium sized, well sorted, and barren. The sand is composed } \\
\text { of approximately } 90 \% \text { quartz, } 5 \% \text { feldspar, and } 5 \% \text { muscovite and biotite grains. }\end{array}$ \\
\hline 20 & $\begin{array}{l}122.6-107 \\
(15.6)\end{array}$ & $\begin{array}{l}\text { Gravel. Blue, coarse-grained, poorly sorted gravel with grey coarse sandy } \\
\text { matrix. Clasts consist of angular to sub-rounded greywacke pebbles and cobbles } \\
\text { up to } 10 \mathrm{~cm} \text { in diameter; mostly } 1-4 \mathrm{~cm} \text {. Matrix contains a moderately well sorted } \\
\text { mixture of grey gritty sand. }\end{array}$ \\
\hline 21 & $\begin{array}{l}107-101.1 \\
(5.9)\end{array}$ & $\begin{array}{l}\text { Sand. Grey, fine to very fine sized, very well sorted, and barren. The sand is } \\
\text { composed of approximately } 85 \% \text { quartz, } 10 \% \text { muscovite, and } 5 \% \text { biotite grains. }\end{array}$ \\
\hline $\mathbf{X}$ & $\begin{array}{l}101.1-81.9 \\
(24.3)\end{array}$ & $\begin{array}{l}\text { No core samples and no units defined from this part of core. } \\
\text { Lithologies on Fig. } 3.1 \text { and App. } 1 \text { are from driller's well log. }\end{array}$ \\
\hline 22 & $\begin{array}{l}81.9-75.4 \\
(6.5)\end{array}$ & $\begin{array}{l}\text { Sand. Light brown, medium to fine sized, well sorted, and barren. Mineral } \\
\text { composition is similar to that in Unit } 20 \text {. }\end{array}$ \\
\hline 23 & $\begin{array}{l}75.4-74.1 \\
(1.3\end{array}$ & $\begin{array}{l}\text { Sandy silt. Light brown to dark grey, poorly sorted, and slightly-consolidated. } \\
\text { Contains crude laminations, } 1-2 \mathrm{~mm} \text { thick, and irregular brown staining and dark } \\
\text { mottles of fine-grained organic debris. }\end{array}$ \\
\hline 24 & $\begin{array}{l}74.1-68.8 \\
(5.3)\end{array}$ & $\begin{array}{l}\text { Gravel. Light brown, coarse-grained, and very poorly sorted. Clasts consist of } \\
\text { rounded to sub-rounded greywacke pebbles up to } 5 \mathrm{~cm} \text { in diameter. Some clasts } \\
\text { are fresh but most are extremely weathered to a brown colour and show evidence } \\
\text { of abrasion. The matrix is composed of medium sized, moderately well sorted } \\
\text { sand consisting of quartz, mica and feldspar. This unit also contains traces of peat } \\
\text { and large pieces of wood. }\end{array}$ \\
\hline 25 & $\begin{array}{l}68.8-64.2 \\
(4.6)\end{array}$ & $\begin{array}{l}\text { Silty sand. Light brown, medium to fine sized, well sorted, barren, and loamy. } \\
\text { The sand contains distinct mica, hypersthene, and hornblende grains, and } \\
\text { colourless glass shards. }\end{array}$ \\
\hline 26 & $\begin{array}{l}64.2-54.2 \\
(10)\end{array}$ & $\begin{array}{l}\text { Gravel. Blue gravel with a loose brown sandy matrix. Approximately 50:50 } \\
\text { mixture of gravel and sand that increases to } 60 \% \text { gravel at } 55 \mathrm{~m} \text { and } 80 \% \text { gravel } \\
\text { at } 58 \mathrm{~m} \text {. Some wood chips were present in this unit. }\end{array}$ \\
\hline 27 & $\begin{array}{l}54.2-53.6 \\
(0.6)\end{array}$ & $\begin{array}{l}\text { Silt. Dark grey to brown, very fined grained, moderately cohesive, and } \\
\text { carbonaceous. Unit contains crude laminations, } 1-2 \mathrm{~mm} \text { thick, and rare rounded } \\
\text { greywacke pebbles up to } 2 \mathrm{~cm} \text { in diameter. Some organic material is also present. }\end{array}$ \\
\hline 28 & $\begin{array}{l}53.6-42.0 \\
(11.6)\end{array}$ & $\begin{array}{l}\text { Gravely sand. Dark brown, very poorly sorted, and quartz-rich. Clasts consist of } \\
\text { sub-angular greywacke up to } 5 \mathrm{~cm} \text { in diameter. Contains small pieces of wood. }\end{array}$ \\
\hline 29 & $\begin{array}{l}42.0-37.8 \\
(4.2)\end{array}$ & $\begin{array}{l}\text { Sand. Grey to brown, medium sized, very well sorted, and barren. The sand is } \\
\text { composed of approximately } 70 \% \text { quartz, } 15 \% \text { feldspar, } 10 \% \text { mica, and } 5 \% \\
\text { hypersthene and colourless glass shards. }\end{array}$ \\
\hline 30 & $\begin{array}{l}37.8-37.4 \\
(0.4)\end{array}$ & Gravel. Brown, poorly sorted gravel with a brown sandy matrix. Clasts are \\
\hline
\end{tabular}




\begin{tabular}{|c|c|c|}
\hline & & $\begin{array}{l}\text { composed of sub-angular to sub-rounded greywacke pebbles up to } 5 \mathrm{~cm} \text { in } \\
\text { diameter. Matrix consist of coarse to medium sized sand grains. Fibrous organic } \\
\text { material was found between } 37.4-39 \mathrm{~m} \text { depth. }\end{array}$ \\
\hline 31 & $\begin{array}{l}37.4-36.3 \\
(1.1)\end{array}$ & $\begin{array}{l}\text { Silt. Light grey, fine grained, poorly sorted, and carbonaceous. Contains small, 1- } \\
2 \mathrm{~mm} \text { thick, laminations, which show colour change from light brown to pale } \\
\text { grey. Also contains wood and charcoal pieces up to } 3 \mathrm{~cm} \text { long and } 1 \mathrm{~cm} \text { wide, and } \\
\text { rare rounded greywacke granules up to } 1 \mathrm{~cm} \text { diameter. }\end{array}$ \\
\hline 32 & $\begin{array}{l}36.3-31.7 \\
(4.6\end{array}$ & $\begin{array}{l}\text { Gravel. Brown, poorly sorted gravel with a brown silty sand matrix. Clasts } \\
\text { consist of angular greywacke pebbles } 1-3 \mathrm{~cm} \text { in diameter, which are mixed with a } \\
\text { brown poorly sorted coarse to medium sized sand matrix. Contains no fossil } \\
\text { material. }\end{array}$ \\
\hline 33 & $\begin{array}{l}31.7-30.5 \\
(1.2)\end{array}$ & $\begin{array}{l}\text { Silty clay. Light grey to light brown, very fine grained, consolidated, and } \\
\text { carbonaceous. Contains thin laminations, } 1-2 \mathrm{~mm} \text { thick, of alternating pale } \\
\text { whitish grey to light brown layers. Some laminations are wavy and form small } \\
\text { asymmetrical ripples. Contains no fossil material. }\end{array}$ \\
\hline 34 & $\begin{array}{l}30.5-26.0 \\
(4.5)\end{array}$ & $\begin{array}{l}\text { Gravel. Brown to blue moderately well sorted gravel with a brown silty sand } \\
\text { matrix. Clasts are composed of sub-angular to rounded greywacke and quartz } \\
\text { pebbles up to } 2 \mathrm{~cm} \text { in diameter which increases to } 5-8 \mathrm{~cm} \text { in diameter at } 30 \mathrm{~m} \\
\text { depth. The matrix is a poorly sorted, medium to coarse sized, quartz-rich silty } \\
\text { sand. Contains wood chips up to } 2 \mathrm{~cm} \text { long. }\end{array}$ \\
\hline 35 & $\begin{array}{l}26.0-23.3 \\
(2.7)\end{array}$ & $\begin{array}{l}\text { Sandy mud. Dark grey, very fine grained, poorly sorted, and carbonaceous. } \\
\text { Contains thin laminations, } 1-2 \mathrm{~mm} \text { thick, of alternating dark brown clay and light } \\
\text { grey silt, and small rounded greywacke stones. Unit has high organic content } \\
\text { comprising charcoal and fragments of stems, roots, and twigs. }\end{array}$ \\
\hline 36 & $\begin{array}{l}23.3-0.0 \\
(23.3)\end{array}$ & $\begin{array}{l}\text { Gravel. Brown, poorly sorted, coarse-grained gravel with a greyish brown silty } \\
\text { sand matrix. Clasts consist of sub-rounded to angular greywacke, argillite and } \\
\text { quartz pebbles and cobbles which range from } 2 \mathrm{~cm} \text { to } 20 \mathrm{~cm} \text { in diameter but are } \\
\text { mainly } 5-10 \mathrm{~cm} \text { in diameter. Clasts are weathered to a rusty brown colour in } \\
\text { places and show evidence of abrasion. Matrix is composed of poorly sorted, } \\
\text { quartz-rich silty sand. Unit contains no fossil material. }\end{array}$ \\
\hline
\end{tabular}




\section{FACIES ANALYSIS}

\subsection{INTRODUCTION TO FACIES ANALYSIS}

Nine recurrent lithofacies have been recognised from the borehole sequence: blue-grey mud facies (M); fossiliferous silty sand facies (FZS); fossiliferous fine well sorted sand facies (FS); bioclastic sandy carbonate (SL) facies; Dark grey to brown shelly gravel (SG); fine, well sorted, barren sand facies (S); interbedded gravel and mud facies (IGM); brown silt facies ( $\mathbb{Z}$ ); and a, brown coarse-grained gravel facies (G) (Fig. 3.1; Table 3.2). Facies $\mathbf{S}$ also contains two sub-facies that were found after further sedimentological analysis provided more details of sediment characteristics.

The depositional environments interpreted for each of the lithofacies have been determined primarily from sediment texture and macro-fauna found in the samples. Sedimentary structures have also been used where possible; however, due to the nature of the drilling method they were only obtained from samples comprised of consolidated chips.

\subsection{DESCRIPTION AND INTERPRETATION OF LITHOFACIES}

\subsubsection{Facies $M$ - Blue-grey fossiliferous mud}

Facies $\mathbf{M}$ is composed of a blue to grey, consolidated, slightly calcareous fossiliferous mud (Fig. 3.2). The mud is poorly sorted and is composed of approximately $48-52 \%$ silt, $41-47 \%$ clay, and $4-5 \%$ sand. The majority of strata in the facies is crudely bedded and contains in situ molluscs of $C$. gemmulata and detrital fragments A. stutchburyi, $N$. hartvigiana, A. depressa, S. symmetricus, Z. zelandica, Stiracolpus sp., and T. chilensis lutaria. However, some of the strata assigned to this facies (i.e. between 260-245m depth) is extremely bioturbated and contains in situ Polychaete worm tubes and the marine bivalve $C$. gemmulata that are byssally attached to the worm tubes. 
Table 3.2: Summary of Lithofacies and Lithofacies interpretations described in Levin borehole

\begin{tabular}{|c|c|c|c|c|}
\hline Facies code & Lithology & Fossil Content & Environment & $\begin{array}{l}\text { Typical Grainsize } \\
\text { Frequency Histogram }\end{array}$ \\
\hline M & $\begin{array}{l}\text { BLUE-GREY MUD } \\
\text { Finc-grained, poorly sorted, consolidated, fossiliferous mud. Some } \\
\text { scdiment assinged to the cacics is highly bioturbated, but most are } \\
\text { crudely bedded to massive. }\end{array}$ & 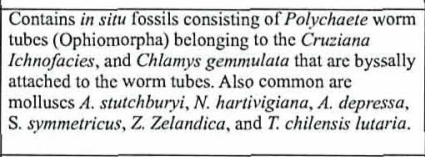 & $\begin{array}{l}\text { Middle- to inner-shelf, or deep marine } \\
\text { embayment. }\end{array}$ & 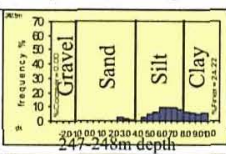 \\
\hline irs: & 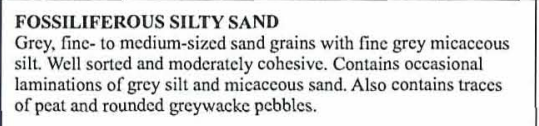 & 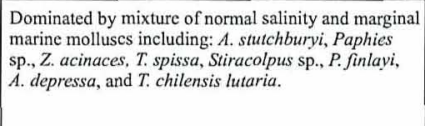 & $\begin{array}{l}\text { Middle- to outer-shoreface near offshore } \\
\text { sand-mud transition zone or marginal marine } \\
\text { (estuarine) embayment. }\end{array}$ & \\
\hline FS & 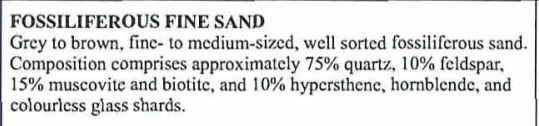 & $\begin{array}{l}\text { Detrital fragments of marine molluscs and whole tests } \\
\text { of } A \text {. Stutchburyi and } A \text {. depressa. }\end{array}$ & $\begin{array}{l}\text { Middle- to inner-shoreface. Offshore from a } \\
\text { wave-dominated with nearby cstuarinc environment, } \\
\text { or partially protected beach. }\end{array}$ & \\
\hline SL & $\begin{array}{l}\text { BIOCLASTIC SANDY CARBONATE } \\
\text { grey, loosely compacted pcbbly sandy un-cemented shell hash. } \\
\text { Siliciclastic sediment tomprprises grey well sorted, medium-sized } \\
\text { sand. Clasts consist of rounded, spherical greywacke fragments. }\end{array}$ & 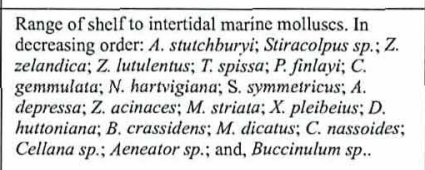 & $\begin{array}{l}\text { Shoreface. Most likely terrigenous starved } \\
\text { shorefacc-shelf environment. }\end{array}$ & \\
\hline SG & $\begin{array}{l}\text { SANDY SHELLY GRAVEL } \\
\text { Dark grey to brown loosely compacted poorly sorted shelly gravel. } \\
\text { Clasts are rounded to very well rounded spherical greywacke } \\
\text { pebbles. }\end{array}$ & Shcll fragments and $P$. finlayi and $Z$. Acinaces & $\begin{array}{l}\text { Inner-shorefiace. High energy, wave- } \\
\text { dominated coastlinc. }\end{array}$ & \\
\hline$\underset{(S d, S b)}{S}$ & 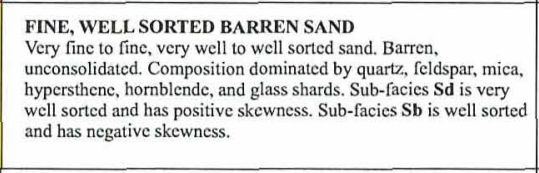 & Barren & $\begin{array}{l}\text { Littoral coastal sand deposits, } \\
\text { Sub-facies Sd reprecents acolian dunc sand deposits. } \\
\text { Sub-facies Sb represents becach f(foreshore or } \\
\text { backshore) bcach sand deposits. }\end{array}$ & $64.2-65.3 \mathrm{~m}$ depth \\
\hline IGM & $\begin{array}{l}\text { INTERBEDDED GRAVELAND MUD } \\
\text { Bluc coarse-grained gravel interbedded with green mud. Gravel is } \\
\text { weakly cemented, barren, and moderately well sorted, Clasts } \\
\text { comprise sub-angular to rounded greywacke and argillite. }\end{array}$ & Barren & Fresh water fluvial-deltaic deposit. & \\
\hline & $\begin{array}{l}\text { Green mud is consolidated, barren, and massive. Also contains small } \\
\text { rounded greywacke pebbles. }\end{array}$ & & & d from 161.4.161.6m depph \\
\hline $\mathrm{z}$ & $\begin{array}{l}\text { BROWN SILT } \\
\text { Brownish grey finc-grained, organic, consolidated sandy silt or } \\
\text { clayecy silt. Contains thin dark brown to light grey parallele and } \\
\text { ripple-laminations. Also contains rare rounded greywacke pebbles. }\end{array}$ & $\begin{array}{l}\text { High organic content consisting of pcat, wood chips, } \\
\text { roots, nodules, stems, and charcoal. }\end{array}$ & $\begin{array}{l}\text { Fluvial over bank, noodplain deposists. } \\
\text { Finc-grained particles deposited in sub-aqeuous } \\
\text { cnvironment in partially vegetated oxbows, } \\
\text { abandoned channcls, or terrace tops. }\end{array}$ & \\
\hline G & 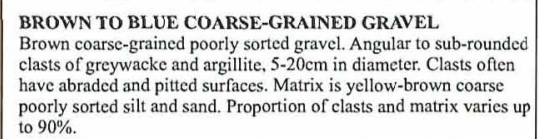 & $\begin{array}{l}\text { Predominately organic consisting of peat and } \\
\text { pieces of wood up to } 20 \mathrm{~cm} \text { long. }\end{array}$ & $\begin{array}{l}\text { Fluvial gravel braided river channel, alluvial plain } \\
\text { or terrace deposits. }\end{array}$ & \\
\hline
\end{tabular}



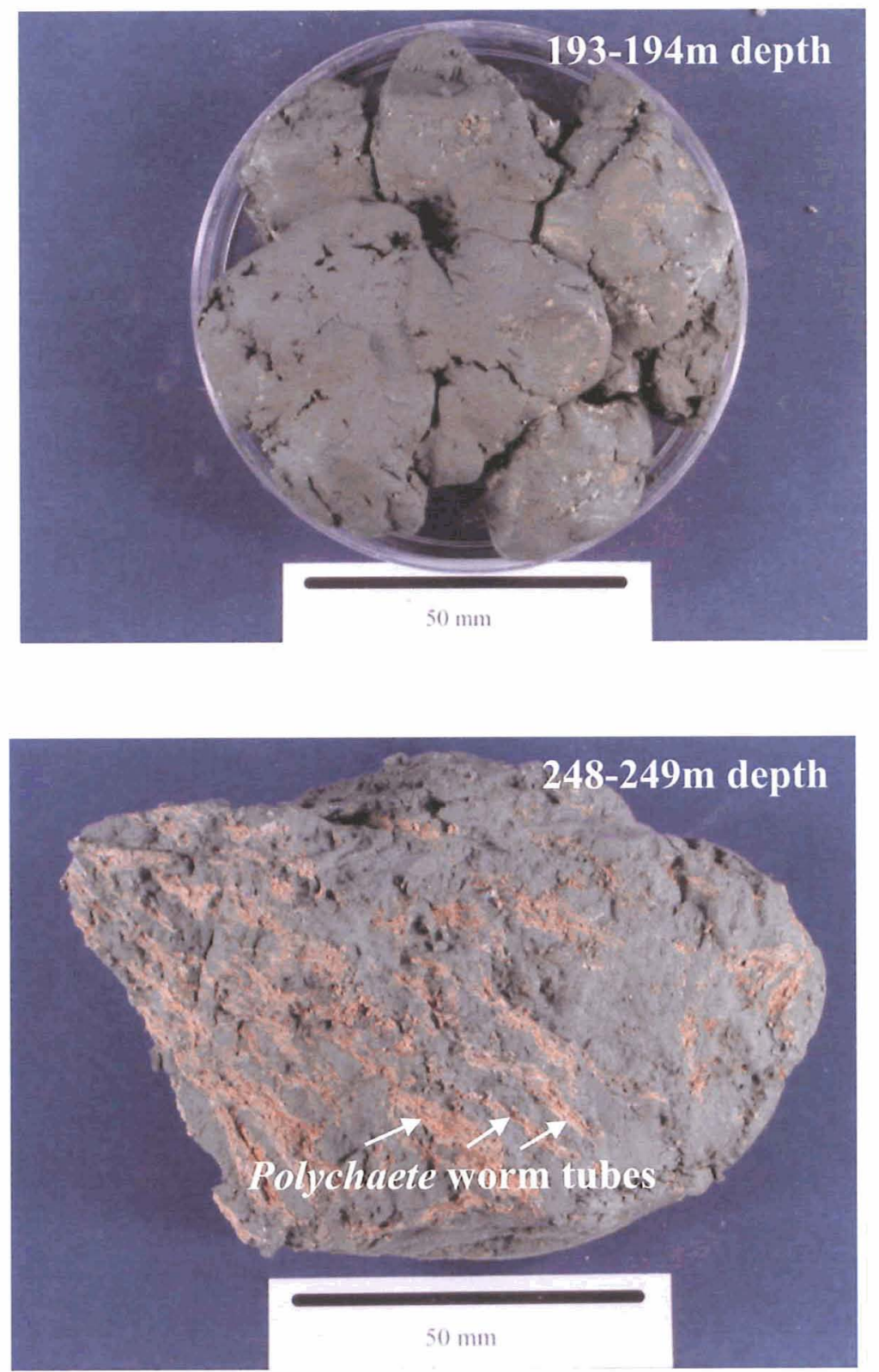

Figure 3.2: Photographs of two different units assigned to Facies M -

Blue-grey fossiliferous mud. Bottom is bioturbated blue-grey fossiliferous mud that is protruded by siliceous worm tubes (Polychaete) belonging to the Cruziana Ichnofacies (sample from 248-249m depth). Top is non-bioturbated blue grey fossiliferous mud (sample from 193-194m depth). 
Worm tubes consist of silica-lined branched burrows or dwelling structures (Domichnia) that belong to Cruziana ichnofacies (Pemberton et al., 1992). Bioturbation results in a mottled texture consisting of siliciclastic debris and shell fragments.

Litho-units 4, 9, and 13 assigned to Facies $\mathbf{M}$ are variable in thickness (between $25-7 \mathrm{~m}$ thick), and are on average $12 \mathrm{~m}$ thick (Fig. 3.1). These mud deposits are interpreted to represent the deepest marine environment recorded in the borehole. High bioturbation rates, faunal composition, and fine mean grainsize suggest deposition within a quiet, muddy bottomed inner shelf or within a large protected embayment ( $c f$. Facies M Mitchell, 2001). This interpretation assumes a wave-graded shelf-shoreface environment, where mud is the most common sediment type that accumulates below fair weather wave base on the inner shelf (Fig. 3.3) (Perrett, 1990; Dunbar and Barrett, 2005). Similarly, Cruziana ichnofacies, which is found in litho-unit 4, are found below fair weather wave base in offshore muddy, low energy environments (Fig. 3.3) (Pemberton et al., 1992). Detrital estuarine-dwelling molluscs that are common in units assigned to this facies were probably washed in from the intertidal zone and are not accurate indicators of past environmental conditions. However, the presence of an estuarine fauna may indicate expansive estuaries and tidal flats existed in adjacent environments during deposition of these units. Since estuaries commonly form from coastal submergence, Facies M maybe associated with a relative sea level highstand (e.g. Curray, 1964; Boyd et al., 1992; Dalrymple et al., 1992).

\subsubsection{Facies FZS - Fossiliferous silty sand}

Facies FZS refers to litho-units consisting of grey, fossiliferous, moderately well sorted silty sand (Fig. 3.1). Lithologies range from unconsolidated silty sand to slightly consolidated sandy silt, which often contains thin ( $1 \mathrm{~cm}$ thick) planar-laminations of blue mud and grey micaceous sand (Fig. 3.4). Grainsize frequency histograms contain a bimodal distribution consisting of sand and silt illustrating this (Table 3.2). 


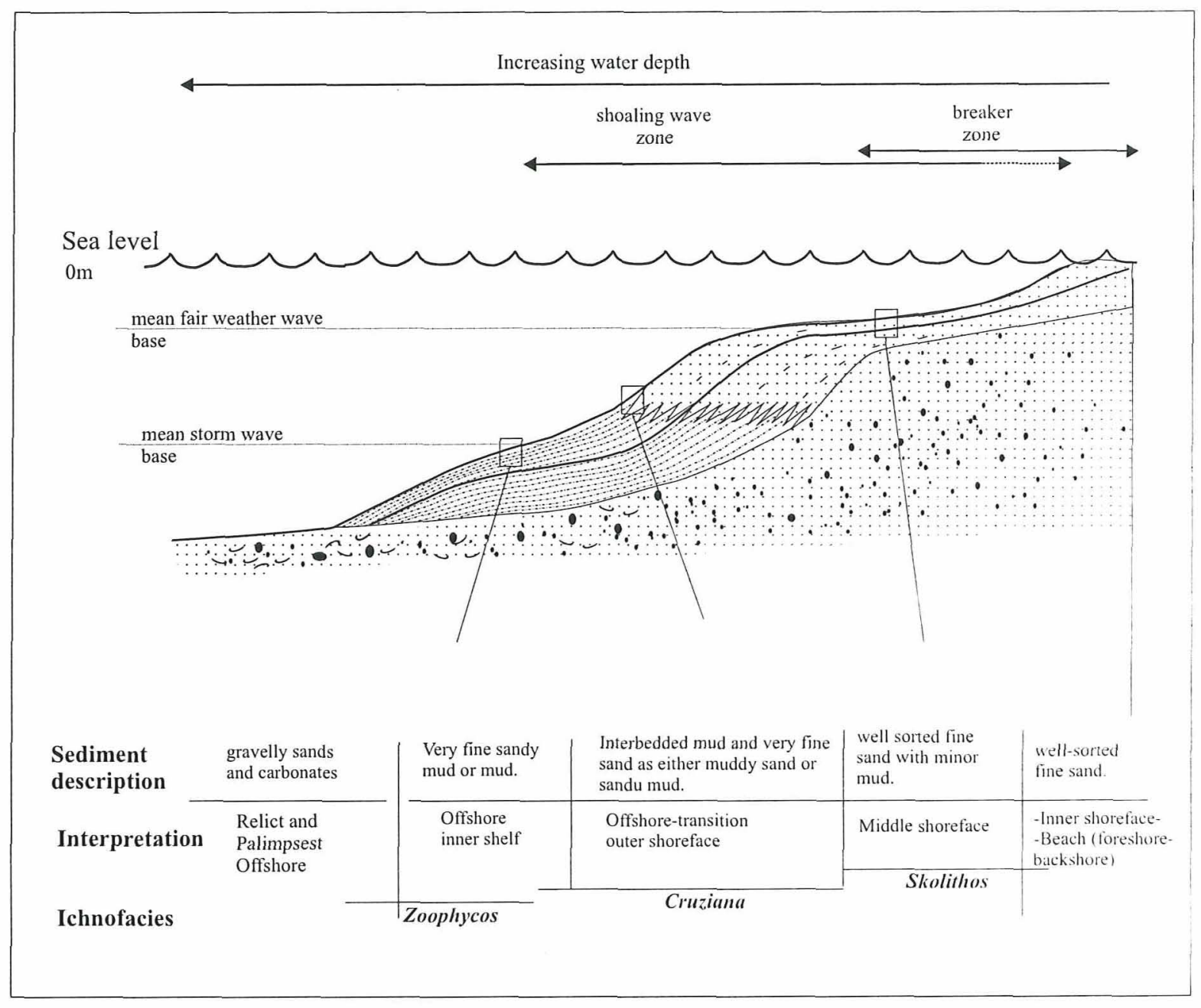

Figure 3.3: Shelf-shoreface sedimentation and ichnofacies profile labelled with marine environments mentioned in this study as they relate to wave base.

(Model modified from Walker and James, 1992; Ichnofacies zones from

Pemberton et al., 1992) 

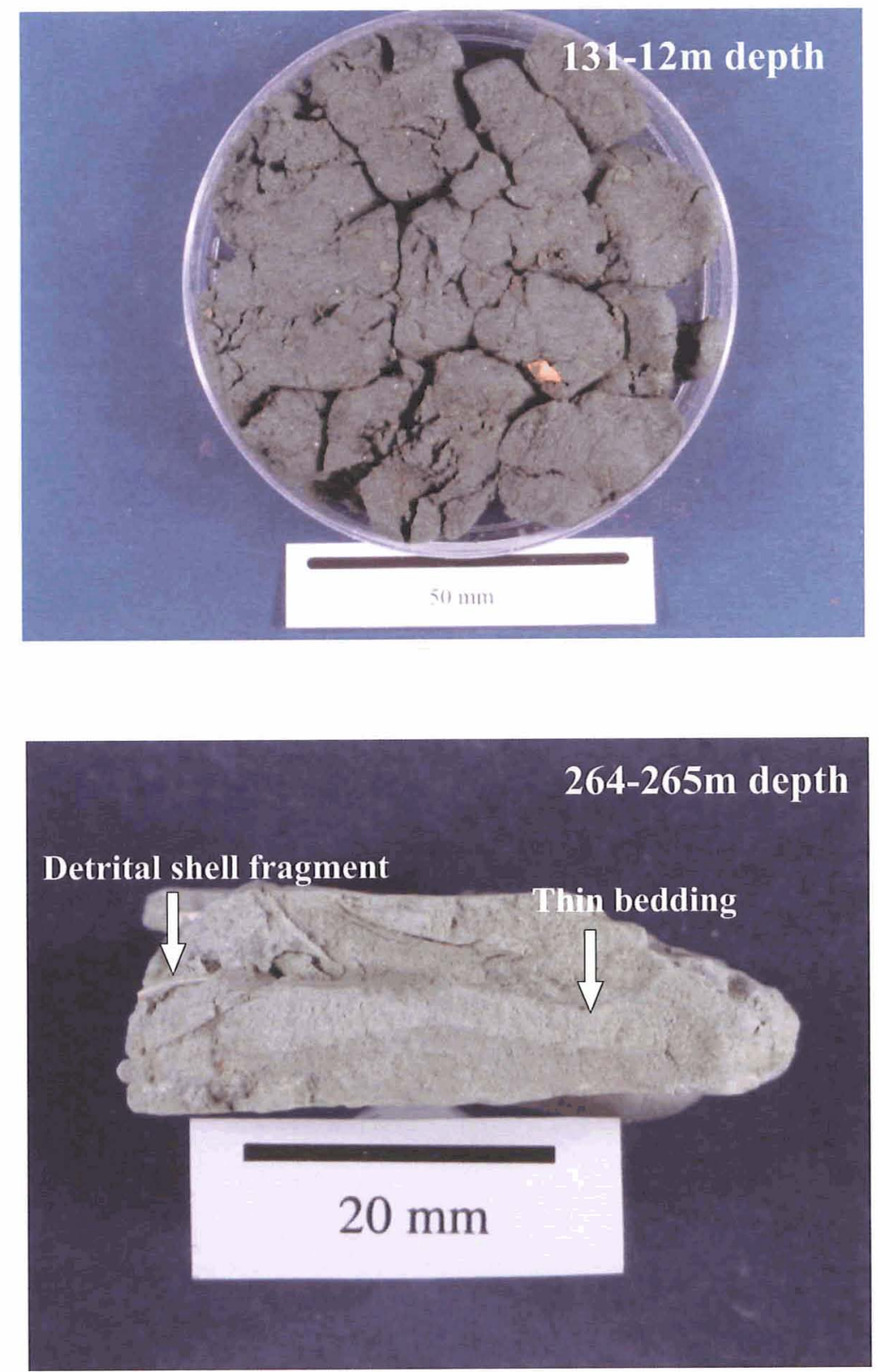

Figure 3.4: Photographs of some units composed of Facies FZS - Grey fossiliferous silty sand. Top is unconsolidated silty sand that is mica rich (Sample from 131-132m depth). Bottom is thinly bedded cohesive silty sand that contains detrital estuarine shell fragments and thin beds of green-grey silt and grey-brown sand (sample from 264-265m depth). 
Fossil fauna present in units assigned to facies FZS contain a mixture of estuarine dwelling and normal salinity molluscs such as A. stutchburyi, Paphies sp., Z. acinaces, T. spissa, Stiracolpus sp., P. finlayi, A. depressa, and T. chilensis lutaria. In some cases, the units also contain traces of peat and wood and occasional rounded greywacke pebbles.

Litho-units 2, 5, 8, 10, 12, 15 and 18 attributed to Facies FZS range from $3 \mathrm{~m}$ to $9 \mathrm{~m}$ thick. They are interpreted to represent either a tidally influenced estuarine environment or middle- to outer-shoreface environment based on the bimodal distribution of sand and silt grains present. Two interpretations are suggested because mixtures of sand and silt can be representative of the sand-mud transition zone, which occurs offshore from wave graded coastlines on the middle- to outer-shoreface (Perrett, 1990; Dunbar and Barrett, 2005) (Fig. 3.3). Alternatively, silty sand facies can form within tidal estuaries, where the presence of thin laminations is usually a good indicator of such conditions (Reinson, 1992). The environmental interpretation can be further refined for litho-units containing low diversity intertidal and sub-tidal faunal assemblages (e.g. units 2, 10, 12 , 15, and 18), which are almost certainly in situ and indicate an estuarine environment (cf. Reinson, 1992). Similarly, units that contain traces of peat and gravel (e.g. units 15 and 18) may reflect an influence of the fluvial realm indicating an inner-estuarine environment (e.g. Dalrymple et al., 1992). However, the exact origin of litho-units containing Facies FZS can be resolved using microfossils (see Chapter 4).

\subsubsection{Facies FS - Grey to brown fossiliferous fine well sorted sand}

Litho-units consisting of grey to brown, fossiliferous, well sorted, fine, micaceous sands (Fig. 3.5) are assigned to Facies FS (Fig. 3.1). These sands contain between 88-90\% sand-sized grains that have a standard deviation of between $0.8-1.0$ phi and mean grain size of around 3.0 phi units (App. C). Faunal composition generally consists of detrital fragments of mollusc's A. stutchburyi and A. depressa. 


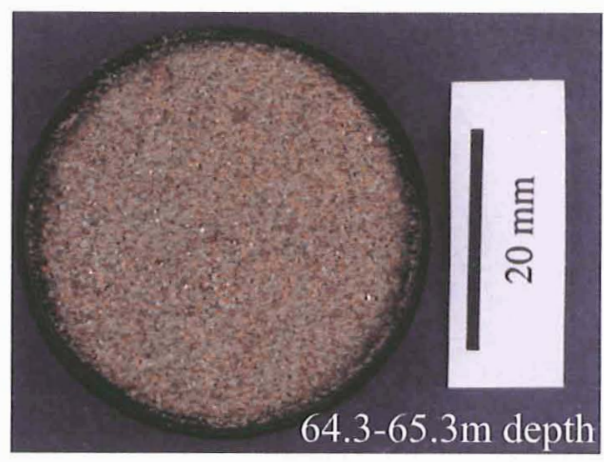

Sub-facies Sd: very well sorted fine to very fine micaceous sand.

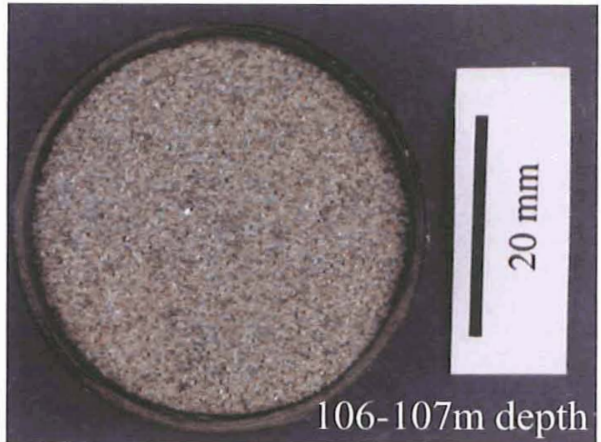

Sub-facies Sd: very well sorted fine to very fine micaceous sand.

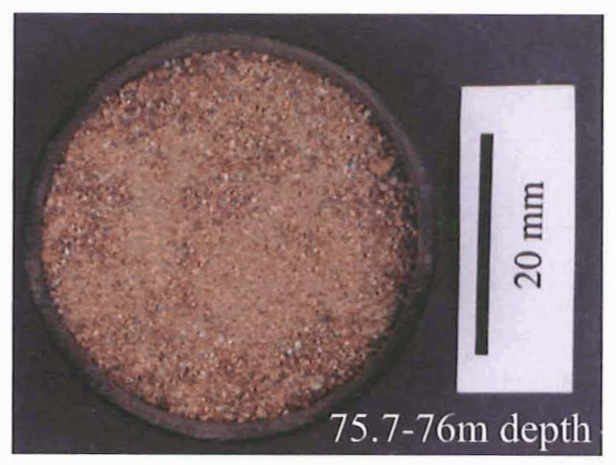

Sub-facies Sb: well sorted fine to medium micaceous sand.

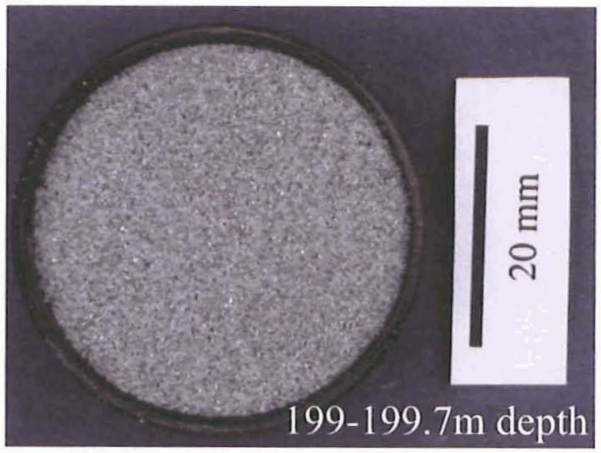

Facies FS: well sorted, fine to medium fossiliferous sand.

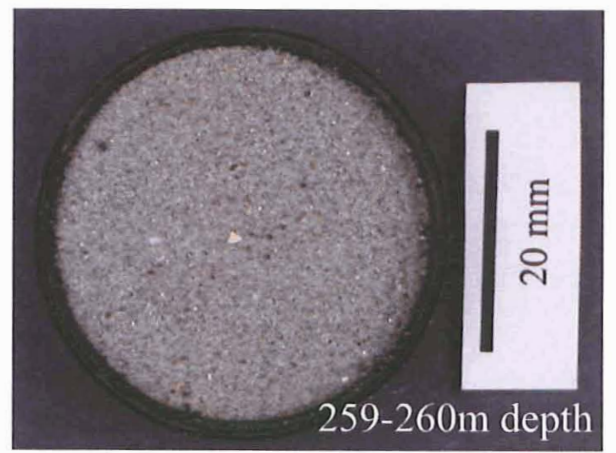

Facies FS: well sorted, fine to medium fossiliferous sand.

Figure 3.5: Photographs showing the contrast between units composed of fine well sorted sand facies (Sd, SB, and FS). Note Sb (beach sand) is slightly coarser and less well sorted than Sd (dune sand). In contrast, Facies FS contains moderately-sized well sorted sand with shell fragments. 
Units 1, 3, 6, and 14 that contain Facies FS are generally between 5-10m thick. These units are interpreted as representing tidal inner-shoreface deposits based on faunal composition and the well sorted nature of the sand grains (Table 3.2). For example, the low mud content exhibited in the sands is characteristic of a wave dominated environment where fine grained material is either in suspension or has been winnowed out to sea (Perrett, 1990; Swift and Thorne, 1991) (Fig. 3.3).

\subsubsection{Facies SL - Grey bioclastic sandy carbonate}

Facies SL encompasses litho-unit 7 located between 223-224m depth (Fig. 3.1), which consists of a yellow to grey, loosely compacted, pebbly sandy shell hash (Fig. 3.6). The siliciclastic component of litho-unit 7 consists of well sorted, medium-sized sand and rounded, and generally spherical greywacke pebbles. The skeletal mass is composed of reworked and often abraded macro-invertebrates including a mixture of shelf to intertidal molluscs. In decreasing abundance they are: A. stutchburyi; Stiracolpus sp.; Z. zelandica; Z. lutulentus; T. spissa; P. finlayi; C. gemmulata; N. hartvigiana; S. symmetricus; A. depressa; Z. acinaces; M. striata; X. pleibeius; D. huttoniana; B. crassidens; M. dicatus; C. nassoides; Cellana sp.; Aeneator sp.; and, Buccinulum sp.

Litho-unit 7 is interpreted as representing an inner shelf environment based on the well preserved shallow marine faunal content. Lithologies that are similar to Facies SL described in this study, which have high carbonate content, commonly indicate terrigenous starved conditions ( $c f$. Abbott and Carter, 1994; Naish and Kamp, 1997a: Mitchell, 2001). Such environments commonly develop on the inner shelf from an increase in accommodation space on-land that traps terrigenous sediment in proximal areas on the coastal plain causing it to bypass the shoreface (i.e. as the shoreface sediment wedge migrates landward during a relative sea level rise) (Abbott, 1997; Coe et al., 2003). The well preserved estuarine fauna in litho-unit 7, consisting largely of $A$. stutchburyi, suggests there were expansive estuaries present in adjacent environments during its deposition, which may have acted as sediment sinks. Since it is generally agreed estuaries form during coastal submergence (e.g. Curray, 1964; Boyd et al., 1992), it can be postulated Facies SL represents a period of relative sea level rise. 


\subsubsection{Facies SG - Dark grey to brown shelly gravel}

Facies SG refers to litho-units 11 and 17 located between 201-202m and 145-146m depths (Fig. 3.1), which consists of a dark grey to brown poorly sorted sandy shelly gravel (Fig. 3.6). The clasts composing the gravel consist of rounded to very wellrounded spherical greywacke pebbles, which have a medium sized poorly sorted sandy matrix. The fossil content consists of detrital fragments of bivalves and gastropods, and only whole specimens of bivalves $Z$. acinaces and/or $P$. finlayi were identified.

The two litho-units containing Facies SG are interpreted as representing a high energy inner-shoreface environment based on the presence of well rounded spherical greywacke pebbles and shell fragments. Similar shelly gravel lithologies have been found to occur at the base of uplifted marine terraces in Wanganui Basin, which have been interpreted as transgressive lag deposits that formed upon wave-cut platforms (Pillans, 1983; Pillans, 1994). These deposits formed from ravinement of the inner shelf that was associated with the landward advance of an erosional shoreface during a relative sea level rise (Saul et al., 1999).

\subsubsection{Facies $\mathrm{S}$ - Grey to brown, fine-grained, barren, well sorted sand}

Litho-units consisting of 4-5m thick grey to brown, unconsolidated, barren sands are assigned to Facies $\mathbf{S}$ (Figs. 3.1 and 3.5). The mineralogy of the sands is dominated by quartz, feldspar, muscovite, biotite, hypersthene, hornblende, and colourless glass shards. The high proportion of mica and other volcaniclastic minerals suggests a prominent coastally-derived littoral source for the grains as they have a similar composition to Plio-Pleistocene shallow marine and volcanic beds which lie north of the region (e.g. Holgate, 1985). 

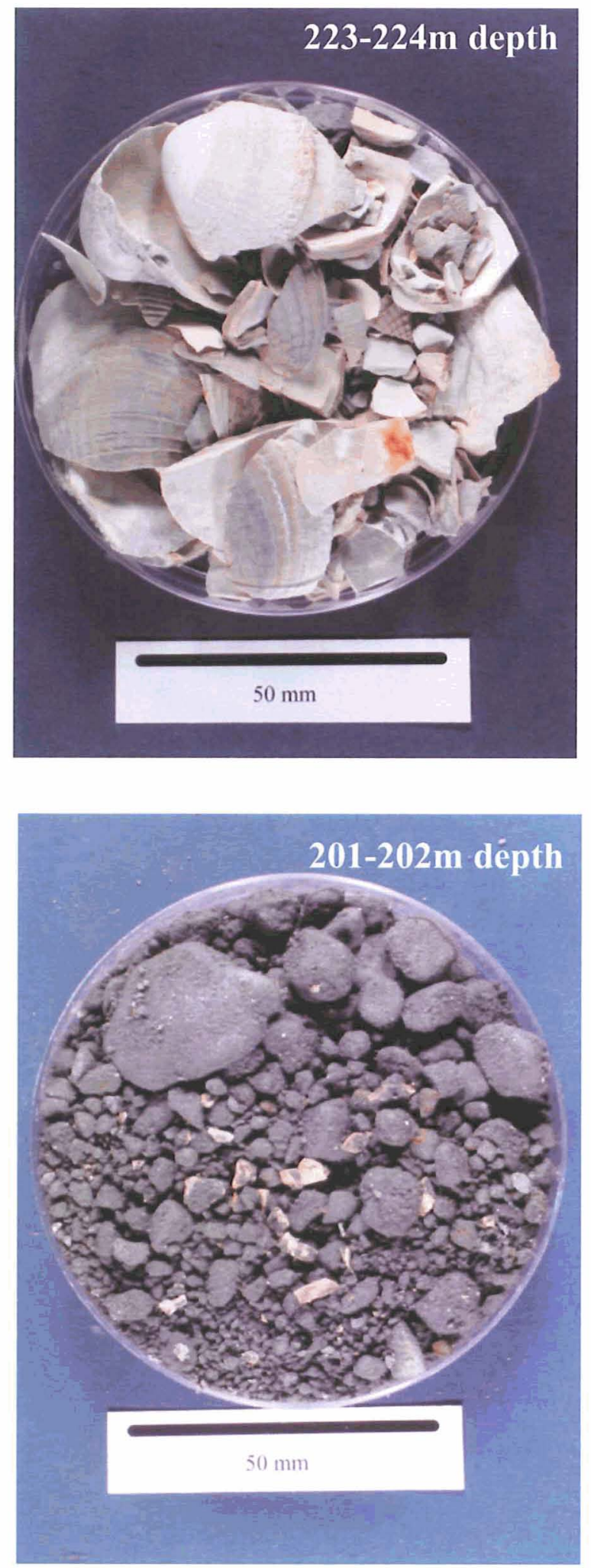

Figure 3.6: Photographs of lithologies consisting of Facies SL (top) and SG (bottom). Facies SL (Sample 223-224m depth) is shell rich and formed on a terrigenous starved inner shelf environment (i.e. Mid cycle shell bed of Abbott, 1997). Facies SG (sample 201$202 \mathrm{~m}$ depth) is a shelly gravel which formed in a high-energy innermost shoreface environment possibly upon a wave-cut platform. 
Grains from the Wanganui and Taranaki Regions were most likely sourced by longshore currents that move in a southward direction along the Wanganui Bight, which transport sediment deposited at the coast by rivers (Lewis, 1979a).

The sands either consist of very well sorted fine sand grains or well sorted fine to medium sized sand grains. Using values of sorting and skewness determined from grainsize analysis (App. C) the facies has been subdivided into two sub-facies; one dune sand (Sd), and the other beach sand (Sb) (Fig. 3.7). According to Friedman (1961) dune sands are generally slightly better sorted than beach sands and have a positive skewness whereas beach sands generally have a negative skewness.

\subsubsection{Facies IGM - Blue coarse-grained gravel and green mud units}

Facies IGM refers to strata between $147-171 \mathrm{~m}$ depth (litho-unit 16) (Fig. 3.1) that consists of interbedded blue, barren, coarse-grained and moderately well sorted gravel, and green poorly sorted, barren mud deposits (Fig. 3.8). The clastic component of the gravel beds consist of sub-angular to rounded greywacke pebbles and cobbles, up to $10 \mathrm{~cm}$ in diameter, which have a quartz-rich silty sand matrix. The texture of the mud beds range from silty clay to clayey silt and some contain rare rounded greywacke pebbles.

The interbedded gravel and mud deposits comprising litho-unit 16 are interpreted as representing a fluvio-deltaic environment. The presence of sub-rounded to sub-angular greywacke clasts within the gravel beds indicates fluvial sorting and transportation processes (e.g. Miall, 1978; Blair and MacPherson, 1994). The clast texture and composition is similar to Marton and Ohakean Alluvium that compose uplifted Pleistocene river terraces in the Horowhenua (e.g. Barnett, 1984), and were probably deposited from high flowing rivers eroding the axial range where greywacke is exposed up to $1500 \mathrm{~m}$ above sea level. 
Plot of standard deviation vs. skewness for sands found in Horowhenua District

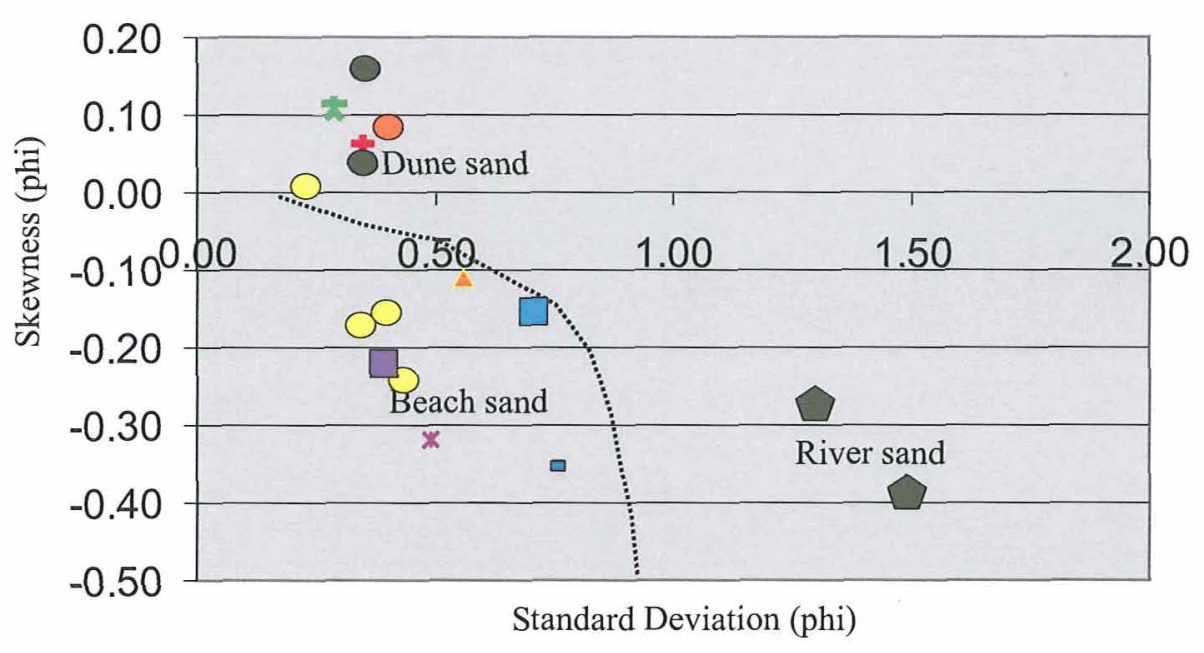

KNOWN SANDS
$\square$ Modern river sand* (Otaki)
$\square$ Modern beach sand* (Otaki)
$\square$ Otaki Formation (beach sand)
Koputaroa Dune sand*
Foxton Dune sand*
Otaki Formation (dune sand)
(S23C 9367/4712)

SAND UNITS IN LEVIN BOREHOLE

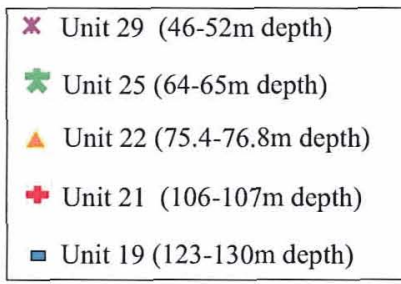

* Data courtesy of R. M. Hawke

Beach and dune sand range fields from Friedman (1961) (dotted line)

Note: Foxton dune sand often has a negative skewness which has been regarded as reflecting sediment source rather than depositional processes (Shepherd, 1985).

Figure 3.7: Determination of sub-facies $\mathrm{Sd}$ and $\mathrm{Sb}$ from litho-units consisting of fine well sorted barren sand deposits using grainsize characteristics. 

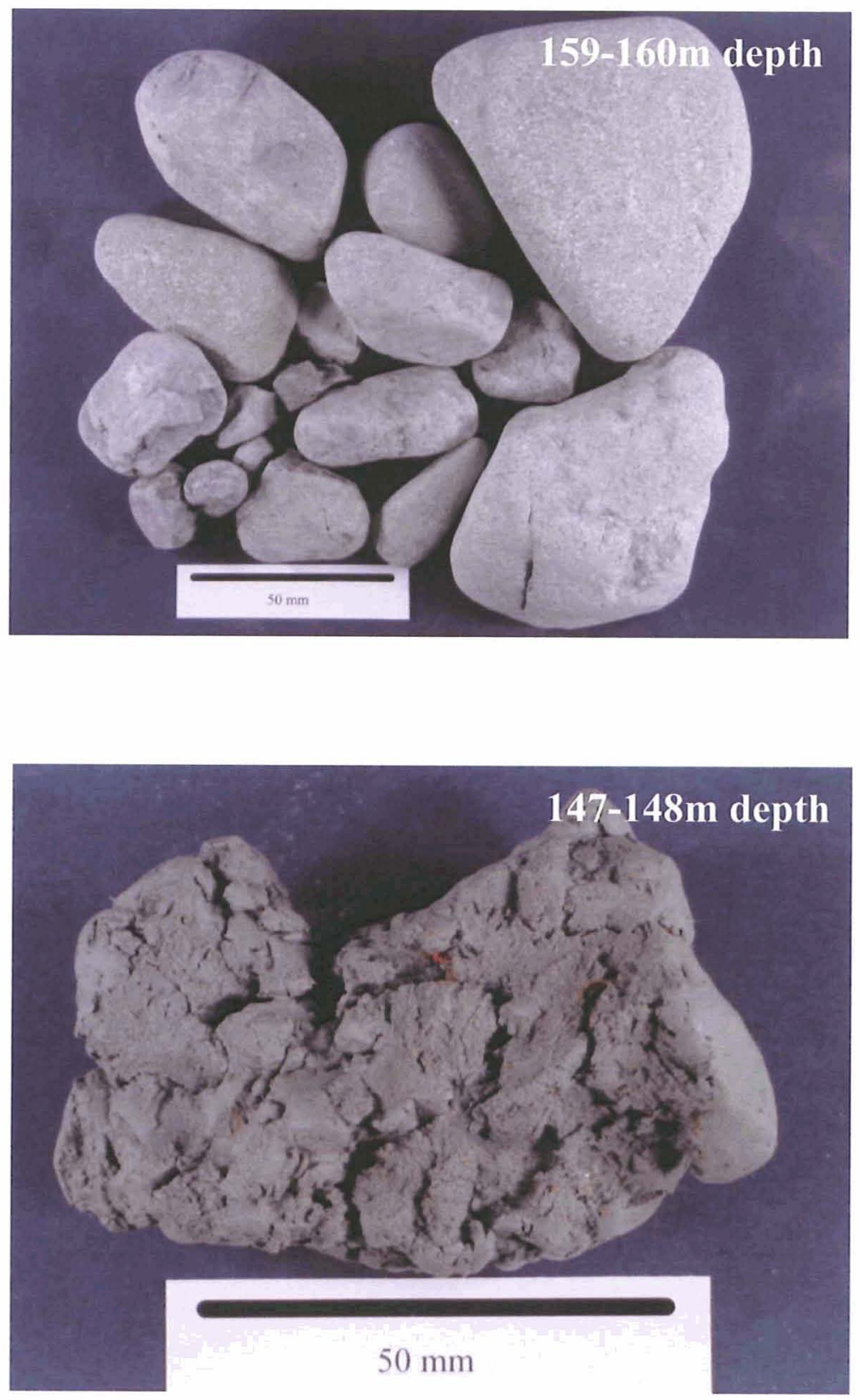

Figure 3.8: Photographs of the two litho-unit members of Facies IGM -

Interbedded gravel and mud. Top is the gravel component, which consists of sub rounded to sub-angular greywacke pebbles and cobbles (sample 159$160 \mathrm{~m}$ depth). Bottom is the mud component, which is composed of grey to green, massive, poorly sorted, barren silty clay (sample 147-148m depth). 
Abundant fine-grained particles within the mud interbeds indicates a low energy and possible sub-aqueous depositional environment (cf. Facies Fm - Miall, 1978). In addition, the lack of bedforms and calcareous fossil material suggests a non-turbid and non-marine environment (e.g. Boggs, 1995). Therefore mud interbeds most likely represent lake or pond deposits, which formed upon the alluvial plain.

\subsubsection{Facies $\mathbb{Z}$-brownish grey, laminated, carbonaceous silt}

Litho-units $23,25,27,31,33$, and 35 containing brownish grey, fine-grained, organicbearing, sandy silt or clayey silt deposits are assigned to Facies $\mathbf{Z}$ (Fig. 3.1). The silts units are generally composed of thin parallel- or ripple-laminations containing dark brown silt and light grey sand or mud beds. Fossils encountered in these units consist of in situ roots, nodules, stems, wood, and charcoal pieces (Fig. 3.9).

Silt units containing Facies $\mathbf{Z}$ are generally thin, on average between $2-3 \mathrm{~m}$ thick, and are interpreted as representing a waning fluvial overbank floodplain deposit ( $c f$. Facies Fl - Miall, 1978). Deposition most likely occurred in low energy, partially vegetated oxbows or swamps that formed in abandoned channels or on gravel terraces of rivers in the region.

\subsubsection{Facies G - Brown, coarse grained, gravel}

Facies Grefers to litho-units consisting of brown, coarse-grained, poorly sorted gravel deposits (Figs. 3.1 and 3.10). The clastic component generally consists of sub-rounded to sub-angular fragments of greywacke, quartz, and argillite, which are bounded by a brown, coarse-grained, quartz-rich silty sand matrix. Some litho-units containing this facies contain strongly weathered clasts that show evidence of abrasion (e.g. unit 36), other clasts have a smooth texture and have retained a fresh blue colouring (e.g. unit 20). Large pieces of wood and other organic fibrous material were commonly found in units containing Facies G (Fig. 3.10). 

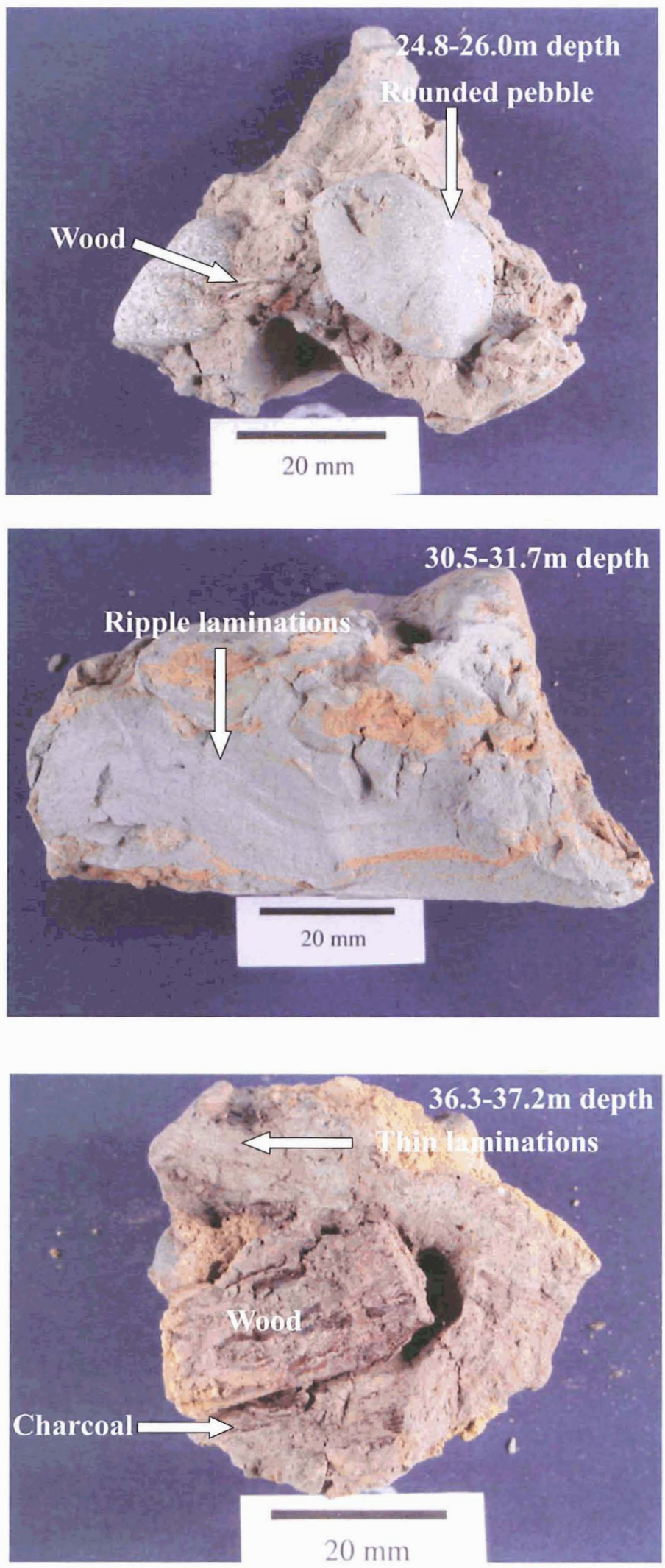

Figure 3.9: Photos of some samples comprising Facies $\mathbf{Z}$ - brownish grey planarto ripple-laminated carbonaceous silt. Also shown are pebbles, wood chips, and charcoal, which are common in these units. 

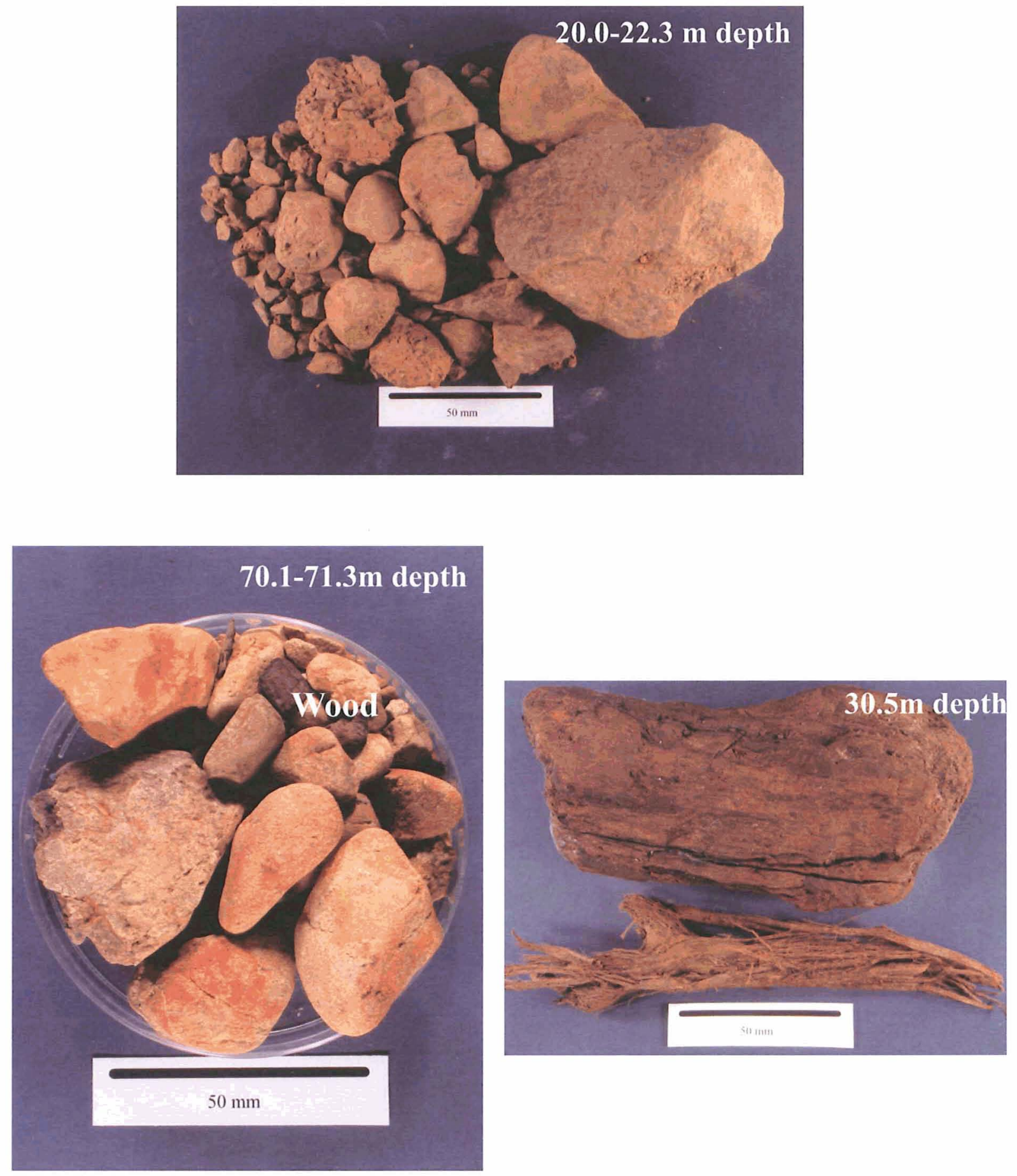

Figure 3.10: Photographs of a range of units assigned to Facies G - Brown coarse-grained gravel with often abraded angular to sub-rounded greywacke clasts. Also shown are wood pieces that were common in these units including a large piece of wood that was retrieved from $30.5 \mathrm{~m}$ depth. A similar piece from the same sample was radiocarbon dated at $>40 \mathrm{ka}$ BP $(\mathrm{Wk}-13830)$. 
Litho-units assigned to Facies $\mathbf{G}$ have a variable thickness (between 5-23m thick), and are on average $10 \mathrm{~m}$ thick. They are interpreted as representing gravel braided river channel, alluvial plain, or terrace deposits ( $c f$. Facies Gm - Miall, 1978). The gravels are probably not fan deposits as a large proportion of clasts show some degree of roundness (frequently sub-rounded to sub-angular), whereas fan gravels are mainly angular ( $c f$. Blair and McPherson, 1994). However, the absence of any rounded clasts in these units suggests transportation probably occurred either not far from origin or was rapid. The sediments are generally composed indurated sandstone and mudstone (greywacke) that are similar in composition to Torlesse Terrane rocks, which outcrop in the Tararua Range (e.g. Foley et al., 1988). Therefore Facies G most likely represents channel or terrace deposits from nearby rivers, such as the Ohau River or Koputaroa Stream, which have their headwaters in the Tararua Range.

\subsection{SUMMARY OF STRATIGRAPHY AND FACIES ANALYSIS}

The Levin borehole sequence has been subdivided into 36 lithological units. These were subdivided further into nine lithofacies units on the basis of like-lithological characteristics, which were then used to make generalisation about past environmental conditions (Table 3.2). In summary, the lower 148m (130-278m depth) of the borehole contains marine and paralic deposits. Facies analysis indicates deposition was related to a range of marginal marine (estuarine), shallow marine (shoreface), to inner-shelf environments. The top $130 \mathrm{~m}$ of the borehole is composed of thick gravel units are separated by thinner silt or sand deposits. Facies analysis suggests the gravel deposits represent coarse-grained fluvial channel, bar, or terrace deposits and silt or mud deposits represent floodplain sediment. Grainsize analysis has revealed sand deposits are composed of dune and beach sand sediment. 


\section{CHAPTER 4 \\ MICROFOSSIL PALEOECOLOGY}

\subsection{INTRODUCTION}

Microfossil paleoecology was used to refine paleoenvironmental interpretations made from lithofacies analysis for strata under this study. This is because similar facies can sometimes form in different environments and these need to be distinguished between. For example fossiliferous silty sand deposits (Facies FZS) can form in both offshore marine and estuarine environments (e.g. Reinson, 1992; Swift and Thorne, 1991) and microfossil paleoecology can help distinguish between these.

Microfossil studies were restricted to foraminifera contained in marine litho-units 1-18 that comprise the lower $150 \mathrm{~m}$ of the borehole. Paleoecological interpretations involved comparing fossil foraminiferal assemblages from this study to modern assemblages from the New Zealand region (e.g. Hayward, 1982; Perrett, 1990; Hayward and Hollis, 1994, Hayward et al., 1996; Hayward et al., 1997a; Hayward et al., 1997b). It also involved an assessment of possible post mortem affects (i.e. Hayward et al., 1999). Interpretations were made using cluster analysis, a technique which groups taxa into an order of similarity to allow for interpretations of their past environments to be assessed by qualitative comparison with modern distributions (Birks and Birks, 1980). Recent studies have shown patterns of foraminiferal assemblages are more significant in determining paleoecology than the distribution of key diagnostic taxa (e.g. Haywick and Henderson, 1991; Naish and Kamp, 1997b).

\subsubsection{Foraminiferal taphonomy}

Due to their small size, foraminifera are prone to a range of post mortem affects that may affect fossil assemblages. For example, foraminifera have the potential to be reworked by waves and currents in nearshore environments. This may involve tests being washed into adjacent environments by strong waves and currents soon after death producing mixed assemblages (Hayward and Hollis, 1994), or reworking from ancient 
sources to modern environments (Birks and Birks, 1980). However, the amount of mixing depends on tidal current strength and therefore tidal range. Fortunately, tides are largely micro-meso in New Zealand and are likely to cause only moderate mixing compared to other parts of the world (Hayward et al., 1999). Alternatively, tests maybe lost producing lower then expected species diversity, which affects subsequent paleoenvironmental interpretations. Loss of tests commonly occurs in high energy environments through abrasion of weakly cemented tests, or by chemical changes on the sea floor during deposition (Hayward et al., 1999).

\subsection{PROCESSING OF FORAMINIFERA}

Samples containing calcareous or carbonaceous material were processed for foraminifera (methods outlined in App. D). Individual tests were picked, mounted, identified, and counted on a gummed slide using a binocular microscope. Approximately 100 foraminiferal species were picked from each sample. This number has proven to provide a sufficiently accurate assessment of faunal composition for use in identifying shallow marine associations (e.g. Hayward and Hollis, 1994; Hayward et al., 1997b; Naish and Kamp, 1997b). Planktonic species were also picked although they were not included in the final count as paleoecology of benthic foraminifera was the main focus of this investigation.

\subsubsection{Raw data}

The raw data consisted of counts of approximately 1900 individual foraminifera representing 46 separate species from 21 samples (Table 4.1; App. D). Of the 21 samples processed, two were barren (samples 76-77m and 123-130m depths), and one had a low count of only 60 tests (sample 259-260m depth). 


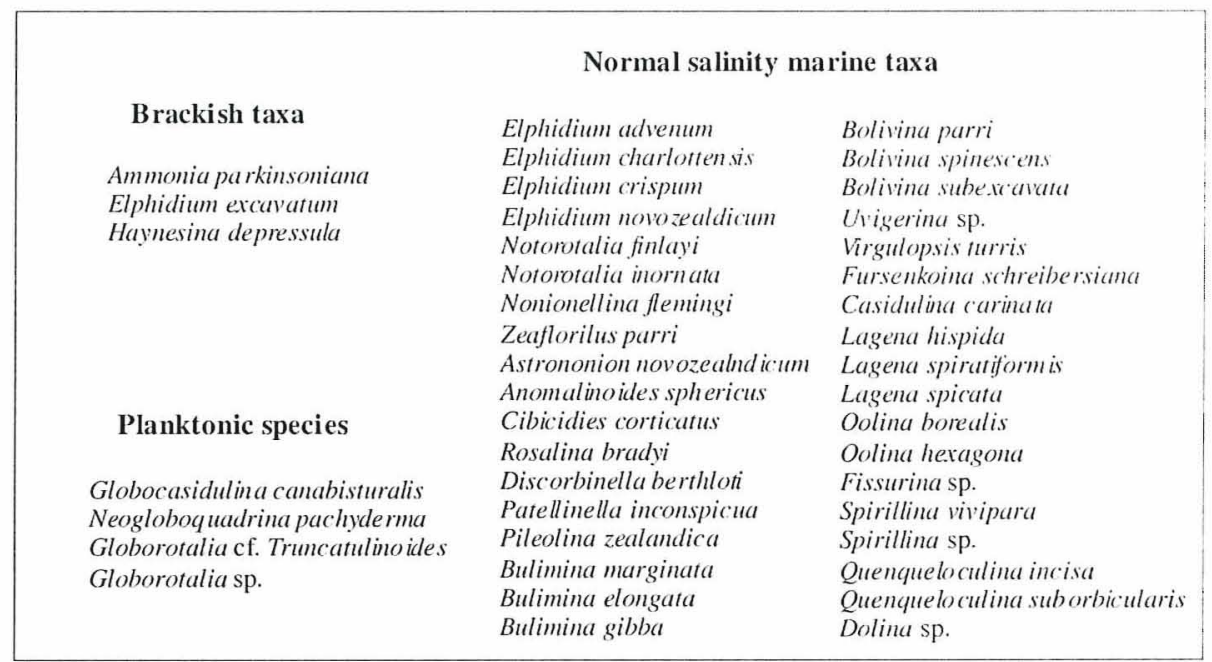

Table 4.1: List of foraminiferal species found within the Levin borehole (environments after Hayward et al., 1999) (App. D).

\subsubsection{Species diversity}

Species diversity was calculated for each sample from full taxonomic census using Fisher Alpha Index $(\boldsymbol{\alpha}=N(\mathbf{1 - x}) / \mathbf{x})) . N$ refers to the number of individuals in a sample and $\mathbf{x}$ is a constant related to the number of species. Here, values of $\boldsymbol{\alpha}$ were read directly off a tabulated graph (Murray, 1991, p.319). In general, brackish environments with high tidal exposure have relatively low species diversity ( $\alpha=1-3.5)$. More ecological stressed environments, such as wave-dominated shoreface environments, may also produce low diversity faunas as abrasion causes loss of tests. There is a general trend of increasing diversity from brackish faunas to normal salinity faunas $(\alpha=6.5-21)$ and with increasing water depth (to where $\alpha>10$ ) (Hayward and Hollis, 1994; Hayward et al., 1997a). Post- and syn-depositional mixing of faunas may also produce abnormal high diversity values such as near the entrances of harbours and inlets (e.g. Hayward and Hollis, 1994; Hayward et al., 1999).

\subsection{CLUSTER ANALYSIS AND FORAMINIFERAL SAMPLE ASSOCIATIONS}

To create meaningful clusters, taxa at the species level that contributed to less than $4 \%$ of the total population was removed so analysis could be based on the most common and abundant taxa (cf. Naish and Kamp, 1997b; Hayward et al., 1999). In addition, planktonic foraminifers were not included in the matrix as the strategy of the analysis 
was to identify key benthic associations within the data set. The pre-treatment of the data involved eliminating 29 species that contained insufficient abundances, leaving 17 benthic taxa (Fig. 4.1) and 19 samples (Fig. 4.2).

The data matrix was standardized to $100 \%$ and analysed using unweighted pair group Q-mode cluster analysis using arithmetic averages of Bray-Curtis distance matrix. A dendrogram classification was produced from which sample associations were selected (Figs. 4.2 and 4.3). Cluster analyses were computed using the MVSP version 3.1 statistical package and results are noted in Appendix D (Kovach, 2003).

Six sample associations were visually identified from the dendrogram (Fig. 4.2), which are labelled according to the most prominent species within them; A (Ammonia parkinsoniana), $\quad \mathrm{AE} \quad$ (A. parkinsonianalElphidium advenum), $\mathrm{AZ}$ (A. parkinsoniana/Zeaflorilus parri), $\mathbf{E}$ (Elphidium spp.), $\mathbf{N}$ (Notorotalia finlayi), and $\mathbf{Q}$ (Quinqueloculina incisa) (Fig. 4.3). These are compared to modern assemblages from the New Zealand region (Fig. 4.5).

\subsubsection{Association A: Ammonia parkinsoniana}

Sample association A is dominated by Ammonia parkinsoniana (87\%), with minor occurrences of Notorotalia finlayi, Haynesina depressula, and Elphidium advenum (each 3-6\%) (Fig.4.3). It is the most dominant assemblage in strata between 172-182m and 223-224m depth (Fig. 4.4).

Modern foraminiferal sample associations that are dominated by A. parkinsoniana (up to $95 \%$ mean relative abundance) occur in slightly brackish conditions in the intertidal to sub-tidal zones of New Zealand estuaries and middle inner areas of closed harbours and tidal inlets between mean sea level and mean low water (e.g. Hayward and Hollis, 1994; Hayward et al., 1996; Hayward et al., 1999). High concentrations of A. parkinsoniana has also been linked to organic nutrient rich muddy or sandy substrates in more ecologically stressed environments such as around stream mouths, which flood occasionally (Hayward et al., 1999). 


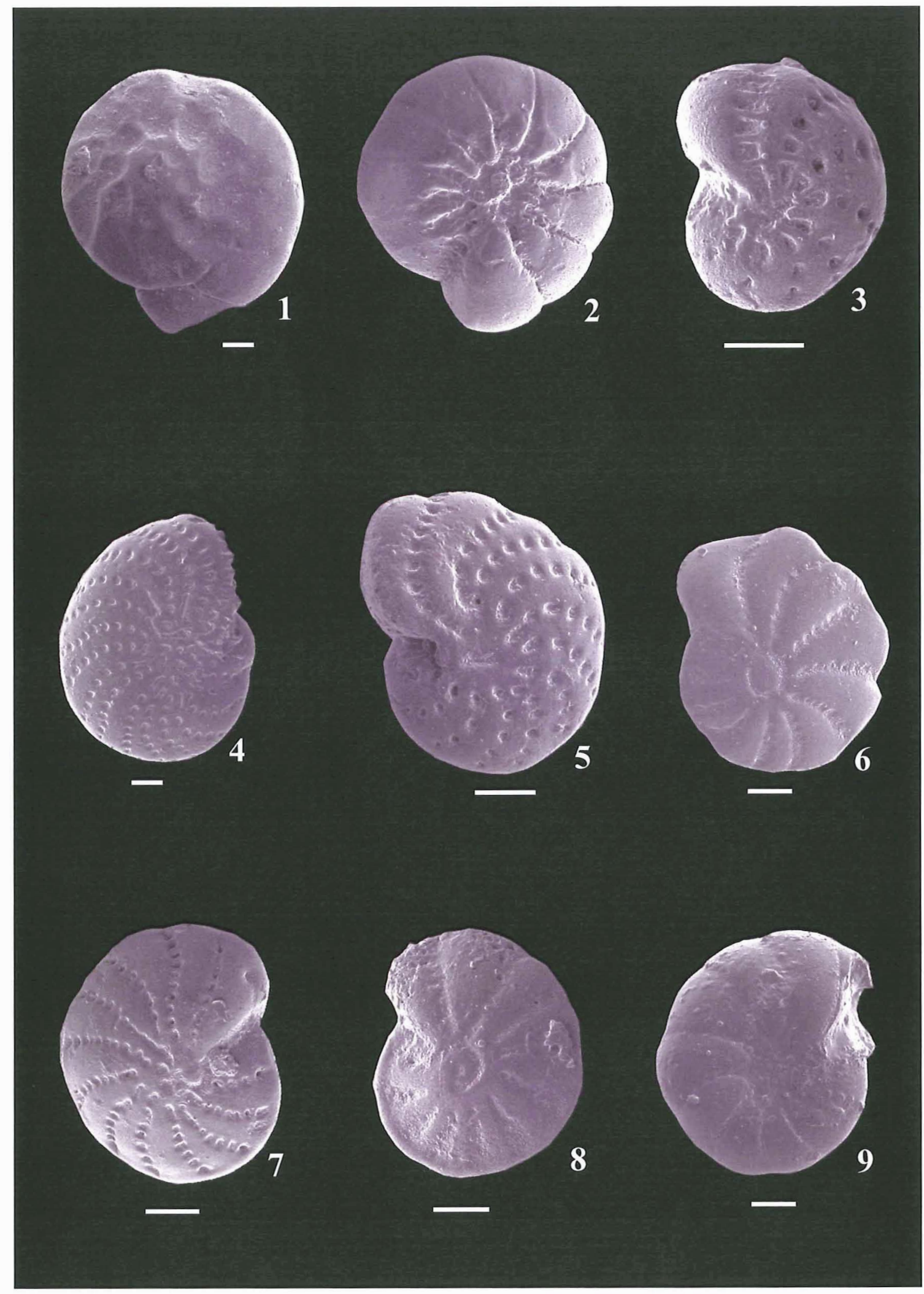

Figure 4.1: Scanning electron microscope $(3 \mathrm{kV})$ photographs of the characterising and more common foraminiferal species found in the Levin Borehole. 1-2 Ammonia parkinsoniana, sample 223-224m depth. 3 Elphidium advenum, sample 193-194m depth. 4 Elphidium excavatum f. willamsoni, sample 227-228m depth. 5 Elphidium excavatum f. Clavatum, sample 277-277.3m depth. 6 Elphidium advenum f. maorium, sample 247-248m depth. 7 Elphidium charlottense, sample 221-222m depth. 8 Elphidium crispum, sample 221-222m depth. 9 Haynesina depressula, sample 191-192m depth.

Scale bars equal 100 microns. 


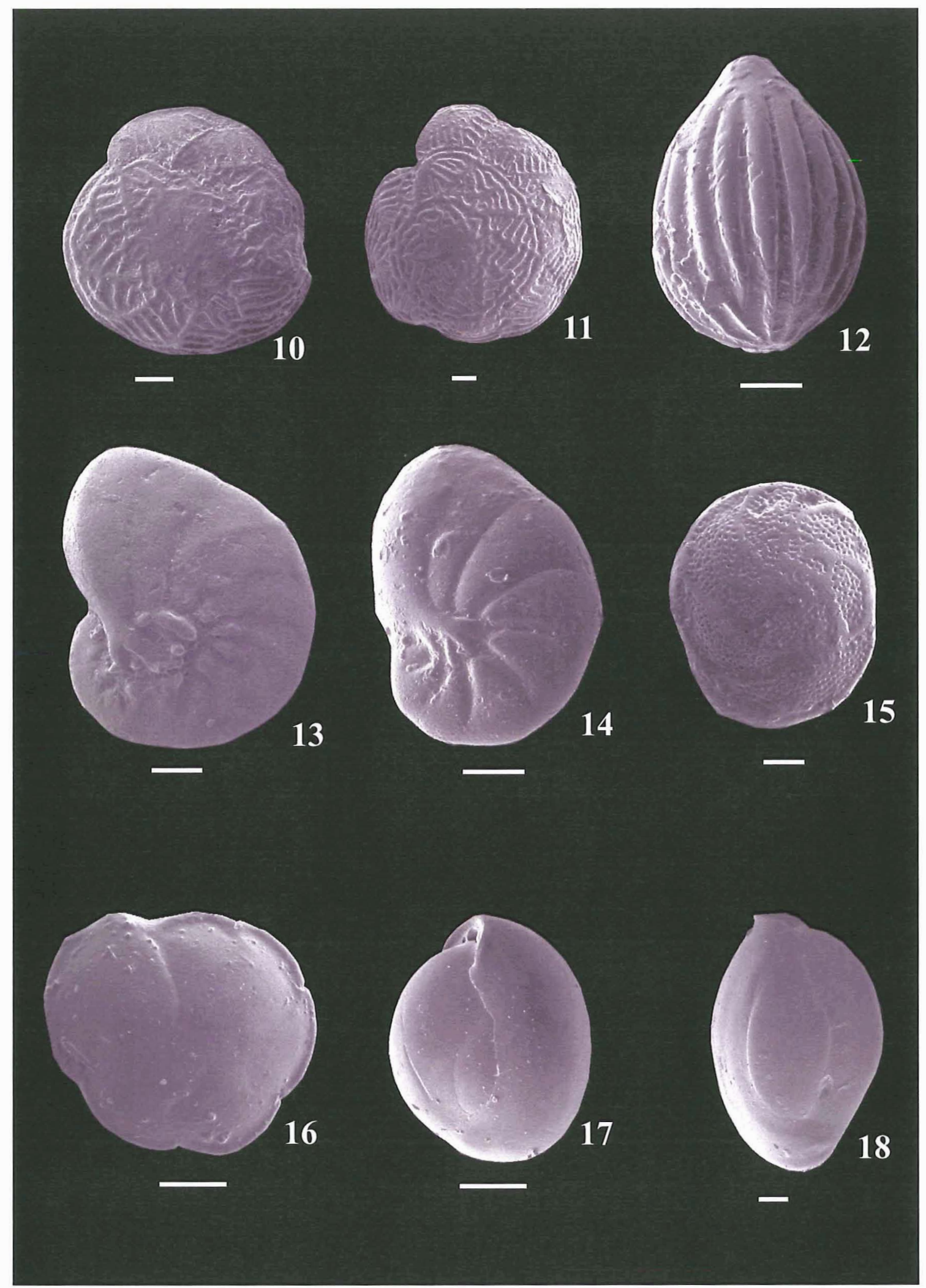

Figure 4.1 continued: 10 Notorotalia finlayi, sample 241-242m depth. 11 Notorotalia inornata, sample 212-213m depth. 12 Oolina borealis, sample 221-222m depth. 13 Zeaflorilus parri, sample 131-132m depth. 14 Nonionellina flemingi, sample 241-242m depth. 15 Rosalina bradyi, sample 241-242m depth. 16 Discorbinella bertheloti, sample 247-248m depth. 17 Quinqueloculina suborbicularis, sample 247-248m depth. 18 Quinqueloculina incisa, sample 248-249m depth. Scale bars equal 100 microns. 


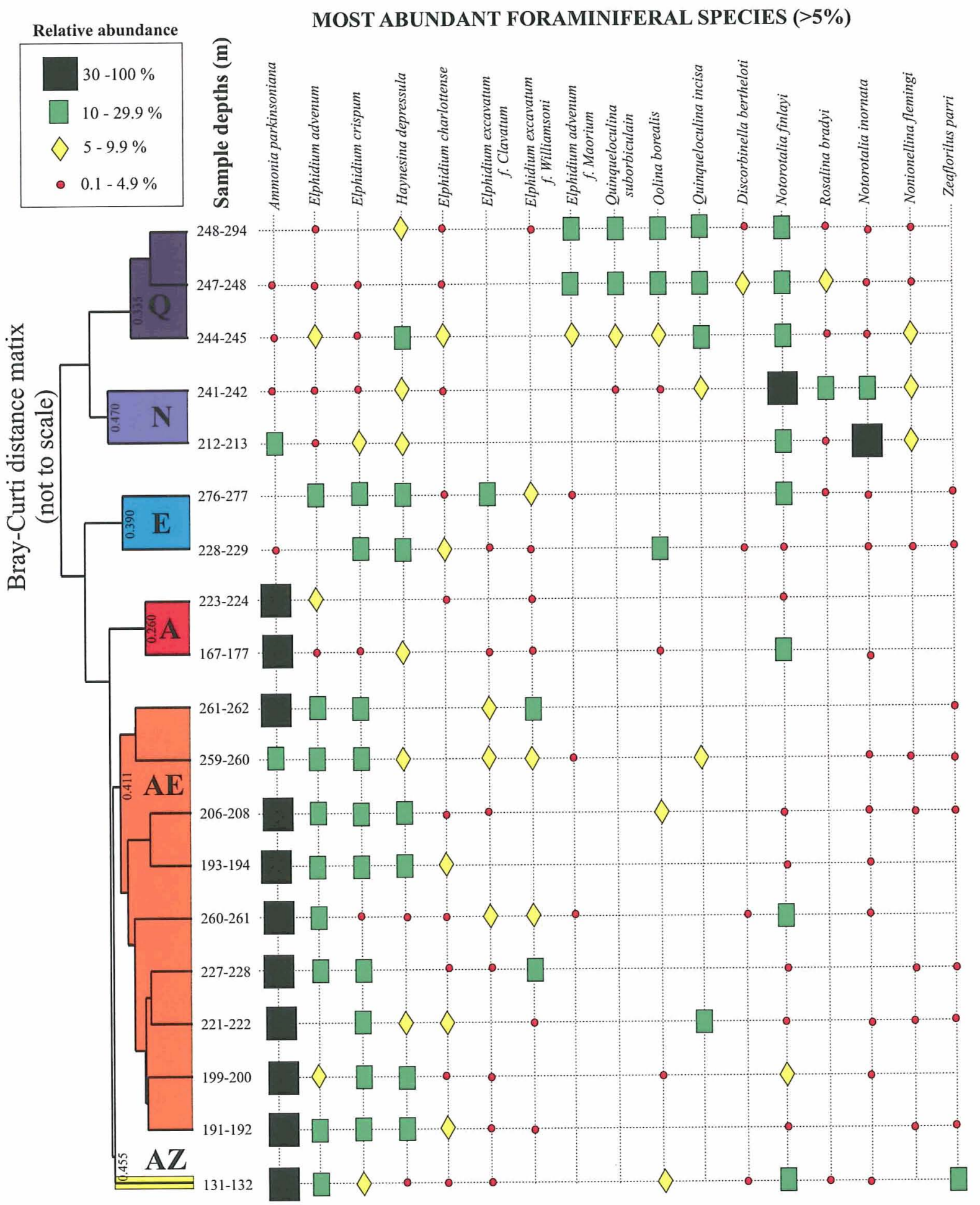

Figure 4.2: Dendrogram classification of Levin borehole Foraminiferal sample associations produced by cluster analysis using Bray-Curtis distance matrix (Kovach, 2003). The six species associations were selected after inspection of the dendrograms. The relative abundance of the most abundant taxa is also summarised in the chart. 


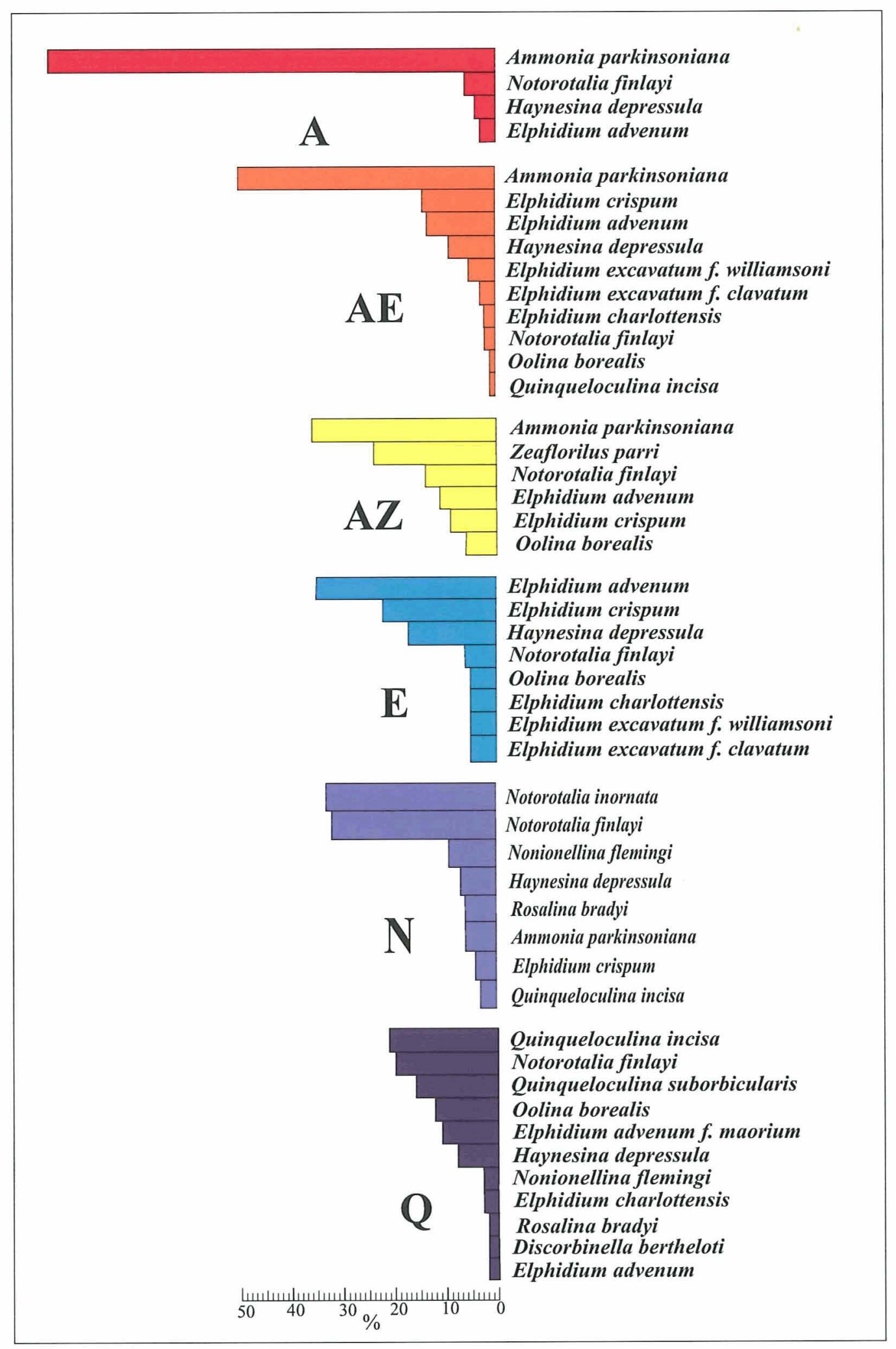

Figure 4.3: Histograms showing relative abundance of the most common ( $>5 \%)$ foraminiferal species present in each association identified from the dendrogram, Fig. 4.2. 


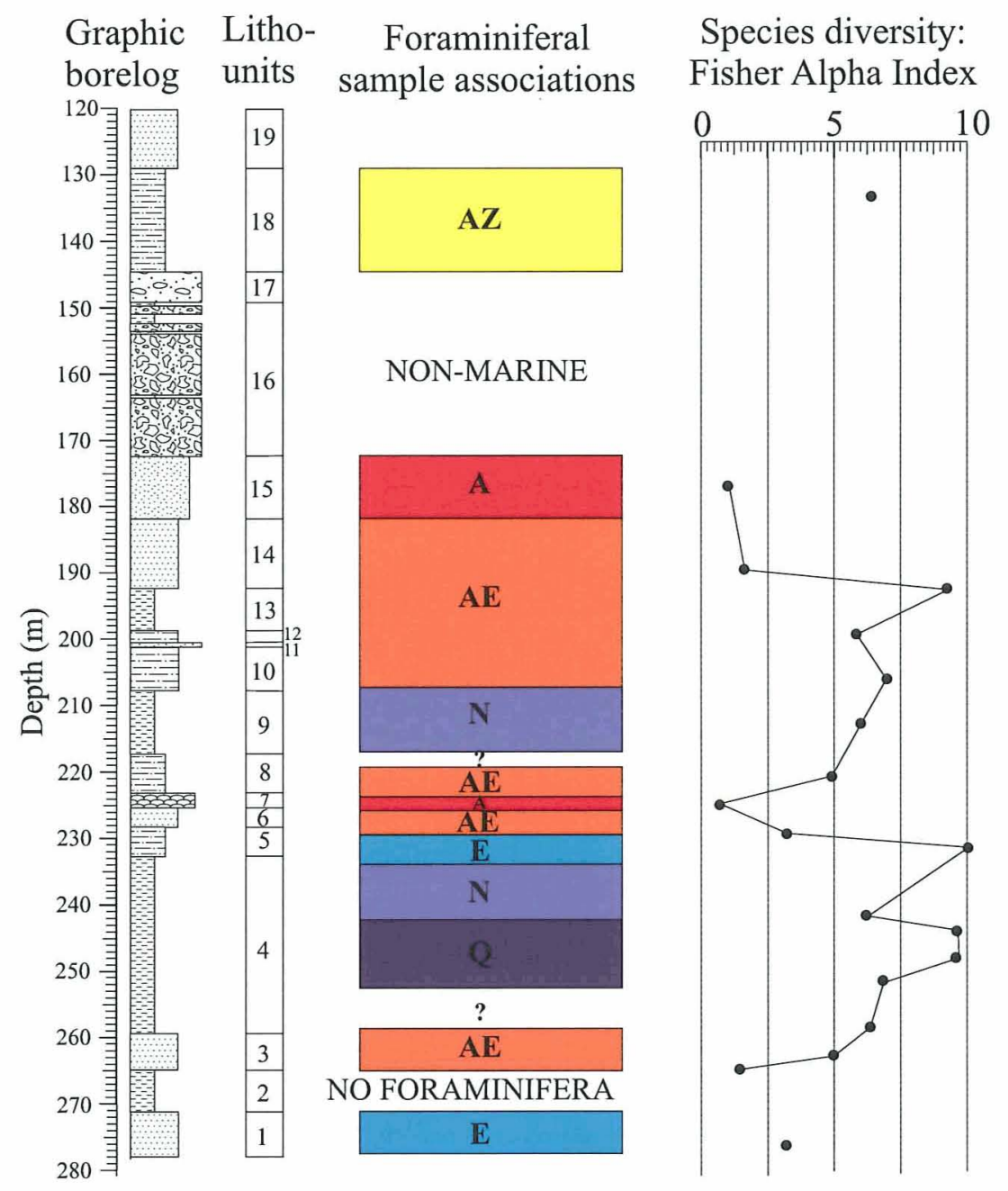

Figure 4.4: Species diversity values of Fisher Alpha Index and foraminiferal sample associations plotted against depth for lower 150m Levin borehole strata. (Refer to Fig. 3.1 for lithologies). 


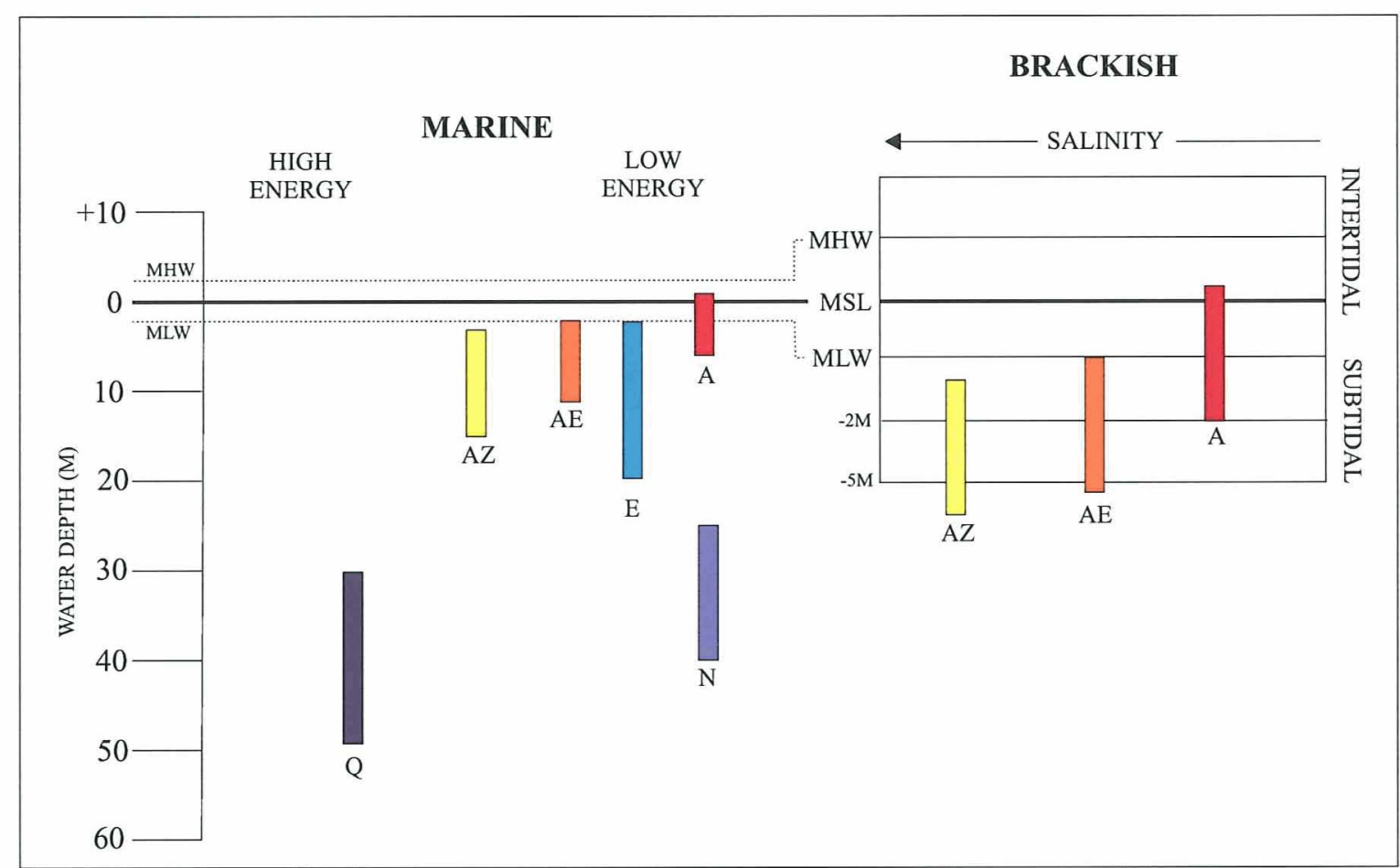

Figure 4.5: Distribution of the six brackish water and fully marine foraminiferal associations encountered in this study and their relationship to various environmental factors.

(MSL = mean sea level, MHW = mean high water, MLW = mean low water)

(after Hayward et al., 1999) 
Association A (this study) is interpreted to represent a slightly brackish subtidal estuarine environment in less than 2m water depth (cf. Hayward et cl., 1999) (Fig. 4.5). The sample from 176-177m depth contains well preserved tests of A. parkinsoniana and low species diversity $(\alpha=2)$, and is probably an in situ assemblage (Hayward and Hollis, 1994). The absence of salt marsh agglutinated foraminifera species in this sample may indicate the estuary was wave-dominated rather than tide-dominated or that these species have not been preserved (Dalrymple et al., 1992). The sample from 223$224 \mathrm{~m}$ has an extremely low species diversity $(\alpha=1)$ and the tests of A. parkinsoniana are highly abraded and broken, which may indicate a high-energy depositional environment where other less robust tests may have been lost through abrasion (Hayward et al., 1999).

\subsubsection{Association AE: Ammonia parkinsoniana/Elphidium spp.}

This sample association is dominated by Ammonia parkinsoniana (50\%), with subdominant Elphidium crispum (14\%), E. advenum (13\%), and Haynesina depressula (9\%). Also common are E. excavatum f. williamsoni, E. excavatum f. clavatum, and Notorotalia finlayi (each $<5 \%$ mean abundance) (Fig. 4.3). It is the most dominant assemblage within strata between 182-208m, 218-223m, 224-228m, and 258-264m depth (Fig. 4.4).

Modern foraminiferal sample associations containing Ammonia and normal salinity Elphidium species (each 25-50\%) have been found around the interface between truly brackish and truly marine conditions, such as around the mouth and lower stretches of estuaries and in the middle to upper reaches of enclosed harbours and bays ( $c f$. Marginal Marine Association of Hayward and Hollis, 1994). The association occurs both intertidally and sub-tidally in at least $12 \mathrm{~m}$ water depth and generally has high diversity ( $\alpha=2.3-25$ ) (Hayward and Hollis, 1994). A similar environment is interpreted for Association $\mathrm{AE}$ in this study (Fig. 4.5), although the varying proportions of brackish and normal salinity foraminifera suggests this association could represent either an estuarine or open marine environment. It is likely samples with higher species diversity $(\alpha>4)$ such as $191-192 \mathrm{~m}, 206-208 \mathrm{~m}, 221-222 \mathrm{~m}$, and 259-260m depth indicate an outer-most estuary or sub-tidal sheltered shoreface environment where normal salinity 
marine species have been mixed with brackish marine species. By contrast, samples with lower species diversity $(\alpha<4)$, such as $227-228 \mathrm{~m}$ and $262-263 \mathrm{~m}$ depth, indicate a brackish sub-tidal estuarine environment.

\subsubsection{Association AZ: Ammonia parkinsoniana/Zeaflorilus parri}

Association AZ is co-dominated by Ammonia parkinsoniana (36\%) and Zeaflorilus parri $(24 \%)$ with subdominant Notorotalia finlayi (14\%), Elphidium advenum (11\%), Elphidium crispum (9\%), and Oolina borealis (6\%) (Fig. 4.3). This sample association is only found within strata between $130-145 \mathrm{~m}$ depth (Fig. 4.4).

Modern foraminiferal sample associations from New Zealand containing large amounts of $A$. parkinsoniana and $Z$. parri are commonly found within the entrances to large harbours or inlets (Hayward and Hollis, 1994). The reason being that although Z. parri strictly inhabits shallow ( $<20 \mathrm{~m}$ depth) exposed wave-dominated coastal environments (Lewis, 1979b; Perrett, 1990; Hayward and Hollis, 1994; Hayward et al., 1996; Hayward et al., 1997b) upon its demise it often gets transported by waves and currents into harbour and inlet mouths where it may get mixed with brackish marine species such as Ammonia and Elphidium (each comprising 4-10\%) (Hayward and Hollis, 1994). Therefore Association $\mathbf{A Z}$ best represents a shallow sub-tidal environment within the outer part of an estuary near a major channel or entrance, in about 5-15m water depth, where mixing of fully marine and marginal marine species has occurred (cf. Hayward and Hollis, 1994) (Fig. 4.5). A species diversity of $\alpha>6$ is high for a brackish water association and suggests a mixing of brackish and normal salinity foraminiferal assemblages (cf. Hayward et al., 1999).

\subsubsection{Association E: Elphidium spp.}

Association $\mathbf{E}$ is co-dominated by Elphidium advenum (35\%), E. crispum (22\%), and Haynesina depressula (17\%). Also common are Notorotalia finlayi, E. excavatum $f$. clavatum, E. excavatum f. williamsoni, E. charlottensis, and Oolina borealis (each 5-6\% mean abundance) (Fig. 4.3). It is the most dominant assemblage found within strata between 228-232m and 270-278m depth within the Levin borehole (Fig. 4.4). 
Modern sample associations that are dominated by Elphidium species generally occur in moderately sheltered sandy sub-tidal shallows in bays in or near entrances to deep harbours or inlets in less than 20m water depth (e.g. Hayward, 1982; Hayward et al., 1994; Hayward et al., 1997a; Hayward et al., 1999). Therefore Association E (this study) most likely represents a sandy bottomed sub-tidal beach or shoreface within a sheltered bay in about $20 \mathrm{~m}$ water depth (Fig. 4.5). Fisher Alpha Index values for modern associations dominated by Elphidium advenum are generally around 10 (Hayward et al., 1999) that agree with that calculated for sample 228-229m depth. However, sample 276-277m depth only has a Fisher Alpha Index of only 3 indicating tests may have been lost through either an abrasive depositional environment or post depositional winnowing (Hayward et al., 1999).

\subsubsection{Association N: Notorotalia inornata/Notorotalia finlayi}

Association $\mathbf{N}$ is co-dominated by Notorotalia inornata (33\%) and N. finalyi (32\%), with sub-dominant Nonionellina flemingi (9\%), Haynesina depressula (7\%). Also common are Ammonia parkinsoniana, Rosalina bradyi, Elphidium crispum, and Quinqueloculina incisa (each 3-6\% mean abundance) (Fig. 4.3). It is the most dominant assemblage within strata between 208-218m and 232-244m depth within Levin borehole (Fig. 4.4).

Notorotalia species have their greatest occurrences within deep sheltered quiet marine bays and inlets around New Zealand (Hayward et al., 1999). Similarly, modern sample associations that are dominated by $N$. finlayi and $N$. flemingi (up to $25 \%$ ) occur in deep (10-40m water depth), muddy, oxygen deficient enclosed waterways in southern and central New Zealand (e.g. Hayward et al., 1994; Hayward et al., 1997b). Fossil assemblages dominated by $N$. finlayi have also been found in ancient inner- to middleshelf strata (e.g. Naish and Kamp, 1997b). Therefore it is almost certain that Association $\mathbf{N}$ (this study) represents a deep, anoxic part of a quiet bay or inner shelf in about 25-40m water depth (Fig. 4.5). High species diversity values $(\alpha>10)$ for samples containing association $\mathbf{N}$ agrees with a deep marine setting (e.g. Hayward et al., 1999). 


\subsubsection{Association Q: Quinqueloculina incisa}

Association $\mathbf{Q}$ is co-dominated by Quinqueloculina incisa (21\%), Notorotalia finlayi (20\%), and Q. suborbicularis (16\%), with subdominant Oolina borealis, Elphidium advenum $f$. maorium, and Haynesina depressula (8-12\% mean abundance). Also common are Elphidium charlottensis, Nonionellina flemingi, Rosalina bradyi, Discorbinella bertheloti, and Elphidium advenum (2-3\% mean abundance) (Fig. 4.3). This assemblage is only found within strata between $244-258 \mathrm{~m}$ depth within the Levin borehole (Fig. 4.4).

Modern foraminiferal sample associations dominated by Quinqueloculina have not been documented from around the New Zealand region, although an informal biofacies containing both $Q$. incisa and $N$. finlayi has been noted living in $35 \mathrm{~m}$ water depth offshore from the Kapiti Coast in southwest North Island (Perrett, 1990). In addition, Q. incisa and $Q$. suborbicularis are the most common foraminiferal species found between 20-50m water depth on wave-dominated coastlines and sheltered fully marine inlets around New Zealand (e.g. Lewis, 1979b; Hayward, 1986; Hayward et al., 1999). It is therefore postulated that Association $\mathbf{Q}$ in the borehole strata represents an inner-shelf environment in about $30-50 \mathrm{~m}$ water depth offshore from a wave-dominated coastline (Fig. 4.5). High species diversity values $(\alpha>9)$ for samples containing association $\mathbf{Q}$ agrees with this interpretation (cf. Hayward et al., 1999).

\subsection{SUMMARY AND APPLICATION OF MICRO-FOSSIL PALEOECOLOGY}

In summary, 19 samples taken from between $120-277 \mathrm{~m}$ depth in the Levin borehole have been grouped into 7 sample associations based on varying proportions of 17 benthic foraminiferal species. These associations are interpreted to represent a range of inner shelf (associations $\mathbf{Q}$ and $\mathbf{N}$ ), to shoreface (association $\mathbf{E}$ ), to brackish water environments (associations $\mathbf{A E}, \mathbf{A Z}$, and $\mathbf{A}$ ) based on foraminiferal content. Normal salinity sample associations $\mathbf{Q}, \mathbf{N}$, and $\mathbf{E}$ are dominated by Quinqueloculina, Notorotalia, and Elphidium species and are found within litho-units consisting of marine mud, silty sand, and sand. Microfossil paleoecology has refined the paleoenvironmental interpretations from facies analysis for these units (Fig. 4.6) 
For example sample association $\mathbf{N}$ is only found within Litho-units 4 and 9 consisting of blue-grey mud deposits, which are interpreted as representing an inner shelf environment based on sediment characteristics (i.e. Facies M). However, the large proportion of Notorotalia species in these deposits (association $\mathbf{N}$ ) has refined this interpretation to a deep, quiet, anoxic, muddy inner shelf or marine embayment (e.g. Hayward et al., 1997b; Hayward et al., 1999).

In contrast to normal salinity associations, interpretations made from brackish marine sample associations $\mathbf{A Z}, \mathbf{A E}$, and $\mathbf{A}$ sometimes differs from those made from facies analysis (Fig. 4.6). The discrepancy has been attributed to reworking or mixing of assemblages, which commonly occurs in shallow water environments due the influence of waves and currents (e.g. Hayward and Hollis, 1994; Hayward et al., 1999). For example, brackish water associations $\mathbf{A E}$ and $\mathbf{A Z}$ represent mixed faunal assemblages, but are still unique to a particular environment such as entrances or channels to harbours or estuaries where strong tidal currents have caused normal salinity and brackish water taxa to become mixed (e.g. Hayward and Hollis, 1994). For example, sample association $\mathbf{A Z}$ found within litho-unit 18 (Facies FZS), indicates an outer-estuarine environment for these deposits. Likewise, sample association $\mathrm{AE}$ occurs in fossiliferous fine well sorted sand (litho-units 3, 6, and 14) and fossiliferous silty sand deposits (litho-units 8, 10, and 12) that are composed of Facies FS and FZS respectively. The sandy litho-units containing Facies FS are interpreted as representing sub-tidal shoreface deposits, whereas silty sand litho-units consisting of Facies FZS represent outer-estuarine deposits (Fig. 4.6). Sample association AE has also been found in lithounit 13 that is composed of Facies M. Therefore this unit is best interpreted as being deposited in a tidal marine embayment, rather than an inner shelf environment deduced from sediment characteristics, which was sheltered from wave energy allowing finesized silt and clay particles to settle out (Fig. 4.6). 


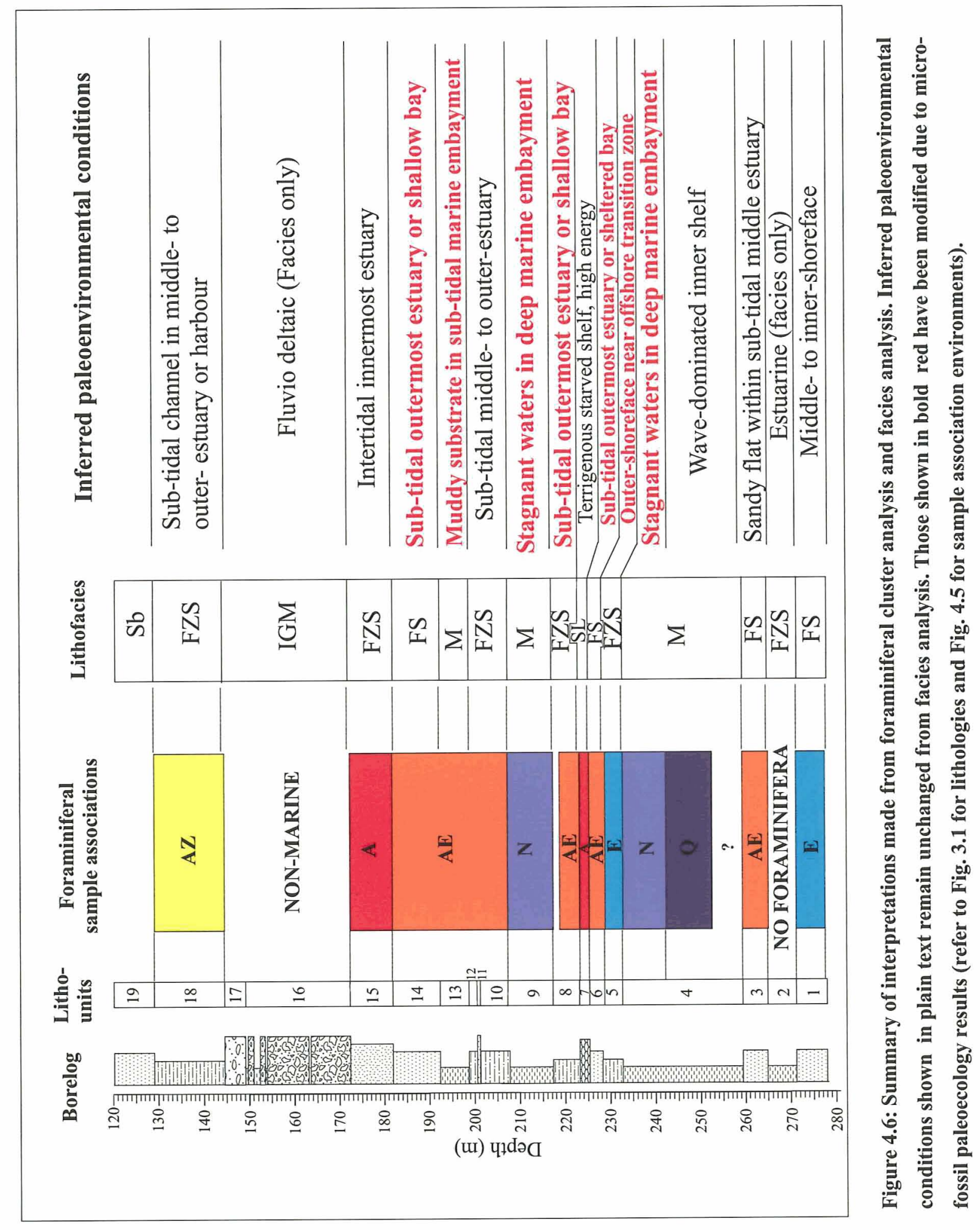




\section{CHAPTER 5 \\ CYCLOSTRATIGRAPHY}

\subsection{INTRODUCTION}

This chapter analyses the vertical stacking patterns of lithofacies developed in chapters 3 and 4 and asses their relationship to changes in relative sea level. A cycle is defined here as a succession of genetically related lithofacies that were deposited during the complete course of a recurring process (i.e. Boggs, 1995). However, cycles can only be identified from the marine strata comprising the lower $180 \mathrm{~m}$ of the borehole (litho-units 1-21) as the strata in the upper $100 \mathrm{~m}$ of the borehole (litho-units 22-36) are terrestrial in origin and cannot be described using cyclostratigraphy.

\subsubsection{Non-cyclostratigraphic units in the borehole}

Strata between 100-40m depth are composed thin (3-4m) beach and dune sand deposits (Facies $\mathbf{S b}$ and $\mathbf{S d}$ ) and floodplain silt deposits (Facies $\mathbf{Z}$ ), which are interbedded with thick (5-10m) fluvial gravel units (Facies G) (Fig. 5.1). Associations of the facies are interpreted as representing a siliciclastic strandplain succession (e.g. Thom, 1983) (Fig. 5.1). Strandplains commonly develop during late sea level highstand periods or regressions upon coastlines that are characterised by high rates of sediment supply. For example, on the SE coast of Brazil, a strandplain developed following the Last Interglacial transgression in response to a large sediment supply and gradual westward movement of the coastal depocentre, which now forms an uplifted marine terrace (Dominguez et al., 1987).

The top 40m of the borehole consists of fluvial gravel deposits (Facies G) that are interbedded with thin (2-3m thick) overbank floodplain silt deposits (Facies $\mathbb{Z}$ ). This facies association resembles a coarse-grained floodplain succession (e.g. Miall, 1978; Miall, 1992) (Fig. 4.1). The gravel beds are interpreted to represent former aggradation surfaces deposited from rivers, which intensely debouched large masses of gravel upon the coastal plain. Phases of aggradation were then followed by periods of lower flow 
and back swamp, fine grained vertical accretion that deposited the silt beds ( $c f$. braid channel accretion of Rust (1972).

\subsection{MODERN CYCLOSTRATIGRAPHY}

Modern cyclostratigraphy has been advanced in recent time with the development of sequence stratigraphy, which provides a means of predicting successions of facies deposited during particular phases of a relative sea level cycle, usually within a chronostratigraphic framework (Van Wagoner et al., 1988; Posamentier and Vail, 1988). This is achieved by grouping strata that are genetically related into relatively conformable successions, which are believed to have been deposited during specific stages of a relative sea level cycle (Posamentier and Vail, 1988). The basic building block of a stratigraphic sequence is the system tract, which is a linkage of contemporaneous depositional systems (Van Wagoner, 1995). Each system tract is bounded by discontinuity surfaces, such as unconformities or their correlative conformities, and by lithofacies associations and successions (Posamentier and Vail, 1988). There are four main types, which equate to states of relative sea level change: 1) Transgressive systems tracts (TST), which comprise packages of sediment (usually marine) deposited during relative sea level rise; 2) Highstand systems tracts (HST), which comprises sediment from the coastal shelf deposited landward over existing nearshore strata as sea level reaches a highstand position; 3) Regressive systems tract (RST), which comprises sediment deposited during relative sea level fall; and, 4) Lowstand systems tract (LST), which comprises sediment deposited during a relative sea level lowstand.

\subsection{THE ARCHETYPAL CYCLE}

An archetypal cycle, which summarises an ideal succession of lithofacies for one complete sea level cycle (transgression to transgression), is shown in Figure 5.2. 

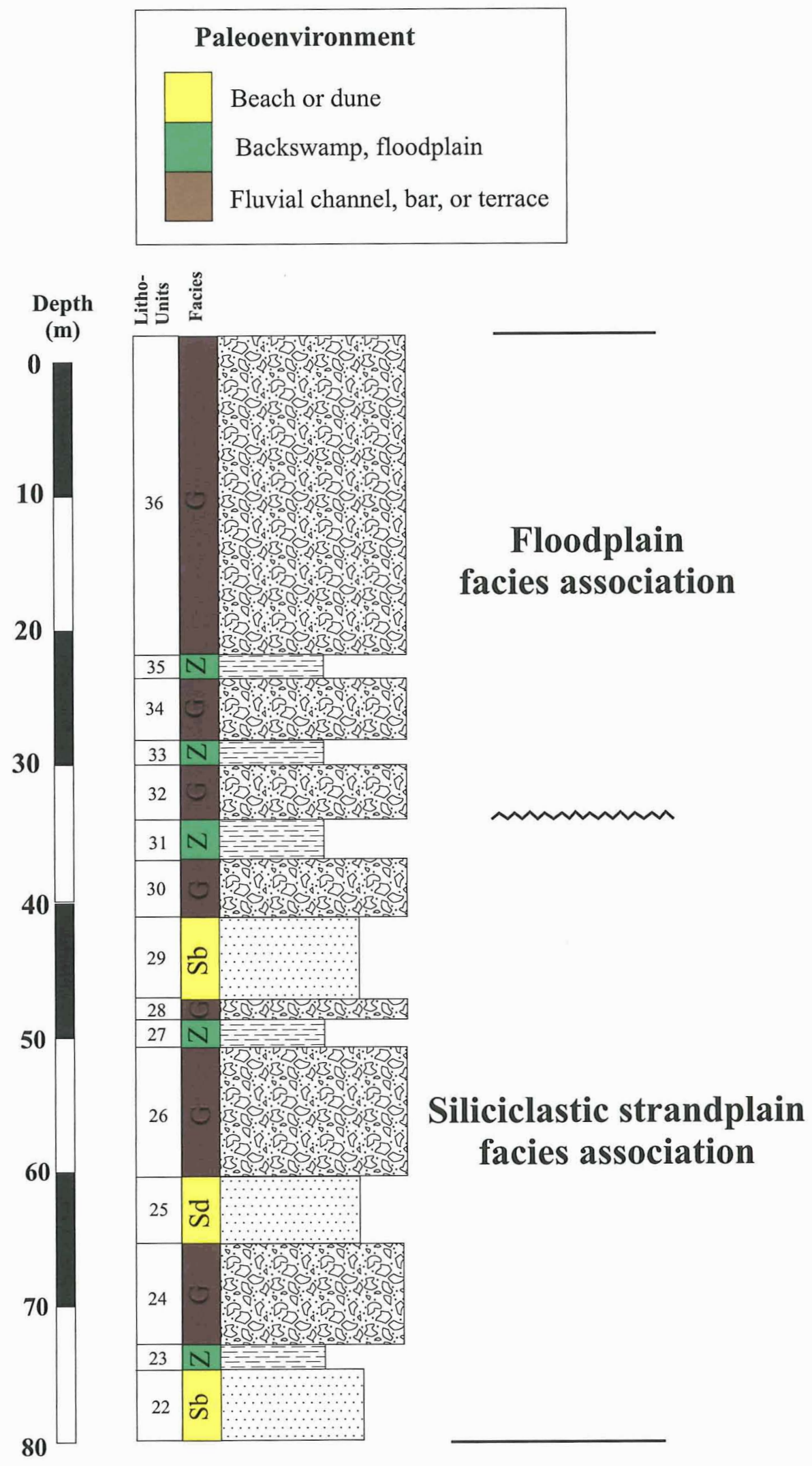

Figure 5.1: Facies relationships in the top $80 \mathrm{~m}$ of borehole strata.

Between $\mathbf{8 0 - 3 5 m}$ is a siliciclastic strandplain association whereas

the top c. $35 \mathrm{~m}$ is a floodplain association. (Refer to Fig. $\mathbf{5 . 2}$ for lithology). 
The cycle has been constructed from previous studies of facies and sea level change (e.g. Walker and James; 1992; Boggs, 1995; Coe et al., 2003), and also incorporates definitions of systems tracts and discontinuity surfaces developed from studies of cyclical shallow marine sediment in Wanganui Basin (e.g. Carter et al., 1991; Abbott and Carter, 1994; Naish and Kamp, 1997a; Mitchell, 2001). However, it must be noted that it is rare to observe a complete cycle in the geologic record. But where the models relationships are observed it can be used as a base model for predicting facies response to particular phases of a relative sea level cycle.

\subsubsection{Cycle Boundary (CB)}

In general, cycle boundaries correspond with ravinement surfaces (RS), which are the product of landward migration of an erosional shoreface (Demarest and Kraft, 1987) (Fig. 5.2). This is because cycle boundaries often truncate lowstand systems tracts and will lie superimposed over a lowstand sub-aerial unconformity (Fig. 5.1) (Mitchell, 2001). Seaward of wave base, the cycle boundaries correlative conformity is the transgressive surface (TS), which marks the boundary of the LST and TST (Posamentier and Vail, 1988) (Fig. 5.2).

\subsubsection{Transgressive Systems Tract (TST)}

Transgressive systems tracts are bounded below by either a RS or TS, which will truncate the top of the underlying sequence and will compose the $\mathrm{CB}$. The top of the TST is bounded by the down-lap surface, which separates transgressive strata from those deposited during relative sea level highstand (see section 5.3.3).

TST deposits generally comprise fining-, deepening-upward facies successions that develop from landward shifting of environments in response to relative sea level rise (e.g. Boggs, 1995; Abbott, 1998; Mitchell, 2001) (Fig. 5.2). The deposits are usually rich in detrital shell fragments and reworked neritic micro-fauna that indicate rapid deepening (based on microfossil paleobathymetry) (Naish and Kamp, 1997b; Leckie and Olson, 2003). 

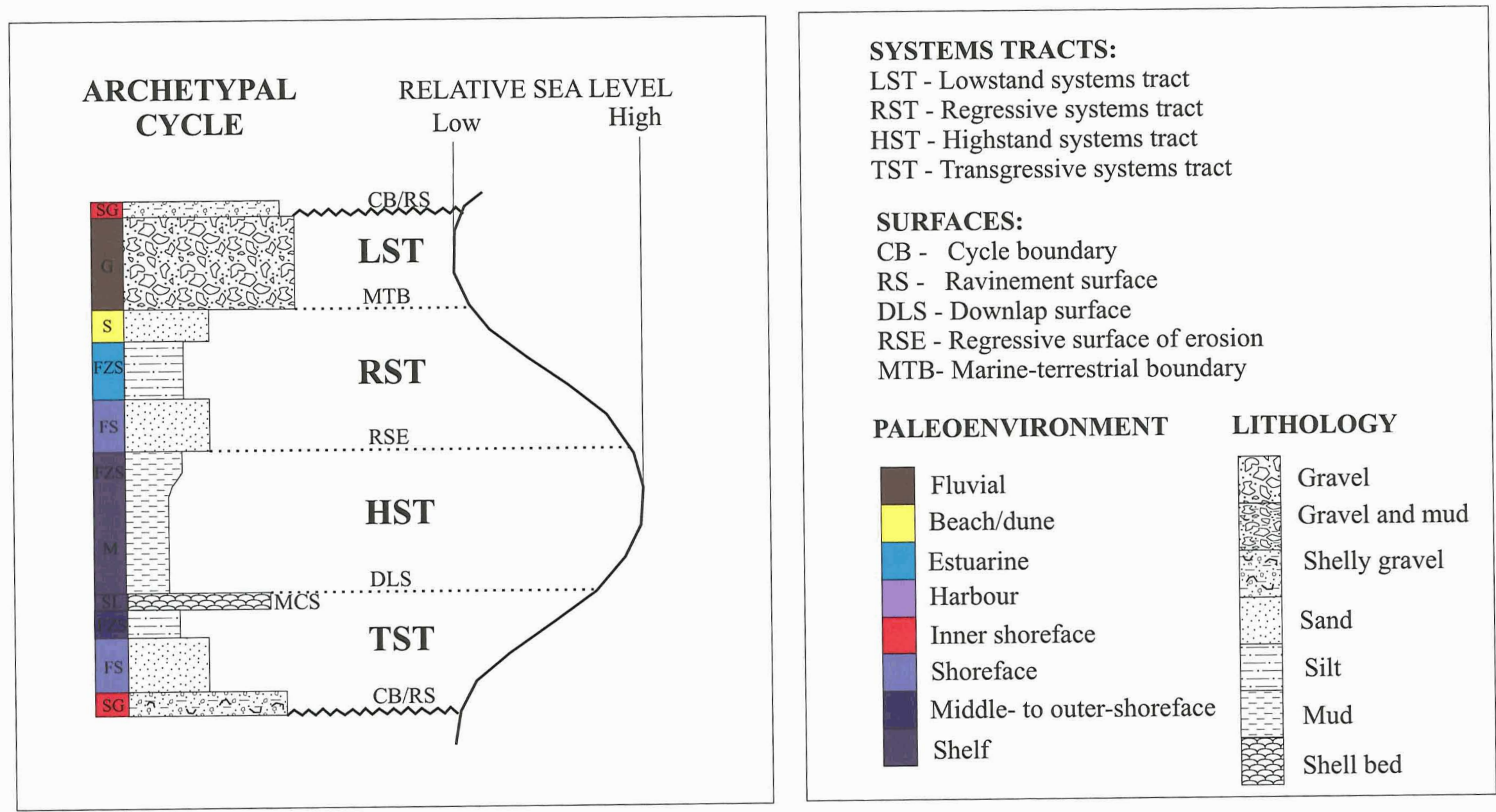

Figure 5.2: Archetypal cycle that predicts the depositional sequence of lithofacies deposited during one symmetrical eustatic cycle, assuming a constant and linear sedimentation rate through time (after Mitchell, 2001) (see text). 
In estuarine environments, the TST will comprise estuarine deposits that will occupy incised valleys, which were cut during a previous lowstand periods (e.g. Dalrymple, 1992; Hori et al., 2001; Yoo et al., 2002). On linear coastlines, transgression will form barriers and estuaries that will produce a facies succession consisting of estuarine sediment followed by shoreface sand deposits, then eventually outer-shoreface silty sand and shelf mud deposits as sea level continues to rise (Demarest and Kraft, 1987; Boyd et al., 1992). However, the deepening part of this succession is not commonly preserved as it is ephemeral, being eroded as the erosional shoreface advances landward (Coe et al., 2003). Instead the TST will be replaced by a thin shell-rich layer (e.g. Naish and Kamp, 1997a), and inner shelf mud deposits will lie superimposed on top of this (Demarest and Kraft, 1987).

\subsubsection{Down-lap Surface (DLS)}

The down-lap surface marks the change from retrogradational sedimentation (e.g. TST) to progradational sedimentation that is caused by seaward migration of the shoreface sediment wedge during relative sea level highstand (Coe et al., 2003) (Fig. 5.2). The DLS usually corresponds with the top of a shell bed that contains an in situ shelf faunal assemblage. Examples of these are Type B shell bed of Abbott and Carter (1994), Midcycle condensed shell bed of Abbott (1997), or back-lap shell bed of Naish and Kamp (1997a) from the Wanganui Basin. According to Vail et al. (1984) these shell beds develop seaward of an erosional shoreface on the inner shelf as a result of terrigenous sediment starvation associated with the landward movement of the coastal depocentre during transgression. Consequently they correspond to the maximum flooding surface, which marks the boundary between transgressive and highstand systems tracts (e.g. Abbott, 1997) (Fig. 5.2).

\subsubsection{Highstand Systems Tract (HST)}

Highstand systems tracts group all sediments deposited during from when sea level reaches a highstand to when it begins to fall (Posamentier and Vail, 1988). In the case of glacio-eustatic cycles, this will occur during interglacial periods. They are bounded below by the down-lap surface and above by the regressive surface of erosion, which 


\subsubsection{Lowstand Systems Tract (LST)}

Lowstand systems tract refers to sediments deposited during relative sea level lowstand. In the case of glacio-eustatic cycles this will occur during glacial periods. Above the shoreline, lowstand systems tracts will consist of widespread fluvial deposition and floodplain development that produces coarse-grained alluvium and fine-grained silt deposits (Posamentier and Vail, 1988) (Fig. 5.2). However, some sequence stratigraphic models predict that incision will occur during lowstand periods due 10 stream rejuvenation (e.g. Blum and Price, 1998). Contrary to this, recent studies of siliciclastic margins have shown that rivers do not necessarily incise during lowstands if they flow out onto a coastal plain flanked by a broad low gradient shelf (Miall, 1991; Leckie, 1994; Browne and Naish, 2003). This is because the newly exposed shelf gradient will be less steep than the sub-aerial alluvial plain. For example, according to Browne and Naish (2003) fluvial incision did not occur on the Canterbury Plains during the sea level fall that preceded the Last Glacial Maximum (c.20ka). Instead, sub-aerial accommodation space was created resulting in widespread aggradation of a braidplain as it adjusted its grade in response to a 'forced regression' on a broad, low gradient shelf.

\subsection{CyCLOSTRATIGRAPHY IN THE LEVIN BOREHOLE}

Four sedimentary cycles have been recognised in the Levin borehole based on the criteria outlined above (Fig. 5.3). The cycles occur within predominantly marine lithounits 1-21 located between 263-100m depths and are believed to have formed from changes in relative sea level that caused transgression-regression of the coastline. Below $263 \mathrm{~m}$ depth the borehole sequence contains inner-shoreface sand deposits (litho-unit 1) that is overlaid by estuarine silty sand deposits (litho-unit 2), which are largely barren of fossils. They are interpreted as representing a RST of a preceding cycle that was not fully recorded in the borehole and therefore will not be pursued any further. 


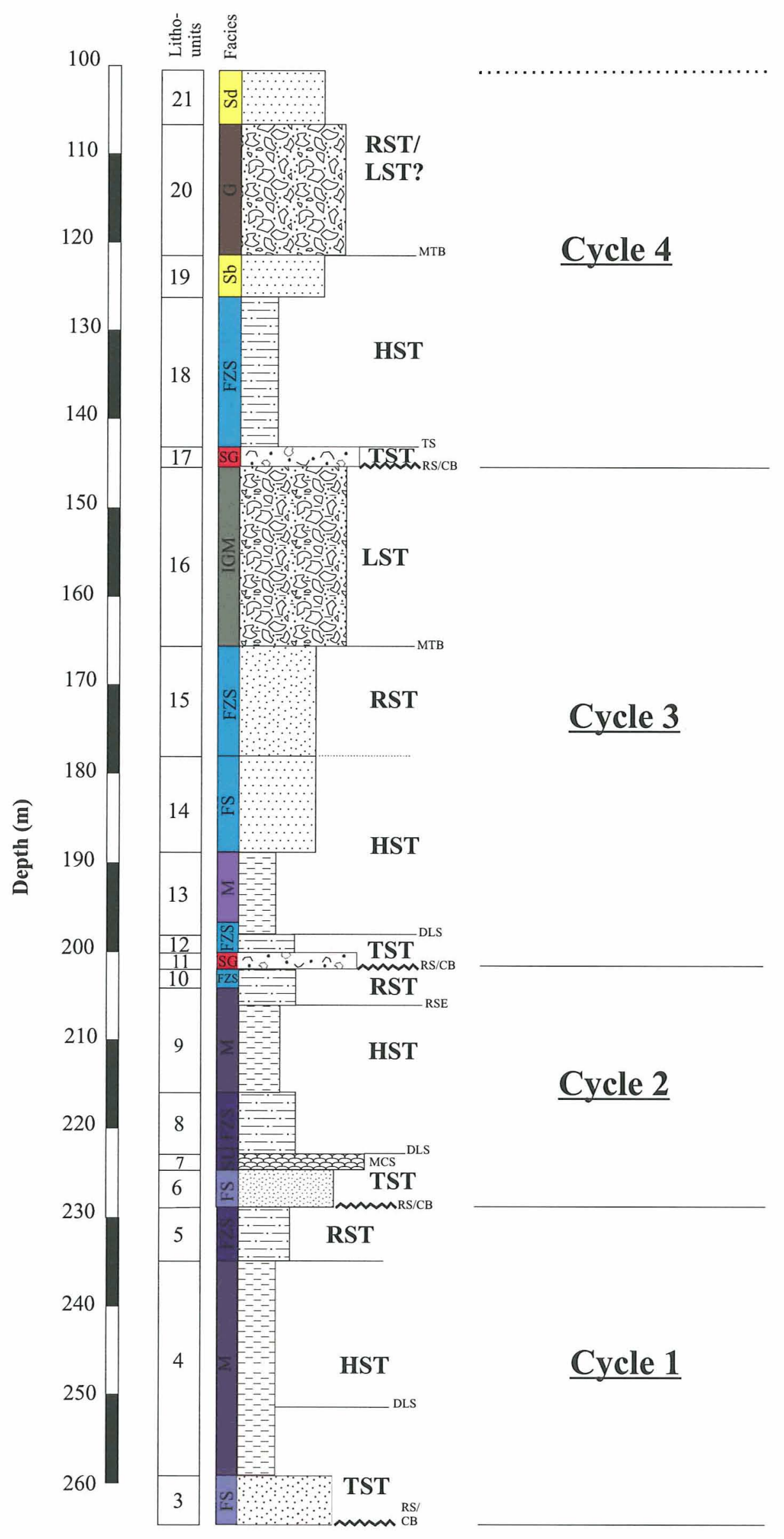

Figure 5.3: Architecture of sedimentary cycles in Levin borehole.

(Refer to Fig. 5.2 for definitions of systems tracts, surfaces, and keys.) 


\subsubsection{Cycle 1 (264-228m depth)}

Cycle 1 contains a $10 \mathrm{~m}$ thick TST that consists of shoreface sand deposits (litho-unit 3) and bioturbated inner shelf mud deposits (lower part of litho-unit 4). The TST represents a fining-upward succession and an abrupt increase in water depth over a wave-graded shelf-shoreface environment (e.g. Posamentier and Vail, 1988). The TST is overlain by shelfal mud deposits (upper part of litho-unit 4), which are assigned to the HST. A DLS is inferred to lay around $242-245 \mathrm{~m}$ depth where a change from a Quinqueloculina-dominated to Notorotalia-dominated foraminiferal assemblage occurs, which indicates maximum flooding of the shelf (e.g. Leckie and Olson, 2003). The DLS also coincides with an appearance of marine fauna in litho-unit 4 that contains an in situ assemblage of molluscs ( $c f$. Abbott, 1997). A thin RST consisting of outer-shoreface silty sand deposits (litho-unit 5) overlies the HST and the boundary between the two defines the RSE. There is no LST associated with this cycle; it was probably removed as a result of erosion during a later sea level rise (e.g. Coe et al., 2003).

\subsubsection{Cycle 2 (228-202m depth)}

The base of Cycle 2 truncates the top of Cycle 1 and represents a RS that also corresponds to the CB (Fig. 5.3). The TST of Cycle 2 is composed of inner-shoreface sand deposits (litho-unit 6) and a mid cycle shell bed, which contains an in situ shoreface-shelf faunal assemblage (litho-unit 7 and Facies SL) (cf. Abbott, 1997). A down-lap surface is inferred to lie above the mid cycle shell bed, which separates the TST and HST (Fig. 5.3). Overlying the DLS are outer-shoreface silty sand deposits (litho-unit 8) and inner shelf mud deposits (litho-unit 9), which are assigned to the HST. The top of the HST is interpreted to represent a RSE that separates inner shelf deposits from an overlying thin estuarine silty sand unit (litho-unit 10), which is ascribed to the RST. Similar to Cycle 1, there is no LST associated with this cycle as it may have been removed by erosion during a subsequent rise in sea level (e.g. Coe et al., 2003). 


\subsubsection{Cycle 3 (202-147m depth)}

Cycle 3 is bounded below by a ravinement surface, which truncates the top of Cycle 2 (Fig. 5.3). The TST and CB consists of thin shelly gravel lag (litho-unit 11) and estuarine silty sand deposits (litho-unit 12). The TST is overlain by marginal marine mud deposits (litho-unit 13) ascribed to the HST, which were deposited in a tidal marine embayment in $2-30 \mathrm{~m}$ of water as indicated from foraminiferal paleobathymetry. The HST is directly overlain by estuarine sand and inner-estuarine gravely silty sand deposits (litho-units 14 and 15), which are ascribed to the RST. No RSE has been recognised between the HST and RST as sedimentation between the two may represent a conformable sequence (e.g. Boggs, 1995; Naish and Kamp, 1997a) (Fig. 5.3). Cycle 3 also contains a LST composed of interbedded gravel and mud deposits (litho-unit 16), which represents prograding alluvial plain strata (Facies IGM). The contact between the RST and LST is termed the marine terrestrial boundary (MTB) (Fig. 5.3), and maybe a time-transgressive surface that formed as fluvial strata prograded directly over marginal-marine strata depositing gravel directly at the shoreline (e.g. Shepherd, 1987; Naish and Kamp, 1997a).

\subsubsection{Cycle 4 (147-100m depth)}

Cycle 4 is bounded below by a transgressive surface, which separates estuarine strata (litho-unit 17) from underlying fluvial gravels of Cycle 3 (litho-unit 16) (Fig. 5.3). Litho-unit 17 is ascribed to the TST and represents an incised valley fill succession that developed in river valleys cut during the previous lowstand period ( $c f$. Posamentier and Vail, 1988; Boggs, 1995). The TST is directly overlain by beach sand, fluvial gravel, and dune sand deposits (litho-units 19,20, and 21) that are assigned to the HST (e.g. Dalrymple, 1992) (Fig. 5.3). The HST and RST are considered synonymous in this cycle, both consisting of fluvial gravel and dune/beach sand deposits representing infilling of an estuarine embayment during relative sea level highstand and fall under a sediment supply dominant regime (e.g. Boggs, 1995; Naish and Kamp, 1997a) (Fig. 5.3). The LST of this cycle cannot be distinguished from the borehole; however it could be represented by non-marine strata in the top $80 \mathrm{~m}$ of the borehole. 


\subsection{ORIGIN OF SEDIMENTARY CYCLES}

A suggested origin of each cycle in the borehole can be inferred by comparing their architecture to unconformity bound allocyclic sedimentary packages found in the Wanganui Basin (e.g. Carter et al., 1991; Pillans, 1991; Naish and Kamp, 1997a; Abbott, 1998). Strata in this basin have been interpreted as being deposited during late sea level rise, highstand and early fall parts of a glacioeustatic cycle represented by interglacial periods (e.g. OIS 5, 7, 9, 11 etc.) (Beu and Edwards, 1984; Carter and Naish, 1998). By contrast, glacial stages (e.g. OIS 2, 4, 6, 8 etc.) are represented by surfaces of marine planation that occur at the base of each cycle (Carter and Naish, 1998). In total, 47 superimposed cycles are recognised that have been grouped into seven major cyclothemic sequences, which reflect glacioeustatic fluctuations over the paleo-New Zealand shelf (Carter and Naish, 1998; Saul et al., 1999) (Fig. 5.4).

The architecture of Cycle 1 and Cycle 2 is similar to Castlecliff Cyclothems in Wanganui Basin (Carter and Naish, 1998), and in particular sequences labelled 7-10 by Carter et al. (1991), which have a periodicity of c.100ka (Fig. 5.4). Castlecliff Cyclothems are generally between $5-25 \mathrm{~m}$ thick and contain a thin TST consisting of well sorted sands and mid cycle shell bed, a HST of shelfal massive or bedded siltstone, a thin or absent RST, and no LST that was truncated by the overlying sequence (Abbott, 1997; Carter and Naish, 1998). Maximum HST depth is usually between c.25-75m based on foraminiferal paleobathymetry (Abbott, 1998; Saul et al., 1999) (Fig. 6.3). The Castlecliff Cyclothem is interpreted to be the result of $5^{\text {th }}$ order (c.100ka) glacioeustatic fluctuations over middle- to inner-shelf (Carter and Naish, 1998). Cycles 1 and 2 are inferred to have a similar origin to the Castlecliff Cyclothem (Fig. 5.4).

The architecture of Cycle 3 and Cycle 4 is similar to cyclical strata that comprises uplifted marine terraces in Wanganui Region, which span oxygen isotope stages 17-3 (Pillans, 1983; Pillans, 1994) (Fig. 5.4). According to Pillans (1994), these terrace deposits are generally between 10-20m thick and consist of a thin TST of shelly conglomerate, shallow marine HST (maximum water depth of c.5-10m), shoreface RST, and non-marine LST. The terraces have been termed Haweran Cyclothems by Saul et al. (1999) and are believed to be the result of $5^{\text {th }}$ order (c.100ka) glacioeustatic 
sea level fluctuations over a smoothly uplifting shoreline. A similar origin is postulated for cycles 3 and 4 in the Levin borehole (Fig. 5.4).

\subsection{SUMMARY OF CYCLOSTRATIGRAPHY}

In summary, four marine sedimentary cycles have been recognised in the lower part of the Levin borehole between 264-100m depths (litho-units 3-21). These are interpreted using cyclostratigraphy and are shown to reflect changes in relative sea level. Upon comparing these to well constrained Plio-Pleistocene marine successions in the Wanganui Basin, for which the sea level record is known from oceanic oxygen isotope records, an origin has been suggested. Cycles 1 and 2 correlate well with Castlecliff cyclothems, which formed from $5^{\text {th }}$ order (c.100ka) glacioeustatic sea level fluctuations on an inner shelf, whereas Cycle 3 and 4 correlate with Haweran Cyclothems, which formed from similar periodical sea level fluctuations on a shoreface environment. By contrast, the upper $100 \mathrm{~m}$ of the borehole is predominantly non-marine and cannot be described using cyclostratigraphy. Strata between 120-40m depths are interpreted to represent a siliciclastic strandplain succession and the upper $40 \mathrm{~m}$ of the borehole represent a floodplain succession. 


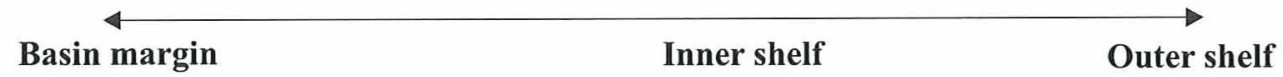

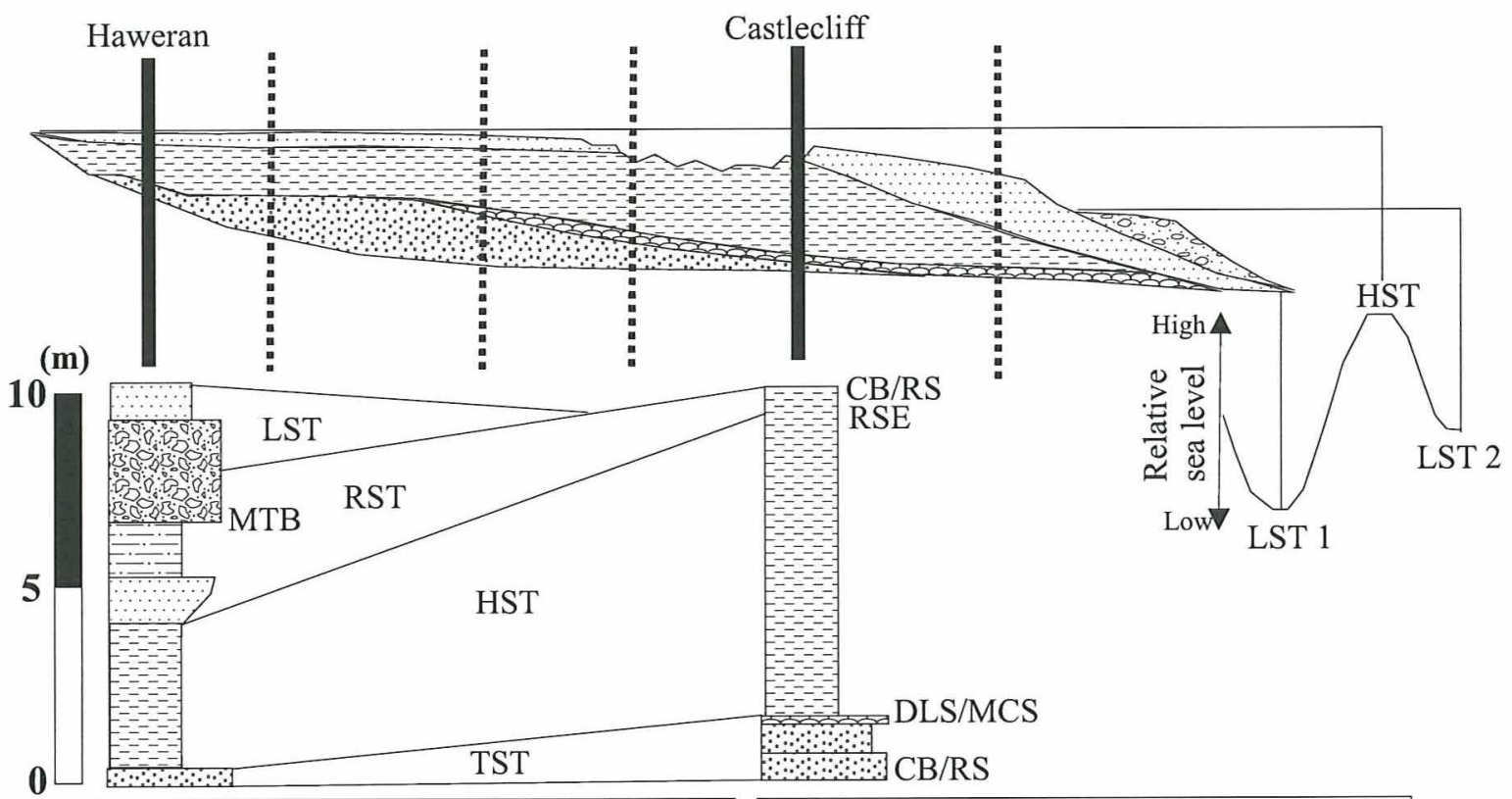

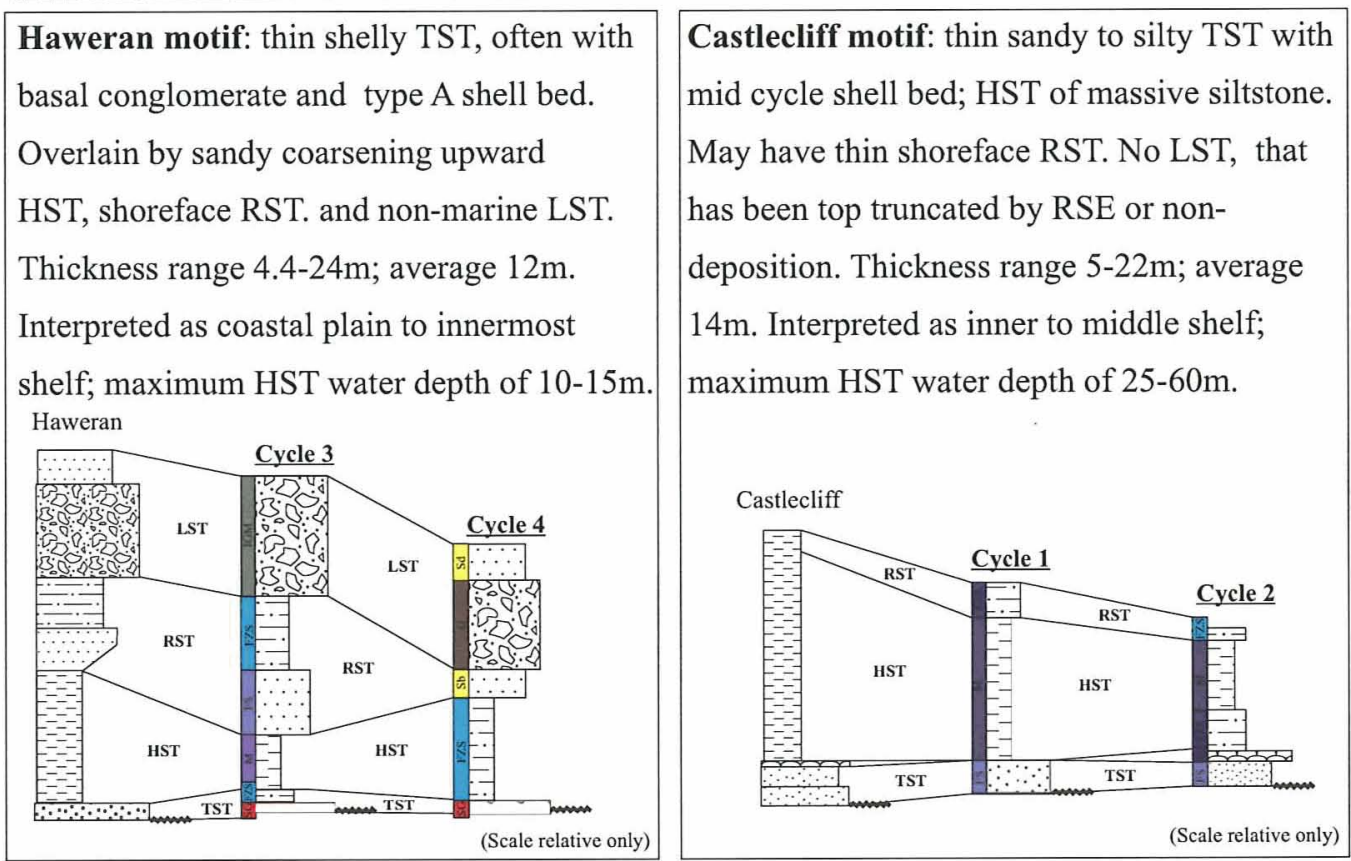

Figure 5.4: Summary stratigraphic model for the Wanganui Basin showing location and architecture of Castlecliff and Haweran motifs (after Saul et al., 1999) (refer to key in Fig. 5.2). Also shown are sedimentary cycles from this study and their suggested origin. Cycles 1 and 2 correlate well with Castlecliff cyclothems and Cycles 3 and 4 correlate well with Haweran Cyclothems. 


\section{CHAPTER 6 \\ PALYNOLOGY}

\subsection{INTRODUCTION}

The main goals of this palynological study were to: 1) reconstruct the history of past vegetation in the Horowhenua District; 2) relate vegetation change to past environmental conditions; and, 3) help create a stratigraphic-chronologic framework for the Levin borehole by assigning strata to interglacial-glacial climate periods.

\subsubsection{Sample selection and palynomorph identification}

Samples from the borehole that contained over $80 \%$ sand and silt particles were selected for pollen and spore analysis as palynomorphs were most likely to be present in this size fraction. They were processed using the methods outlined by Moore and Webb (1989), which is outlined in App. E. Palynomorphs were counted and identified using a Leitz compound microscope. Slides were traversed horizontally under 400X magnification and all pollen which fell into the field of view was recorded on a score sheet. The slide was moved $1 \mathrm{~mm}$ vertically between each traverse. Counting continued until the whole slide was traversed or a statistically viable number was reached, usually between 300400 grains (Birks and Birks, 1980). In some cases a second slide was counted if the first yielded a count of less than 400 grains and the final counts were combined. Palynomorphs were identified by comparing them to modern pollen and spores contained within the Victoria University School of Earth Sciences reference slide collection as well as publications (Large and Braggins, 1991; Moar, 1993). In some cases, poor preservation and excess organic matter on slides obscured pollen grains and made identification difficult; however, this applied to a minority (10\%) of samples.

\subsection{Palynology Results}

Forty one slides from 28 samples between $24-263 \mathrm{~m}$ depth were analysed for pollen and spores (App. E). Of the samples analysed, 21 contained palynomorphs and 7 were barren. In total, 47 pollen and spore species were identified (Table 6.1; Fig. 6.1). Counts 
per slide ranged from 454 to 121 , which were computed to relative abundances for interpretative purposes and any ambiguities between total counts are assessed.

Table 6.1: List of pollen and spores encountered within the Levin borehole.

\begin{tabular}{|c|c|c|c|}
\hline $\begin{array}{l}\text { BEECH } \\
\text { Fuscospora-type } \\
\text { Nothofagus menziesii } \\
\text { PODOCARPS, } \\
\text { BROAD LEAVED TREES, } \\
\text { AND TREE FERNS } \\
\text { Dacrydium cupressinum } \\
\text { Dacrycarpus dacrydioides } \\
\text { Prumnopitys ferruginea* } \\
\text { Prumnopitys taxifolia } \\
\text { Prumnopitys acutifolius } \\
\text { Podocarpus totara } \\
\text { Podocarpus sp. } \\
\text { Metrosideros } \\
\text { Weinmania } \\
\text { Dactylanthus* } \\
\text { Cyathea-type } \\
\text { Dicksonia-type }\end{array}$ & $\begin{array}{l}\text { SMALLTREES } \\
\text { AND SHRUBS } \\
\text { Halocarpus } \\
\text { Phyllocladus } \\
\text { Arsitotelia } \\
\text { S, Ascarina lucida } \\
\text { Griselinia } \\
\text { Hoheria* } \\
\text { Pittosporum } \\
\text { Pseudopanax } \\
\text { Pseudowintera* } \\
\text { Melicytus* } \\
\text { Carpodetus* } \\
\text { Fuchisia* } \\
\text { Leptospermum } \\
\text { Asteraceae } \\
\text { Coprosma } \\
\text { Dracophyllum* } \\
\text { Epacridaceae }\end{array}$ & $\begin{array}{l}\text { Hebe* } \\
\text { Pimelea* } \\
\text { Gaultheria-type* } \\
\text { Forstera* } \\
\text { Apiaceae } \\
\text { Astelia } \\
\text { Brassicaceae } \\
\text { Poaceae } \\
\text { Plantago-type* } \\
\text { Gahnia-type* } \\
\text { WETLAND }\end{array}$ & $\begin{array}{l}\text { FERNS AND } \\
\text { FERN ALLIES } \\
\text { Lycopodium-type* } \\
\text { Monolete ferns }\end{array}$ \\
\hline
\end{tabular}

\subsubsection{Pollen and spore representation}

Pollen and spores can be sourced from a variety of local, extra-local, or regional vegetation sources, and the type of record preserved will depend on transportation process (either wind or water), depositional environment, and morphology of individual grains (Moore et al., 1991; Holmes, 1994). Local pollen signals accumulate in proximal areas such as peat bogs, lakes, and rivers and are mostly deposited via atmospheric rain. As a result, wind pollinated taxa that produce large amounts of pollen maybe overrepresented these signals such as Dacrydium cupressinum, Fuscospora-type, Coprosma, and Cyathea-type (Moar, 1971; Pocknall, 1978). Alternatively, some taxa have been noted to be transported large distance with prevailing winds and be found out of their local source area. For example, small forests of Nothofagus even have the power to dominate local pollen rain as what was discovered by Moar (1970) who found that Fuscospora from lowland beech forests dominated the pollen spectra in upland subalpine scrubland-grasslands. Soils, which form in peat bogs, can rapidly degrade pollen though biological activity leaving a typical residue of corrosion resistant palynomorphs such as tree-fern spores (Bryant et al., 1994; McGlone, 2001). 


\section{Caption for Figure 6.1:}

1: Nothofagus menziesii (x400). 2: Nothofagus fusca type (Fuscospora type) (x250). 3: Dacrydium cupressinum (x250). 4: Dacrycarpus dacrydioides (x200). 5: Podocarpus totara (x150). 6: Prumnopitys taxifolia (x100). 7: Metrosideros (x500). 8: Dactylanthus taylori (x400). 9: Weinmania racemosa (x500). 10: Halocarpus (x200). 11: Phyllocladus (x250). 12: Aristotelia (x700). 13: Ascarina lucida (x500). 14: Griselinia (x500). 15: Pittosporum type (x500). 16: Pseudopanax type (x350). 17: Leptospermum (x500). 18: Coprosma (x250). 19: Dracophyllum type (Epacridaceae) (x500). 20: Fushia (x400). 21: Apiaceae (x500). 22: Asteraceae (x175). 23: Astelia (x500). 24: Phormium (x200). 25: Chenopodium (x500). 26: Dicksonia type (x250). 27: Cyathea type (x250). 28: Monolete fern spore (x250) 


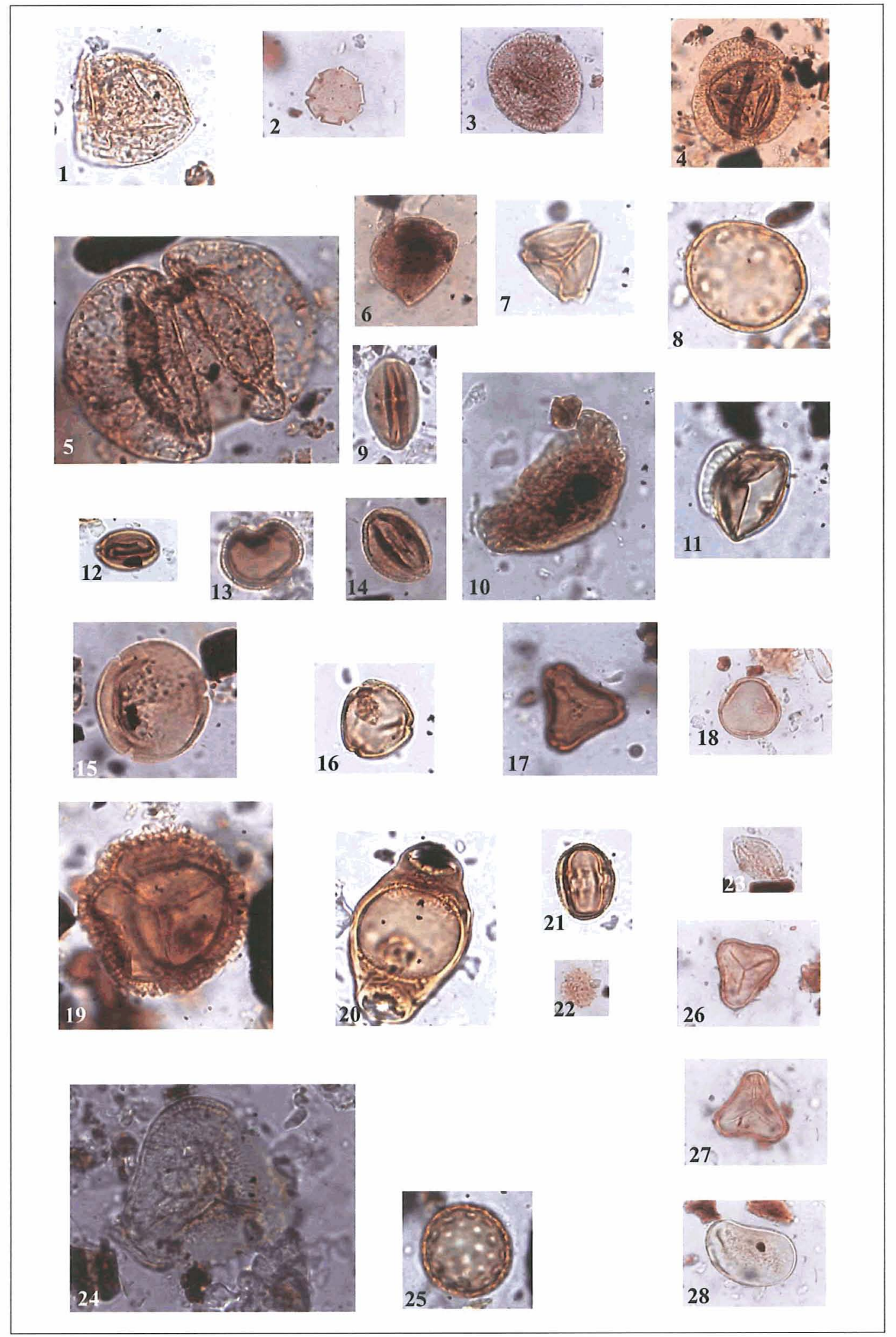

Figure 6.1: Photographs of the more common and characterising pollen and spores found in the Levin borehole. 
Subsequently, these may get reworked into fluvial and lacustrine deposits causing them to become over-represented, which has the potential to obscure the relationship between pollen and spore assemblages and the contemporary vegetation cover (e.g. Pillans et al., 1988). By contrast, lakes and rivers source both wind and water pollinated taxa, and sometimes have a higher representation of non-wind dispersed pollen types such as Metrosideros, Nestigis, and Quintinia (Macphail and McQueen, 1983; McGlone, 2002).

Extra-local and regional pollen signals accumulate in shallow marine and deep sea depositional environments respectively (e.g. Heusser and van de Geer, 1994; Dunbar et al., 1997; Wilmshurst et al., 1999; McGlone, 2001; McGlone, 2002; Armour, 2003). In shallow marine situations, pollen and spores are sourced from either wind or water. Tidal currents in these environments may homogenise pollen and spores and the resulting record will broadly reflect landscape vegetation (Armour, 2003). In settings with a large fluvial sediment supply, the pollen assemblage may become characterised by large amounts robust grains, for example Cyathea-type and Dicksonia-type fern spores, as these usually survive the transportation process (Dunbar et al., 1997; Wilmshurst et al., 1999). Consequently, their over-representation may obscure the true relationship between pollen and spore assemblages and the contemporary vegetation cover of the catchment. For example Wilmshurst et al. (1999) showed that tree fern spores were 2-6 times over-represented in a nearshore marine core relative to a mainland site in Poverty Bay. The same problem can also occur in deep marine environments. McGlone (2001) found tree fern spore percentages to be 2.5 times higher in a deep marine core offshore from Poverty Bay then in terrestrial sediment of the same age.

In offshore marine settings, pollen and spores are deposited following a two-stage transport path. Firstly they are transported either by wind or water to the ocean. Secondly, once in the surface waters of the ocean, pollen and spores are incorporated into larger organic complexes of faecal pellets and flocculated/agglomerated particles (Pickrill, 1987), which settle towards the bottom of the ocean. At the same time, coastal currents and surface waters move them along the coast and offshore (McGlone, 2001). Consequently, the settling process selects certain sizes and shapes of pollen grains. For example, an increase in the percentage of less-dense bissacate pollen from podocarps 
with increase distance offshore has been noted (Holmes, 1994; Heusser, 1988). A third source of palynomorphs commonly encountered in marine sediments is reworked grains from older deposits. For example, Wilmshurst et al. (1999) noted in their Poverty Bay terrestrial-marine comparison that Fuscospora was nearly three times as abundant in the marine core. They suggested that reworking from older Pleistocene or Tertiary limestone deposits accounted for this, which had the potential to obscure the relationship between pollen and spore assemblages and the contemporary vegetation.

\subsubsection{Preservation of palynomorphs}

The condition of pollen and spores extracted from the Levin borehole varied from excellent to poor. Some of the palynomorphs showing evidence of physical abrasion indicated high energy transportation and depositional environments (Moore et al., 1991). Those largely affected were fern spores (Cyathea-type, Dicksonia-type, and monolete fern spores), bissacate pollen from podocarps (mainly Prumnopitys taxifolia, Podocarpus totara, and Dacrycarpus dacrydioides), and Fuscospora-type. Fern spores were either broken along the laesura or deformed suggesting fluvial transportation prior to deposition (e.g. Moore et al., 1991; Dunbar et al., 1997). By contrast, some fern spores encountered had perispore still attached indicating lack of transport. Fragile bissacate pollen grains were commonly found with one or two sacci detached and were not identifiable beyond family level. Some grains encountered resembling Fuscosporatype was extremely corroded and deformed indicating long transport distances and possible reworking (e.g. Wilmshurst et al., 1999; McGlone, 2001). For this reason they were not included in the final count.

\subsection{Pollen zonation}

Palynology results are displayed using percentage frequency bar diagrams that were computed using the Psimpoll computer programme (Bennett, 1998) (Fig. 6.2). A pollen sum diagram was computed that summarised relative proportions of: beech; broad leaved forest, podocarps and tree ferns Cyathea-type and Dicksonia-type (as these are associated with broad leaved forests); small trees; herbs; wetland; and, fern and fern allies' taxa for each unit (Tables 6.1 and 6.2). Using the pollen sum, 10 pollen zones 
were prescribed where distinct changes in pollen and spore assemblages occur (Table 6.2; Fig. 6.2).

\subsubsection{Problems with using relative abundances}

Reconstructions of past vegetation were based on relative abundances of pollen and spore taxa. However, after converting absolute counts to relative abundances, problems can occur as pollen taxa become expressed as a percentage of a given sum (Moore and Webb, 1978). For example, large increases in one pollen species may be compensated by a corresponding decrease in other species creating confusion over what component of the pollen assemblage is varying. According to Moore et al. (1991), this problem can become particularly severe if certain taxa with a high pollen input undergo large fluctuations within the pollen diagram.

During this study, it became apparent that fern spores are over-represented within some samples. They are particularly abundant within samples derived from floodplain material reaching up to $80 \%$ mean relative abundance, which may have resulted from selective sorting of these during transportation and deposition (e.g. Dunbar et al., 1997; McGlone, 2001). Consequently, pollen from arboreal vegetation is under-represented in these samples, which affects subsequent vegetation reconstructions. One way to overcome this problem is to remove such over-represented palynomorphs from the pollen sum (Moore and Webb, 1978). Therefore a second pollen sum was produced where fern spores had been omitted to investigate the affect of their over-representation (Fig. 6.3). The figure shows upon removing fern spores, relative abundances of beech, small trees, herbs, and wetland taxa all increase although their relative proportions remain the same. This is because fern spore numbers did not undergo large fluctuations between many samples. In contrast, the sum of broad leaved trees either decreases or remains unchanged as high numbers of tree fern spores in these samples was increasing the total sum of broad leaved tree taxa, bearing in mind they have been included within the same sum, causing them to become over-represented. However, this only occurred in three samples from $36.3-37.2 \mathrm{~m}, 30.5-31.0 \mathrm{~m}$, and $24.8-25.3 \mathrm{~m}$ depths meaning overrepresentation of fern spores mostly did not affect relative proportions of tree taxa in the pollen sum. Therefore, for the purpose of this study, which is to relate vegetation to 
glacial/interglacial cycles, the following pollen zones have been described from the full taxonomic assemblage.

Table 6.2: Summary of relative proportions of: beech; broad leaved trees, podocarps, and tree ferns; small trees and shrubs; herbs; wetland; and, fern and fern allies' for borehole pollen zones.

\begin{tabular}{|c|c|c|c|c|c|c|c|c|c|c|}
\hline SLIDE \# & 02 & 03 & $\left|\begin{array}{llll}04 & 05 & 06 & 08\end{array}\right|$ & 1011 & $15 \quad 16$ & 27 & & 192021 & 22 & 2324252627 \\
\hline $\begin{array}{l}\text { Zone depth } \\
\text { (m) }\end{array}$ & $\begin{array}{l}24 \\
26\end{array}$ & $\begin{array}{l}30- \\
32\end{array}$ & $35-75$ & $\begin{array}{l}131- \\
147\end{array}$ & $\begin{array}{l}170 \\
182\end{array}$ & $\begin{array}{l}190 \\
195\end{array}$ & & $\begin{array}{l}205- \\
223\end{array}$ & $\left|\begin{array}{l}225 \\
233\end{array}\right|$ & $238-263$ \\
\hline Beech \% & 4 & 0 & $\begin{array}{llll}1 & 1 & 11 & 8\end{array} \mid$ & $\begin{array}{ll}0 & 3\end{array}$ & 3215 & 28 & & 271220 & 2 & $\begin{array}{lllll}3 & 2 & 1 & 3 & 2\end{array}$ \\
\hline $\begin{array}{c}\text { Broad leaved } \\
\text { trees, podocarps, } \\
\& \text { tree ferns } \%\end{array}$ & 8 & 38 & 67695744 & 5679 & 4466 & 33. & 55 & 475638 & 83 & 6861756987 \\
\hline $\begin{array}{l}\text { Small trees } \\
\& \text { shrubs \% }\end{array}$ & 5 & 0 & $\begin{array}{llll}9 & 6 & 13 & 29\end{array}$ & 78 & 115 & 11 & 8 & 141516 & 6 & $\begin{array}{lllll}6 & 8 & 5 & 6 & 1\end{array}$ \\
\hline Herbs \% & 1 & 0 & $\begin{array}{llll}4 & 1 & 1 & 5\end{array}$ & $\begin{array}{ll}0 & 3\end{array}$ & 21 & 3 & 1 & $\begin{array}{lll}3 & 2 & 2\end{array}$ & 2 & $\begin{array}{lllll}2 & 3 & 1 & 2 & 2\end{array}$ \\
\hline Wetland \% & 0 & 0 & $\begin{array}{llll}1 & 0 & 0 & 1\end{array}$ & 12 & 0 & 0 & 1 & 210 & 1 & $\begin{array}{llllll}0 & 1 & 0 & 1 & 0\end{array}$ \\
\hline $\begin{array}{c}\text { Ferns \& } \\
\text { fern allies \% }\end{array}$ & 82 & 61 & 19221712 & 239 & 717 & 81 & 6 & 31512 & 20 & $1821 \quad 1917 \quad 11$ \\
\hline $\begin{array}{c}\text { POLLEN } \\
\text { ZONES }\end{array}$ & 10 & 9 & 8 & 7 & 6 & 5 & 4 & 3 & 2 & 1 \\
\hline
\end{tabular}

\subsubsection{Description of pollen zones}

\section{Zone 1: 263-233m depth}

The lower boundary of this zone coincides with the base of Lithologic Unit 3, which is composed of fine well sorted sand, below which the gravelly mud (Unit 2) was unable to yield pollen. Zone 1 is characterised by a dominance of Cyathea-type (39-50\% mean relative abundance), Dicksonia-type (12-17\%), and monolete fern spores (10-20\%). Tree pollen is also abundant, Metrosideros and Dacrydium cupressinum are most common (each 10\%), followed by Podocarpus sp. and Fuscospora-type (each 5\%). Dacrycarpus dacrydioides, Prumnopitys taxifolia, Podocarpus totara, and Nothofagus menziesii are also present but rare each (1-2\%). 


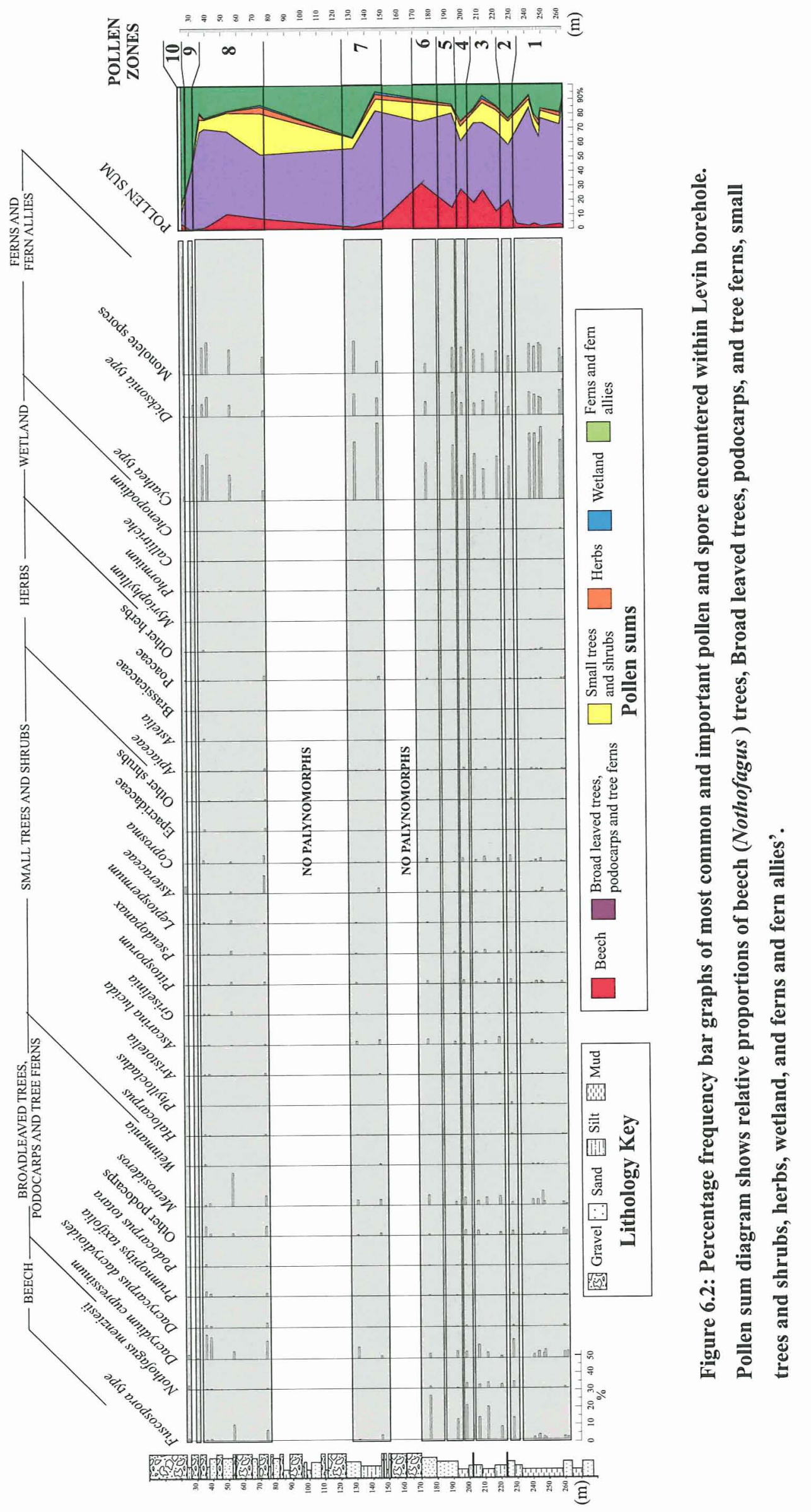




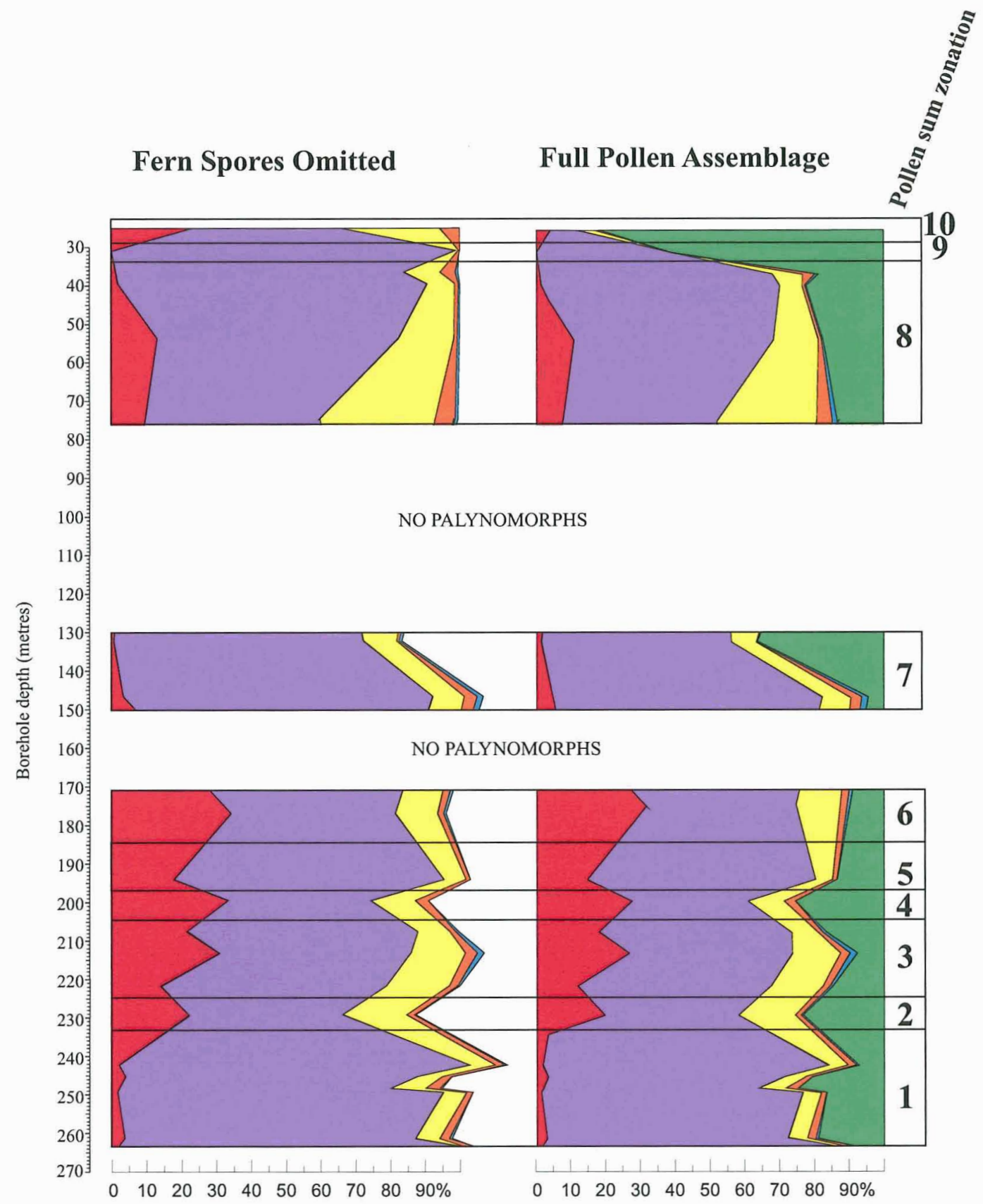

Figure 6.3: Comparison of pollen sum diagrams for a full pollen assemblage (right) and fern spores omitted (left). Diagram shows relative abundances of tree pollen types all increase when fern spores are removed; however, their relative proportions remain the same. (Refer to Fig. 6.2 for key). 
Pollen from small trees and shrub pollen is not common in Zone 1. Pittosporum, Pseudopanax, Ascarina lucida, Coprosma, and Asteraceae never reach above 3\% mean relative abundance, and Weinmania and Phyllocladus are present but rare $(<1 \%)$. Similarly, herb and wetland species such as Apiaceae, Poaceae, Astelia, Plantago-type, Gahnia-type, Chenopodium, Phormium, and Myriophyllum have only a sporadic occurrence $($ each $<1 \%)$.

\section{Zone 2: 233-225m depth}

The base of this zone is principally distinguished by an upward increase in Fuscosporatype and $N$. menziesii (up to 20\%) and D. cupressinum (13\%) and decrease in the abundances of Podocarpus sp., Metrosideros, P. taxifolia, P. totara, and D. dacrydioides (each 1-3\%) compared to Zone 1. Pollen from small trees and shrubs also increases upward in this zone, being dominated by Pittosporum, Pseudopanax, A. lucida and Coprosma (each 2-4\%). Other shrubs present include Phyllocladus, Aristotelia, Griselinia, Leptospermum, and Asteraceae (each 1-2\%). By contrast, herb and wetland taxa are not abundant; Apiaceae, Astelia, Poaceae, Myriophyllum, Chenopodium, and Callitriche that all comprise $<1 \%$ mean relative abundance.

\section{Zone 3: 225-205m depth}

An upward decrease in Fuscospora-type (9\%), N. menziesii (3\%), and D. cupressinum (2\%) and an increase in pollen from Metrosideros (5\%), Podocarpus sp. (5\%), and Ascarina (5\%) compared to Zone 2 defines the base of this zone. However, relative abundances of Fuscospora-type and D. cupressinum all increase again in the latter part of this zone at an expense of Metrosideros and Podocarpus sp. Cyathea-type (21-30\%), Dicksonia-type (10-15\%), and monolete fern spores (15\%) also appear over-represented in this zone. Pollen from small trees and shrubs Pittosporum, Pseudopanax, Asteraceae, and Coprosma are also present in this zone, but are not overly abundant (each 2-3\%). Similarly, Herb species Apiaceae, Astelia, and Brassicaceae are present but rare as are wetland species Myriophyllum, Phormium, Callitriche, and Chenopodium (each $<1 \%$ ). 
Zone 4: 205-196m depth

The base of Zone 4 is distinguished by an upward increase in Fuscospora-type (25\%) and $N$. menziesii (5\%), and a decrease in pollen from D. cupressinum, Metrosideros, $D$. dacrydioides, and Podocarpus sp. (each to 3-5\%) compared to Zone 3. Pollen from small trees and shrubs also increase upward in this zone, the main components being Pittosporum, Pseudopanax, Asteraceae, and Coprosma (each 2-3\%). However, herb and wetland taxa only occur sporadically, only Apiaceae makes a notable appearance at $2 \%$.

\section{Zone 5: 196-184m depth}

The basal boundary of Zone 5 is marked by an upward decrease in Fuscospora-type (to $14 \%$ ) and an almost complete disappearance of N. menziesii compared to Zone 4. This is accompanied by an increase in pollen from D. cupressinum (5\%), Metrosideros (3\%), and Cyathea-type fern spores (38\%). Relative proportions of pollen from small trees and shrubs also decrease upward in this zone, and only Pseudopanax and Ascarina make notable appearances (each 3\%). Likewise, pollen from herb and wetland taxa have a rare occurrence and only traces of Apiaceae and Poaceae were found (each $<1 \%$ ).

\section{Zone 6: $184-170 \mathrm{~m}$ depth}

Zone 6 is separated from Zone 5 by an upward increase in Fuscospora-type (to 31\%) and a reappearance of $N$. menziesii $(2 \%)$. D. cupressinum remains prevalent in this zone (4\%) as does Metrosideros (7\%). However, there is an upward increase in pollen from small trees and shrubs including Ascarina, Hoheria, Leptospermum, Pittosporum, Asteraceae, and Coprosma (each to 2-4\%). Herb taxa Apiaceae and Poaceae are also present but are rare (each $1 \%$ ).

\section{Zone 7: 147-131m depth}

Zone 7 is defined by large barren gaps in the pollen record above and below. The zone is characterised by large amounts of pollen conifers and broad leaved trees including $D$. cupressinum (8\%), Podocarpus sp. (3\%), Metrosideros (4\%), Cyathea-type (40-53\%), 
and Dicksonia-type (8-15\%). Other tree taxa present include P. taxifolia (2\%) and Weinmania (2\%). Notable is the absence of Fuscospora and N. menziesii in this zone. Pollen from small trees and shrubs are not as abundant in this zone compared to tree taxa. Those present include Ascarina, Griselinia, Pittosporum, Pseudopanax, and Asteraceae (each 2-4\%). In addition, herbs and wetland taxa such as Apiaceae, Poaceae, Phormium, and Sarcocornia are present but rare (each $<1 \%)$.

\section{Zone 8: 75-35m depth}

Zone 8 has a similar floristic composition to Zone 7; however, a gap of $55 \mathrm{~m}$ in the pollen record warrants a separate description. Pollen from Metrosideros (23\%), D. cupressinum (15\%), Podocarpus sp. (10\%) and Fuscospora-type (10\%) is most abundant in this zone. Other tree taxa present include $D$. dacrydioides (4\%), P. taxifolia (3\%), Metrosideros (3\%), Weinmania (2\%), P. acutifolius (1\%), and P. totara (1\%). Spores from tree ferns Cyathea-type, Dicksonia-type, and monolete fern spores appear over-represented in this zone (each 10-18\%). Small trees and shrubs are less abundant in this zone than tree taxa. Those present include Halocarpus, Ascarina, Aristotelia, Griselinia, Pittosporum, Pseudopanax, Leptospermum, Coprosma, and Epacridaceae (each 2-3\%). However, Asteraceae has its highest occurrence in the borehole reaching $12 \%$ mean relative abundance at $74 \mathrm{~m}$ depth. Herb taxa are also less common, only Apiaceae and Poaceae make notable appearances (each 2-3\%), whereas wetland taxa including Phormium, and Callitriche are present but rare (each $<1 \%)$.

\section{Zone 9: 32-30m depth}

Zone 9 differs remarkably from previous zones, being characterised by a complete absence of typical tree pollen and the complete dominance of spores from tree ferns Cyathea-type (30\%), Dicksonia-type (8\%), and monolete fern spores (61\%). The only pollen present are from D. cupressinum and Asteraceae (each $<1 \%$ ). 


\section{Zone 10: 26-23m depth}

Similar to Zone 9, this zone is nearly completely dominated by monolete fern spores $(82 \%)$. However, this zone differs from the former as it contains minute proportions of pollen and spores from Asteraceae (5\%), Fuscospora-type (2\%), N. menziesii (3\%), D. cupressinum (3\%) and Cyathea-type (3\%). Other pollen species present include $P$. taxifolia, Podocarpus sp., Apiaceae, Brassicaceae, and Poaceae (each <1\%).

\subsection{RECONSTRUCTIONS OF PAST VEGETATION}

Interpretation of the pollen assemblages is based on regional modern and fossil pollen studies from the New Zealand region (e.g. McKellar, 1973; Macphail and McQueen, 1983; Bussell and Pillans, 1997; McGlone, 2001). It also takes into account factors affecting the representation of pollen and spores such as pollen productivity and depositional environment.

Spores from tree ferns Cyathea-type and Dicksonia-type, and monolete fern spores are dominant throughout the vegetation profile and always make up nearly $50 \%$ of the pollen sum (Fig. 6.2). However, this cannot be taken as implying that tree ferns were the dominant vegetation growing in the region, but probably composed a portion of the contemporary vegetation. Similarly, Nothofagus fusca-type pollen is always present throughout the pollen profile (Fig. 6.2). Therefore, in this study it is determined that beech forests were always present in SW North Island, and proportions of these in the pollen sum are not accurate indicators of forest size.

Pollen and spores in Zone 1 were deposited in a deep marine environment based on facies analysis and microfossil paleoecology (i.e. section 4.3.6), and therefore most likely records a regional vegetation signal (e.g. McGlone, 2001). The regular occurrence of tree pollen from podocarps and broad leaved conifers suggests conifer broad leaved forests were most dominant and grew north of the Horowhenua. The main species included Metrosideros, D. cupressinum, and Podocarpus sp. However, the exact abundance of podocarps is uncertain as less dense bissacate pollen often becomes concentrated in deep marine environments due to selective sorting (e.g. Holmes, 1994; 
Heusser, 1988). The forest also contained Ascarina that is intolerant of water deficits and light frosts and is generally found in sheltered sites within dense podocarphardwood or beech forest canopy cover (McGlone and Moar, 1977). Small amounts of Fuscospora in this zone may represent distal beech forests that grew elsewhere in the region as Nothofagus trees are large produces of pollen that are often transported long distances by wind (McKeller, 1973; McGlone and Topping, 1983; Macphail and McQueen, 1983). However, N. menziesii may have grown in not to distant upland vegetation in montane to sub-alpine environments as it is a somewhat poorer producer of pollen (Pocknall, 1978; Macphail and McQueen, 1983).

Zone 2 records an expansion of Fuscospora, N. menziesii, and shrubs, and a reduction in broad leaved conifers, although $D$. cupressinum remained dominant. There is little change in depositional conditions between zones 1 and 2, so the increase in beech pollen is probably a reflection of forest growth rather than depositional environment. The prevalence of Nothofagus-group and D. cupressinum indicates hardwood and beech forests grew north of the Horowhenua (e.g. Pillans et al., 1988; Bussell and Pillans, 1997). At the same time, patches of conifer-broad leaved forest may have occupied lower lying coastal regions. The increase in pollen from small trees and shrubs in this zone occurred at an expense to larger podocarps, which may represent an expansion of scrubland vegetation. Also notable is the disappearance of A. lucida in this zone.

The increase in pollen from podocarps and broad leaved conifers in Zone 3 suggests podocarp-hardwood forests expanded at this time, which was accompanied by a decline in beech forest and scrubland vegetation. However, an expansion of Nothofagus trees, D. cupressinum, and shrub taxa in the latter part of Zone 3 and in Zone 4 may have produced a hardwood and beech forest and scrubland vegetation (e.g. Bussell and Pillans, 1997). These forests most likely grew north of the Horowhenua, which was underwater. Frost intolerant Ascarina reappears at the top of Zone 3, although it slowly declines again in its latter part and in Zone 4.

Zone 5 records a decrease in Fuscospora-type and shrub taxa and increase in $D$. cupressinum and Metrosideros. This change in pollen assemblage represents an expansion of conifer broad leaved forests and reduction in beech forest and scrubland 
(e.g. Mildenhall, 1979; McGlone et al., 1984; Dunbar et al., 1997). It is uncertain if beech forests remained prevalent in the region at this time as these species are large producers of pollen which frequently gets transported large distance by wind (Moar, 1970; McKellar, 1973; Macphail and McQueen, 1983). The reappearance of Ascarina supports the redevelopment of a densely forested landscape as this species commonly occupies sheltered sites within dense forest canopy covers (McGlone and Moar, 1976).

The large increase in Fuscospora, shrub and grass pollen, and reappearance of $N$. menziesii in Zone 6 indicates an expansion of beech forest and scrubland-grassland vegetation compared to Zone 5. However, the prevalence of D. cupressinum and Metrosideros suggests conifer broad leaved forests may have continued growing in lowland coastal sites. Alternatively, beech forest may have expanded elsewhere in the central North Island as this group is a large produced of pollen that can get transported large distances by wind (Moar, 1970; McKellar, 1973; Macphail and McQueen, 1983). Consequently pollen from both forest types is represented in this zone.

Zone 7 saw the elimination of Fuscospora and increase in broad leaved conifers, namely $D$. cupressinum and Metrosideros. This change in pollen assemblage indicates a reduction in beech forest and expansion of conifer broad leaved forests compared to Zone 6 (Mildenhall, 1979; McGlone et al., 1984; Mildenhall, 1994). An increase of wetland taxa such as Chenopodium, Phormium, and Myriophyllum in this zone indicates an expansion of swamps and sedgeland (e.g. Macphail and McQueen, 1983; McGlone, 1989). Chenopodium prefers saline environments and their occurrence usually indicates the presence of estuaries (Macphail and McQueen, 1983).

The diverse assemblage of podocarps, broad leaved conifers, small trees, and shrubs represented in Zone 8 is indicative of a diverse podocarp-conifer broad leaved forest similar to present day lowland forests (e.g. Dawson, 2000). The presence of Fuscospora-type in this zone also suggests beech forest also grew within the region. However, this group is a large producer of pollen (e.g. Moar, 1970; McKellar, 1973) and the relatively low abundance of these grains suggests beech forest growth was far less extensive than conifer broad leaved forests. 
The almost complete domination of fern spores in Zone 9 is unusual as no typical tree pollen species have been represented. Although, since tree ferns (i.e. Cyathea-type and Dicksonia-type) have been included in the same sum as conifer broad leaved trees (Table. 6.1), the pollen sum (Fig. 6.2) depicts a fully forested landscape. However, the tree pollen components is absent in this zone. It is possible fern spores were sourced from forests growing within the catchment of the Ohau River and were hydraulically transported to the drill site and deposited in overbank deposits. However, wind pollinated tree species from these forests should also be present. It is therefore postulated that the fern spores came from old soil deposits located within the Ohau River catchment, which was unvegetated, where other pollen species had been degraded through biological activity (e.g. Bryant et al., 1994). An example of this is provided by Dunbar et al. (1997) who found that in a study of sediments in Wellington Harbour, pollen assemblages from non-forested areas drained by the Hutt River were dominated by fern spores. A similar scenario is inferred here and Zone 9 probably represents a treeless landscape.

Total tree pollen count was low in Zone 10, which is typical of fluvial deposited pollen spectra, where smaller, less robust pollen grains have been winnowed away (e.g. Moore et al., 1991). However, the minute proportions of pollen from broad leaved conifers, beech, small tree, and herb taxa in this zone indicate a partially forested landscape. The main components were $D$. cupressinum and $N$. menziesii, which probably grew in small clumps on stable parts of the Horowhenua plain, but were relatively rare as the landscape was dominated by coarse-grained fluvial deposition (e.g. deposition of Facies $\mathrm{G})$.

\subsection{RECONSTRUCtions OF PAST CLIMATE (refer to Fig. 6.4)}

Reconstructions of past climate was based on comparing fossil assemblages found in this study to those known from specific climatic periods in the New Zealand region (e.g. McIntyre, 1963; Harris, 1963; McGlone et al., 1984; Mildenhall, 1994; McGlone, 2002) (cf. Table 2.2). The reconstruction also uses the modern distribution of the present day species (e.g. Dawson, 2000), and the distribution of taxa that have precise environmental requirements as indicator species (e.g. Moore and Webb, 1989). 
Ascarina lucida is a good example of the latter, which is intolerant of dry climates and frosts (McGlone and Moar, 1977).

The conifer-broadleaved forest represented in Zone 1 is typical of interglacial pollen assemblages found in Pleistocene strata in SW North Island (cf. Harris, 1963; McGlone et al., 1984; Mildenhall, 1991; Bussell and Pillans, 1997). The forest is also similar to present day vegetation found near sea level in coastal regions of the North Island, which are indicative of hot and moist conditions (Dawson, 2000). The expansion of beech forest in Zone 2 may indicate deterioration in climate and overall cooling trend. At present, similar Nothofagus forests are only found above $600 \mathrm{~m}$ altitude on North Island (Dawson, 2000) and depression in vegetation zones may imply a drop in mean annual temperature (e.g. Pillans et al., 1988; Heusser and van de Geer, 1994). Similarly, an upward increase of $N$. menziesii in this zone suggests an increase in precipitation (e.g. McIntyre, 1963; Macphail and McQueen, 1983).

Zone 2 pollen assemblage is typical of glacial-age sites near sea level in the area, but not of full glacial conditions due to lower levels of grassland and scrubland vegetation (cf. McIntyre, 1970; Bussell, 1986). Following Zone 2 may have been a glacial or lowstand period, which is not recorded in the borehole as during these times unconformities developed on the inner shelf (Pillans, 1991). For this reason, glacial pollen assemblages are uncommon in shallow marine sediment in Wanganui Basin (Fleming, 1953; Bussell, 1986; Bussell, 1990). In this study, evidence for a glacial unconformity occurs between zones 2 and 3 (228m depth in borehole) that corresponds to a change from outer-shoreface to inner-shoreface sedimentation (i.e. Facies FZS to FS), and where an abrupt warming is superimposed on a gradual cooling trend (Fig. $6.5)$.

The replacement of beech forests by podocarp-hardwood forests at the beginning of Zone 3 is characteristic of a stadial-interstadial transition. A similar transition and pollen assemblage has been found in strata in Wanganui Basin and at Ararata in Taranaki that were deposited during OIS 7c (Pillans et al., 1988; Bussell and Pillans, 1997). However, if a glacial unconformity exists between Zone 2 and 3 then this boundary will actually represent an interglacial transition. 


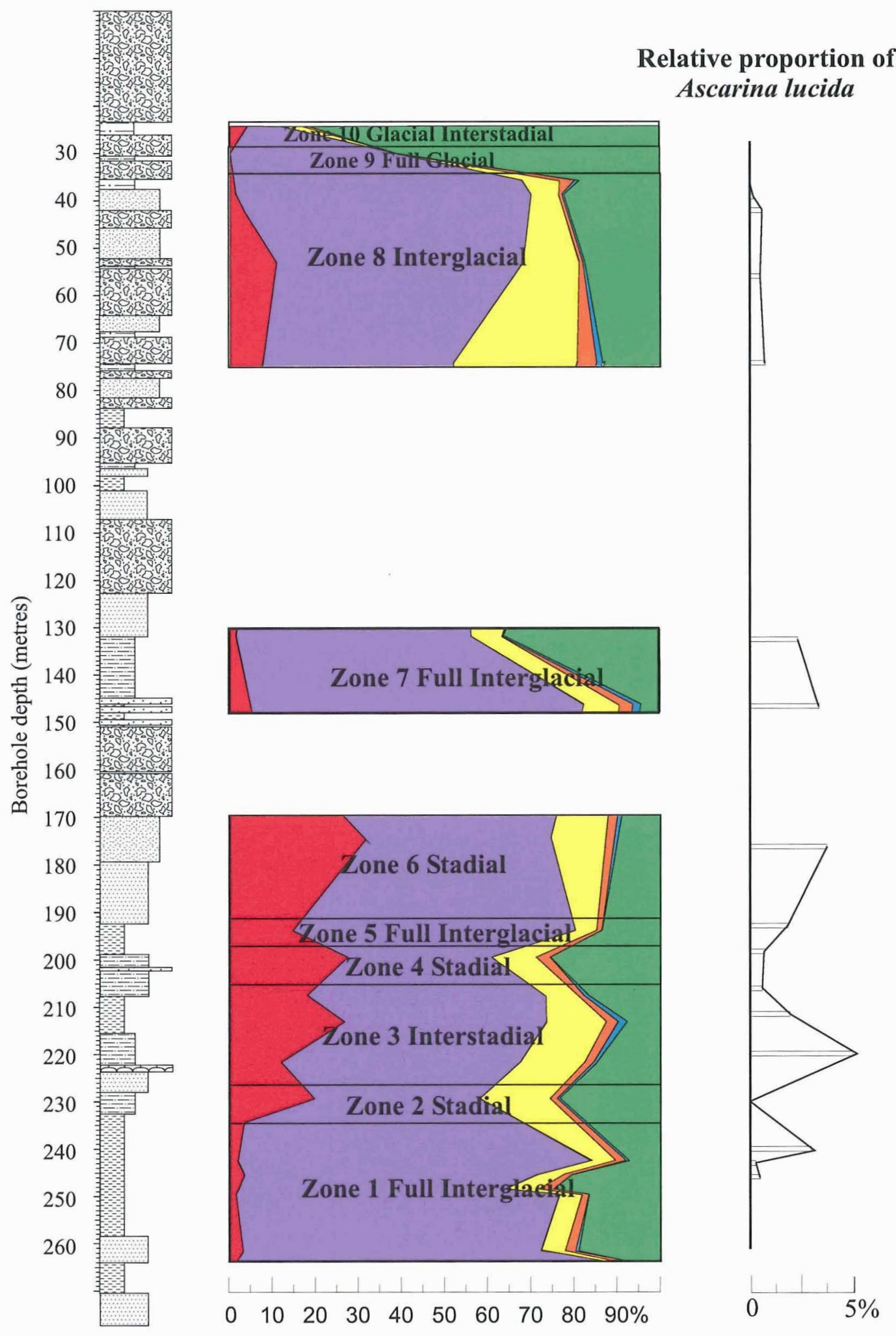

Figure 6.4: Climatic interpretation of pollen data based on pollen zonation and Ascarina lucida. Each zone represents either a 'Hot' interglacial, 'warm' interstadial, 'cool' stadial, or 'cold' glacial period (Refer to Table 6.3). Also shown is position of relative sea level inferred from cyclostratigraphy. (Refer to Fig. 6.2 for key). 
The reappearance of Ascarina in Zone 3 supports redevelopment of a moist-warm climate, which are characteristic of interglacial conditions (McGlone and Moar, 1977).

A deterioration of climate and possible interstadial-stadial transition is recorded between the latter part of Zone 3 and in Zone 4. This interpretation is based on an expansion of scrubland vegetation and beech forest that produced a hardwood and beech forest. Similar hardwood-beech forests grew in the central North Island during brief stadials that pervaded the last two interglacial periods such as during OIS $7 \mathrm{~b}$ (McGlone et al., 1984; McGlone and Topping, 1985; Pillans et al., 1988). In some cases an expansion of beech forest has been correlated to a drop in mean annual temperature (Heusser and van de Geer, 1994; Bussell and Pillans, 1997). In addition, this transition may have been wetter as indicated by an upward increase of $N$. menziesii in this zone (cf. McIntyre, 1963; Macphail and McQueen, 1983; Dawson, 2000).

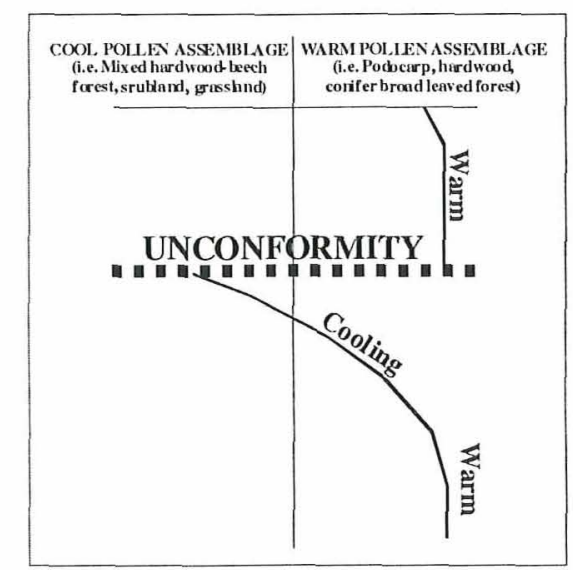

Figure 6.5: Theoretical diagram illustrating where lowstand erosional unconformities can be placed in the borehole where an abrupt warming is superimposed on a gradual cooling trend as indicated by pollen data.

An expansion of conifer broad leaved forest, reduction in scrubland vegetation, and reappearance of Ascarina in Zone 5 records a climate amelioration and possible stadialinterstadial transition. Climate reconstruction maybe comparable to the Early Holocene (c.15ka ago) in the Wellington Region, where taxa such as D. cupressinum and Ascarina increased up to six times at an expense of beech and scrubland vegetation (Mildenhall, 1979; Mildenhall, 1994; Dunbar et al., 1997). A similar vegetation transition has also been noted between OIS $7 \mathrm{~b}$ and $7 \mathrm{a}$ in deep marine cores from around 
the New Zealand region (Heusser and van de Geer, 1994; McGlone, 2001) and in shallow marine strata at Wanganui Basin and Taranaki (Pillans et al., 1988; Bussell and Pillans, 1997).

The considerable expansion of beech forest and scrubland-grassland in Zone 6 records a climate deterioration and overall cooling trend (McGlone et al., 1984; Mildenhall, 1994; McGlone, 2002). At present, similar Nothofagus forests are only found above $600 \mathrm{~m}$ altitude on North Island (Dawson, 2000); where depression in vegetation zones may imply a drop in mean annual temperature (e.g. Pillans et al., 1988; Heusser and van de Geer, 1994). However, the prevalence of Ascarina indicates climate did not cool enough to cause frosts and was relatively moist (McGlone and Moar, 1977). Strata above Zone 6 contains $20 \mathrm{~m}$ thick coarse-grained gravel (Litho-unit 16) that were unable to yield pollen and were possibly deposited under glacial conditions as indicated by sedimentological evidence (Facies IGM). With this in mind, Zone 6 most likely records an interglacial-glacial transition and the overlying gravel strata were deposited during coldest glacial conditions.

Above the gravel strata, Zone 7 records a reappearance of conifer broad leaved forest and the near disappearance of scrubland-grassland and Nothofagus vegetation. This zone is interpreted as an interglacial pollen assemblage, where conditions may have been slightly warmer than the present day ( $c f$. Mildenhall, 1991; Bussell, 1990; Bussell, 1993). Consequently, this supports a glacial origin for the underlying gravel strata. Pollen from Chenopodium found in this zone indicates estuaries developed as this time as they are predominantly salt water inhabitants (Macphail and McQueen, 1983). Since it is generally accepted that estuaries develop from coastal submergence (e.g. Curray, 1964; Boyd et al., 1992), deposition of pollen in this zone may have corresponded with a transgression.

A gap in the pollen record occurs between 130-75m depth and pollen zones above this are from thin sand or silt units that are interbedded with thick coarse-grained gravel strata and only provide brief glimpses of climatic conditions. 
Similar to Zone 7, the podocarp-conifer broad leaved forest represented in Zone 8 (75$35 \mathrm{~m}$ depth) is characteristic of interglacial climate conditions (cf. Bussell, 1993; Mildenhall, 1991). The decreasing abundance of Ascarina in this zone maybe comparable to the late Holocene on Kapiti Coast where Ascarina is in decline due to slow deterioration in climate since 5ka ago (Mildenhall, 1979). Ascarina continues to decrease gradually throughout this zone and is absent at the base which implies climate continued to deteriorate further.

As mentioned earlier, glacial pollen sequences within the Wanganui Basin are uncommon as these periods were characterised by lower sea level that resulted in widespread erosion and coarse-grained fluvial deposition (e.g. Fleming, 1953; Pillans, 1991). However, pollen assemblages contained in Zones 9 and 10, taken from thin silt beds in the upper c. $35 \mathrm{~m}$ of borehole strata (e.g. Facies Z), are comparable with glacial climate conditions ( $c f$. McIntyre, 1963; McIntyre, 1970; Pocknall, 1984; Heusser and van de Geer, 1994; McGlone, 2001). Zone 9 contains pollen and spore assemblage indicative of treeless landscape that represents the coldest climate encountered within the borehole. It is comparable with glacial stadial pollen assemblages from the Kapiti Coast (cf. McIntyre, 1970; Pocknall, 1984). Similarly, Zone 10 represents a partially forested landscape also dominated by grassland-scrubland vegetation. However, this zone represents a slight climate amelioration and milder climate than Zone 9, which was cooler and wetter than the present day. It is comparable with glacial interstadial conditions ( $c f$. McIntyre, 1963).

\subsection{SUMMARY OF VEGETATION AND CLIMATE RECONSTRUCTIONS}

Reconstruction of past vegetation and climate in the Levin borehole has revealed at least three interglacial and three glacial periods have been recorded (Table 6.3). Interglacial pollen assemblages are dominated by podocarp and broad leaved conifer trees that represent structurally diverse forests (e.g. Zones 1, 3, 5, 7, and 8) and are similar to other interglacial pollen assemblage from Wanganui Basin (McGlone et al., 1984; Pillans et al., 1988; Bussell, 1990; Bussell and Pillans, 1997). Stadial periods, which occur during interglacials, are distinguished by Hardwood-, Podocarp-beech forests and scrubland pollen assemblages (i.e. zones 2 , 4, and 6) that are similar to other stadial 
assemblages recognised in SW North Island (Pillans et al., 1988; Bussell and Pillans, 1997) (Table 2.2). These assemblages represent slight climate deteriorations within interglacials, and may indicate a drop in mean annual temperature (Heusser and van de Geer, 1994). Glacial pollen assemblages are uncommon in the borehole as these periods were characterised by sea level lowering and widespread fluvial deposition or erosion that produced unconformities (e.g. Pillans, 1991). However, their location in the sequence can be inferred to lie where an abrupt warming is superimposed on a gradual cooling trend (Fig. 6.5). Examples of such lowstands occur between Zones 2 and 3 (224m depth), Zones 4 and 5 (201m depth), and Zones 6 and 7 (146m depth). Only pollen zones 9 and 10 taken from fluvial strata in the top $35 \mathrm{~m}$ of the borehole indicate glacial conditions, which represent treeless landscapes and scrubland-grassland vegetation ( $c f$. McIntyre, 1970; Pocknall, 1984). If this is true, then the top c.35m of the borehole may represent the Last Glacial Period (c.20-70ka). Mapping projects carried out in the region support a Last Glacial age for the top part of the borehole (e.g. Begg and Johnston, 2000).

Table 6.3: Summary of vegetation and climate reconstructions for Levin borehole.

\begin{tabular}{|c|c|c|c|}
\hline Zone & $\begin{array}{c}\text { Borehole } \\
\text { depth }\end{array}$ & Vegetation & Inferred climate \\
\hline 1 & $263-238 m$ & Conifer-broad leaved forest & Full Interglacial \\
\hline 2 & $233-225 m$ & Hardwood and beech forest & Stadial-cooling \\
\hline 3 & $223-205 m$ & Podocarp-hardwood forest & Interglacial \\
\hline 4 & 201-198m & $\begin{array}{l}\text { Hardwood-beech forest } \\
\text { and scrubland }\end{array}$ & Stadial-cooling \\
\hline 5 & $195-190 \mathrm{~m}$ & Conifer broad leaved forest & Full Interglacial \\
\hline 6 & $182-170 \mathrm{~m}$ & $\begin{array}{l}\text { Conifer broad leaved, beech forest } \\
\text { and scrubland-grassland }\end{array}$ & Stadial-cooling \\
\hline 7 & $147-131 \mathrm{~m}$ & Conifer broad leaved forest & Full Interglacial \\
\hline 8 & $75-35 m$ & $\begin{array}{c}\text { Podocarp-Conifer broad } \\
\text { leaved forest }\end{array}$ & Interglacial-cooling \\
\hline 9 & $32-30 \mathrm{~m}$ & Treeless grassland-scrubland & Full Glacial \\
\hline 10 & $26-23 m$ & Partial hardwood-beech forest & Glacial interstadial \\
\hline
\end{tabular}




\section{CHAPTER 7 \\ BOREHOLE CHRONOLOGY}

\subsection{INTRODUCTION}

The chronology for the Levin borehole sequence has been derived from a range of absolute and relative dating techniques including; radiocarbon dating, lithostratigraphy, biostratigraphy, and tephrochronology. A chronostratigraphic framework is established by correlating borehole strata to marine oxygen isotope stages (OIS) from deep marine cores. This is accomplished by the recognition of key chronologic markers from the Wanganui Basin in the borehole, which have been orbitally tuned to the marine oxygen isotope record (e.g. Beu and Edwards, 1984; Pillans, 1994).

\subsection{LITHOSTRATIGRAPHY}

Lithostratigraphic units described in the Horowhenua District have been extrapolated through the sub-surface into the Levin borehole by tracing their contacts through existing groundwater bores (Fig. 7.1). However, because existing boreholes seldom reach over $100 \mathrm{~m}$ depth, this technique is only useful for correlating strata in the top c. $80 \mathrm{~m}$ of the Levin borehole.

\subsubsection{Ohakean Alluvium (Last Glacial Strata)}

Fluvial strata deposited during the Last Glacial Period (i.e. Porewan, Ratan, and Ohakean Alluvium) are referred to here as the Ohakean Alluvium as these deposits often have indistinguishable sediment characteristics. Line A-A' shows a paleo-river channel incised into the Tokomaru Marine Terrace containing Ohakean Alluvium (OIS 2), which may reflect an old channel of the Ohau River (Fig. 7.1). The base of the alluvium intersects the Levin borehole at about $40 \mathrm{~m}$ depth. A similar depth is inferred from Line B-B' (Fig. 7.1), suggesting the top 40m of the borehole consists of strata deposited during the Last Glacial Period (14-70ka). An age of $>50000$ yrs BP taken from wood found within strata between $26-31 \mathrm{~m}$ depth agrees with this interpretation (Table 7.1). 


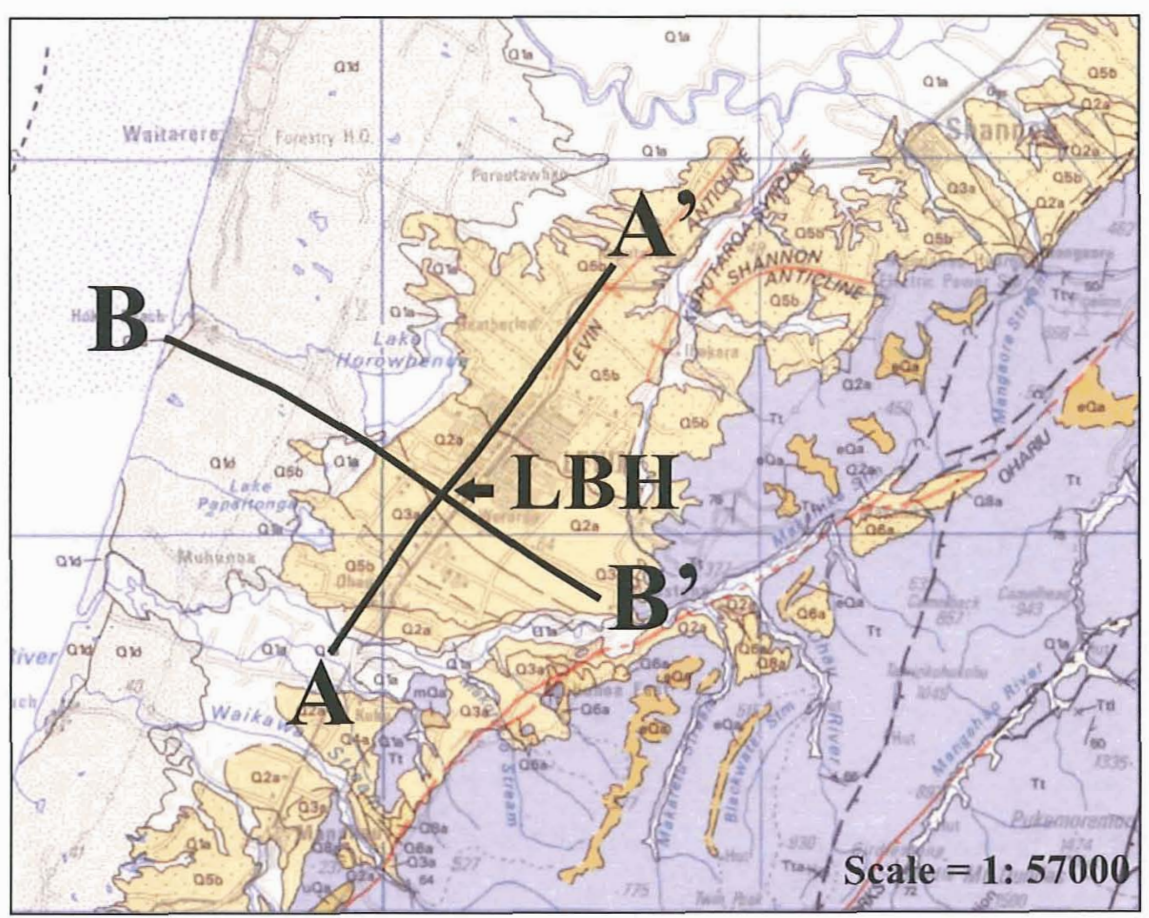

\section{Stratigraphy}

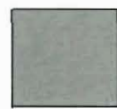

Holocene dunesand/alluvium (OIS 1)

\section{Graphic log}

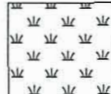

Peat

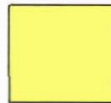

Ohakean Alluvium (OIS 2)

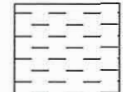

Mud

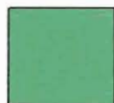

Otaki Formation (dunesand) (OIS 5)

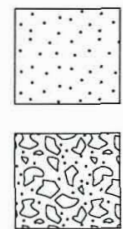

Sand

Gravel

\section{Caption for Figure 7.1: (over page)}

Cross sections running northeast-southwest (Line A-A') along the Horowhenua plain between Ohau (borehole 362095, grid reference 2699700E; 6057400N) and Heatherlea (borehole 353131, grid reference 2705700; 6065800) and southeast-northwest (Line B-B'), perpendicular to line A-A', between East Levin (borehole 363013) and Hokio Beach (borehole 362349) (see map above). Plotted on the cross section are the lithological logs of boreholes that occur within $100 \mathrm{~m}$ to the section line and the top $90 \mathrm{~m}$ of the $\mathrm{LBH}$. Also shown are surface outcrops of Last Interglacial marine strata (Otaki Formation), which comprises the Tokomaru Marine Terrace (Green) (OIS 5); Last Glacial Maximum strata, which comprise the Ohakean Surface (Yellow) (OIS 2); and, Holocene deposits, mainly dune sand (Grey) (OIS 1). Vertical scale is exaggerated to improve accuracy of correlation between boreholes $(1: 1000)$. Horizontal scale is 1:15000. 

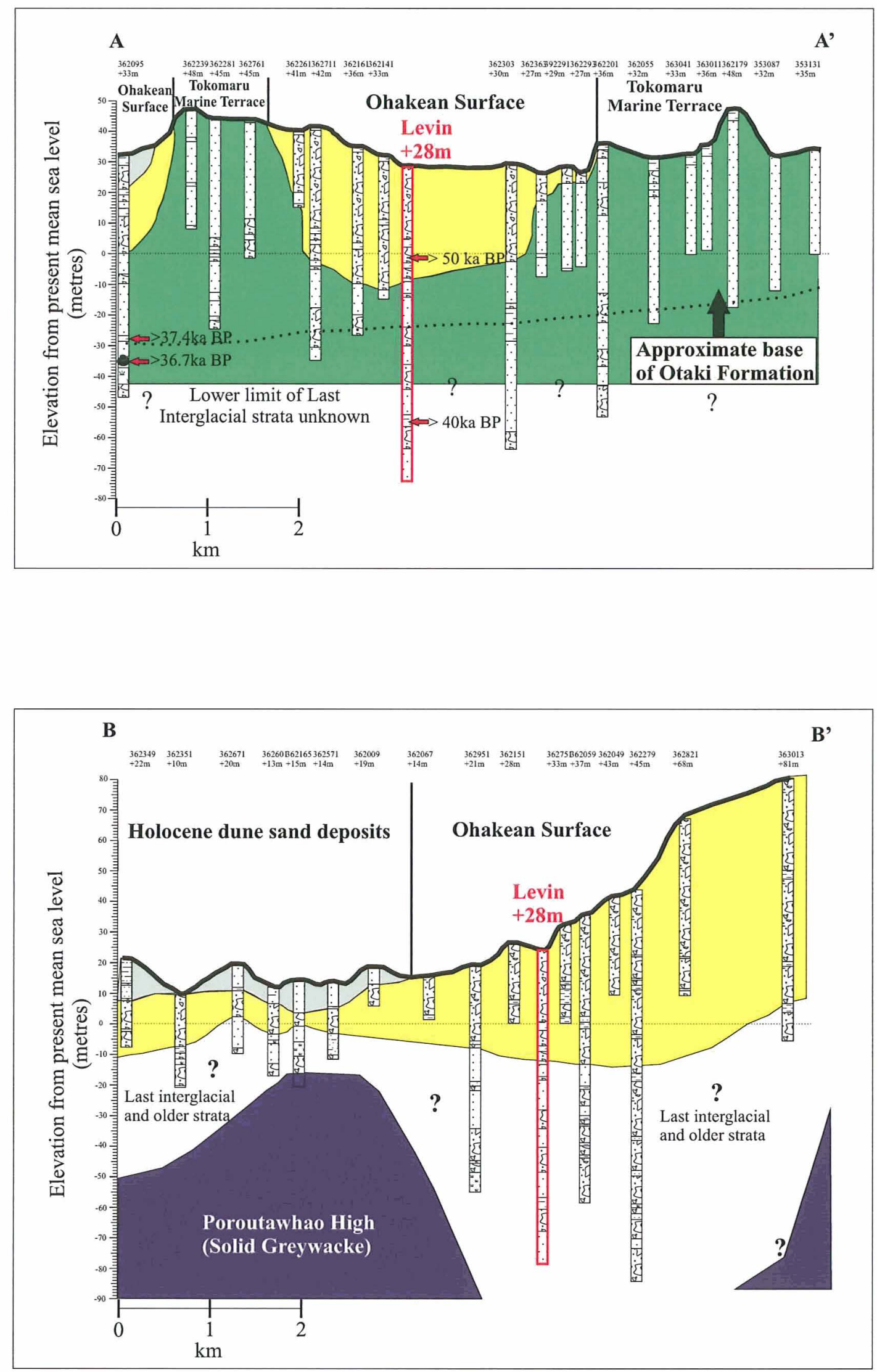

Figure 7.1: Cross sections over the Horowhenua coastal plain. 


\subsubsection{Otaki Formation (Last Interglacial strata)}

The Otaki Formation (OIS 5c-5a) is interpreted to lie stratigraphically below Last Glacial fluvial deposits in the Levin borehole (Fig. 7.1). The contact between the Otaki Formation and Ohakean Alluvium is marked by a distinct change in lithology from brown coarse-grained gravel to grey-brown silt and fine sand deposits, which contains wood dated at $>40000$ yrs BP (Table 7.1). The contact maybe an erosional unconformity as the top c.30m of Otaki Formation appears to have been truncated by the alluvium (Fig. 7.1). The base of the Otaki Formation cannot be accurately determined from the cross sections as its basal contact does not outcrop in the Horowhenua District (e.g. Begg and Johnston, 2000). However, deposits that are correlative with the Otaki Formation have been encountered between $33 \mathrm{~m}$ and $41 \mathrm{~m}$ below sea level in a well less than 3km south of Levin in Ohau (bore 362095; GR S25 997574) (Fig. 7.1). This correlation is based on shell and peat samples that have been dated at $>35700$ yrs BP and $>36300$ yrs BP respectively (Brown, 2003). The base of the Otaki Formation has also been interpreted to lay around $10-15 \mathrm{~m}$ below present sea level in wells north of Levin (Sewell, 1991). Therefore it is suggested the base of the Otaki Formation occurs around 55m depth in the Levin borehole (Fig. 7.1), giving it a minimum thickness of $15 \mathrm{~m}$.

Table 7.1: Summary and significance of radiocarbon dates retrieved during this study (App. F)

\begin{tabular}{|c|c|c|c|c|}
\hline Reference & $\begin{array}{l}\text { Depth of } \\
\text { sample }\end{array}$ & Sample & $\begin{array}{c}\text { Conventional }{ }^{14} \mathrm{C} \\
\text { age (yrs } \mathrm{BP})\end{array}$ & Significance \\
\hline Wk 13830 & $\begin{array}{c}30.5 \mathrm{~m} \\
\text { (litho-unit } \\
34)\end{array}$ & $\begin{array}{l}\text { Wood in brown } \\
\text { gravel and sand. }\end{array}$ & $>50000$ & $\begin{array}{l}\text { Possible last glacial } \\
\text { fluvial deposit. }\end{array}$ \\
\hline Wk 13831 & $\begin{array}{c}75 \mathrm{~m} \\
\text { (litho-unit } \\
23 \text { ) }\end{array}$ & $\begin{array}{l}\text { Wood in dark } \\
\text { brown } \\
\text { carbonaceous } \\
\text { silt. }\end{array}$ & $>40000$ & $\begin{array}{l}\text { Possible last interglacial } \\
\text { swamp deposit. }\end{array}$ \\
\hline
\end{tabular}




\subsection{BIOSTRATIGRAPHIC TIME RANGES}

\subsubsection{Marine molluscs}

The majority of marine molluscs found in the borehole strata first appeared within the Nukumaruan Stage (2.4-1.71Ma) in Wanganui Basin, with some not appearing until the Castlecliffian (1.71-0.34Ma) (Fig. 7.2). For example Chlamys gemmulata, which occurs prominently throughout the lower part of the borehole and is the dominant mollusc present in litho-unit 4, made its first appearance during the Nukumaruan (Beu and Maxwell, 1990) (Fig. 7.2). A lower age limit for the borehole is defined from the gastropod Xymene plebeius (Hutton) and bivalve Tawera spissa (Deshayes), where fresh tests of these occur in shell beds between 224-225m and 199-201m depths. According to Beu and Maxwell (1990) these taxa did not appear until the Castlecliffian and can still be found living in waters around New Zealand (Fig. 7.2). An upper age constraint in the borehole maybe provided by the bivalve Barytellina crassidens (Marwick), which has not been found in marine strata younger than 300ka (OIS 9) in southern North Island (Beu and Maxwell, 1990) (Fig. 7.3). A broken, but relatively fresh test of B. crassidens was found between 224-225m depth (litho-unit 7) (Fig. 7.2). However, this shell bed is interpreted to represent a shoreface-shelf environment based on faunal composition (i.e. Facies SL) and mid-cycle position within Cycle 2, whereas $B$. crassidens is a low-salinity tolerant species. Consequently, B. crassidens has been recognised out of its preferred environment and maybe detrital.

Therefore, the Levin borehole sequence is considered to be younger than the Castlecliffian sub-stage of the Wanganui Series $(<1.71 \mathrm{Ma})$. The strata also maybe younger than $400 \mathrm{ka}$ based on the overall absence of the estuarine dwelling bivalve Pecten marwicki (Finlay), which has a last appearance datum (LAD) of OIS 10 in New Zealand shallow marine deposits (Beu and Maxwell, 1990) (Fig. 7.3). The shell bed located between $224-225 \mathrm{~m}$ depth maybe as old as $300 \mathrm{ka}$ or thereabouts (Fig. 7.2). 


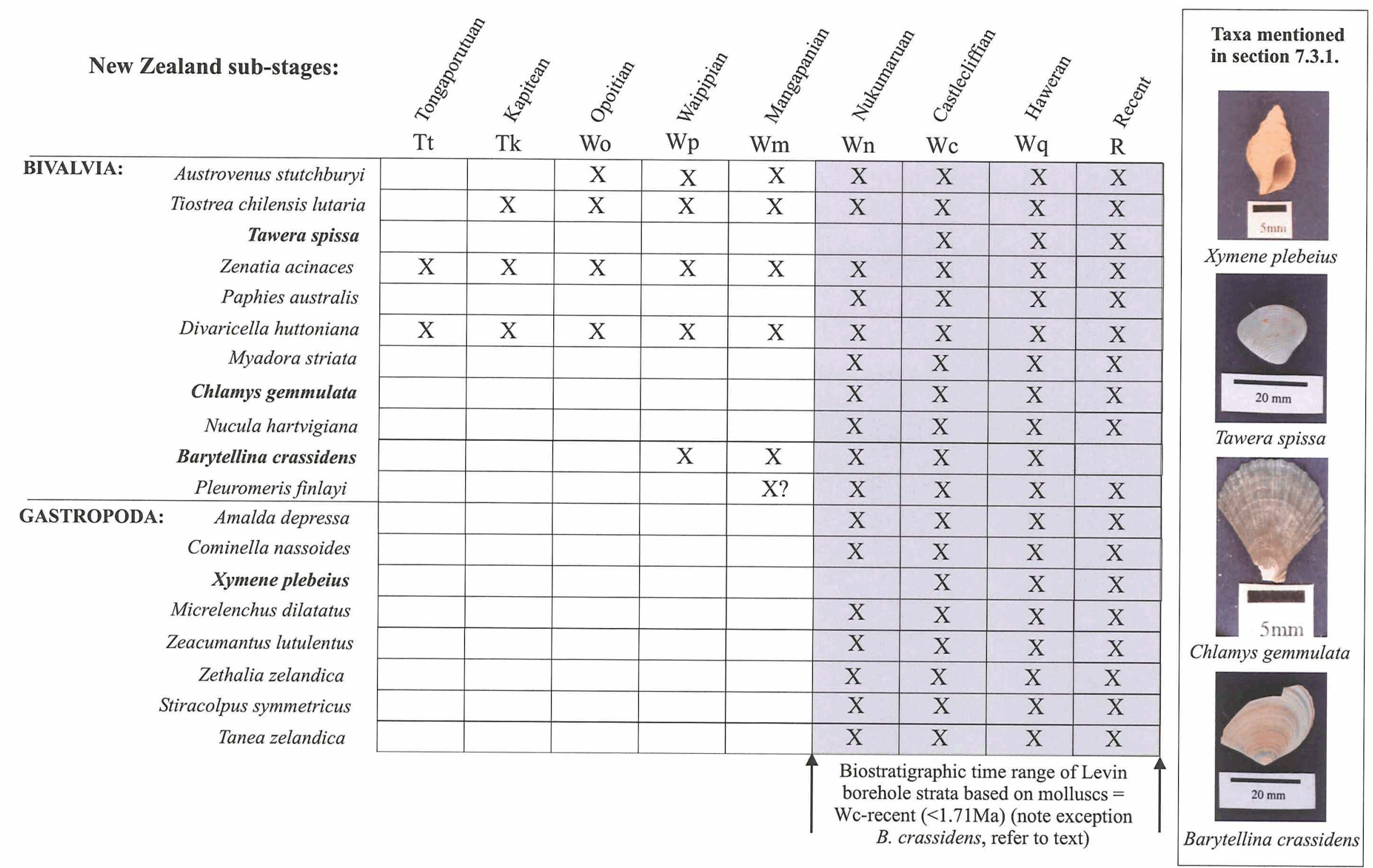




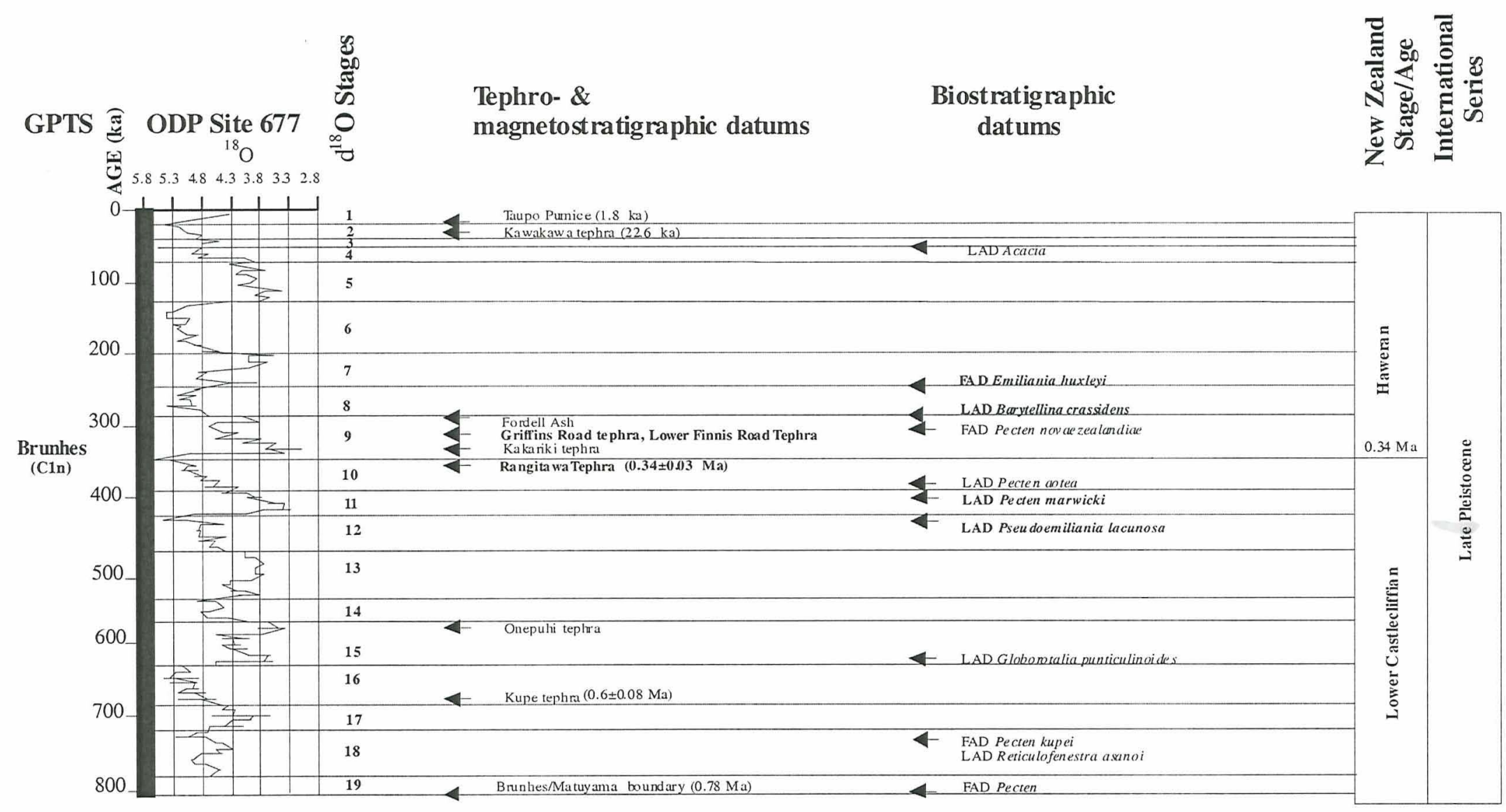

Figure 7.3: Summary of Late Pleistocene chronostatigraphy in Wanganui Basin for last 800ka. Isotope stratigraphy and magnetic polarity timescale after Shackleton et al. (1990). Tephrochronology from Seward (1976), Pill ans (1991), and Alloway et al. (1993). Biostratigraphic datums from Beu and Edwards (1984), Edwards (1987), and Bussell and Mildenhall (1990). Data in bold type 


\subsubsection{Nannofossils}

Four samples taken from 131-132m, 212-213m, 228-229m, and 248-249m depths were analysed for nannofossil assemblages by A. R. Edwards of Stratigraphic Solutions Limited whose complete reports have been included (App. G). Nannoflora in all four samples are from the lower to middle part of the Coccolithus pelagicus Zone (Edwards pers. comm., 2005), which has a biostratigraphic age of upper Castlecliffian to middle Haweran or between oxygen isotope stages 12-3 (c.60-500ka). This age is based on the presence of $C$. pelagicus and absence of Pseudoemiliania lacunosa that has a first appearance datum (FAD) of OIS 12 (c.500ka) (Beu and Edwards, 1984) (Fig. 7.3). In addition, nannoflora assemblages in all samples are consistent with deposition during interglacial conditions (Edwards, pers comm., 2005), which indicates they are either from OIS 5, 7, 9, or 11. Samples from 131-132m and 212-213m depth contain Emiliania huxleyi that first appeared in marine cores during OIS 8 (c.300ka) (Beu and Edwards, 1984; Edwards, 1987) (Fig. 7.3), therefore suggesting OIS 5 or 7 (70-245ka) are more likely. By contrast, samples from 228-229m and 248-249m depth do not contain E. huxleyi indicating OIS 11 or 9 (c.300-400ka) are a likely age for these depths.

\subsection{TEPHROCHRONOLOGY}

Geochemical analysis using electron microprobe analysis (e.g. Froggatt, 1983) was performed on glass shards found in six samples (App. H). Seven possible tephras were found, which formed tightly spaced clusters on plots of major oxide concentrations indicating a similar geochemistry (labelled A, B, C, D, E, F, and G) (Fig. 7.4). Two of the samples taken from between 199-200m and 259-260m depths contained no distinct tephras. All of the tephras are composed of multiple glass shard populations and are not considered to be primary air fall deposits, and therefore will only provide maximum ages for the borehole. Values of $\mathrm{FeO}, \mathrm{CaO}, \mathrm{SiO}_{2}$, and $\mathrm{K}_{2} \mathrm{O}$ were found to vary the most, and biaxial plots of these were used to correlate tephras from the borehole to known tephras from the Wanganui Basin (e.g. Froggatt, 1983; Shane et al., 1996) (Table 7.2; Fig. 7.3). 

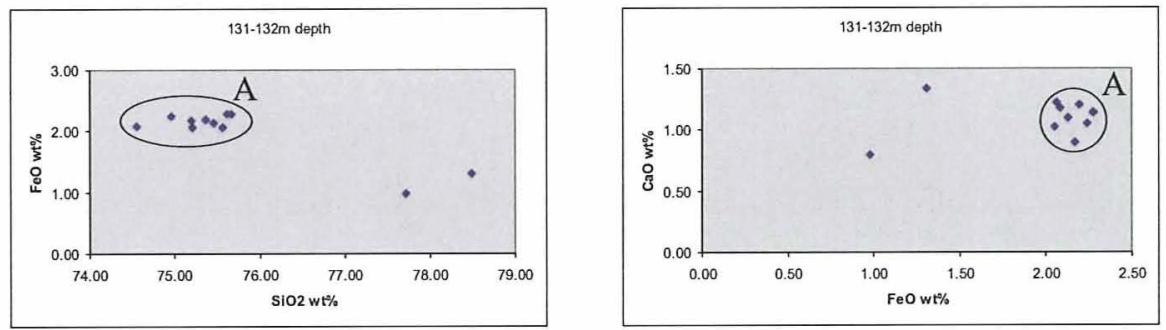

One tephra (A), two outsiders
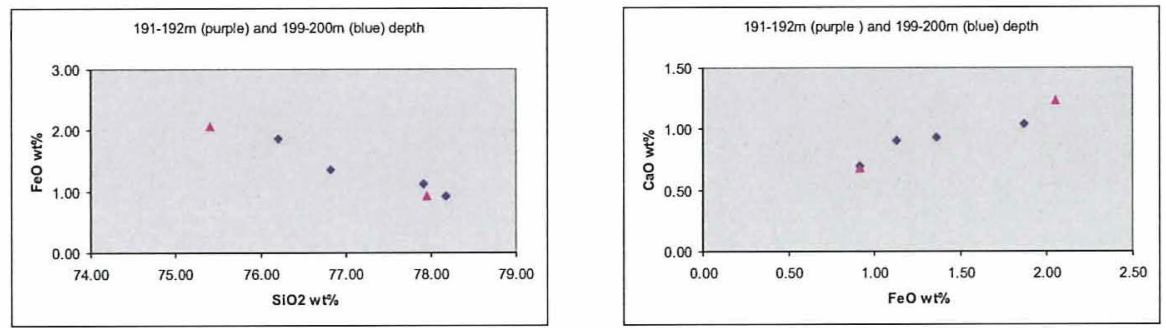

Multi-population, unidentifiable shards
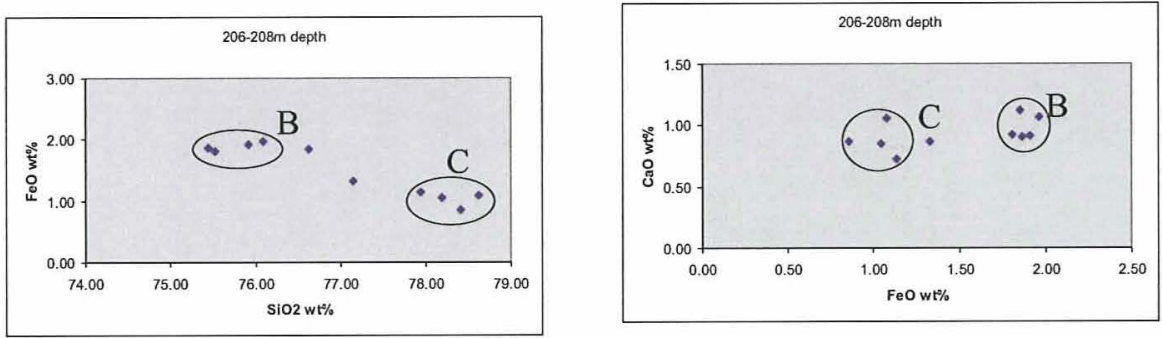

B

$\mathrm{SiO}_{2} \quad 75.91(0.47)$ $\mathrm{Al}_{2} \mathrm{O}_{3} 13.35(0.19)$

$\begin{array}{ll}\mathrm{TiO}_{2} & 0.17(0.03)\end{array}$

$\mathrm{FeO} \quad 1.87(0.06)$

$\mathrm{MnO} \quad 0.07(0.04)$

$\mathrm{MgO} 0.10(0.05)$

$\mathrm{CaO} \quad 0.98(0.10)$

$\mathrm{Na}_{2} \mathrm{O} \quad 3.24(0.21)$

$\mathrm{K}_{2} \mathrm{O} \quad 4.06(0.60)$

$\mathrm{Cl} \quad 0.21(0.05)$

C

$78.05(0.57)$

$12.59(0.33)$

$0.10(0.03)$

$1.08(0.16)$

$0.06(0.05)$

$0.11(0.03)$

$0.87(0.11)$

$2.97(0.35)$

$3.90(0.14)$

$0.22(0.03)$

Possible two tephras (B and $\mathrm{C})$
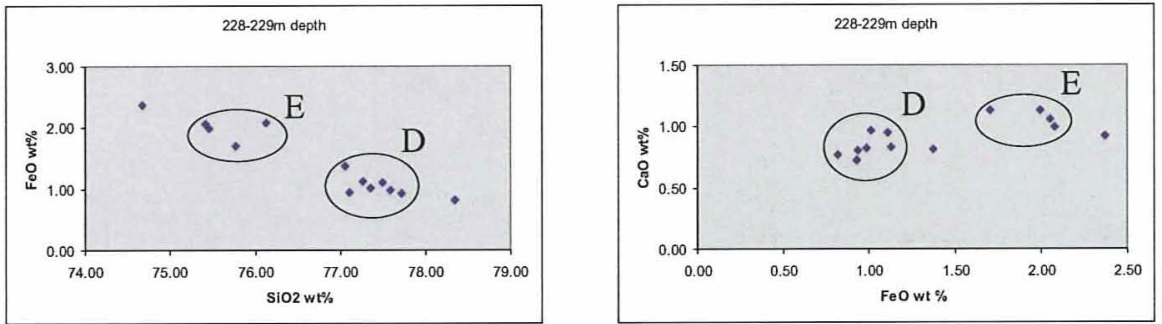

$\mathrm{SiO}_{2} \quad 77.55(0.40)$

A $12.84(0.24)$

$\begin{array}{ll}\mathrm{TiO}_{2} & 0.13(0.04)\end{array}$

$\mathrm{FeO} \quad 0.98(0.10)$

$\mathrm{MnO} \quad 0.08(0.03)$

$\mathrm{MgO} \quad 0.09(0.01)$

$\mathrm{CaO} \quad 0.84(0.08)$

$\mathrm{Na}_{2} \mathrm{O} \quad 3.11(0.19)$

$\mathrm{K}_{2} \mathrm{O} \quad 4.10(0.19)$

$\mathrm{Cl} \quad 0.23(0.03)$

$75.69(0.32)$

$13.89(0.17)$

$0.16(0.04)$

$1.95(0.17)$

$0.13(0.02)$

$0.09(0.03)$

$1.07(0.06)$

$3.20(0.14)$

$3.56(0.03)$

$0.20(0.05)$

Two tephras ( $\mathrm{D}$ and $\mathrm{E}), \mathrm{D}$ is most prominent and maybe primary
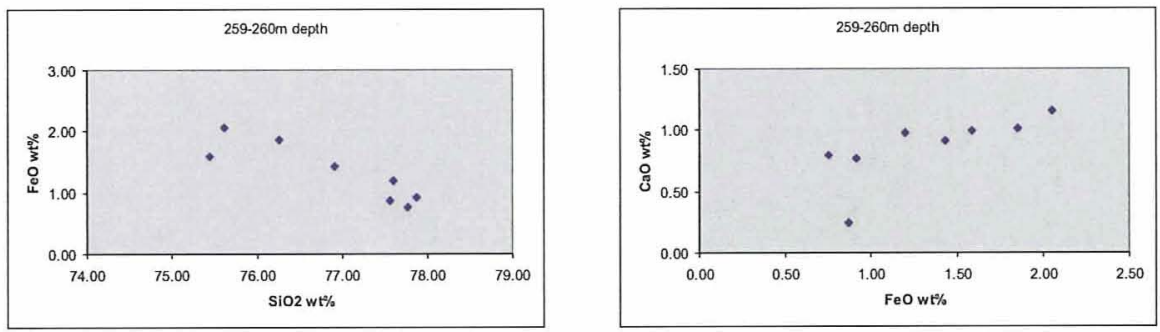

Multi-population, unidentifiable shards
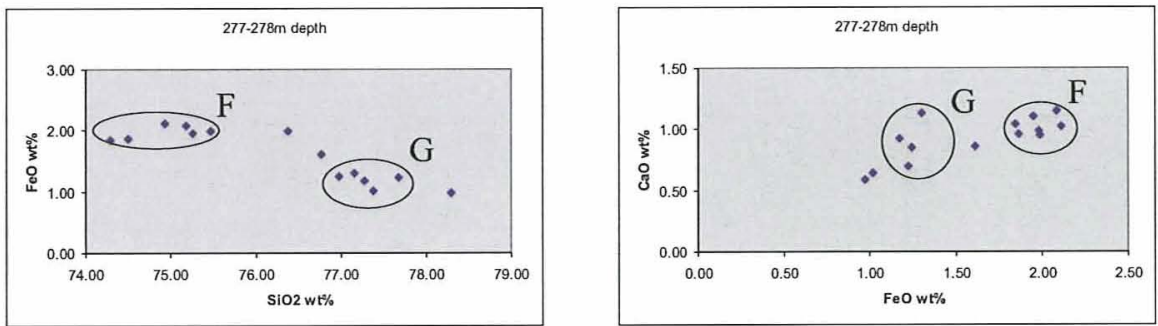

F

$\mathrm{SiO}_{2} \quad 75.14(0.68)$

$\mathrm{Al}_{2} \mathrm{O}_{3} \quad 13.72(0.22)$

$\mathrm{TiO}_{2} \quad 0.16(0.04)$

$\mathrm{FeO} \quad 1.97(0.10)$

$\mathrm{MnO} \quad 0.04(0.04)$

$\mathrm{MgO} \quad 0.09(0.02)$

$\mathrm{CaO} \quad 1.02(0.07)$

$\mathrm{Na}_{2} \mathrm{O} \quad 3.37(0.43)$

$\mathrm{K}_{2} \mathrm{O} \quad 4.26(0.59)$

$\begin{array}{ll}\mathrm{Cl} & 0.18(0.02)\end{array}$

\section{G}

$50(0.50)$

$12.97(0.32)$

$0.10(0.03)$

$1.12(0.12)$

$0.05(0.04)$

$0.10(0.02)$

$0.73(0.14)$

$3.19(0.45)$

$3.94(0.44)$

$0.24(0.02)$

Possible two tephras (F and G), and several unidentifiable shards

Figure 7.4: $\mathrm{Biaxial}$ plots $\left(\mathrm{CaO} / \mathrm{FeO}\right.$ and $\left.\mathrm{SiO}_{2} / \mathrm{FeO}\right)$ showing seven tephra clusters in the Levin borehole.

Also shown are average normalised major oxide values and standard deviations (in brackets). 
Table 7.2: Summary of geochemistry and ages for Late Pleistocene Tephra beds, North Island, New Zealand

\begin{tabular}{|c|c|c|c|c|c|c|c|c|c|c|c|c|}
\hline Tephra & $\mathrm{SiO}_{2}$ & $\mathrm{Al}_{2} \mathrm{O}_{3}$ & $\mathrm{TiO}_{2}$ & $\mathrm{FeO}$ & $\mathrm{MnO}$ & $\mathrm{MgO}$ & $\mathrm{CaO}$ & $\mathrm{Na}_{2} \mathrm{O}$ & $\mathrm{K}_{2} \mathrm{O}$ & $\mathrm{Cl}$ & $\mathrm{H}_{2} \mathrm{O}$ & AGE (ka) \\
\hline Rangitatau^ & $78.30(0.53)$ & $12.15(0.11)$ & $0.12(0.05)$ & $1.02(0.08)$ & - & $0.14(0.03)$ & $0.95(0.12)$ & $3.28(0.30)$ & $3.96(0.25)$ & $0.08(0.04)$ & $3.63(0.98)$ & c. $240-300 \mathrm{sC} \#$ \\
\hline Upper Griffin Road^ & $77.71(0.38)$ & $12.20(0.24)$ & $0.11(0.02)$ & $1.41(0.20)$ & - & $0.08(0.04)$ & $0.90(0.15)$ & $4.05(0.09)$ & $3.45(0.20)$ & $0.10(0.03)$ & $6.32(0.69)$ & $?$ \\
\hline Middle Griffin Road^ & $78.20(0.37)$ & $12.09(0.20)$ & $0.10(0.02)$ & $1.16(0.10)$ & - & $0.07(0.02)$ & $0.80(0.10)$ & $3.94(0.16)$ & $3.55(0.24)$ & $0.08(0.03)$ & $5.62(0.81)$ & $?$ \\
\hline Lower Griffin Road^ & $76.76(0.29)$ & $12.75(0.18)$ & $0.25(0.05)$ & $1.27(0.07)$ & - & $0.26(0.05)$ & $1.14(0.10)$ & $4.11(0.13)$ & $3.10(0.23)$ & $0.10(0.03)$ & $5.60(0.78)$ & $?$ \\
\hline Fordel1^ & $78.28(0.22)$ & $11.80(0.10)$ & $0.10(0.04)$ & $1.07(0.08)$ & - & $0.05(0.03)$ & $0.57(0.08)$ & $3.98(0.12)$ & $3.99(0.12)$ & $0.17(0.04)$ & $6.16(0.02)$ & c. $320 \mathrm{sC \#}$ \\
\hline Lower Finnis Road & $76.50(0.68)$ & $12.38(0.33)$ & $0.17(0.05)$ & $1.94(0.31)$ & - & $0.11(0.03)$ & $1.08(0.15)$ & $4.38(0.32)$ & $3.39(0.43)$ & - & $5.90(1.62)$ & $320 \pm 70^{*}$ FT Zircon \\
\hline Lower Kakariki ${ }^{\dagger}$ & $75.01(0.41)$ & $13.22(0.15)$ & $0.16(0.02)$ & $2.01(0.13)$ & - & $0.10(0.03)$ & $1.05(0.11)$ & $4.27(0.18)$ & $4.00(0.46)$ & $0.18(0.03)$ & - & $<350 \mathrm{sc}$ \\
\hline Mt Curl' (=Rangitawa) & $77.81(0.42)$ & $12.57(0.28)$ & $0.13(0.03)$ & $1.10(0.09)$ & $0.03(0.03)$ & $0.10(0.04)$ & $0.78(0.04)$ & $3.50(0.09)$ & $4.00(0.20)$ & - & $6.02(1.18)$ & $340 \pm 30$ \# FT Zircon \\
\hline Rangitawa $^{5}$ & $78.15(0.32)$ & $12.41(0.19)$ & $0.14(0.04)$ & $0.97(0.10)$ & $0.00(0.00)$ & $0.12(0.03)$ & $0.80(0.06)$ & $3.21(0.15)$ & $4.22(0.14)$ & $0.00(0.00)$ & $4.83(2.73)$ & $350 \pm 40$ ITPFT \\
\hline Kupe' & $77.58(0.37)$ & $12.10(0.17)$ & $0.14(0.03)$ & $1.29(0.12)$ & - & $0.10(0.04)$ & $0.91(0.09)$ & $3.80(0.16)$ & $3.84(0.13)$ & $0.24(0.05)$ & $3.88(0.71)$ & $640 \pm 80 \mathrm{FT}$ \\
\hline
\end{tabular}

Proportions of macroclements (wt\%) determincd from microprobc analysis of glass shards. Means and standard deviations (in brackets) cxpressed from $n$ analysis (see orginal sources below). Recalculated to $100 \%$, water by difference, all $\mathrm{Fe}$ as FeO. - = no reading. Dates produced using either isothermal plateau fission-track method (ITPFT), Fission track method (FT), or by stratigraphic correlation (SC).

\author{
'Data from Milne (1973) \\ ${ }^{\dagger}$ Data from Bussell (1984) \\ DData from MacPherson (1985) \\ Data from Pillans (1988) \\ *Age from Scward (1976) \\ \#Agc from Kohn et al. (1992) \\ Data from Pillans (1994) \\ Data from Shane (2000)
}




\subsubsection{Unknown Tephra A (131-132m depth)}

Tephra $\mathbf{A}$ is characterised by high values of $\mathrm{FeO}$ (mean 2.16\%) and $\mathrm{CaO}$ (mean 1.10\%), and low values of $\mathrm{K}_{2} \mathrm{O}$ (mean 3.44\%) (Fig. 7.4). The nearest correlatives are either the Lower Finnis Road Tephra, found near Pohangina in Manawatu (Station 17 of MacPherson, 1985), or Lower Kakariki Tephra, found at Rangitawa Stream (Bussell, 1984), which also have high $\mathrm{FeO}$ (Mean >2.0\%) (Table 7.2). However values of $\mathrm{K}_{2} \mathrm{O}$ are too large in these tephras (mean $>4.00 \%$ ) to be exact correlatives.

\subsubsection{Unknown Tephra B and Middle Griffins Road Tephra (Tephra C) (206-208m depth)}

Tephra $\mathrm{B}$ is chemically distinctive being characterised by high $\mathrm{FeO}$ (mean 1.87\%) and high $\mathrm{K}_{2} \mathrm{O}$ (mean 4.06\%) (Fig. 7.4). However, it does not correlate well with any other tephras from the Pleistocene Wanganui Basin, which also have high $\mathrm{FeO}$ (mean $>2.00 \%$ ) such as the Lower Finnis Road Tephra (MacPherson, 1985) or Lower Kakariki Tephra (Bussell, 1984) (Table 2.2). By contrast, Tephra C is characterised by lower concentrations of $\mathrm{FeO}$ (mean $1.08 \%$ ), $\mathrm{CaO}$ (mean 0.87\%), and $\mathrm{K}_{2} \mathrm{O}$ (mean 3.90\%) compared to Tephra B (Fig. 7.4). On plots of major oxides it correlates well with Middle Griffins Road Tephra found in the Rangitikei Valley (cf. Pillans, 1988) (Fig. 7.5). It also correlates with a tephra found in Waipuna Conglomerate (OIS 7) at Landguard Bluff in Wanganui Basin (Sample L185b of Holgate, 1985) (Fig. 7.5).

Unfortunately, no absolute age has been assigned to the Middle Griffins Road Tephra. However, based on its occurrence in Burnand Loess (OIS 8) and Brunswick Dune sand (OIS 7) (Pillans, 1988), Middle Griffins Road Tephra is interpreted to have erupted sometime during around 300ka ago (OIS 9) (Pillans, 1994) (Fig. 7.3). Consequently, although Middle Griffins Road Tephra fell during OIS 9 it was probably reworked extensively during subsequent transgressions into younger deposits (e.g. Holgate, 1985; Pillans, 1988). Therefore, it is possible strata between 206-208m depth represents either OIS 9 if the Middle Griffins Road Tephra is in situ or OIS 7 if it is reworked. A reworked age is favoured here as sample 206-208m depth contains multiple glass shard populations (Fig. 7.4). 

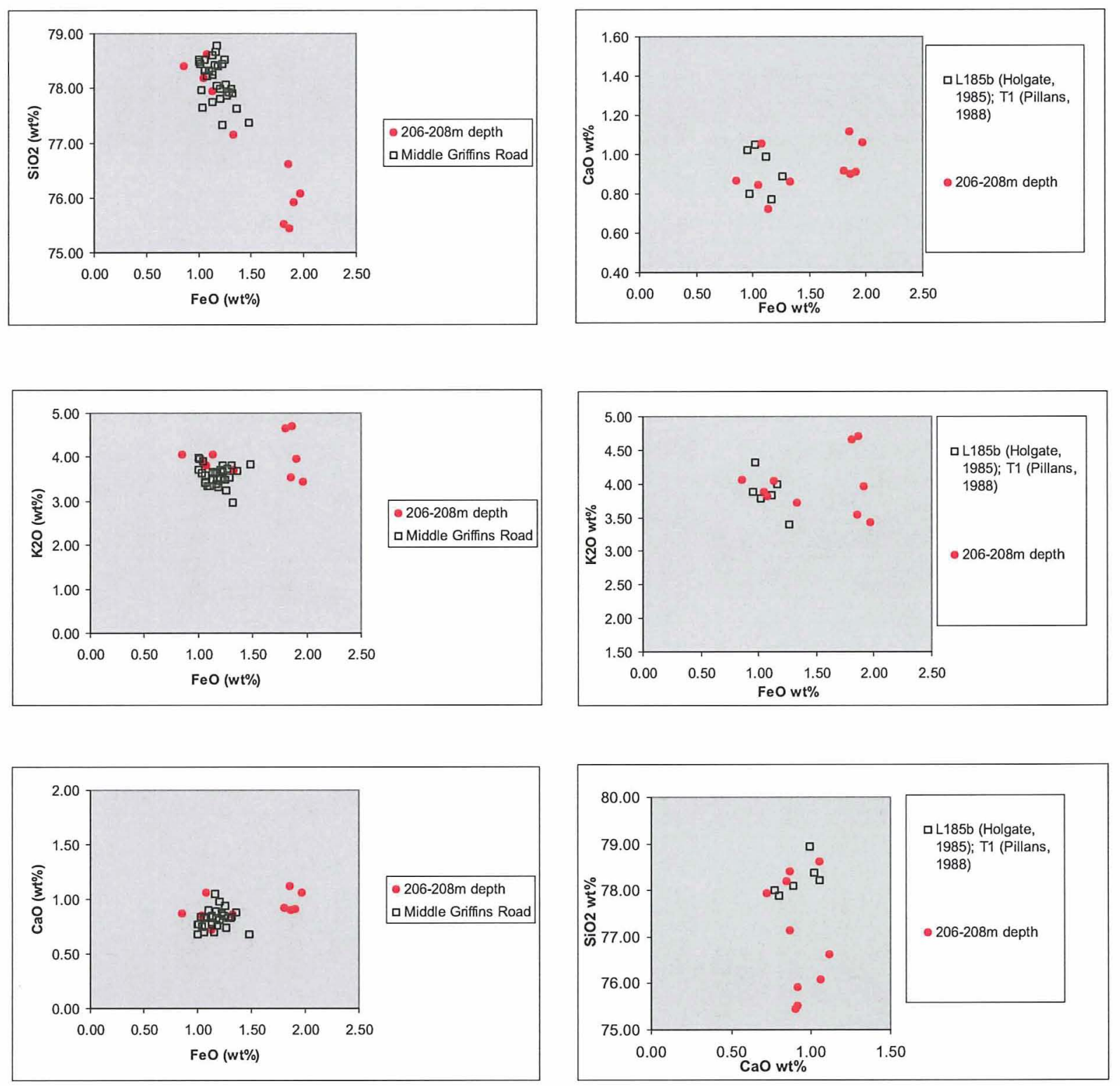

Figure 7.5: Geochemistry of glass shards from sample 206-208m depth. Biaxial plots show good correlation of Tephra C with Middle Griffins Road Ash (left hand side) (data from Pillans pers. comm., 2005). In addition, the samples geochemistry is similar to Sample L185b of Holgate (1985) (right hand side), taken from Waipuna Conglomerate (OIS 7c) at Landguard Bluff, Wanganui Basin. 


\subsubsection{Rangitawa Tephra (Tephra D) and Lower Finnis Road Tephra (Tephra E) (228-229m depth)}

Tephra $\mathbf{D}$ is characterised by low FeO (mean 0.98\%), low $\mathrm{CaO}$ (mean 0.89\%), and high $\mathrm{K}_{2} \mathrm{O}$ (mean $4.11 \%$ ) (Fig. 7.4). It correlates well with Rangitawa Tephra on biaxial plots of major oxide concentrations (Alloway pers. comm., 2005) (Fig. 7.6). Rangitawa Tephra has an isothermal plateau fission track (ITPFT) age of $350 \pm 40 \mathrm{ka}$ ago (Kohn et al., 1992) (Table 2.2). In addition, pollen analysis of strata enclosing Rangitawa Tephra at its type section at Rangitawa Stream indicates it fell during a glacial period (Bussell, 1984), which most likely correlates to OIS 10 (Pillans, 1988) (Fig. 7.3). By contrast, Tephra $\mathbf{E}$ is characterised by high $\mathrm{FeO}$ (mean 1.95\%) and low $\mathrm{K}_{2} \mathrm{O}$ (mean $3.56 \%$ ) compared to Tephra D (Fig. 7.4). A tentative correlation is inferred here with Lower Finnis Road Tephra ( $c f$. MacPherson, 1985) due to a close match between values of $\mathrm{FeO}, \mathrm{CaO}$, and $\mathrm{K}_{2} \mathrm{O}$ (Fig. 7.6). The Lower Finnis Road Tephra has a fission track (FT) zircon age of $320 \pm 70 \mathrm{ka}$ (Seward, 1976) (Fig. 7.3; Table 2.2).

Strata between 228-229m depth most likely deposited sometime during OIS 9 (300$340 \mathrm{ka}$ ) based on the primary occurrence of Rangitawa Tephra (350ka) and less prominent occurrence of Lower Finnis Road Tephra (320ka) in this sample. However, although Rangitawa Tephra fell during OIS 10, it was probably extensively reworked from lowstand deposits during transgressions and incorporated into shallow marine sediment during proceeding interstadial and interglacial periods. Hence, it has been found in Brunswick Terrace (OIS 9), which contains a chemically mixed glass population including Rangitawa Tephra (Pillans, 1988).

\subsubsection{Unknown Tephras F and G (276-277m depth)}

Tephra $\mathbf{F}$ is chemically distinct being characterised by high $\mathrm{FeO}$ (mean 1.97\%), and high $\mathrm{K}_{2} \mathrm{O}$ (mean 4.26\%) (Fig. 7.4). However, this chemistry does not correlate well with any tephras from the Late Pleistocene Wanganui Basin (i.e. Table 2.2). Tephra G is characterised by lower $\mathrm{FeO}$ (mean 1.12\%), $\mathrm{CaO}$ (mean, 0.73\%) and $\mathrm{Na}_{2} \mathrm{O}$ (mean $3.19 \%$ ) than Tephra G (Fig. 7.4), and also cannot be correlated with any known tephras from the Late Pleistocene Wanganui Basin (i.e. Table 2.2). 

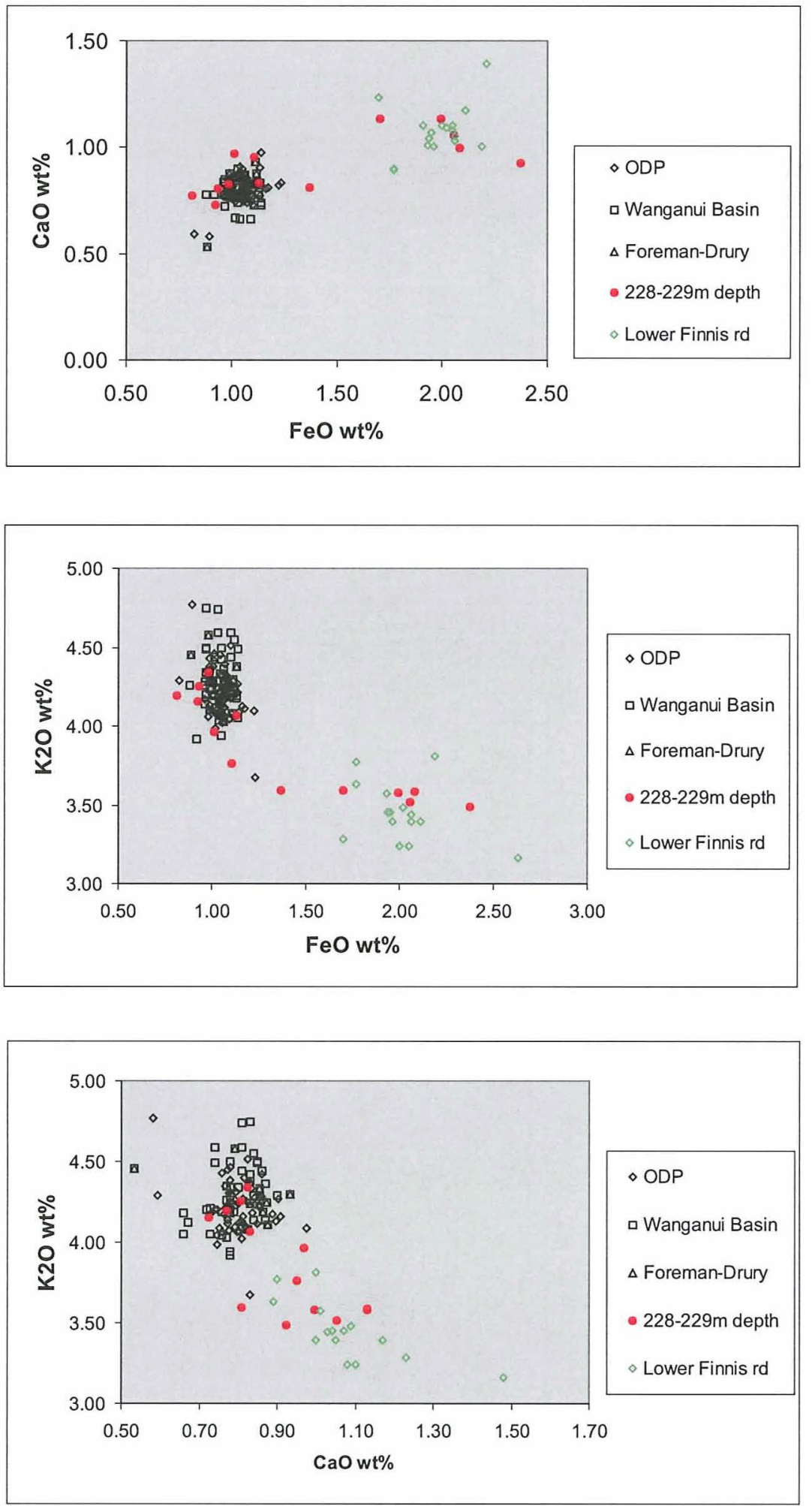

Figure 7.6: Geochemistry of glass shards from sample 228-229m depth.

Biaxial plots show good Correlation of Tephra D with Rangitawa Tephra taken from Ocean Drilling Project (ODP) cores, Wanganui Basin, and Foreman-Drury in Wairarapa (data from Alloway pers. comm., 2005).

The remaining five analyses (= Tephra $\mathrm{E}$ ) have similar geochemistry to

Lower Finnis Road Tephra (MacPherson, 1985). However correlation is not as good between this. 


\subsection{INTEGRATED CHRONOSTRATIGRAPHIC FRAMEWORK}

Based on the recognition of chronologic markers outlined above, the complete Levin borehole sequence is interpreted to span the period between OIS 9 through OIS 2 (34014ka), which equates to the entire Haweran Stage of the Wanganui Series (Fig. 7.7). This age range is based on the recognition of Rangitawa Tephra (340ka) near the base of the sequence in Cycle 1, the overall absence of P. lacunosa, and that the top $40 \mathrm{~m}$ of the borehole comprises fluvial strata deposited during the Last Glacial Period (70-14ka)

\subsubsection{Chronology and periodicity of sedimentary cycles}

A dominant glacioeustatic origin is implied for marine sedimentary cycles located between $265-100 \mathrm{~m}$ depth in the borehole as indicated by pollen data and nannoflora, which show periods of sea level highstand corresponded to peak interglacial or interstadial conditions and periods of sea level lowstand correspond to stadial-glacial conditions (Fig. 7.7). Each cycle potentially represents a complete cycle of sea level change and therefore an interglacial-glacial cycle. However, not all of these stages are represented as some have been replaced by unconformities. For example, cycles 1 and 2 were only deposited during interglacial stages as they contain a TST, HST, RST, but no LST. Conversely, cycles 3 and 4 were deposited during complete interglacial-glacial cycles as they do contain a LST consisting of non-marine gravel deposits.

Strata assigned to Cycle 1 is interpreted to have deposited during the sea level risehighstand period between 300-340ka that is correlative with OIS 9 (Fig. 7.7). This equates to a timeframe of c.40ka for deposition of this cycle. However, the LST of this cycle is missing, which were presumed to have formed during the proceeding glacial lowstand 245-300k ago (OIS 8), but were eroded during a later rise in sea level around $245 \mathrm{ka}$ (OIS 7). Therefore if OIS 8 is included in the timeframe of Cycle 1, a maximum periodicity of c.100ka can be calculated. A periodicity of this magnitude correlates well with Milankovitch orbital eccentricity and supports a Late Pleistocene origin for the cycle (cf. Carter et al., 1991; Carter and Naish, 1998). 
Paleoenvironment

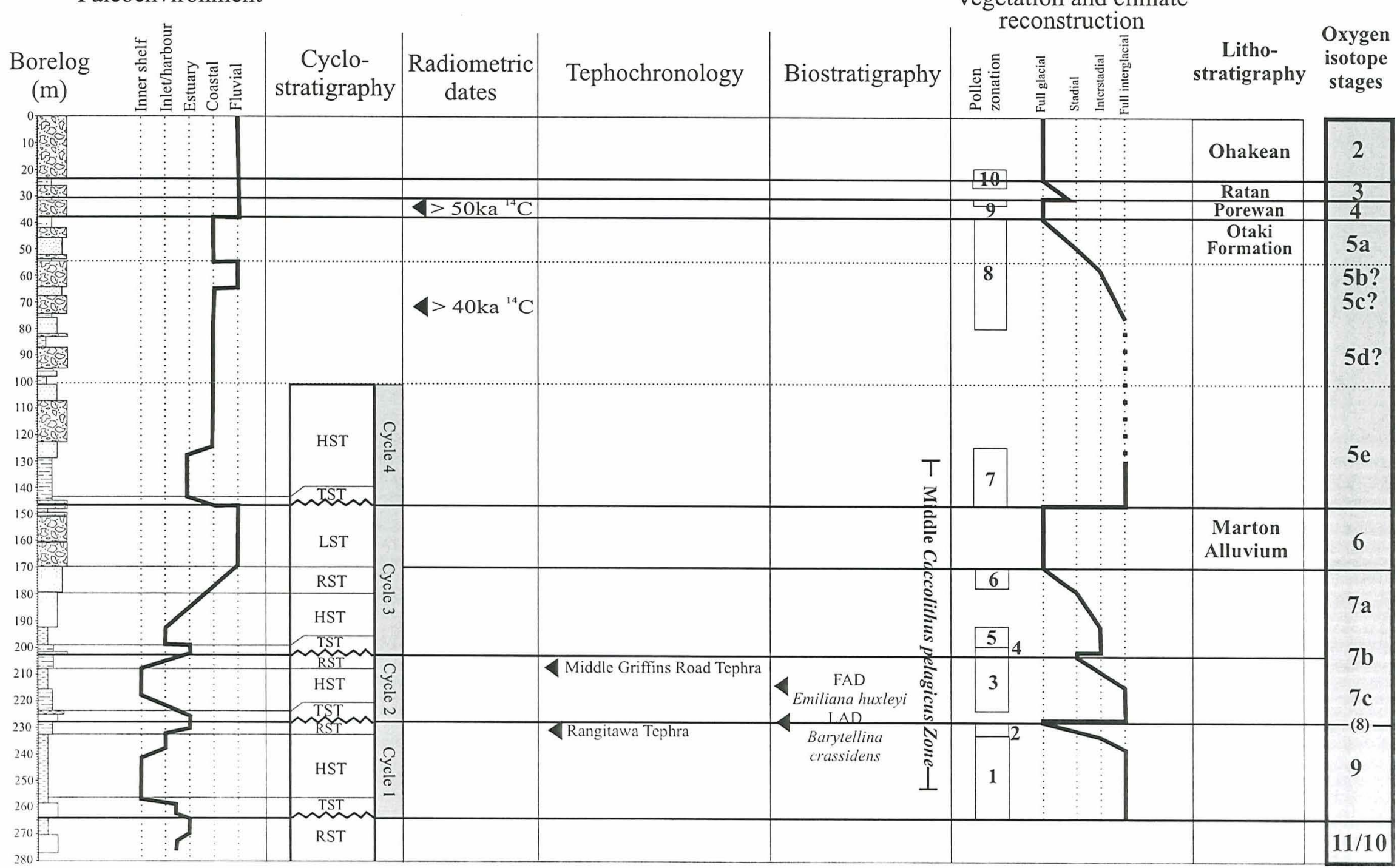

Figure 7.7: Chronostratigraphy of the Levin borehole based on recognition of chronologic markers from the Wanganui Basin $\overline{\bar{N}}$ (after Pillans, 1994) and correlation with marine oxygen isotope stages (Shackleton et al., 1990). 
Cycle 2 and 3 are interpreted to have formed during OIS 7 through 6 (130-245ka). This interpretation is based on the boreholes chronology and pollen record (Fig. 7.7), which suggests two sea level cycles during OIS 7 produced cycle 2 and 3 in the borehole. Oxygen isotope curves suggest OIS 7 was characterised by multiple sea level fluctuations (Imbrie et al., 1984; Williams et al., 1988; Shackleton et al., 1990). Similarly, sea level records typically show two or more closely spaced highstands during OIS 7 separated by a marked sea level fall centred around 230ka ago where a sea level drop of up to $70 \mathrm{~m}$ has been postulated (Chappell and Shackleton, 1986). The stratigraphic record portrayed by cycles 2 and 3 closely reflects two closely spaced highstand that most likely occurred during OIS 7 where cyclostratigraphy shows sea level fell then quickly raised again midway through OIS 7 (Fig. 7.8). In addition pollen data indicates climate deteriorated midway through OIS 7 around $225 \mathrm{ka}$ (i.e. OIS 7b) as indicated by an expansion of beech forest and scrubland vegetation at an expense of conifer broad leaved forests (Fig. 6.4), which may have accompanied the sea level fall (Fig. 6.4). By assigning cycle 2 and 3 in the Levin borehole to the same glacioeustatic cycle a periodicity of $103 \mathrm{ka}$ can be calculated that supports orbital eccentricity as the main forcing mechanism.

Cycle 4 is the youngest sedimentary cycle in the Levin borehole and represents the last extensive marine transgression in the Horowhenua excluding the Post-glacial transgression, which is not recorded in the borehole (see Hesp and Shepherd, 1978). Based on the stratigraphic position and chronology of strata in Cycle 4, it has been correlated with OIS 5e interstadial of the Last Interglacial Period (130-110ka) (Fig. 7.7).

\subsubsection{Chronology of Last Interglacial strata}

Sediment that was deposited during the Last Interglacial Period (130-70ka) has been interpreted to occur between 147-40m depths within the borehole (Fig. 7.7). The lower limit is taken at the base of Cycle 4 (OIS 5e) (see above), above which the siliciclastic strandplain succession represents infilling of the marine embayment under highstand conditions ( $c f$. Dominguez et al., 1987). The top $15 \mathrm{~m}$ of this succession is correlative with the Otaki Formation (OIS 5c-5a; Sewell, 1991) (Fig. 7.1). However, the exact location of oxygen isotope sub-stages $5 \mathrm{a}, 5 \mathrm{~b}, 5 \mathrm{c}$, and $5 \mathrm{~d}$ cannot be distinguished in the 
borehole due to large gaps in the fossil record (Fig. 7.7), and the fact that the top part of the Otaki Formation has been truncated by Last Glacial gravel strata.

\subsubsection{Chronology of Last Glacial strata}

Sediment that was deposited during the Last Glacial Period (14-71ka) is interpreted to occupy the top $40 \mathrm{~m}$ of the borehole (i.e. Fig. 7.1). The stratum is essentially cyclic where periods of rapid fluvial deposition were followed by periods of fine-grained silt deposition. Approximately three gravel-silt couplets are represented by the strata that can be correlated with the Porewan (OIS 4; 59-71ka), Ratan (OIS 3; 24-59ka), and Ohakean (OIS 2; 14-24ka) sub-stages based on pollen data (Fig. 7.7).

\subsection{CHRONOLOGY AND UPLIFT OF THE LEVIN FAULT}

An age and uplift rate for the Levin Fault is estimated using a seismic reflection profile created by Aharoni (1991) less than 3km south of the drill site near Ohau and chronostratigraphic surfaces in the Levin borehole (Fig. 7.9). Three reflectors from the profile (1B, 1A, and 1AA) intersect the borehole at c. $260 \mathrm{~m}, \mathrm{c.} .120 \mathrm{~m}$, and c. $40 \mathrm{~m}$ depths corresponding closely with the base of the base of Cycle 1 (thick mud, litho-unit 4), the change from marine to coastal plain strata (approximate base of Last Interglacial strata), and the change from coastal plain to fluvial strata (base of Last Glacial strata). Although the latter gravel strata is confined to hollows incised into the Tokomaru Marine Terrace during the Last Glacial Period (i.e. Fig. 7.1), and may not be as laterally extensive as figure 7.9 illustrates.

A minimum age of the Levin Fault is estimated at around $80-120 \mathrm{ka}$ ago based on the offset of seismic reflector 1A (base of Last Interglacial strata), but no offset of Last Glacial fluvial strata (i.e. Fig. 7.1). An uplift rate of c. $0.7 \mathrm{~mm} / \mathrm{yr}^{-1}$ is calculated for the fault based on an age of c.340ka for reflector 1B (base of Cycle 1) that has been offset by $240 \mathrm{~m}$ relative to reflector 3B (Fig. 7.9). This value corresponds approximately with a previous estimate of $0.5 \mathrm{~mm} / \mathrm{yr}^{-1}$, based on a broader mid-Pleistocene age for the same reflector determined from offshore well correlations (Aharoni, 1991). 


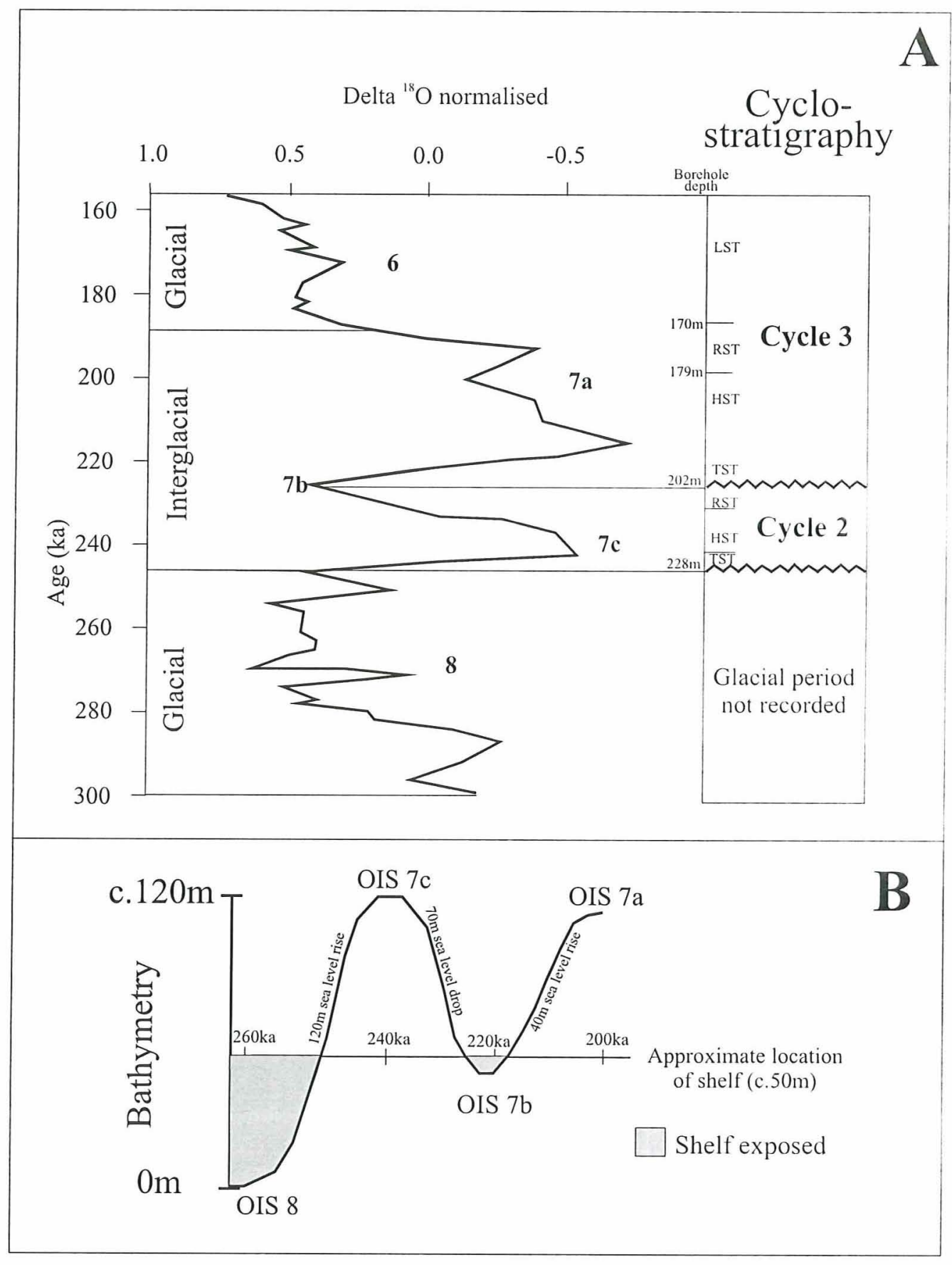

Figure 7.8: A. Correlation of Cycles 2 and 3 with deep sea oxygen isotope record (after Imbrie et al., 1984).

B. Diagram showing how bathymetry may have changed in the Levin area during OIS 7. 


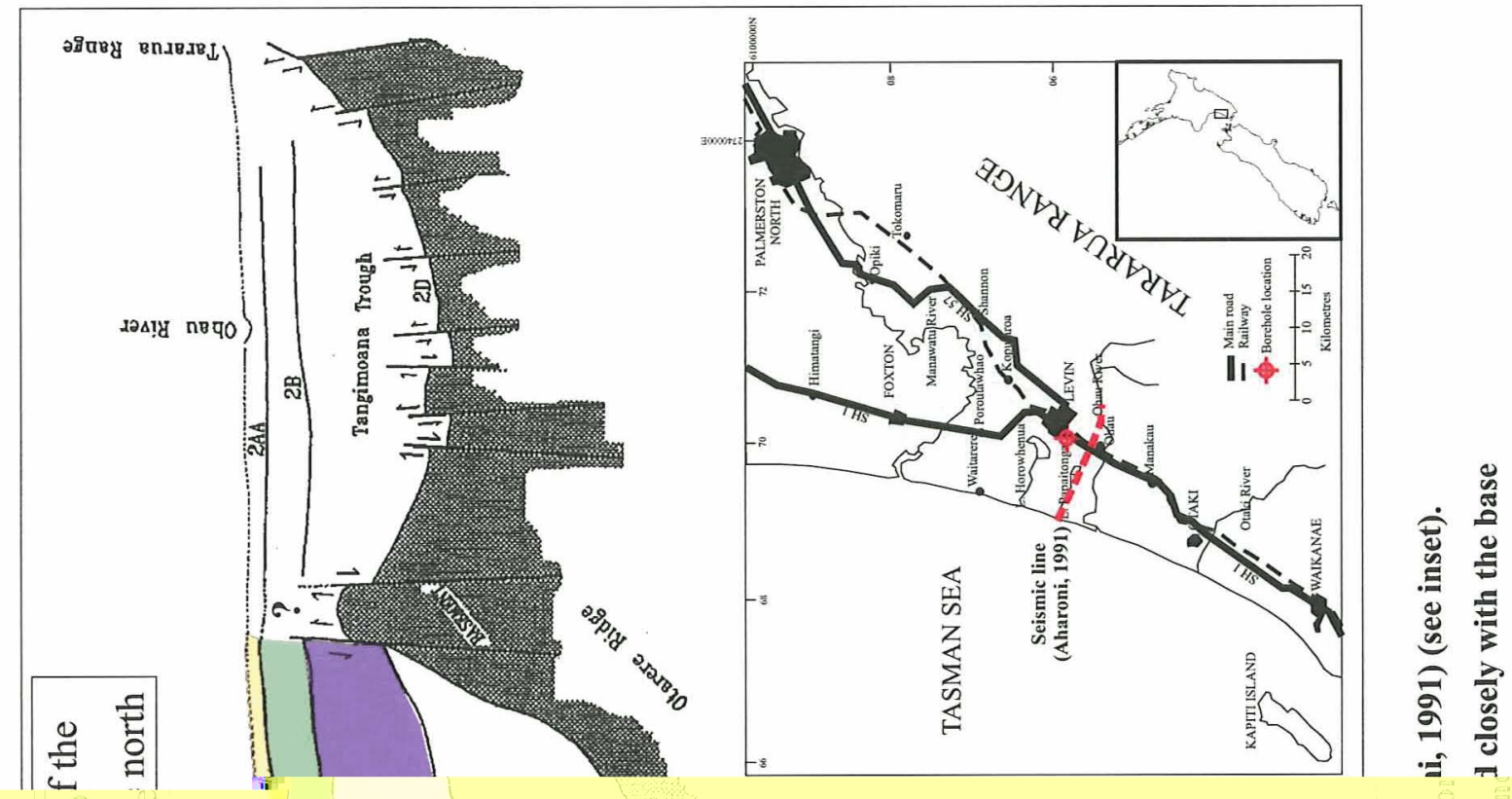




\subsection{SUMMARY OF BOREHOLE CHRONOLOGY}

In summary, the four sedimentary cycles represented by cyclical marine strata between 264-100m depths in the borehole were deposited during transgressions and regressions between 340ka-120ka (OIS 9-5e). The cycles have a periodicity of c.100ka, which

indicates a dominant $5^{\text {th }}$ order glacioeustatic origin. The siliciclastic strandplain succession represented between 100-40m depths in the borehole was deposited during the middle to later part of the Last Interglacial Period between 120-70ka (OIS 5d-5a) and developed from infilling of a marine embayment, which developed during transgression at the beginning of OIS 5e. The uppermost $40 \mathrm{~m}$ of the borehole represents an old floodplain of the Ohau River whose deposits are correlative with the Porewan, Ratan, and Ohakean aggradation periods that occurred during the Last Glacial Period (i.e. OIS 4, 3, and 2 respectively). 


\section{CHAPTER 8}

\section{CONCLUSIONS AND PALEOENVIRONMENTAL SYNTHESIS OF THE LEVIN BOREHOLE}

\subsection{INTRODUCTION}

The Levin borehole intersected c.280m of relatively unconsolidated strata in the north Horowhenua District and contains a near continuous sedimentary record for the latest Pleistocene (last 340ka). Thirty six lithological units characterise the borehole ranging from mud, silt, and sand to coarse-grained gravel deposits, which represent a broad coarsening-, shallowing-upward succession. Facies analysis indicates litho-units 1-21 in the lower $160 \mathrm{~m}$ of the borehole, which consist of mud, silt and sand deposits, were deposited in a range of shallow marine to paralic environments. The middle part of the borehole, between $100-40 \mathrm{~m}$ depth containing litho-units $22-31$, is interpreted as representing coastal sand and fluvial gravel sediments that were deposited in a coastal plain environment. Strata from the top $40 \mathrm{~m}$ of the borehole, containing litho-units 32 36 , consists of thick terrestrial gravel and thin silt deposits assigned to fluvial channel and back-swamp floodplain facies.

Four sedimentary cycles have been recognised in the marine litho-units between 265$100 \mathrm{~m}$ depths. The cycles represent progressive infilling of the Kairanga Trough during $5^{\text {th }}$ order (c.100ka) glacio-eustatic fluctuations between oxygen isotope stages 9 and $5 \mathrm{e}$. Paralic and fluvial strata between $100-40 \mathrm{~m}$ depths represent a siliciclastic strandplain succession that formed as a result of coastal progradation during the Last Interglacial Period (120-70ka). The fluvial sediment in the top 40m of the borehole are the result of aggradation during Last Glacial Period (70-14ka), where three thick gravel units in this sequence correlate to the Porewan (OIS 4), Ratan (OIS 3), and Ohakean (OIS 2) substages respectively.

\subsection{GEOLOGICAL SYNTHESIS OF THE LEVIN BOREHOLE}

(Refer to sequence of Figs. 8.1) 
Figure 8.1: Sequence of diagrams illustrating the inferred pelenvironmental changes that accompanied deposition of the Levin borehole (refer to text).
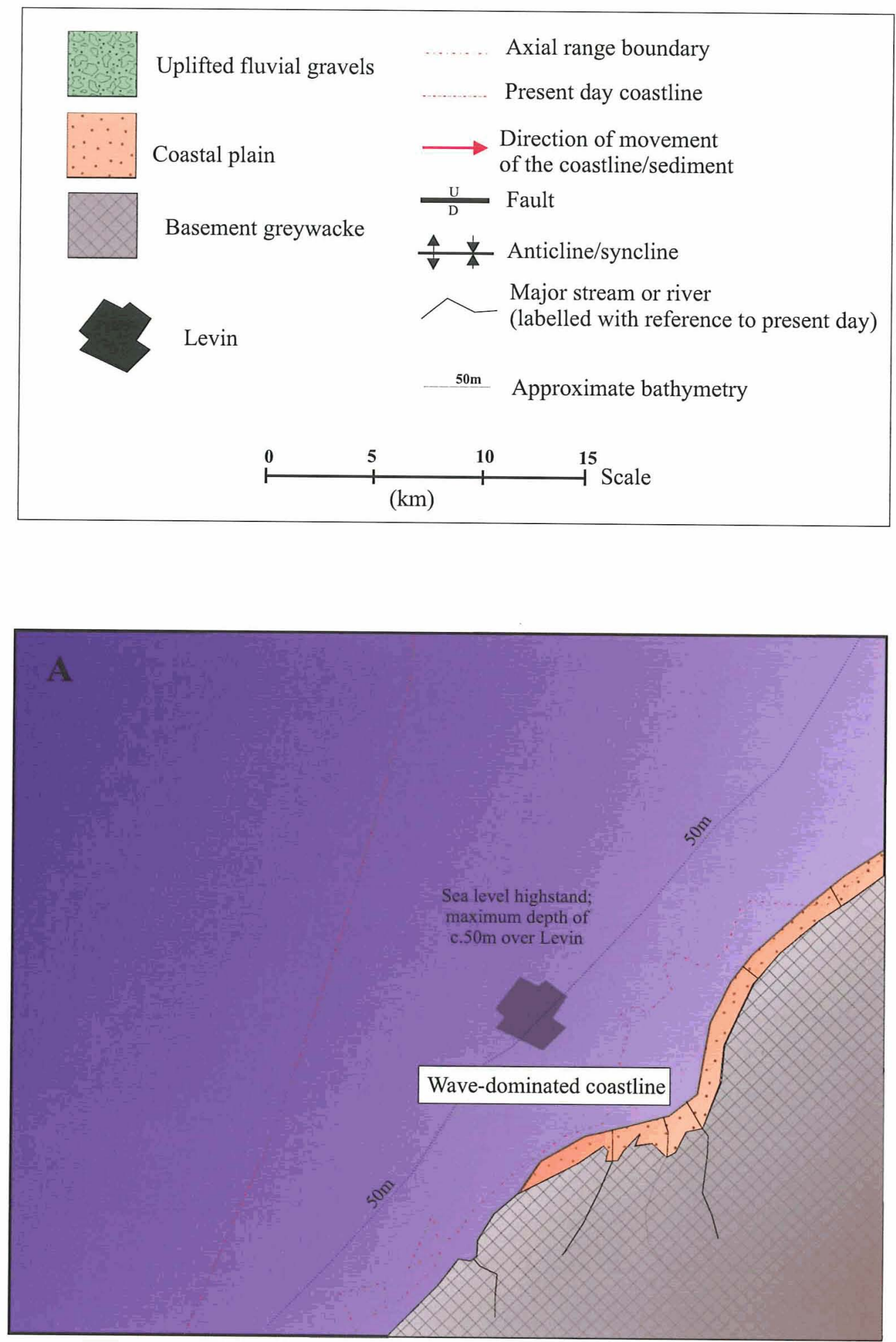


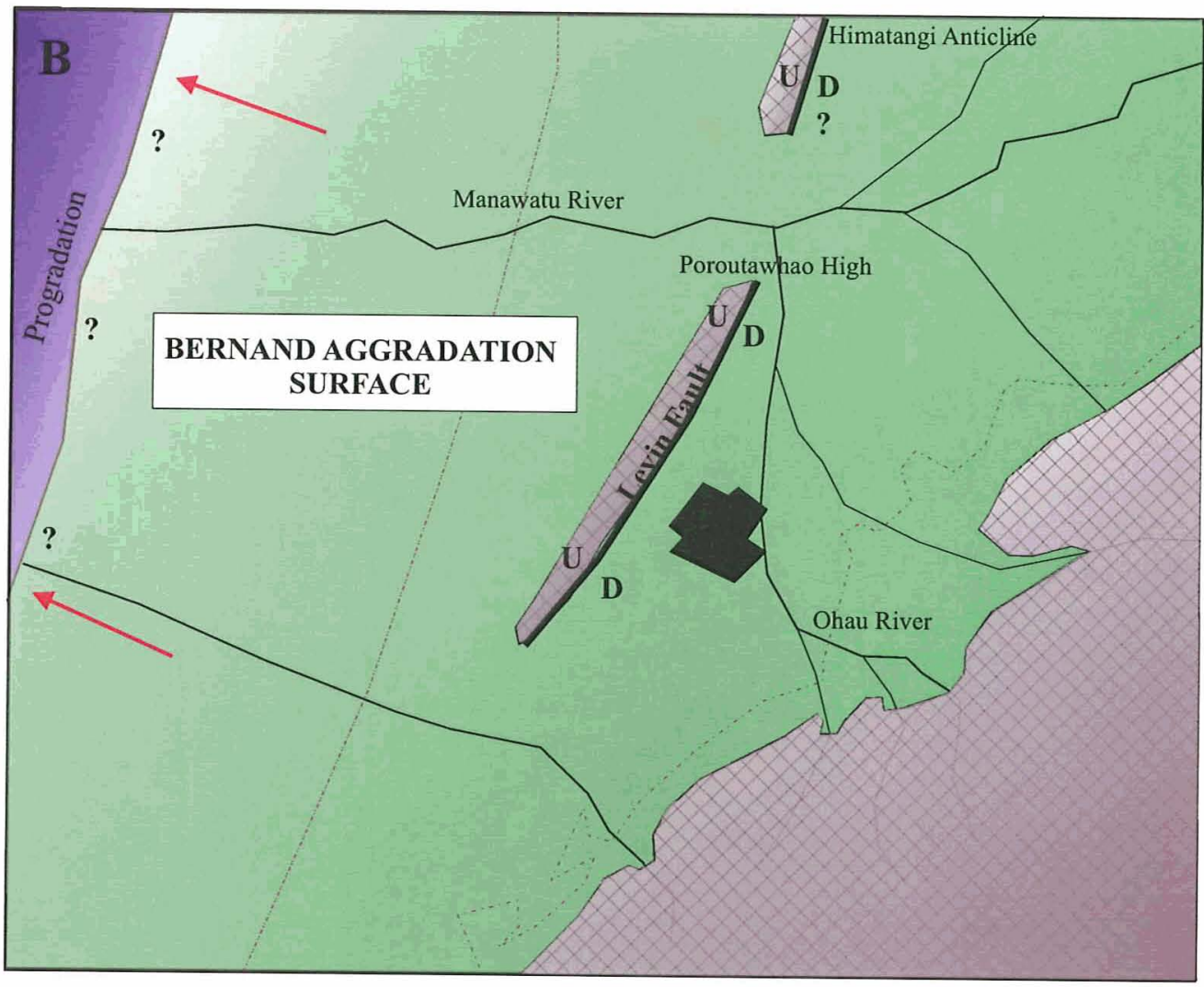

(m)

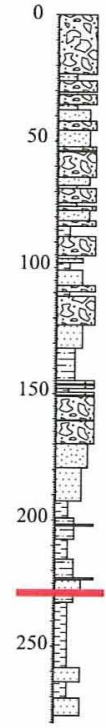

c.300ka (OIS 8) LOWSTAND

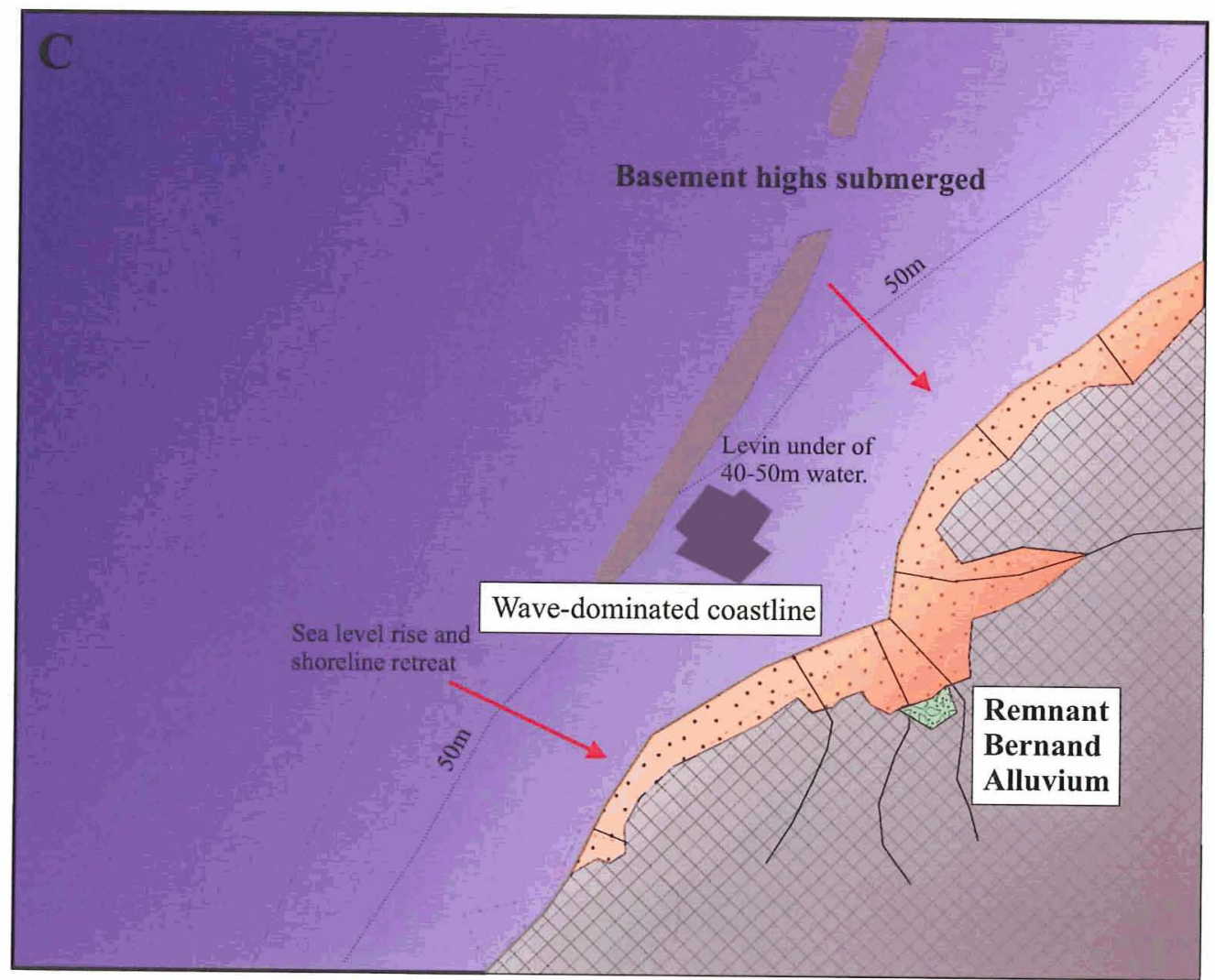

(m)

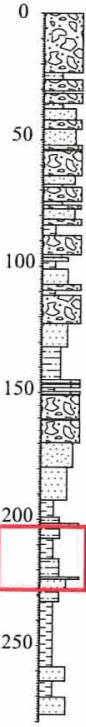

Fig. 8.1: continued..

C.245ka (OIS 7c) HIGHSTAND 

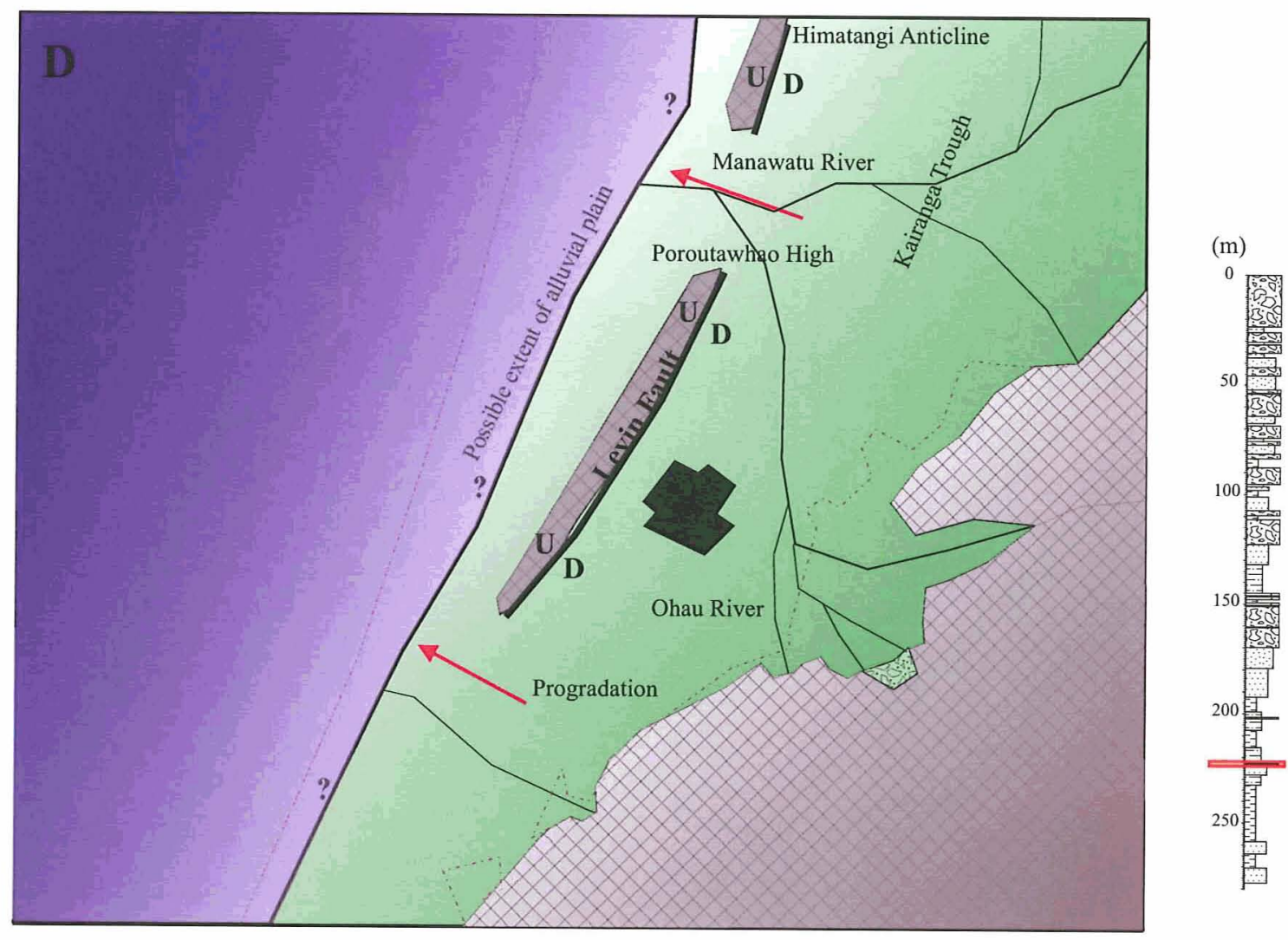

C.225ka (OIS 7b) STADIAL
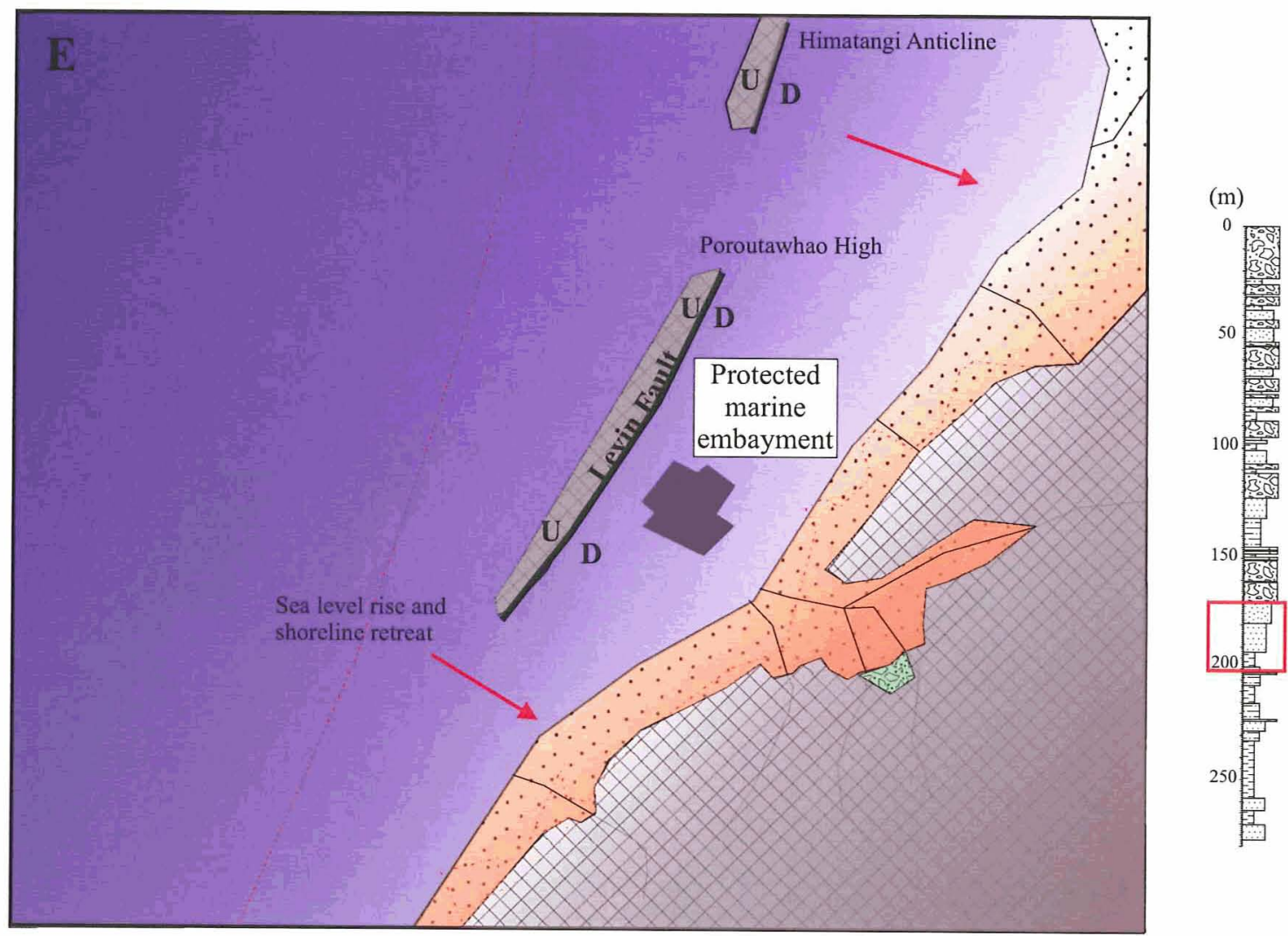

Fig. 8.1: continued... 

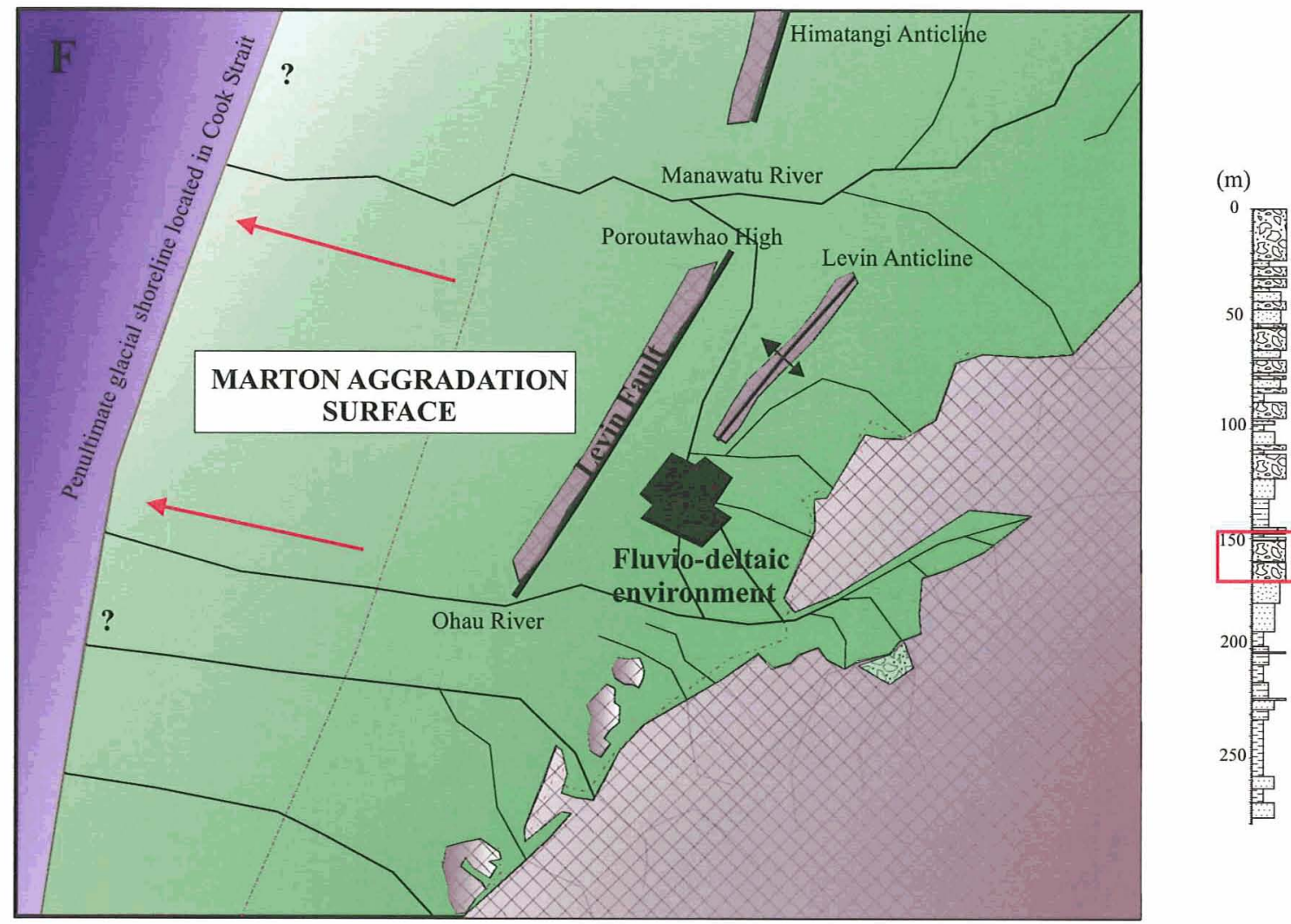

C.186ka (OIS 6) LOWSTAND

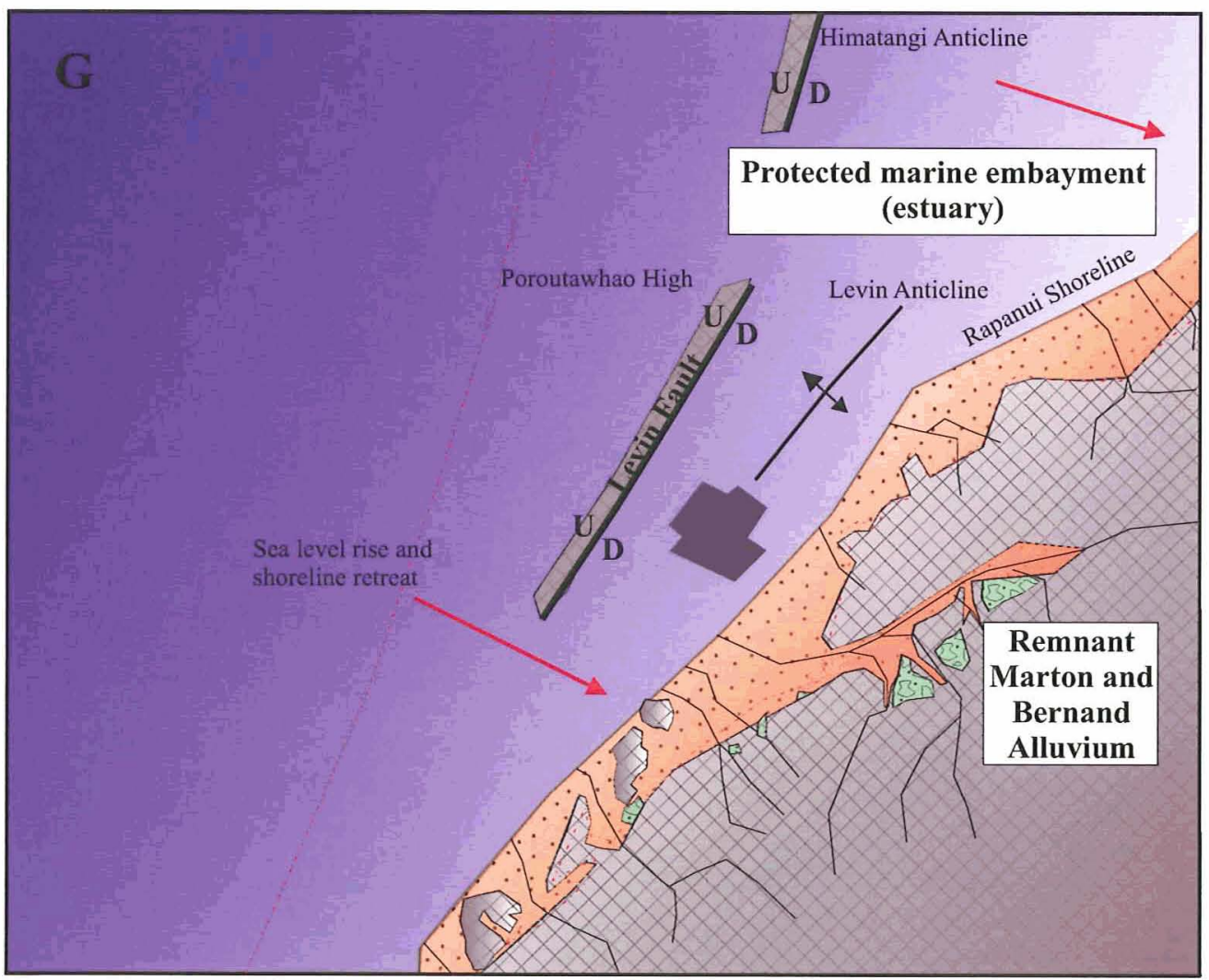

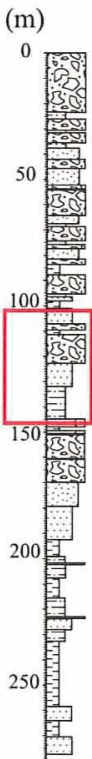

Fig. 8.1: continued.... 


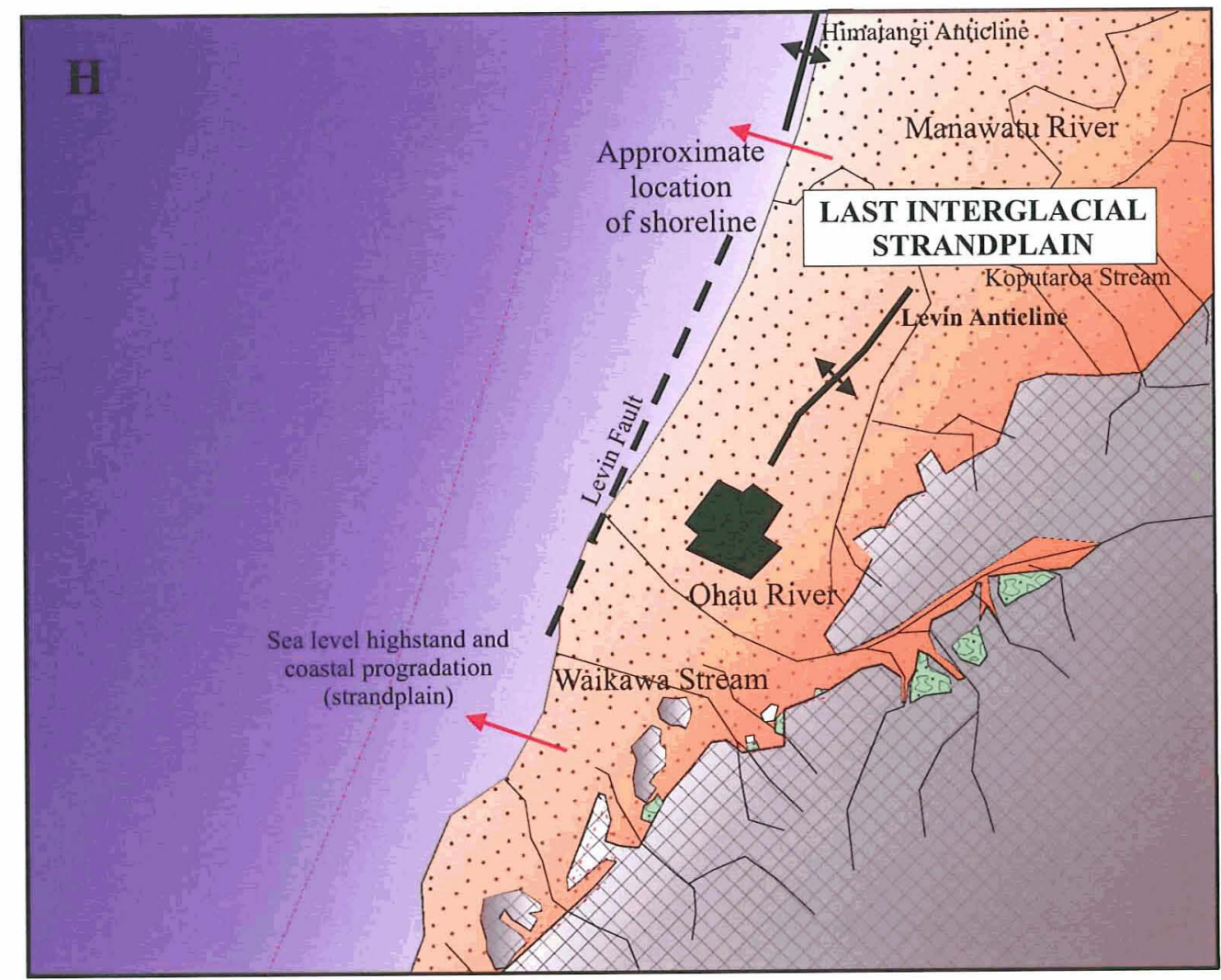

c.110-70ka (OIS 5d-5a) INTERGLACIAL/HIGHSTAND

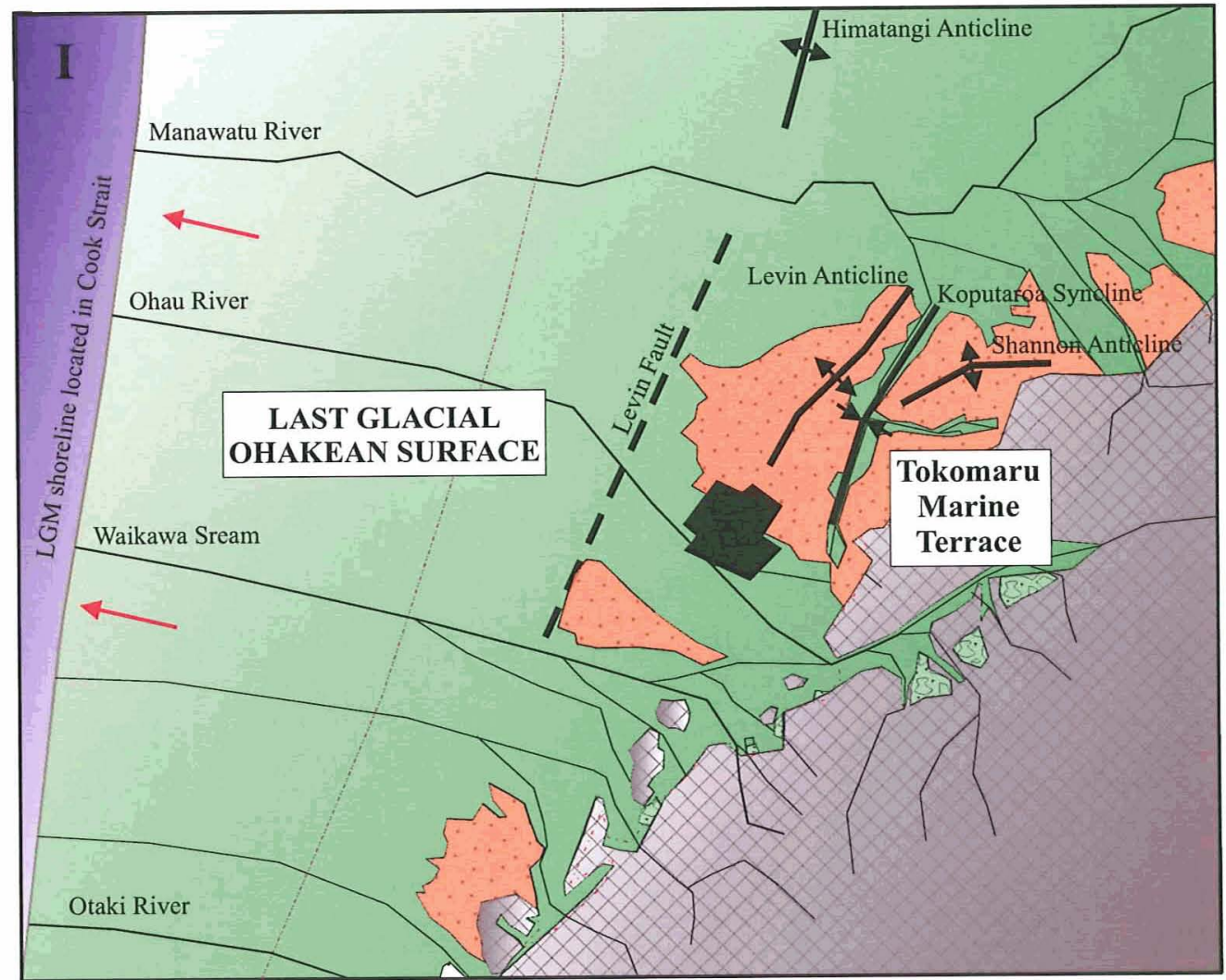

(m)

Fig. 8.1: continued..... 
About 340ka ago (OIS 9) the Horowhenua District was underwater, part a wavedominated shelf environment at a water depth of about 50m (Fig. 8.1A). This interpretation is based on sediment characteristics of litho-unit 4 (HST of Cycle 1) and that it contains deep water foraminifera (Fig. 4.4). The shelf may have had a similar gradient to present and the axial range were about $450 \mathrm{~m}$ lower, based on an average uplift rate of $1.3 \mathrm{~mm} / \mathrm{yr}^{-1}$ (i.e. Ghani, 1978), placing the coastline c. $10 \mathrm{~km}$ inland from the drill site (Fig. 8.1A). Sea level remained at this highstand position for about 30ka. A shoreface sediment wedge prograded from the coastline as a result of an abundant supply of sediment, which is recorded between $232-228 \mathrm{~m}$ depths in the borehole where shoreface sediment (litho-unit 5) overlies shelf mud deposits (Fig. 5.3).

As sea level fell associated with climate cooling around 300ka ago (OIS 8), the broad low-lying Horowhenua shelf was exposed and the shoreline most likely shifted to a location to the west in Cook Strait (Fig. 8.1B). A lack of sediment record at this time means there is no certainty whether aggradation or incision occurred. The low amount of terrigenous material in the Levin borehole between 230-225m depths may imply the Ohau River and Koputaroa Stream were deflected further north than their present paths by exposed basement highs (i.e. Poroutawhao High) forming tributaries to the Manawatu River in the Kairanga Trough. As a result the north Horowhenua shelf may have been starved of sediment causing non-deposition. However, it is more likely rivers aggraded their beds in response to a forced regression (i.e. Browne and Naish, 2003) as remnants of expansive gravel surfaces can still be found abutting the sides of the Tararua Range, which now tilt westward as a result of tectonic uplift and are covered by up to four loess units (Barnett, 1984; Palmer et al., 1988) (Fig. 8.1B). These surfaces are correlative with the Burnand Surface in the Rangitikei Valley (OIS 8) (Milne, 1973).

The Burnand Alluvium was subsequently eroded when sea level rose around $245 \mathrm{ka}$ ago and the shoreface transgressed over the north Horowhenua shelf producing an unconformity recorded between the RST of Cycle 1 and TST of Cycle 2 in the borehole (Fig. 5.3). As a highstand was reached, sediment characteristics and foraminifera contained in litho-unit 9 (HST of Cycle 2) indicate a wave-dominated coastline redeveloped in the north Horowhenua that was under $40-50 \mathrm{~m}$ of water, which chronological and pollen data has correlated to OIS 7c interstadial (Fig. 8.1C). The 
highstand was terminated by a sea level fall of about $70 \mathrm{~m}$ around $225 \mathrm{ka}$ ago exposing the north Horowhenua shelf (Fig. 8.1D). Pollen contained in borehole strata between 205-195m depths shows a change from conifer broad leaved forest to beech forest and scrubland vegetation accompanied the fall in sea level correlating it to OIS 7b stadial period. Following the stadial, about 200ka ago, sea level quickly rose by about $50 \mathrm{~m}$ resulting in deposition of litho-unit 13 in a tidal marine embayment as it contains brackish water foraminifera (Fig. 8.1E). Palynology of strata in litho-unit 13 correlates the later highstand with OIS 7a (Fig. 7.7). The marine embayment may have sheltered behind the Poroutawhao High reducing the impact of wave energy in the north Horowhenua (Fig. 8.1E). Rapid infilling of the marine embayment occurred during the latter stages of the highstand around 190ka ago, which formed a conformable sequence of estuarine and fluvial strata in the borehole between 180-160m depths (i.e. RST of Cycle 3).

OIS 6 (186ka ago) was characterised by climate cooling and sea level lowering. Consequently, the Horowhenua coastline became strongly progradational resulting in extensive fluvial aggradation and deposition of litho-unit 16 (Fig. 8.1F). A large increase in terrigenous sediment in the borehole between 170-147m depths suggests a strong influence of the Ohau River, which may have been forced to drain into a localised depression near Levin by the Levin Anticline (depicted in Fig. 8.1F). The lowstand gravels (litho-unit 16) are correlative with Marton Alluvium in Rangitikei Valley (OIS 6) (Milne, 1973), of which only small patches are preserved as uplifted loess covered terraces abutting the Tararua Range (Barnett, 1984; Palmer et al., 1988) (Fig. 2.4).

World wide climate warming around 130ka ago (OIS 5e) produced a transgression that cut a sea cliff inland near Shannon, which truncates both Marton Alluvium and basement greywacke comprising the Tararua Range (Palmer et al., 1988) (Fig. 8.1G). The sea cliff represents the maximum extent of the transgression and has been correlated with the Last Interglacial 'Rapanui' strandline in Wanganui Basin (Palmer et al., 1988). Sediment characteristics and foraminifera contained in borehole strata between 146-130m depths (litho-unit 18) indicate an estuary developed in the north Horowhenua following the transgression, which occupied a broad valley incised into the 
Marton Surface (OIS 6) (Fig. 8.1G). The estuarine embayment was quite extensive and extended from the Horowhenua to the north Manawatu (Fig. 8.1G). The lateral extent is indicated by the presence of estuarine dwelling molluscs in a well at Awahuri around $70 \mathrm{~m}$ below sea level, which were dated at $>45 \mathrm{ka}$ BP and correlated to the Last Interglacial Period using biostratigraphy (Te Punga, 1954b) (App. F). The estuary may have sheltered behind the Poroutawhao High and the Himatangi Anticline, which are thought to have been exposed above sea level during the Last Interglacial Period (Rich, 1959; Sewell, 1991) (Fig. 8.1G). Evidence for the existence of these barriers to the west comes from sedimentological analysis of the Otaki Formation, which indicates an influence of mixed tide and wave processes in the north Horowhenua (Sewell, 1991). Outlets to the sea probably occurred between the two basement highs near the mouth of the Manawatu River and south of Ohau where gravity data shows a decrease in elevation of the Poroutawhao High (Bekesi, 1989) (Fig. 8.1G).

During the middle to later stages of the Last Interglacial highstand, a strandplain developed from infilling of the estuary with an abundant supply of coastal and terrigenous sediment. The thick and relatively conformable sequence of beach sand, fluvial gravels, then dune sand between 120-100m depths in the Levin borehole are the result of the infilling (i.e. HST of Cycle 4). The gravel and sand deposits are laterally extensive within boreholes drilled in the Horowhenua (Fig. 7.1) and on seismic reflection profiles (e.g. Aharoni) (Fig. 7.9) suggesting the strandplain was a prominent and relatively flat, low-lying coastal feature (depicted in Fig. 8.1H). The Otaki Formation, which composes the Tokomaru Marine Terrace, correlates to the top $15 \mathrm{~m}$ of the strandplain succession in the borehole (litho-units 29-27). This thickness is a minimum estimate as the top c.30m of the Otaki Formation has been truncated by Last Glacial gravel strata (Figs. 3.7 and 7.1). Regional geomorphic studies suggests uplift was occurring contemporaneously with formation of the Otaki Formation as the Tokomaru Marine Terrace is warped along pre-existing basement thrust faults that occur beneath Levin and Shannon (Te Punga, 1957; Hesp, 1975) (Fig. 8.1H).

Lowering of sea level of up to $120 \mathrm{~m}$ around $70 \mathrm{ka}$ ago (Fairbanks, 1989) resulted in large areas of the coastal marine terrace being removed and/or buried by aggrading rivers. This left remnants of the Tokomaru Marine Terrace exposed up to $50 \mathrm{~m}$ above 
sea level (Hesp and Shepherd, 1978) while other hollows in-filled with fluvial gravels (Fig. 8.1G). The top $40 \mathrm{~m}$ of the borehole contains fluvial channel and floodplain deposits that accumulated in a depression incised into the Tokomaru Marine Terrace by the Ohau River during the Last Glacial Period (Fig. 7.1). This fluvial sequence is suggested to have developed from three episodes of fluvial aggradation during OIS 2, 3 , and 4 respectively (Fig. 7.7). The Poroutawhao High may not have affected sedimentation of gravel strata during the Last Glacial Period and the Ohau River probably took a direct drainage route out to sea (Fig. 8.1I). Evident for this is that the Ohakean Surface can be seen thinning from a maximum thickness of $70 \mathrm{~m}$ near the Tararua Range to around 40m near Levin to less than 20m near Hokio Beach (Fig. 7.1). If the Poroutawhao High was exposed, one would expect a westward thickening trend as sediment would have piled up against the eastern side of Levin Fault. It is postulated that the Poroutawhao High was no longer uplifting subsequent to the Last Interglacial Period as any Last Glacial strata is observed to have been faulted (Figs. 7.1 and 7.9). Final truncation of the Tokomaru Marine Terrace and fluvial aggradation surfaces occurred during the post glacial transgression (7-14ka) (Hesp and Shepherd, 1987).

\subsection{CONCLUDING COMMENTS}

The Levin borehole accurately records environmental change in the north Horowhenua District for the past 340ka (Late Pleistocene). Sedimentation has been predominantly controlled by climate and glacioeustatic fluctuations driven by orbital eccentricity and Late Pleistocene glaciations, which have a periodicity of about 100ka. Superimposed on these cycles has been the affects of an abundant sediment supply and local folding and faulting of basement geology, which characterise the Horowhenua District. 


\section{REFERENCES}

Abbott, S. T. 1997. Mid-cycle condensed shell beds from mid-Pleistocene cyclothems, New Zealand: implications for sequence architecture. Sedimentology 44: 805-824.

Abbott, S. T. 1998. Transgressive Systems Tracts and Onlap Shellbeds from MidPleistocene Sequences, Wanganui Basin, New Zealand. Journal of Sedimentary Research 68 (2): 253-268.

Abbott, S. T. \& Carter, R. M. 1994. The sequence architecture of mid-Pleistocene (c. 1.1-0.4 Ma) cyclothems from New Zealand: facies development during a period of orbital control on sea-level cyclicity. In De Boer, P. L. and Smith, D. G. (Eds.), Orbital Forcing and Cyclic Sequences. Special Publication of the International Association of Sedimentologists 19: 367-394.

Adkin, G. L. 1910. The post-tertiary geological history of the Ohau River and the adjacent coastal plain, Horowhenua Country, North Island. Transactions of the New Zealand Institute XLIII 496-520.

Aharoni, E. 1991. Seismic reflection study across the Horowhenua coastal plain, North Island, New Zealand. Unpublished MSc Thesis, Victoria University of Wellington.

Alloway, B. V., Pillans, B., Sandhu, A. S., Westgate, J. S. 1993. Revision of the marine chronology of the Wanganui Basin based on isotherm plateau fission-track dating of tephra horizons. Sedimentary Geology 81: 299-310.

Anderton, P. W. 1981. Structure and evolution of the South Wanganui Basin, New Zealand. New Zealand Journal of Geology and Geophysics 24: 39-63.

Armour, R. 2003. A record of late Holocene vegetation change from Whanganui Inlet and Mangarakau Swamp, NW Nelson. Unpublished MSc Thesis, Victoria University of Wellington. 
Barnett, R. 1994. Upper Quaternary stratigraphy in the Otaki District. Unpublished BSc hons. Thesis. Victoria University of Wellington.

Barrett, P. J., Brooker, M. K., Anderson, J. J. 2000. Grainsize analysis at VUW. Victoria University of Wellington, Wellington.

Begg, J. G. and Johnston, M. R. 2000. Geology of the Wellington Area. Includes 1 : 250, 000 geological map 10. Institute of Geological and Nuclear Sciences, Lower Hutt, New Zealand.

Bennett, K. D. 1998. Documentation Psimpoll 3.10 and Pscomb 1.03. Uppsala Universitet, Sweden.

Bekesi, G. 1989. Geophysical Studies over the North Horowhenua Sedimentary Basin. Unpublished MSc Thesis, Victoria University of Wellington.

Beu, A. G. and Edwards, A. R. 1984. New Zealand Pleistocene and late Pliocene glacioeustatic cycles. Palaeogeography, Palaeoclimatology, Palaeoecology 46: 119142.

Beu, A. G. and Maxwell, P. A. 1990. Cenozoic Molluscs of New Zealand. New Zealand Geological Survey Paleontological Bulletin 58.

Birks, H. J. B. and Birks, H. H. 1980. Quaternary Paleoecology. Edward Arnold Limited, London.

Blair, T. C. and McPherson, J. G. 1994. Alluvial fans and their natural distinction from rivers based on morphology, hydraulic processes, sedimentary processes, and facies assemblages. Journal of Sedimentary Research A64 (3) 450-489.

Blum, M. D. and Price, D. M. 1998. Quaternary alluvial plain construction in response to glacio-eustatic and climate controls, Texas Gulf coastal plain. In Shanley, K. W. 
and McCabe, P. J. (eds.), Relative Role of Eustacy, Climate, and Tectonism in Continental Rocks. SEPM Special Publication 59: 31-48.

Boggs, S. 1995. Principles of Sedimentology and Stratigraphy (second edition). Prentice-Hall Inc. New Jersey.

Boyd. R., Dalrymple, R., Zaitlin, B. A. 1992. Classification of clastic coastal depositional environments. Sedimentary Geology 80: 139-150.

Brown, L. 2003. Te Horo beach groundwater investigation bores. Resource Investigations Great Wellington - The Regional Council Report April 2003.

Browne, G. H. \& Naish, T. R. 2003. Facies development and sequence architecture of a late Quaternary fluvial-marine transition, Canterbury Plains and shelf, New Zealand: implications for forced regressive deposits. Sedimentary Geology 158: 57-86.

Bryant, V. M., Holloway, R. G., Jones, J. G., Carlson, D. L. 1994. Pollen preservation in alkaline soils of the American Southwest. In Traverse, A. (ed.). Sedimentation of Organic Particles. Cambridge University Press pp. 47-58.

Bussell, M. R. 1984. Geology and paleobotany of the Rangitawa Stream area, southeast Wanganui Basin. Unpublished BSc hons. Thesis. Victoria University of Wellington.

Bussell, M. R. 1986. Palynological evidence for upper Putikian (middle Pleistocene) interglacial and glacial climates at Rangitawa Stream, South Wanganui Basin, New Zealand. New Zealand Journal of Geology and Geophysics 29: 471-479.

Bussell, M. R. 1990. Palynology of Oxygen isotope stage 6 and substage 5e from the cover beds of a marine terrace, Taranaki, New Zealand. Quaternary Research 34: 86-100. 
Bussell, M. R. 1993. A late Pleistocene vegetational and climatic history of part oxygen isotope stage 5, Ararata, south Taranaki, New Zealand. Journal of the Royal Society of New Zealand 23: 125-145.

Bussell, M. R. and Mildenhall, D. S. 1990. Extinct palynomorphs from middle to late Pleistocene terrestrial sediment, South Wanganui Basin, New Zealand. New Zealand Journal of Geology and Geophysics 33: 439-447.

Bussell, M. R. and Pillans, B. 1997. Vegetational and climatic history during oxygen isotope stage 7 and early stage 6, Taranaki, New Zealand. Journal of the Royal Society of New Zealand 27 (4): 419-438.

Carter, R. M. and Naish, T. R. 1998. A Review of Wanganui Basin, New Zealand: global reference section for shallow marine, Plio-Pleistocene (2.5-0Ma) Cyclostratigraphy. Sedimentary Geology 122: 37-52.

Carter, R. M., Abbott, S. T., Fulthorpe, C. S., Haywick, D. W., Henderson, R. A. 1991. Application of global sea-level and sequence-stratigraphy models in Southern Hemisphere Neogene strata from New Zealand. Special Publication of the International Association of Sedimentologists 12: 41-65.

Chappell, J. and Shackleton, N. J. 1986. Oxygen isotopes and sea level. Nature 324: 137-140.

Coe, A. L., Bosence, D. W. J., Church, K. D., Flint, S. S., Howell, J. A., Wilson, R. D. L. 2003. The sedimentary response to sea-level change, Coe, A. L. (ed.). The Open University. Cambridge University Press.

Cole, J. W. and Lewis, K. B. 1981. Evolution of the Taupo-Hikurangi subduction system. Tectonophysics 72: 1-21.

Cotton, C. A. 1918. The geomorphology of the coastal district of southwestern Wellington. Transactions of the New Zealand Institute 50: 212-221. 
Cowie, J. D.1963. Dune-building phases in the Manawatu District. New Zealand Journal of Geology and Geophysics 6(2): 268-280.

Cowie, J. D.1964. Loess in the Manawatu District. New Zealand Journal of Geology and Geophysics 7: 389-396.

Curray, J. R. 1964. Transgressions and regressions. In Papers in Marine Geology, Miller, L. (ed.). Macmillan, New York, pp. 175-203.

Dalrymple, R. W. 1992. Tidal depositional systems. In Walker, R. G. and James, N. P (eds.). Facies Models: response to sea level change. Geological Association of Canada, pp. 195-218.

Dalrymple, R. W., Zaitlin, B. A., Boyd, R. 1992. Estuarine facies models; conceptual basis and stratigraphic implications. Journal of Sedimentary Petrology 62 (6): 1130-1146.

Dawson, J. 1988. Forest vines to snow tussocks: the story of New Zealand plants. Victoria University Press, Wellington.

Dawson, J. 2000. Nature guide to New Zealand forests. Godwit, New Zealand.

Demarest, J. M. and Kraft, J. C. 1987. Stratigraphic record of Quaternary sea levels; implications for more ancient strata. SEPM Special Publication 41: 223-240.

Dominguez, J. M. L., Martin, L., Bittencourt, C. S. P. 1987. Sea-level history and Quaternary evolution of five mouth-associated beach ridge plains along the eastsoutheast Brazilian Coast: a summary. SEPM Special Publication 41: 115-128.

Dunbar, G. B. and Barrett, P. J. 2005. Estimating paleobathymetry of wave-graded continental shelves using sediment texture. Sedimentology 52 (2): 253-269. 
Dunbar, G. B., McLea, W., Goff, J. R. 1997. Holocene pollen stratigraphy and sedimentation, Wellington Harbour, New Zealand. New Zealand Journal of Geology and Geophysics 40: 325-333.

Edwards, A. R. 1987. An integrated biostratigraphy, magnetostratigraphy and Oxygen isotope stratigraphy for the late Neogene of New Zealand. New Zealand Geological Survey Record 23.

Fairbanks, R. G. 1989. A 17,000-year glacioeustatic sea level record: influence of glacial melting rates on the Younger Dryas event and deep-ocean circulation. Nature 342: 637-642.

Fleming, C. A. 1953. The geology of Wanganui subdivision. New Zealand Geological Survey Bulletin 52.

Fleming, C. A. 1970. Radiocarbon dating and pollen analysis from Otiran periglacial fans in western Wellington. Transactions of the Royal Society of New Zealand Geology 7: 197-208.

Fleming, C. A. 1972. The contribution of C14 dates to the Quaternary geology of the 'golden coast', western Wellington. Tuatara 19: 61-69.

Foley, G. A., Orr, T. O. H., Korsch, R. J. 1988. Environments of formation of lithologic associations in the Torlesse accretionary wedge, Tararua Range, New Zealand. New Zealand Journal of Geology and Geophysics 31: 197-181.

Friedman, G. M. 1961. Distinction between dune, beach, and river sands from their textural characteristics. Journal of Sedimentary Petrology 31 (4): 514-529.

Froggatt, P. C. 1983. Toward a comprehensive Upper Quaternary tephra and ignimbrite stratigraphy in New Zealand using electron microprobe analysis of glass shards. Quaternary Research 19: 188-200. 
Froggatt, P. C. and Lowe, D. J. 1990. A review of late Quaternary silicic and some other tephra formations from New Zealand: their stratigraphy, nomenclature, distribution, volume, and age. New Zealand Journal of Geology and Geophysics 33: 89-109.

Ghani, M. A. 1978. Late Cenozoic vertical crustal movements in the Southern North Island, New Zealand. New Zealand Journal of geology and Geophysics 22: 117126.

Gibb, J. G. 1983. Sea levels during the past 10000 years B.P. from the New Zealand region-South Pacific ocean. Abstracts of International Symposium on Coastal Evolution in the Holocene. Tokyo, Japan, pp. 28-31.

Gibb, J. G. 1986. A New Zealand regional Holocene eustatic sea-level curve and its implication to determination of vertical tectonic movements, a contribution to IGCP-Project 200. Royal Society of New Zealand Bulletin 24: 377-395.

Grant-Taylor, T. L. and Hornibrook, N. D. B. 1964. The Makara faulted outlier and age of Cook Strait. New Zealand Journal of Geology and Geophysics 7: 299-313.

Harris, W. F. 1953. Flora of the Rapanui Lignite. In Fleming, C. A. The Geology of Wanganui subdivision. New Zealand Geological Survey Bulletin 52, pp. 275.

Hays, J. D., Imbrie, J., Shackleton, N. J. 1976. Variations in the Earths orbit: Pacemaker of the ice ages. Science 194: 1121-1132.

Hayward, B. W. 1982. Associations of foraminifera (Protozoa : Sarcodina) of inner shelf sediments around Cavalli Island, north-east New Zealand. New Zealand Journal of Marine and Freshwater Research 16: 27-56.

Hayward, B. W. and Hollis, C. J. 1994. Brackish Foraminifera in New Zealand: A taxonomic and ecologic review. Micropaleontology 40 (3): 185-222. 
Hayward, B. W., Hollis, C. J., Grenfell, H. R. 1994. Foraminiferal associations in Port Pegasus, Stewart Island, New Zealand. New Zealand Journal of Marine and Freshwater Research 28 (1): 69-95.

Hayward, B. W., Grenfell, H., Cairns, G., Smith, A. 1996. Environmental controls on benthic Foraminiferal and Thecamoebian associations in a New Zealand tidal inlet. Journal of Foraminiferal Research 26 (2): 150-171.

Hayward, B. W., Hollis, C. J., Grenfell, H. R. 1997a. Recent Elphidiidae (Foraminiferida) of the South-west Pacific and fossil Elphidiidae of New Zealand. Institute of Geological and Nuclear Science monograph 16, 166 pp.

Hayward, B. W., Grenfell, H., Reid, K. 1997b. Foraminiferal associations in Wanganui Bight and Queen Charlotte Sound, New Zealand. New Zealand Journal of Marine and Freshwater Research 31: 337-365.

Hayward, B. W., Grenfell, H. R., Reid, C. M., Hayward, K. A. 1999. Recent New Zealand shallow-water benthic Foraminifera: taxonomy, ecological distribution, biogeography, and use in paleoenvironmental assessment. Institute of Geological and Nuclear Sciences monograph 21, 264pp.

Haywick, D. W. and Henderson, R. A. 1991. A foraminiferal palaeobathymetry of PlioPleistocene cyclothemic sequences, Petane Group, New Zealand. Palaios 6: 586599.

Hesp, P. A. 1975. The late Quaternary geomorphology of the lower Manawatu. Unpublished MSc Thesis, Massey University, Palmerston North.

Hesp, P. A. and Shepherd, M. J. 1978. Some aspects of the late Quaternary geomorphology of the lower Manawatu Valley, New Zealand. New Zealand Journal of Geology and Geophysics, 21(3): 403-412. 
Heusser, L. E. 1988. Pollen distribution in marine sediments on the continental margin off Northern California. Marine Geology 80: 131-147.

Heusser, L. E. and van de Geer, G. 1994. Direct correlation of terrestrial and marine paleoclimatic records from four glacial-interglacial cycles - DSDP Site 594 southwest Pacific. Quaternary Science Reviews 13: 273-282.

Holgate, G. P. 1985. Aspects of upper Quaternary stratigraphy of the Wanganui Basin. Unpublished MSc Thesis Victoria University of Wellington.

Holmes, P. L. 1994. The sorting of spores and pollen by water: experimental and field evidence. In Traverse, A. (ed.). Sedimentation of Organic Particles. Cambridge University Press pp. 9-32.

Hori, K., Saito, Y., Zhao, Q., Wang, P. 2002. Evolution of the coastal depositional system of the Changjiang (Yangtze) river in response to late Pleistocene-Holocene sea-level changes. Journal of Sedimentary Research 72 (6): 884-897.

Hunt, T. M. 1980. Basement structure of the Wanganui Basin, onshore, interpreted from gravity data. New Zealand Journal of Geology and Geophysics 23 (1): 1-16.

Imbrie, J., Hays, J. D., Martinson, D. G., McIntyre, A., Mix, A. C., Morley, J. J., Pisias, N. G., Prell, W. C., Shackleton, N. J. 1984. The orbital theory of Pleistocene climate: Support from a revised chronology of the marine $\delta^{18} \mathrm{O}$ record. In Berger et al. (eds.), Milankovitch and Climate. Dordrecht: Reidel.

Kohn, B. P., Pillans, B., McGlone, M. S. 1992. Zircon fission track ages for middle Pleistocene Rangitawa Tephra, New Zealand: Stratigraphic and paleoclimate significance. Paleogeography, Paleoclimatology, Paleoecology 95: 73-94.

Kovach. 2003. MVSP: Multi-Variate Statistical Package version 3.1. Kovach Computing Services, Pentraeth, Wales, U.K. 
Large, M. F. and Braggins, J. E. 1991. Spore atlas of New Zealand ferns and fern allies. Supplement New Zealand Journal of Botany 29.

Leckie, D. M. 1994. Canterbury Plains, New Zealand - Implications for sequence stratigraphic models. American Association of Petroleum Geologists Bulletin 78: 1240-1256.

Leckie, R. M. and Olson, H. V. 2003. Foraminifera as proxies for sea level change on siliciclastic margins. SEPM Special Publication 75: 5-19.

Lewis, K. B. 1979a. A storm-dominated inner shelf, Western Cook Strait, New Zealand. Marine Geology 31: 31-43.

Lewis, K. B. 1979b. Foraminifera on the Continental Shelf and Slope off Southern Hawke's Bay, New Zealand. New Zealand Oceanographic Institute Memoir 84.

Macphail, M. K. and McQueen, D. R. 1983. The value of New Zealand pollen and spores as indicators of Cenozoic vegetation and climates. Tuatara 26 (2): 37-59.

MacPherson, A. T. 1985. Stratigraphy and tephra correlations of Pleistocene sediments from the Finnis Road Area, Pohangina, Manawatu. Unpublished BSc hons. Thesis, Victoria University of Wellington.

McGlone, M. S. 1989. Pollen analysis, Bidwill Hill. Appendix 1 in Palmer, A. S., Vucetich, C. G., McGlone, M. S., Harper, M. A. Last Glacial loess and early Last Glacial vegetation history of Wairarapa Valley, New Zealand. New Zealand Journal of Geology and Geophysics 32 (4): 499-511.

McGlone, M. S. 2001. A late Quaternary pollen record from marine core P69, southeastern North Island, New Zealand. New Zealand Journal of Geology and Geophysics 44: 69-77. 
McGlone, M. S. 2002. A Holocene and latest Pleistocene pollen record from Lake Poukawa, Hawkes Bay, New Zealand. Global and Planetary Change 33 (3-4): 283-300.

McGlone, M. S. and Moar, N. T. 1977. The Ascarina decline and postglacial climatic change in New Zealand. New Zealand Journal of Botany 15: 485-489.

McGlone, M. S. and Topping, W. W. 1983. Late Quaternary vegetation, Tongariro region, central North Island, New Zealand. New Zealand Journal of Botany 21: 53-76.

McGlone, M. S., Neall, V. E., Pillans, B. J. 1984. Inaha Terrace deposits: a late Quaternary terrestrial record in South Taranaki, New Zealand. New Zealand Journal of Geology and Geophysics 27: 35-49.

McIntyre, D. J. 1963. Pollen analysis of a peat in Koputaroa dune-sand. Appendix in Cowie, J. D. Dune building phases in the Manawatu District, New Zealand. New Zealand Journal of Geology and Geophysics 6: 268-280.

McIntyre, D. J. 1970. Pollen analysis from the Lindale section, Paraparaumu. Appendix 1 in Fleming, C. A. Radiocarbon dating and pollen analysis from Otiran periglacial fans in western Wellington. Transactions of the Royal Society of New Zealand (earth sciences) 7: 197-208.

McKellar, M. H. 1973. Dispersal of Nothofagus pollen in eastern Otago, South Island, New Zealand. New Zealand Journal of Botany 11: 305-310.

McPherson, E. O. 1948. The Otaihanga faulted outlier and notes on the greensand deposit. New Zealand Journal of Science and Technology, September 194.

Miall, A. D. 1978. Facies types and vertical profile models in braided river deposits: a summary. In Miall, A. D. (ed.) Fluvial sedimentology. Canadian Society of Petroleum Geologists Memoir 5: 597-604. 
Miall, A. D. 1991. Stratigraphic sequences and their chronostratigraphic correlation. Journal of Sedimentary Petrology 61 (4): 497-505.

Miall, A. D. 1992. Alluvial deposits. In Walker, R. G. and James, N. P (eds.). Facies Models: response to sea level change. Geological Association of Canada, pp. 119142.

Mildenhall, D. C. 1979. Holocene pollen diagrams from Pauatahanui Inlet, Porirua, New Zealand. New Zealand Journal of Geology and Geophysics 22 (5): 585-591.

Mildenhall, D. C. 1991. Pollen analysis from two samples in the Otaki Formation. Appendix E in Sewell, A. H. Paleoenvironmental analysis of Quaternary strata in the Levin area. Unpublished MSc Thesis, Massey University, Palmerston North, New Zealand.

Mildenhall, D. C. 1994. Palynostratigraphy and paleoenvironments of Wellington, New Zealand, during the last $80 \mathrm{ka}$, based on palynology of drillholes. New Zealand Journal of Geology and Geophysics 37: 421-436.

Milne, J. D. G. 1973. Upper Quaternary geology of the Rangitikei drainage basin, North Island, New Zealand. Unpublished PhD Thesis, Victoria University of Wellington $347 \mathrm{pp}$.

Milne, J. D. G. and Smalley, J. J. 1979. Loess deposits in the southern part of the North Island of New Zealand: an outline stratigraphy. Acta Geoloca Academiae Scientiarium Hungaercae.

Mitchell, J. K. 2001. A lithostratigraphic and cyclostratigraphic study of Late Pliocene to Early Pleistocene strata within the Wanganui Valley, Parikino to Upokongaro, Wanganui basin, New Zealand. Unpublished MSc Thesis Victoria University of Wellington. 
Moar, N. T. 1970. Recent pollen spectra from 3 locations in the South Island, New Zealand. New Zealand Journal of Botany 8: 210-221.

Moar, N. T. 1971. Contributions to the Quaternary history of the New Zealand flora 6. Aranuian pollen diagrams from Canterbury, Nelson, and north Westland, South Island. New Zealand Journal of Botany 9: 80-145.

Moar, N. T. 1993. Pollen grains of New Zealand dicotyledonous plants. Manaaki Whenua Press, Lincoln, Canterbury, New Zealand.

Moore, P. D. and Webb, J. A. 1978. An illustrated guide to pollen analysis. Blackwell Scientific Publications.

Moore, P. D., Webb, J. A., Collinson, M. E. 1991. Pollen Analysis Second Edition. Blackwell Scientific Publications.

Murray, J. W. 1991. Ecology and palaeoecology of Benthic Foraminifera. Longman Scientific and Technical, England pp.397.

Naish, T. and Kamp, P. J. J. 1997a. Sequence stratigraphy of sixth-order (41 k.y.) Pliocene-Pleistocene cyclothems, Wanganui basin, New Zealand: A case for the regressive systems tract. Geological Society of America Bulletin 109 (8): 978-999.

Naish, T. and Kamp, P. J. J. 1997b. Foraminiferal depth paleoecology of Late Pliocene shelf sequences and systems tracts, Wanganui Basin, New Zealand. Sedimentary Geology 110: 237-255.

Neef, G. 1999. Neogene development of the inland part of the forearc in northern Wairarapa, North Island, New Zealand: A synthesis. New Zealand Journal of Geology and Geophysics 42 (1): 113-135.

Oliver, R. L. 1948. The Otaki Sandstone and its geological history. New Zealand Geological Survey memoir 7. 
Palmer, A.; Barnett, R.; Pillans, B.; Wilde, R. 1988. Loess, river aggradation terraces and marine benches at Otaki, Southern North Island, New Zealand. In Eden, D. N. and Furkert, R. J. (eds.) Loess: its distribution, geology and soils. Balkema, Rotterdam, 163-174.

Pemberton, S. G., MacEachem, J. A., Frey, R. W. 1992. Trace fossils facies models; environmental and allostratigraphic significance. In Walker, R. G. and James, N. P (eds.). Facies Models: response to sea level change. Geological Association of Canada.

Perrett, T. L. 1990. Variations in sediment texture and biota off a wave dominated coastline, Peka Peka Beach, New Zealand. Unpublished MSc Thesis, School of Earth Sciences, Victoria University of Wellington.

Pickrill, R. A. 1987. Circulation and sedimentation of suspended particulate matter in New Zealand fiords. Marine Geology 74: 21-39.

Pillans, B. 1983. Upper Quaternary marine terrace chronology and deformation, South Tarakani, New Zealand. Geology 11: 292-297.

Pillans, B. 1986. A Late Quaternary uplift map for North Island, New Zealand. Royal Society of New Zealand Bulletin 24: 409-417.

Pillans, B. 1988. Loess Chronology in Wanganui Basin, New Zealand. In Eden, D. N. and Furkert, R. J. (eds.), Loess, its distribution, geology, and soils. Balkema, Rotterdam.

Pillans, B. 1991. New Zealand Quaternary stratigraphy: an overview. Quaternary Science Reviews 10: 405-418.

Pillans, B. 1994. Direct marine-terrestrial correlations, Wanganui Basin, New Zealand: the last 1 million years. Quaternary Science Reviews 13: 189-200. 
Pillans, B., Holgate, G., McGlone, M. 1988. Climate and sea level during Oxygen Isotope Stage 7b: On-land evidence from New Zealand. Quaternary Research 29: 176-185.

Pocknall, D. T. 1978. Relative pollen representation in relation to vegetation composition, Westland, New Zealand. New Zealand Journal of Botany 16: 379186.

Pocknall, D. 1984. Palynology of S25/4 - Ranui Road, Otaki. Appendix 4 in Barnett, R. Upper Quaternary stratigraphy in the Otaki District. Unpublished BSc hons. Thesis. Victoria University of Wellington.

Posamentier, H. W. and Vail, P. R. 1988. Eustatic controls on clastic deposition 2. In Wilgus, C. K. et al. (eds.), Sea Level Changes: an integrated approach. SEPM Special Publication 42: 124-154.

Reinson, G. E. 1992. Transgressive barrier island and estuarine systems. In Walker, R. G. and James, N. P (eds.). Facies Models: response to sea level change. Geological Association of Canada, pp. 179-194.

Rich C. C. 1959. Late Cenozoic Geology of the Lower Manawatu Valley, New Zealand. PhD Thesis, Harvard University, Cambridge, Massachusetts.

Rust, B. R. 1972. Structure and process in a braided river. Sedimentology 18: 221-245.

Saul, G., Naish, T. R., Abbott, S. T., Carter, R. M. 1999. Sedimentary cyclicity in the marine Pliocene-Pleistocene of the Wanganui Basin (New Zealand): Sequence stratigraphy motifs characteristic of the past 2.5m.y. GSA Bulletin, 111(4): 524537.

Seward, D. 1976. Tephrostratigraphy of the marine sediments in the Wanganui Basin, New Zealand. New Zealand Journal of Geology and Geophysics 19 (1): 9-20. 
Sewell, A. H. 1991. Paleoenvironmental analysis of Quaternary strata in the Levin area. Unpublished MSc Thesis, Massey University, Palmerston North, New Zealand.

Shackleton, N. J., Berger, A., Peltier, W. R. 1990. An alternative astronomical calibration of the lower Pleistocene timescale based on OPD Site 677. Transactions of the Royal Society of Edinborough 81: 251-261.

Shane, P. 2000. Tephrochronology: a New Zealand case study. Earth Science Reviews 49: 223-259.

Shane, P. A. R., Black, T. M., Alloway, B. V., Westgate, J. A. 1996. Early to middle Pleistocene tephrochronology of North Island. New Zealand: Implications for volcanism, tectonism, and paleoenvironments. GSA Bulletin 108 (8): 915-925.

Shepherd, M. J. 1985. The origin of the Koputaroa dunes, Horowhenua, New Zealand. New Zealand Journal of Geology and Geophysics 28: 323-327.

Shepherd, M. J. 1987. Holocene alluviation and transgressive dune activity in the lower Manawatu Valley, New Zealand. New Zealand Journal of Geology and Geophysics 30: 175-187.

Stern, T. A., Quinlan, G. M., Holt, W. E. 1992. Basin formation behind an active subduction zone: three-dimensional flexural modelling of Wanganui Basin, New Zealand. Basin Research 4: 197-214.

Swift, D. J. P. and Thorne, J. A. 1991. Sedimentation on a continental margin, 1: a general model for shelf sedimentation. Special Publications International Association of Sedimentology 14: 3-31.

Te Punga, M. T. 1952. The geology of Rangitikei Valley, New Zealand. Geological Survey Memoirs 8, $44 \mathrm{pp}$. 
Te Punga, M. T. 1954a. The Late Tertiary and Quaternary geological history of western Wellington. Unpublished PhD Thesis, Victoria University of Wellington.

Te Punga, M. T. 1954b. Fossiliferous beds found in a well at Awahuri, near Palmerston North. New Zealand Journal of Science and Technology B36: 89-92.

Te Punga, M. T. 1957. Live Anticlines In Western Wellington. New Zealand Journal of Science and Technology, 38(5): 433-446.

Te Punga, M. T. 1962. Some geological features of the Otaki-Waikanae district. New Zealand Journal of Geology and Geophysics 5 (4): 517-530.

Thom, B. G. 1983. Transgressive and regressive stratigraphies of coastal sand barriers in southeast Australia. Marine Geology 56: 137-158.

Vail, P. 1987. Seismic stratigraphy interpretation using sequence stratigraphy: Part 1. Seismic stratigraphy interpretation procedure. In Bally, A. W. (ed.), Atlas of Seismic Stratigraphy 27, AAPG, Tulsa.

Van Wagoner, J. C. 1995. Overview of sequence stratigraphy of foreland basin deposits: Terminology, summary of papers, and glossary of sequence stratigraphy in Van Wagoner, J. C., Bertram, G. T., eds., sequence stratigraphy of foreland basin deposits. American Association of Petroleum Geologists Memoir 64: 9-21.

Van Wagoner, J. C., Posamentier, H. W., Mitchum, R. M., Vail, P. R., Sarg, J. F., Lutit, T. S., Hardenbol, J. 1988. An overview of sequence stratigraphy and key definitions. In Wilgus, C. K. et al. (eds.), Sea Level Changes: an integrated approach. SEPM Special Publication 42: 124-154.

Vella, P. 1963. Upper Pleistocene succession in the inland part of Wairarapa Valley, New Zealand. Transactions of the Royal Society of New Zealand Geology 2 (4): 63-78. 
Walcott, R. I. 1978. Present tectonics and Late Cenozoic evolution of New Zealand. Geophysical Journal of the Royal Astrological Society 52: 137-164.

Walker, R. G. and James, N. P. 1992. Facies Models: response to sea level change. Geological Association of Canada.

Wellman, H. W. 1948. Tararua Range summit height accordance. New Zealand Journal of Science and Technology B30: 123-127.

Williams, D. F., Thunell, R. C., Tappa, E., Rio, D., Raffi, I. 1988. Chronology of the Pleistocene Oxygen isotope record: $0-1.88$ m.y. B.P. Palaeogeography, Palaeoclimatology, Palaeoecology 64: 221-240.

Wilmshurst, J. M., Eden, D. N., Froggatt, P. C. 1999. Late Holocene forest disturbance in Gisborne, New Zealand: a comparison of terrestrial and marine pollen records. New Zealand Journal of Botany 37: 523-540.

Yoo, D. G., Lee, C. W., Kim, S. P., Jin, J. K., Han, H. C. 2002. Late Quaternary transgressive and highstand systems tracts in the northern East China Sea midshelf. Marine Geology 187: 313-328. 


\section{APPENDIX A: \\ LEVIN INVESTIGATION BORE LOG MAIN ROAD SOUTH, LEVIN, HOROWHENUA \\ (GR $27017006061200 ;+28 \mathrm{~m}$ above present sea level)}

Drilled by N. Webb and Sons drilling Company (Levin) between the period $12 / 10 / 2003$ to $04 / 04 / 2004$, using cable tool percussion drilling rig. The hole was cased continuously to prevent cave in. Hole diameter was $0.6 \mathrm{~m}$.

A maximum depth of $277.30 \mathrm{~m}$ was reached (248.30m below present sea level)

Vertical scale on bore $\log$ is 1:100. Each page shows $20 \mathrm{~m}$ of vertical strata. Note thicknesses are not corrected for dip.

Graphic log illustrates mud, silt, fine sand, coarse sand, and gravel with sedimentological information and fossil occurrences (key below).

\section{Summary of symbols used}

Sedimentary structures

(where appplicable)

当 Peat lens

- Mud lens

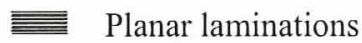

Sedimentology

Rounded-well rounded clasts

$\longrightarrow$ Disc/rod shaped clasts
Fossil records

2. Broken shell fragments

(2) Whole bivalve shells

䚁 Whole gastropod shells

Worm tubes

W Wood

M) Peat 


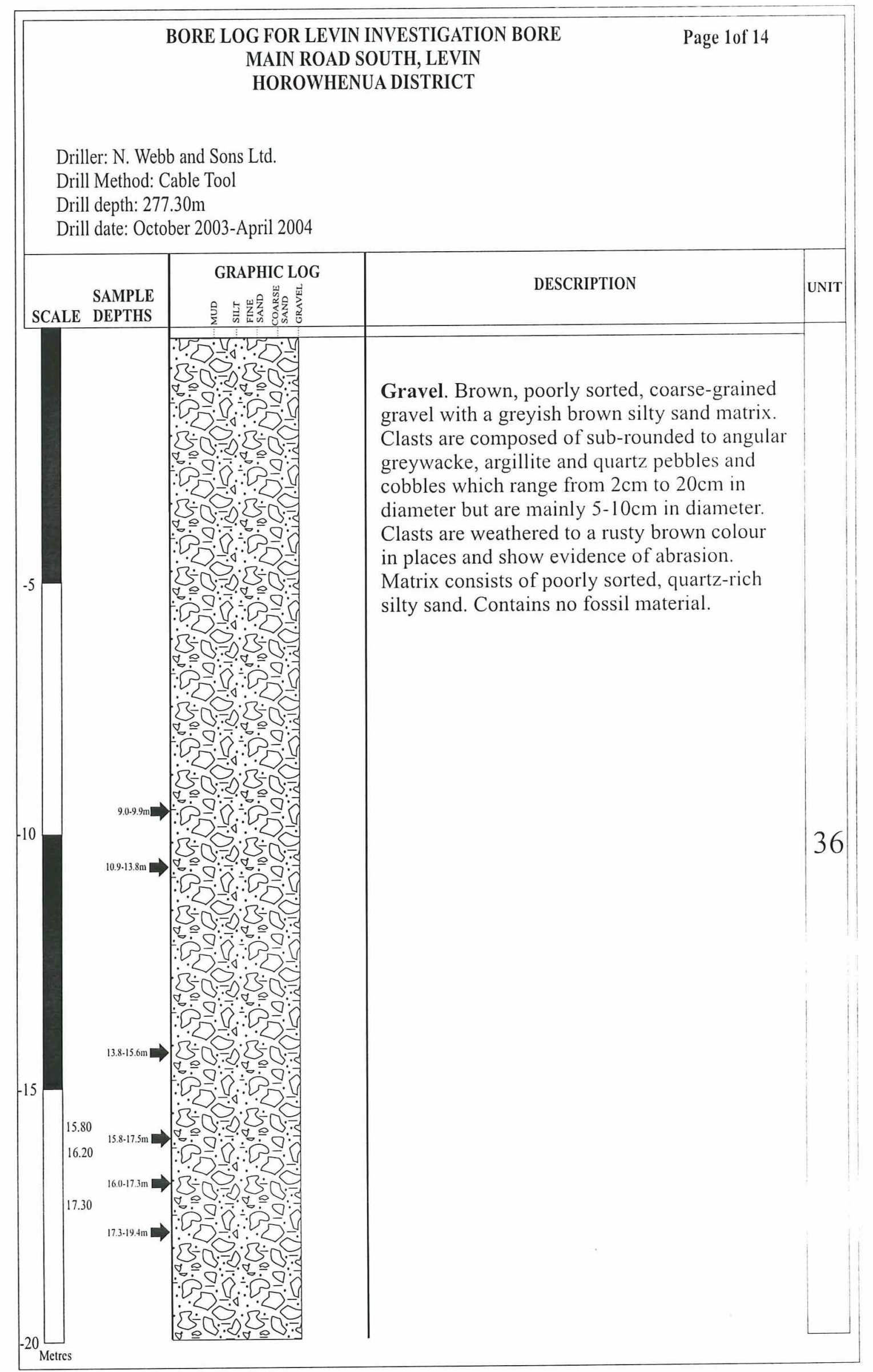




\section{BORE LOG FOR LEVIN INVESTIGATION BORE MAIN ROAD SOUTH, LEVIN HOROWHENUA DISTRICT}

Driller: N. Webb and Sons Ltd.

Drill Method: Cable Tool

Drill depth: $277.30 \mathrm{~m}$

Drill date: October 2003-April 2004

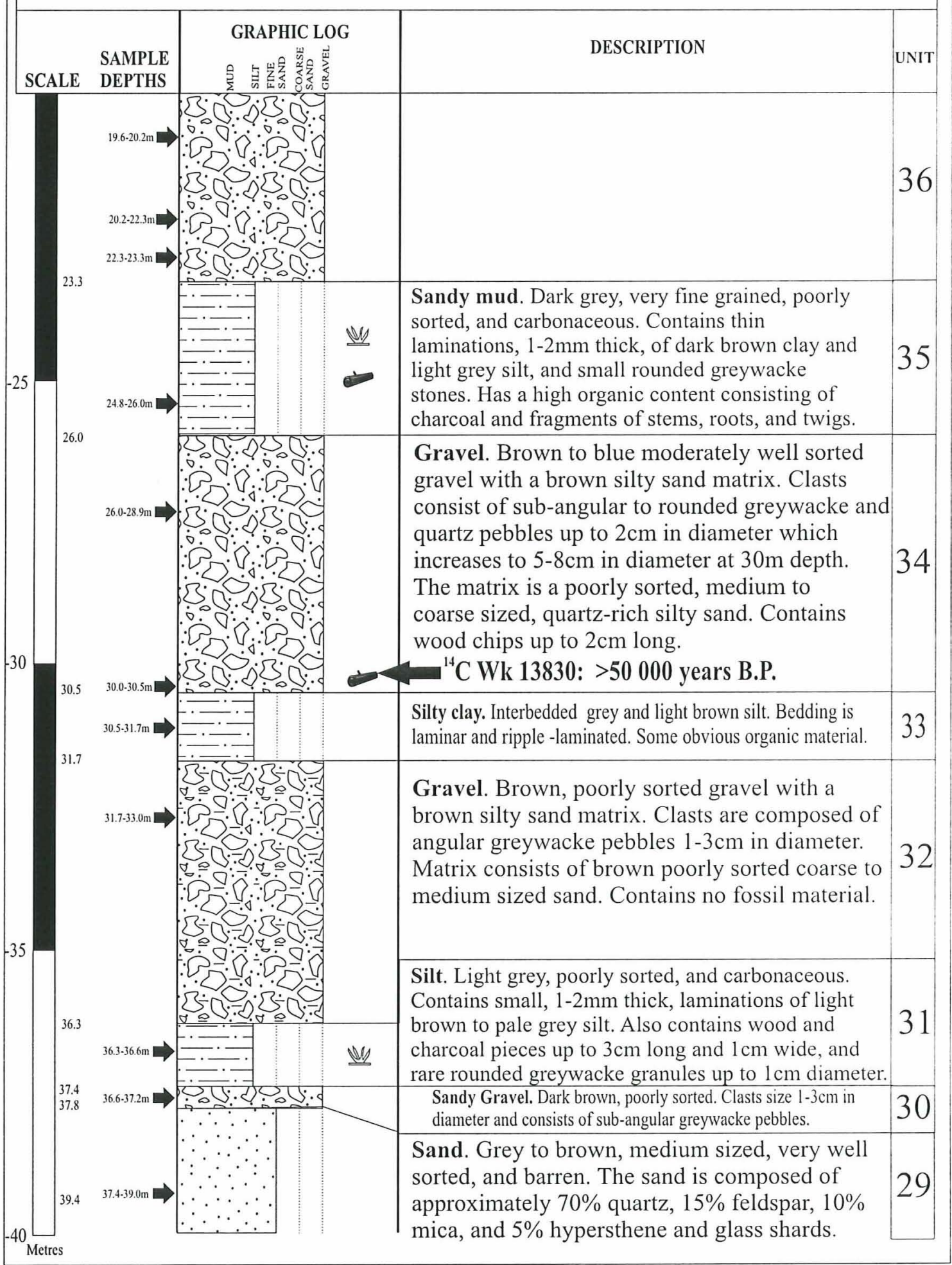




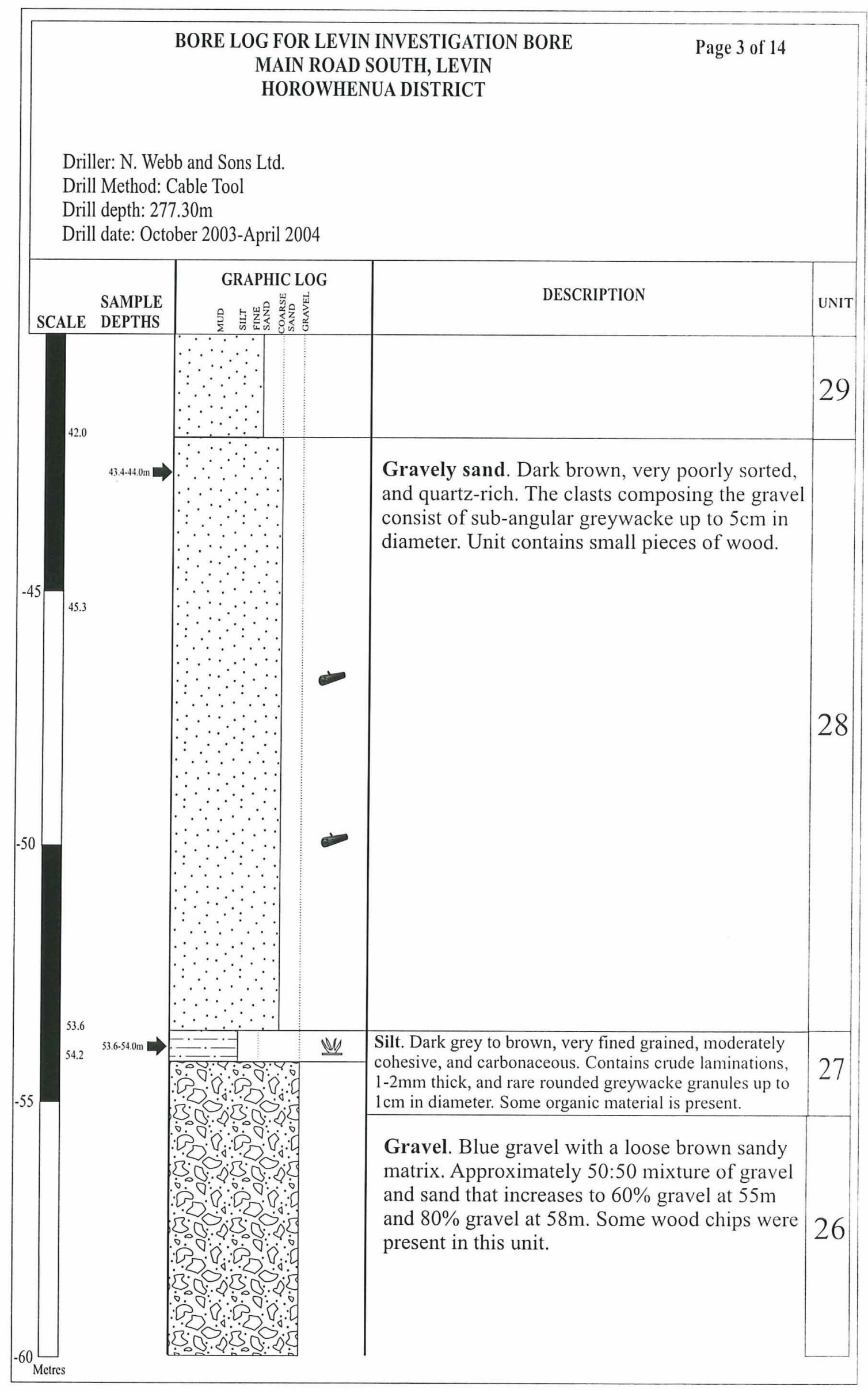




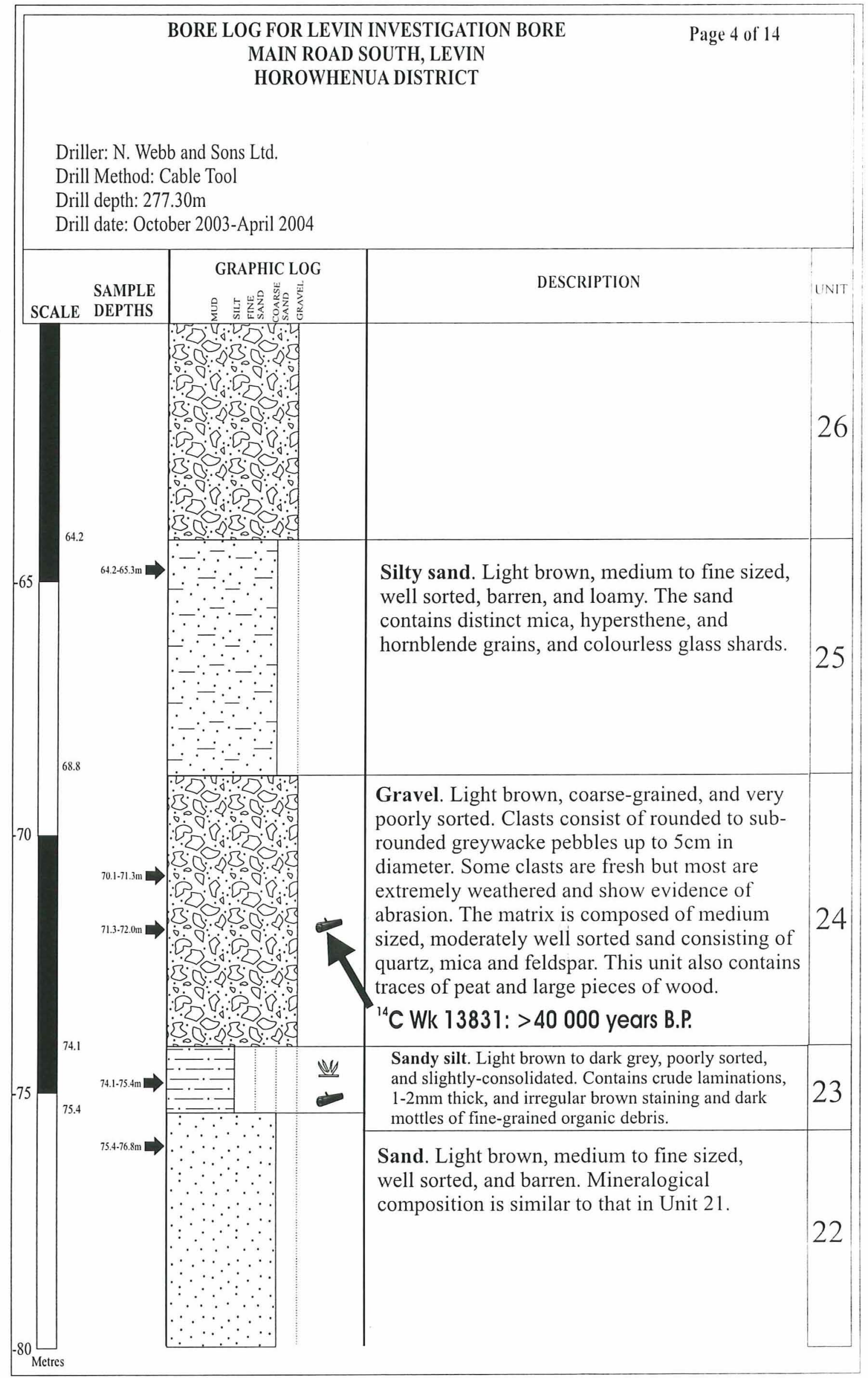




\section{BORE LOG FOR LEVIN INVESTIGATION BORE \\ MAIN ROAD SOUTH, LEVIN \\ HOROWHENUA DISTRICT}

Page 5 of 14

Driller: N. Webb and Sons Ltd.

Drill Method: Cable Tool

Drill depth: $277.30 \mathrm{~m}$

Drill date: October 2003-April 2004

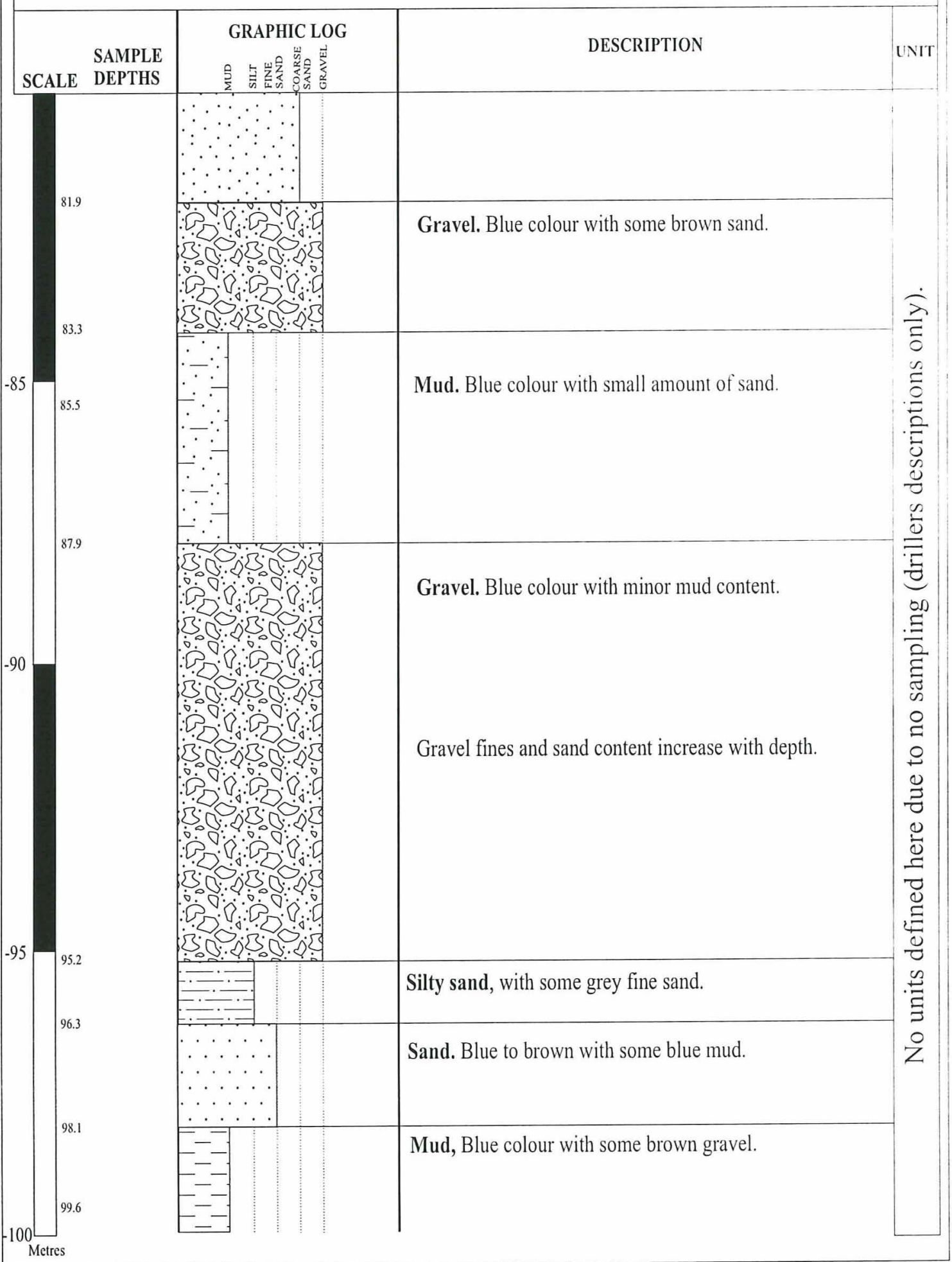




\section{BORE LOG FOR LEVIN INVESTIGATION BORE \\ MAIN ROAD SOUTH, LEVIN \\ HOROWHENUA DISTRICT}

Page 6 of 14

Driller: N. Webb and Sons Ltd.

Drill Method: Cable Tool

Drill depth: $277.30 \mathrm{~m}$

Drill date: October 2003-April 2004

\begin{tabular}{|c|c|c|c|c|}
\hline SCALE & $\begin{array}{l}\text { SAMPLE } \\
\text { DEPTHS }\end{array}$ & 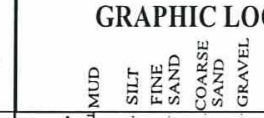 & DESCRIPTION & UNIT \\
\hline & & & $\begin{array}{l}\text { Sand. Grey, fine to very fine sized, very well } \\
\text { sorted, and barren. The sand is composed of } \\
\text { approximately } 85 \% \text { quartz, } 10 \% \text { muscovite, } \\
\text { and } 5 \% \text { biotite grains. }\end{array}$ & \\
\hline 110.4 & 1114.5114.8m $\Rightarrow$ & $\begin{array}{l}30 \\
00 \\
0 \\
0 \\
0\end{array}$ & $\begin{array}{l}\text { Gravel. Blue, coarse-grained, poorly sorted } \\
\text { gravel with grey coarse sandy matrix. Clasts } \\
\text { consist of angular to sub-rounded greywacke } \\
\text { pebbles and cobbles up to } 10 \mathrm{~cm} \text { in diameter, } \\
\text { mostly } 1-4 \mathrm{~cm} \text {. Matrix is composed of grey, } \\
\text { moderately well sorted gritty sand and mud. A } \\
\text { thin lens of material that is similar to the matrix } \\
\text { occurs between } 109-110 \mathrm{~m} \text { depth. }\end{array}$ & 20 \\
\hline
\end{tabular}




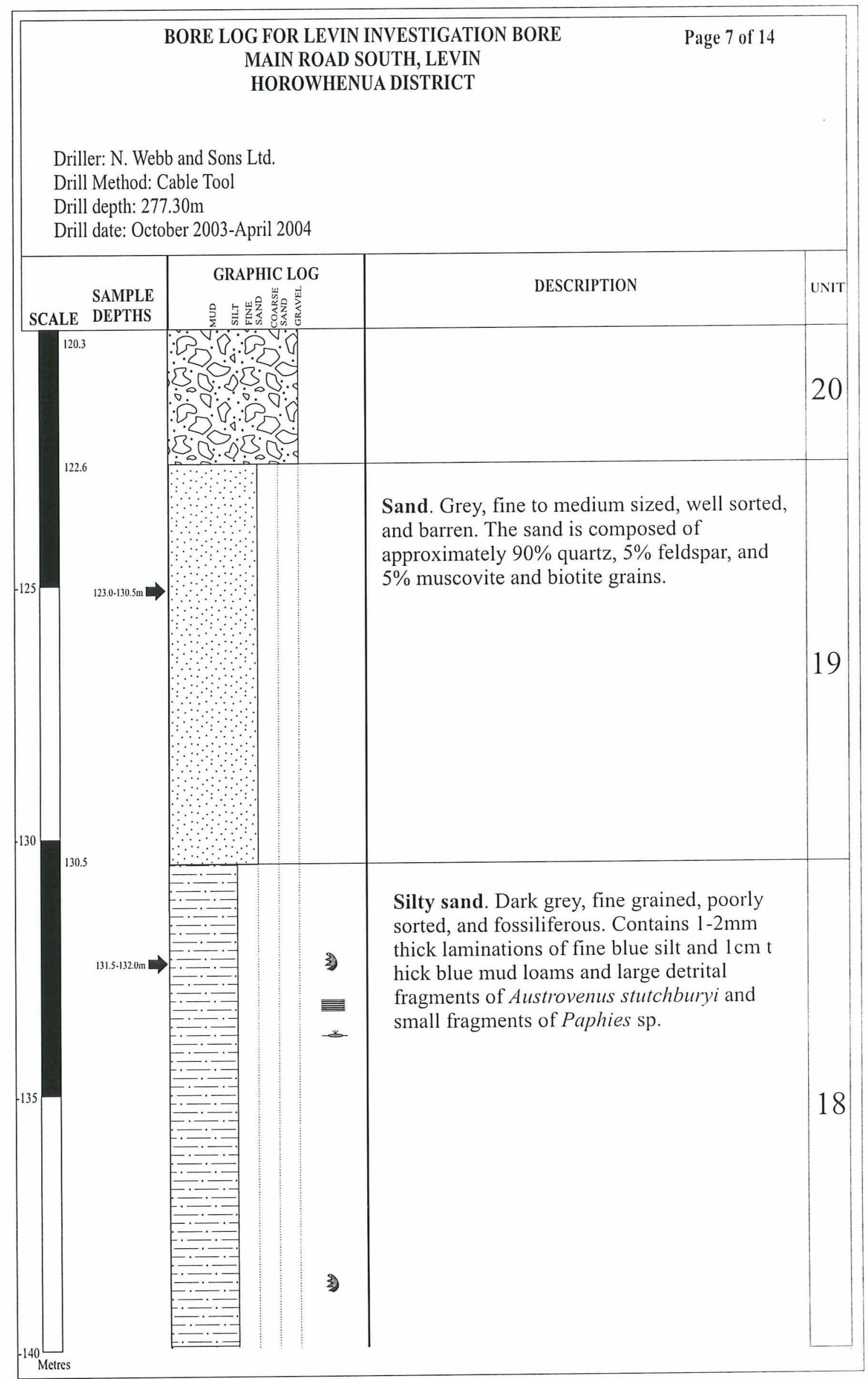




\section{BORE LOG FOR LEVIN INVESTIGATION BORE \\ MAIN ROAD SOUTH, LEVIN \\ HOROWHENUA DISTRICT}

Page 8 of 14

Driller: N. Webb and Sons Ltd.

Drill Method: Cable Tool

Drill depth: $277.30 \mathrm{~m}$

Drill date: October 2003-April 2004

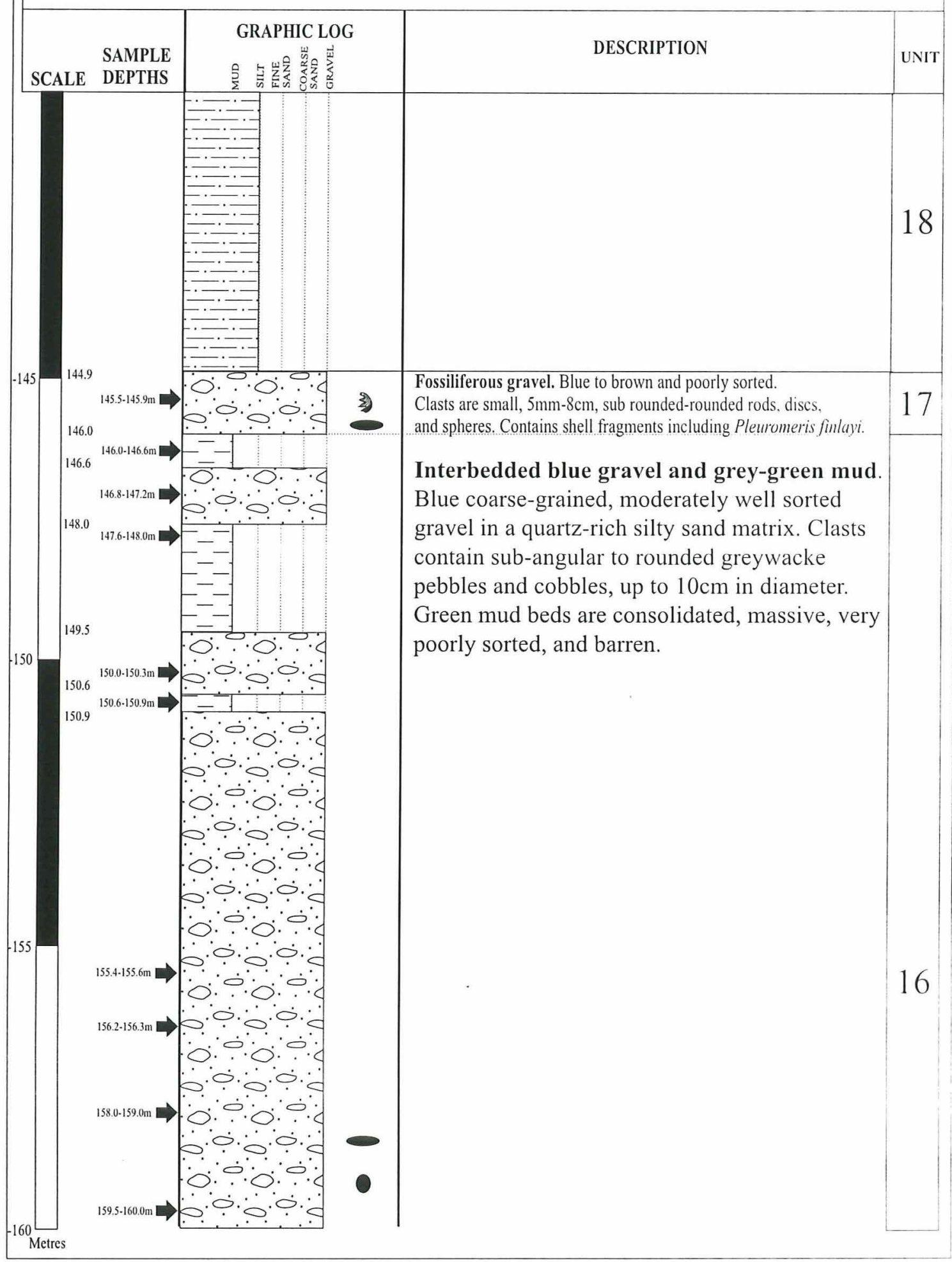




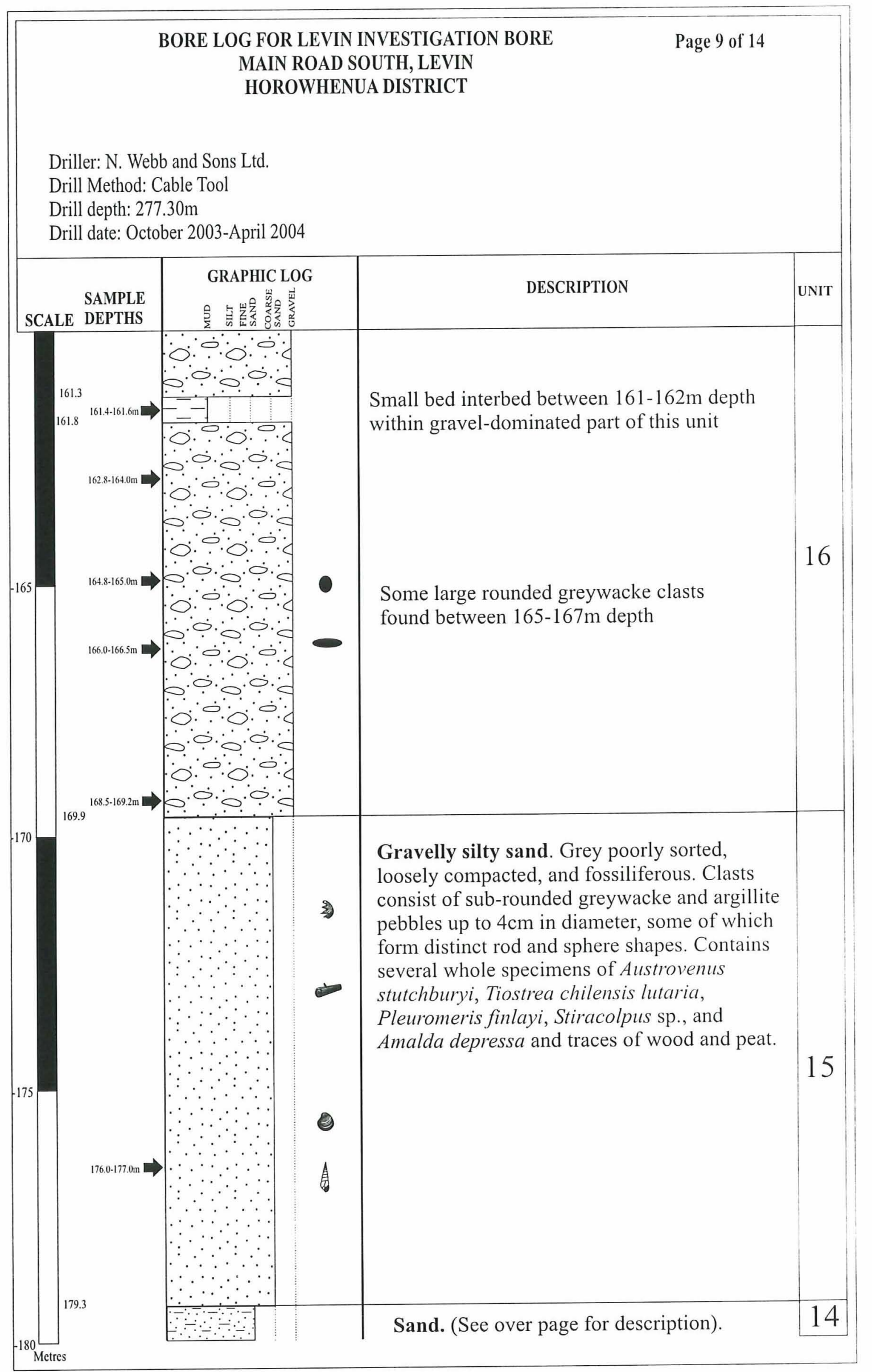




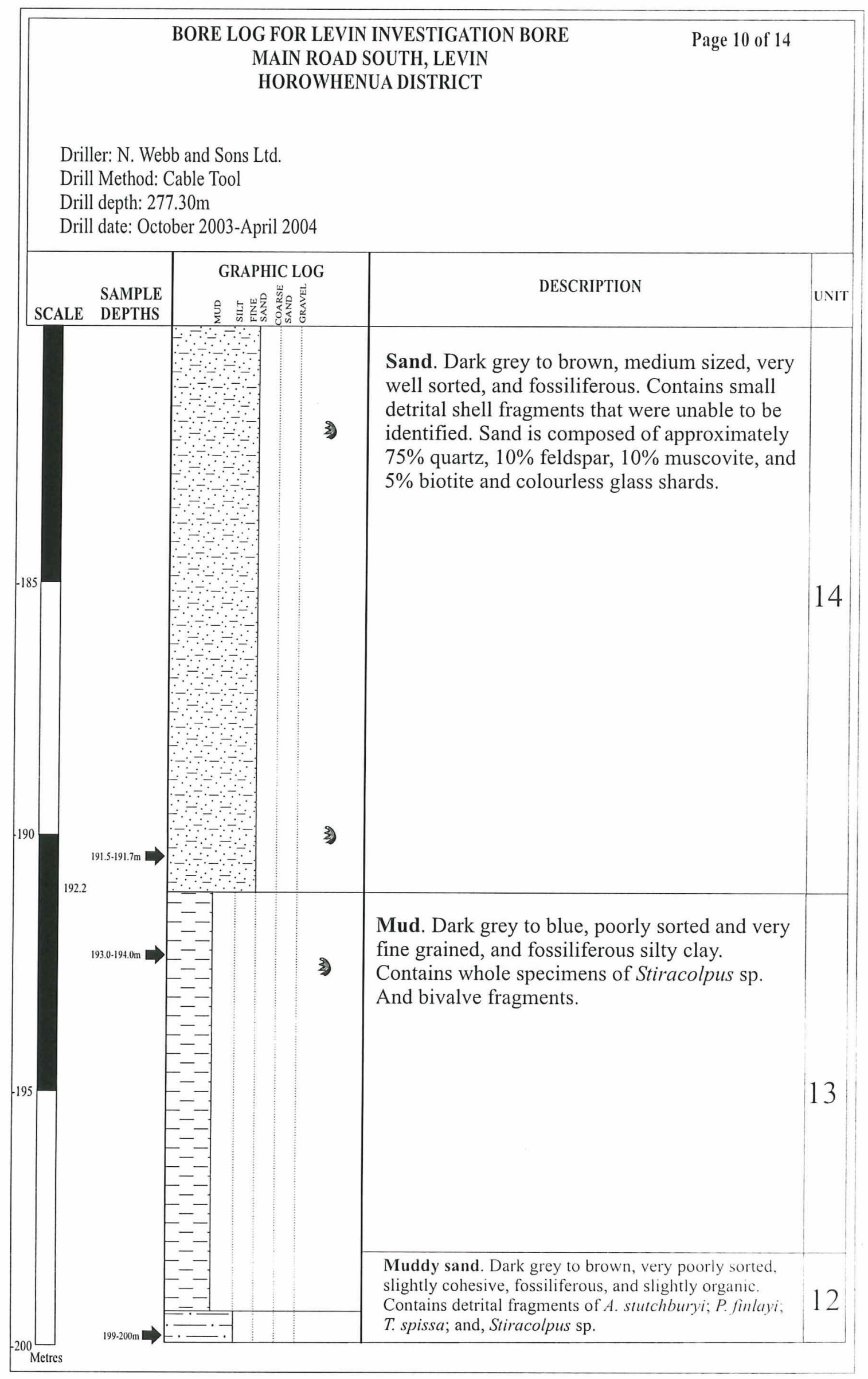




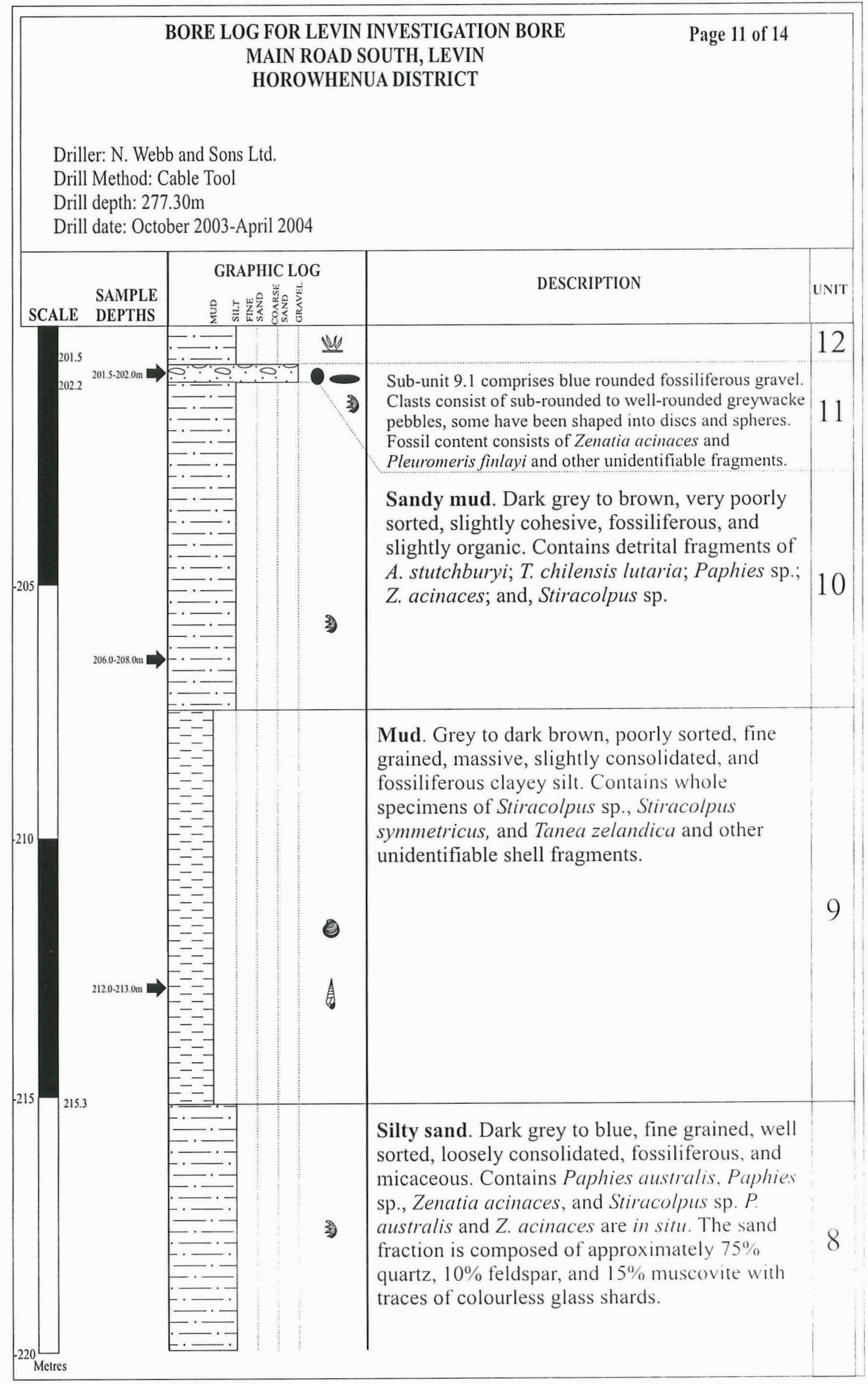




\section{BORE LOG FOR LEVIN INVESTIGATION BORE \\ MAIN ROAD SOUTH, LEVIN \\ HOROWHENUA DISTRICT}

Page 12 of 14

Driller: N. Webb and Sons Ltd.

Drill Method: Cable Tool

Drill depth: $277.30 \mathrm{~m}$

Drill date: October 2003-April 2004

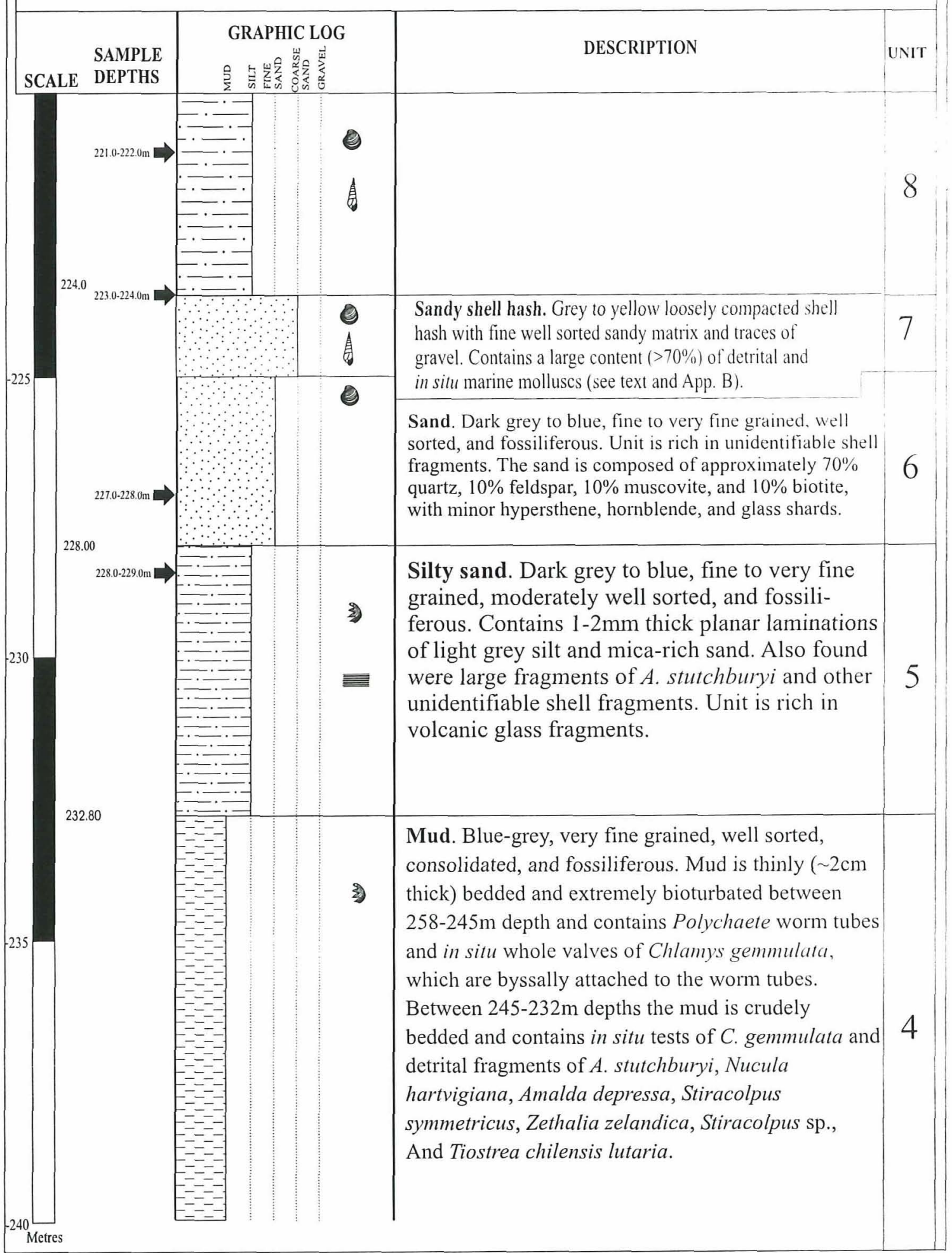




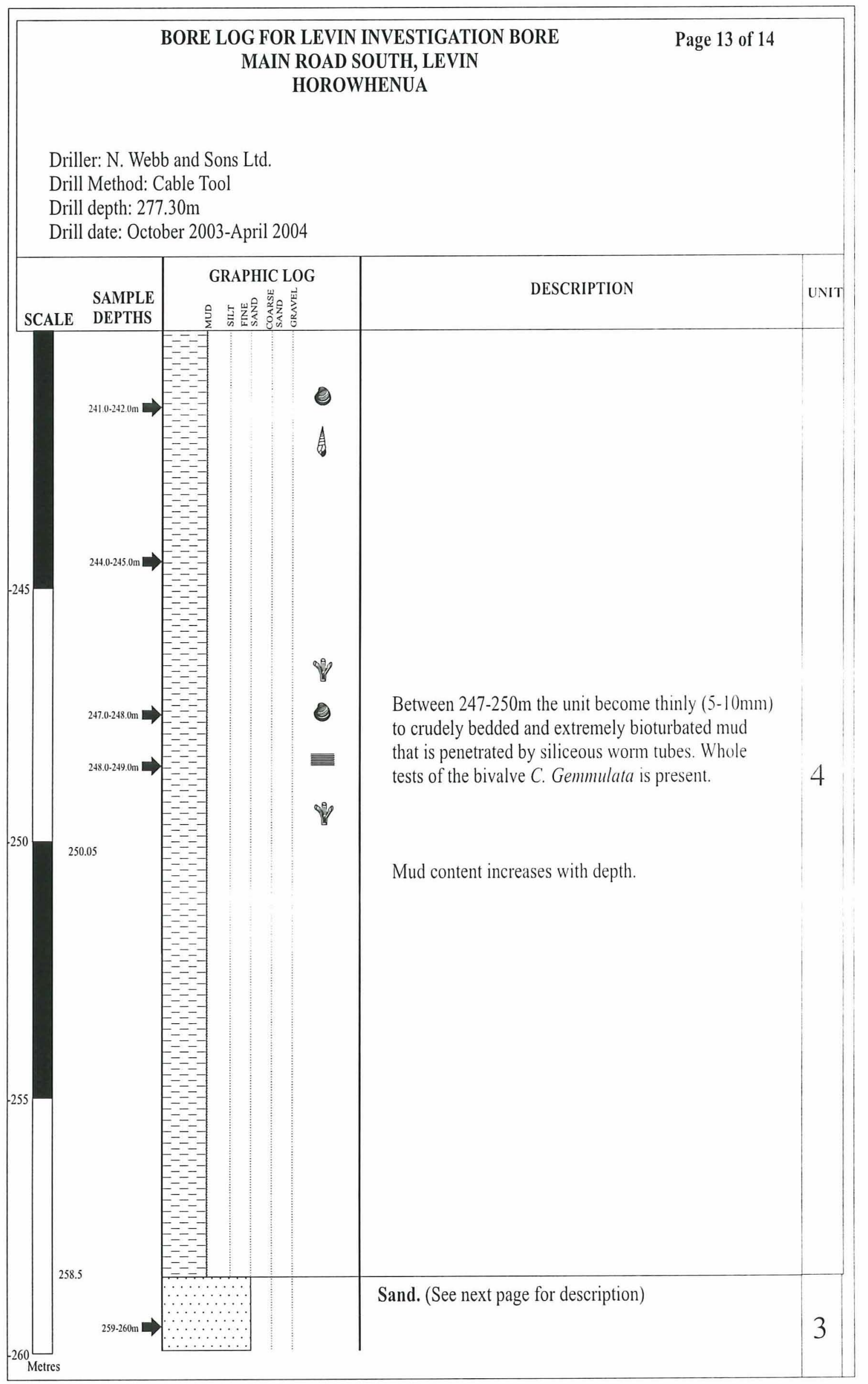




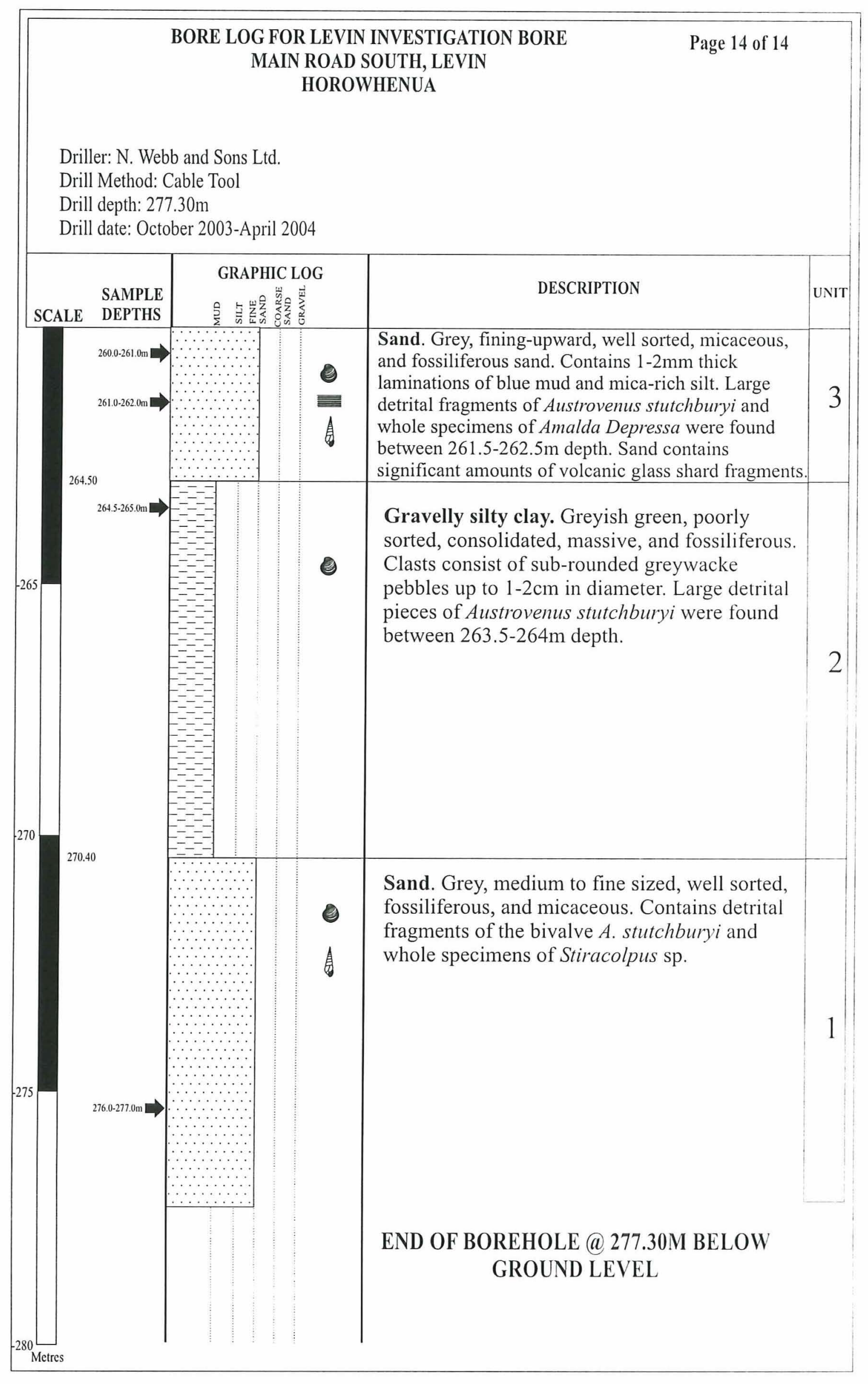




\section{LIST OF SAMPLES}

\begin{tabular}{|l|}
\hline $159.5-160.0$ \\
\hline $161.4-161.6$ \\
\hline $162.8-164.0$ \\
\hline $164.8-165.0$ \\
\hline $166.0-166.5$ \\
\hline $168.5-169.2$ \\
\hline $176.0-177.0$ \\
\hline $191.5-191.7$ \\
\hline $193.0-194.0$ \\
\hline $199.0-199.7$ \\
\hline $201.5-201.8$ \\
\hline $206.0-208.0$ \\
\hline $212.0-213.0$ \\
\hline $221.0-222.0$ \\
\hline $223.0-224.0$ \\
\hline $227.0-228.0$ \\
\hline $228.0-229.0$ \\
\hline $241.0-242.0$ \\
\hline $244.0-245.0$ \\
\hline $247.0-248.0$ \\
\hline $248.0-249.0$ \\
\hline $259.5-260.5$ \\
\hline $260.5-261.5$ \\
\hline $261.5-262.5$ \\
\hline $263.5-264.0$ \\
\hline $276.0-277.0$ \\
\hline
\end{tabular}

\begin{tabular}{|l|}
\hline \multicolumn{1}{|c|}{$\begin{array}{c}\text { Sample } \\
\text { Depths } \\
(\mathbf{m})\end{array}$} \\
\hline $9.0-9.9$ \\
\hline $10.9-13.8$ \\
\hline $13.8-15.6$ \\
\hline $15.8-17.5$ \\
\hline $16.0-17.3$ \\
\hline $17.3-19.4$ \\
\hline $19.6-20.2$ \\
\hline $20.2-22.3$ \\
\hline $22.3-23.3$ \\
\hline $24.8-26.0$ \\
\hline $29.0-28.9$ \\
\hline $30.0-30.5$ \\
\hline $30.5-31.7$ \\
\hline $31.7-33.3$ \\
\hline $36.3-36.6$ \\
\hline $36.6-37.2$ \\
\hline $37.4-39.0$ \\
\hline $39.4-40.0$ \\
\hline $43.4-44.0$ \\
\hline $53.6-54.0$ \\
\hline $64.2-65.3$ \\
\hline $70.1-71.3$ \\
\hline $71.3-72.0$ \\
\hline $74.1-75.4$ \\
\hline $75.4-76.8$ \\
\hline $106.0-107.0$ \\
\hline $111.5-111.8$ \\
\hline $114.5-114.8$ \\
\hline $116.5-117.0$ \\
\hline $123.0-130.5$ \\
\hline $131.5-132.0$ \\
\hline $145.5-145.9$ \\
\hline $146.0-146.6$ \\
\hline $146.8-147.2$ \\
\hline $147.6-148.0$ \\
\hline $150.0-150.3$ \\
\hline $150.6-150.9$ \\
\hline $155.4-155.6$ \\
\hline $156.2-156.3$ \\
\hline $158.0-159.0$ \\
\hline
\end{tabular}




\section{Appendix B: \\ MACROFOSSIL IDENTIFICATION, TAXONOMY, AND PALEOENVIRONMENTAL DETERMINATION FOR LEVIN BOREHOLE SAMPLES}

Macrofossils were selected from the Levin borehole cuttings and cleaned in an ultrasonic tank. They were identified using the Victoria University School of Earth Sciences reference collection and New Zealand Geological Survey Paleontological Bulletin 58 'Cenozoic Mollusca of New Zealand' (Beu and Maxwell, 1990).

\section{Fossil record for sample taken from $131.5-132.0 \mathrm{~m}$ depth}

Bivalvia: Austrovenus stutchburyi (Gray), several large fragments.

Paphies sp., few fragments.

Ecology: Slightly brackish subtidal to intertidal part of an estuary.

\section{Fossil record for sample taken from $176-177 \mathrm{~m}$ depth}

Bivalvia: Austrovenus stutchburyi; several whole valves, some large abraded fragments. Tiostrea chilensis lutaria (Hutton); few whole valves (leached). Pleuromeris finlayi (Powell); few whole valves (fresh).

Gastropoda: Stiracolpus sp.; whole specimens and fragments. Amalda depressa (Sowerby); one whole specimen (fresh).

Ecology: Shallow water (5m?) low salinity environment. Possibly in the subtidal mid upper reaches of an estuary that was relatively sheltered with solid rock exposures.

Fossil record for sample taken from 193.0-194.0m depth

Gastropoda: Stiracolpus sp.; small whole shells and large fragments 
Ecology: Shallow marine environment.

\section{Fossil record for sample taken from 199.0-199.7m depth}

Bivalvia: Austrovenus stutchburyi; several fragments, highly abraded.

Pleuromeris finlayi; one whole valve and several fragments.

Tawera spissa (Deshayes); several fresh fragments.

Gastropoda: Stiracolpus sp.; several whole specimens, fresh.

Ecology: Nearshore shallow water environment. Moderately sheltered subtidal zone in a bay or outer estuary.

Fossil record for sample taken from 201.5-201.8m depth

Bivalvia: Zenatia acinaces (Quoy and Gaimerd); one fresh fragment.

Pleuromeris finlayi; one whole valve.

Ecology: Soft muddy bottomed environment.

Fossil record for sample taken from 206.0-208.0m depth

Bivalvia: Austrovenus stutchburyi; many fragments.

Zenatia acinaces; few small fragments.

Paphies sp.; few small fragments.

Tiostrea chilensis lutaria; several fragments (abraded).

Gastropoda: Stiracolpus sp.; several large fragments, fresh.

Ecology: Subtidal zone in the mid to upper reaches of an estuary or sheltered bay.

Fossil record for sample taken from 212.0-213.0m depth 
Gastropoda: Stiracolpus sp.; several whole specimens, fresh.

Stiracolpus symmetricus (Hutton); one large abraded specimen.

Tanea zelandica (Quoy and Gaimard); one small sample.

Ecology: Reworked offshore from an ocean beach environment.

\section{Fossil record for sample taken from 221-222m depth}

Bivalvia: Paphies australis (Gmelin); one complete valve, fresh.

Paphies sp.; one small valve, fresh.

Zenatia acinaces; one complete valve, fresh.

Gastropoda: Stiracolpus sp.; one whole specimen, fresh.

Ecology: Subtidal sandy nearshore environment.

\section{Fossil record for sample taken from $223-224 m$ depth}

Bivalvia: Divaricella huttoniana (Vanatta); one complete valve, and few fragments.

Tawera spissa; one whole valve, and several fragments and juviniles, fresh.

Myadora striata (Quoy and Gaimard); one whole valve, and several

fragments, fresh.

Pleuromeris finlayi; several whole valves.

Austrovenus stutchburyi; two whole fresh valves and many large fragments.

Chlamys gemmulata (Reeve); few whole valves, and several fragments.

Nucula hartvigiana (Pkeiffer); many whole valves, show muscle scars.

Zenatia acinaces; some small fragments.

Barytellina crassidens (Marwick); broken but in tact valve.

Cellana sp.; one small valve.

Gastropoda: Stiracolpus symmetricus; whole specimens and fragments.

Zeacumantis lutulentus (Kiener); some small whole specimens. 
Amalda depressa; one whole piece.

Xymene plebeius (Philippi); two whole specimens, fresh.

Zethalia zelandica (Hombron and Jacquiout); several whole pieces, shiny.

Stiracolpus sp.; whole pieces and fragments.

Aeneator sp.; One broken specimen.

Micrelenchus dilatatus (Sowerby); one shell.

Cominella nassoides (Reeve); one whole fresh shell.

Buccinulum sp.; one almost whole piece.

Ecology: Could represent a range of shoreface-shelf environments. Most probably shallow water offshore from a sandy-bottomed wave dominated coastline.

\section{Fossil record for sample taken from 228-229m depth}

Bivalvia: Austrovenus stutchburyi; several large fragments, abraded.

Ecology: Reworked from a sub-tidal shallow marine environment.

\section{Fossil record for sample taken from 241-242m depth}

Bivalvia: Tiostrea chilensis lutaria; several pieces, abraded.

Ecology: Indeterminable, possible reworked.

\section{Fossil record for sample taken from 244-245m depth}

Bivalvia: Austrovenus stutchburyi; some large fragments, abraded.

Chlamys gemmulata; sparse whole valves, brittle.

Nucula hartvigiana; few valve fragments.

Gastropoda: Amalda depressa; one complete and almost complete piece, fresh.

Stiracolpus symmetricus; several whole pieces and fragments.

Zethalia zelandica; one spire, fresh and shiny. 
Stiracolpus sp.; several whole specimens.

Ecology: Reworked offshore from a sub-tidal nearshore environment.

\section{Fossil record for sample taken from 247-248m depth}

Bivalvia: Chlamys gemmulata; several whole valves, brittle.

Several unidentifiable shell fragments

Ploychaeta: Polychaete worm tubes: abundant, 5-10mm parallel beds.

Ecology: Shallow marine environment beyond the low tide zone on the inner shelf in $>30 \mathrm{~m}$ water depth.

\section{Fossil record for sample taken from $248-249 \mathrm{~m}$ depth}

Bivalvia: Chlamys gemmulata; whole valves bedded in mud

Ploychaeta: Polychaete worm tubes: abundant, 5-10mm thick parallel beds.

Ecology: Shallow marine environment beyond the low tide zone on the inner shelf in $>30 \mathrm{~m}$ water depth.

\section{Fossil record for sample taken from 261.5-262.5m depth}

Bivalvia: Austrovenus stutchburyi; several fragments, fresh.

Gastropoda: Amalda depressa; one whole specimen, fresh.

Ecology: Shoreface sub-tidal sandy environment.

\section{Fossil record for sample taken from $263-264 m$ depth}


Bivalvia: Austrovenus stutchburyi; one large fragment and hinge.

Ecology: Shallow marine intertidal-subtidal environment.

Fossil record for sample taken from 276-277m depth

Bivalvia: Austrovenus stutchburyi; several fragments.

Gastropoda: Stiracolpus sp.; several whole specimens, fresh.

Ecology: Shoreface sub-tidal sandy environment. 


\section{Molluscan Taxonomy}

\begin{tabular}{|c|c|c|}
\hline Species & Age range & Citation \\
\hline Austrovenus stutchburyi (Gray) & Wo-recent & Beu and Maxwell (1990), Pl. $41 \mathrm{a}, \mathrm{b}$ \\
\hline $\begin{array}{l}\text { Tiostrea chilensis lutaria } \\
\text { (Hutton) }\end{array}$ & Tk-recent & Beu and Maxwell (1990), Pl. 44i \\
\hline Pleuromeris finlayi (Powell) & Wm?-recent & Beu and Maxwell (1990), Pg. 398 \\
\hline Amalda depressa (Sowerby) & Wn-recent & Beu and Maxwell (1990), Pg. 416 \\
\hline Tawera spissa (Deshayes) & Wc-recent & Beu and Maxwell (1990), Pl. 41g \\
\hline $\begin{array}{l}\text { Zenatia acinaces (Quoy and } \\
\text { Gaimard) }\end{array}$ & Tt-recent & Beu and Maxwell (1990), Pl. 35d,h \\
\hline $\begin{array}{l}\text { Stiracolpus symmetricus } \\
\text { (Hutton) }\end{array}$ & Wn-recent & Beu and Maxwell (1990), Pg. 407 \\
\hline $\begin{array}{l}\text { Tanea zelandica (Quoy and } \\
\text { Gaimard) }\end{array}$ & Wn-recent & Beu and Maxwell (1990), Pl. 470 \\
\hline Paphies australis (Gmelin) & Wn-recent & Beu and Maxwell (1990), Pg. 399 \\
\hline $\begin{array}{l}\text { Divaricella huttoniana } \\
\text { (Vanatta) }\end{array}$ & Ab-recent & Beu and Maxwell (1990), Pl. 46b \\
\hline $\begin{array}{l}\text { Myadora striata (Quoy and } \\
\text { Gaimard) }\end{array}$ & Wn-recent & Beu and Maxwell (1990), Pl. $41 \mathrm{k}, \mathrm{m}$ \\
\hline Chlamys gemmulata (Reeve) & Wn-recent & Beu and Maxwell (1990), Pl. 44j,k \\
\hline Nucula hartvigiana (Pkeiffer) & Wn-recent & Beu and Maxwell (1990), Pg. 392 \\
\hline $\begin{array}{l}\text { Barytellina crassidens } \\
\text { (Marwick) }\end{array}$ & $\mathrm{Wp}-\mathrm{Wq}$ & Beu and Maxwell (1990), Pl. 4le,f \\
\hline Zeacumantis lutulentus (Keiner) & Wn-recent & Beu and Maxwell (1990), Pg. 406 \\
\hline Xymene plebeius (Philippi) & Wc-recent & Beu and Maxwell (1990), Pl. 48e \\
\hline $\begin{array}{l}\text { Zethalia zelandica (Hombron } \\
\text { and Jacquiout) }\end{array}$ & Wn-recent & Beu and Maxwell (1990), Pl. 47l,p \\
\hline $\begin{array}{l}\text { Micrelenchus dilatatus } \\
\text { (Sowerby) }\end{array}$ & Wn-recent & Beu and Maxwell (1990), Pg. 403 \\
\hline Cominella nassoides (Reeve) & Wn-recent & Beu and Maxwell (1990), Pl. 42d \\
\hline
\end{tabular}




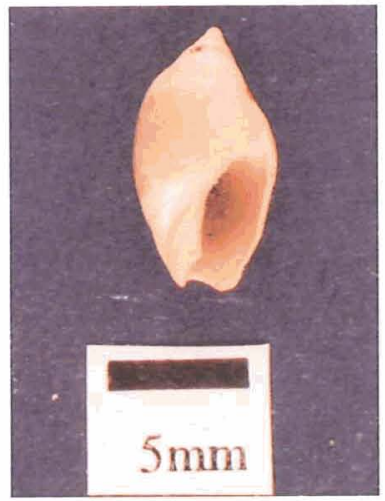

Amalda depressa

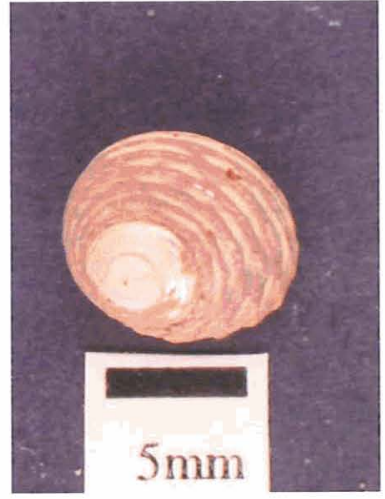

Micrelenchus dilatatus

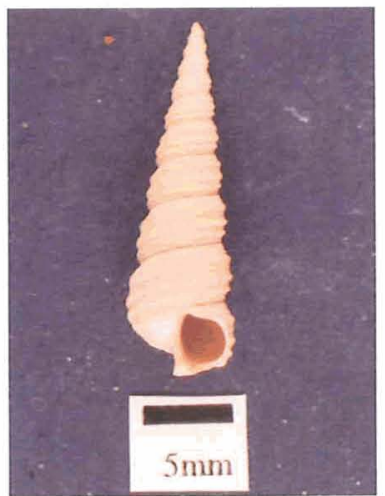

Stiracolpus sp.

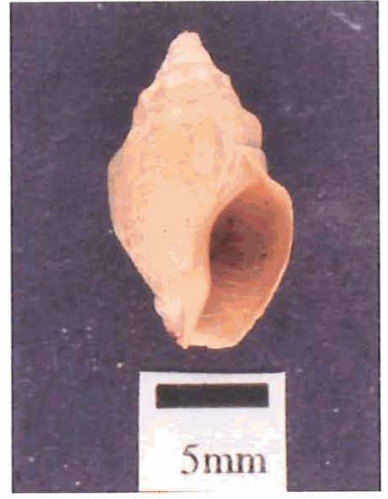

Cominella nassoides

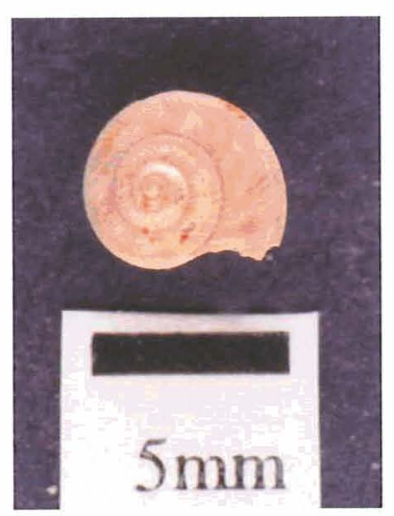

Zethlalia zelandica

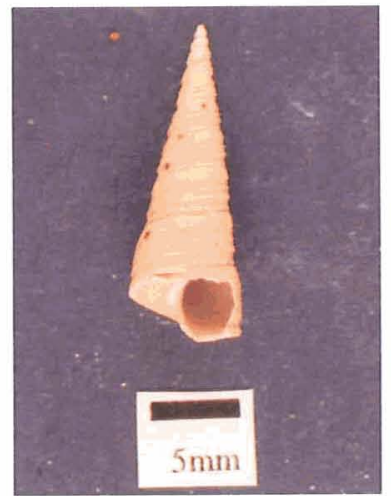

Zeacolpus symmetricus

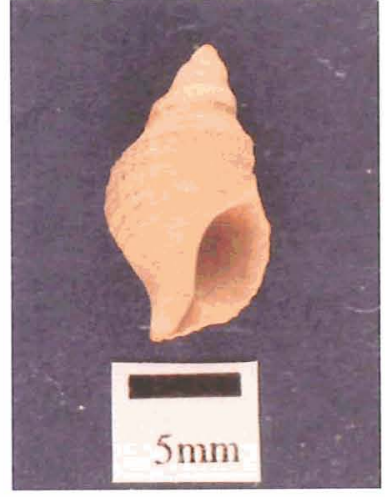

Xymene plebeius

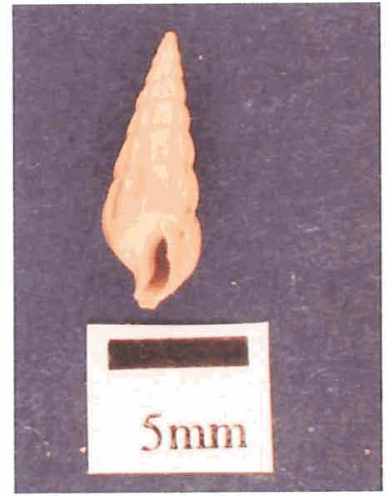

Zeacumantus lutulentus

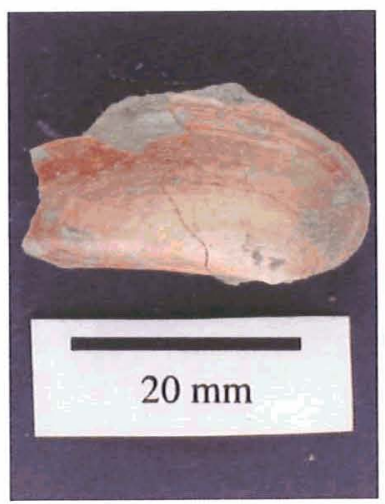

Ventral only

Paphies australis

Appendix B3: Photographs of identifiable molluscs found in the Levin borehole. 


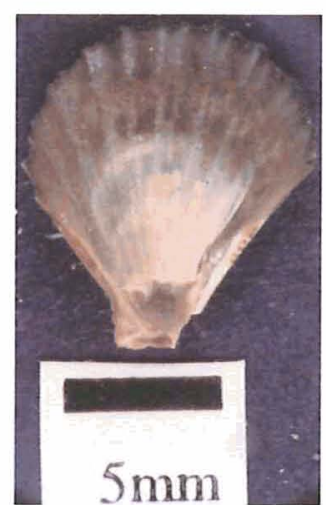

Dorsal

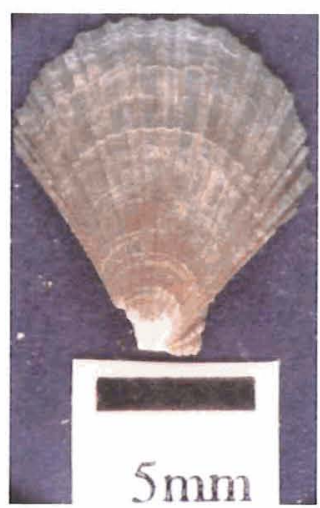

Ventral

Chlamys gemmulata

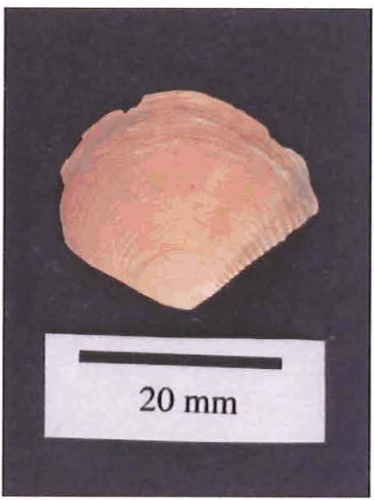

Dorsal

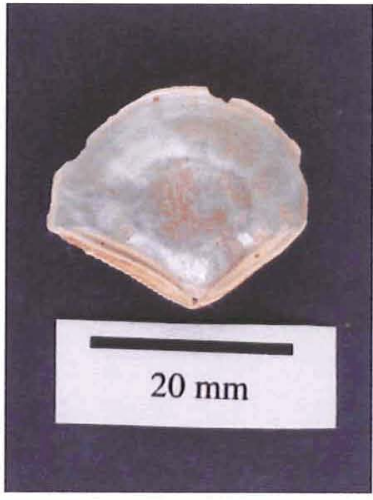

Ventral

Myadora striata

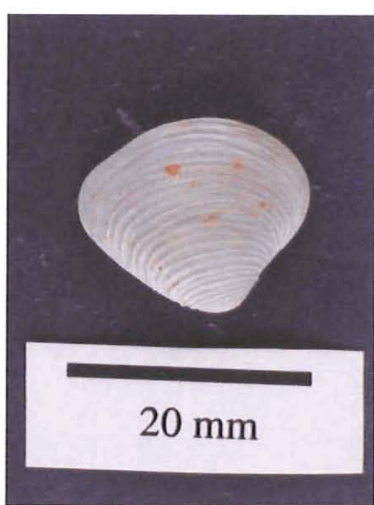

Dorsal

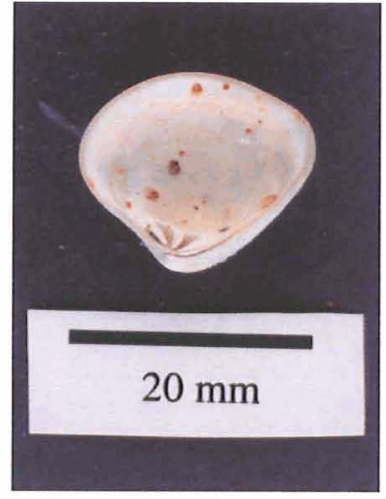

Ventral

Tawera spissa

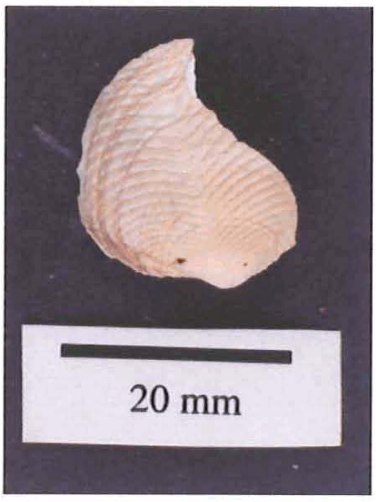

Dorsal

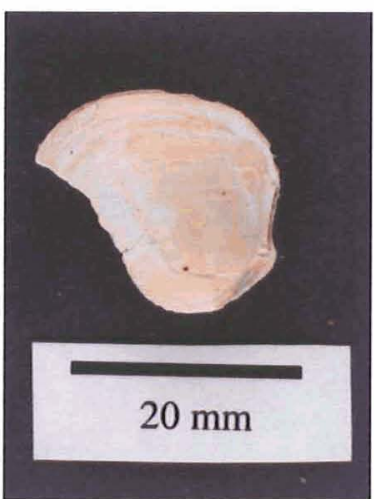

Ventral

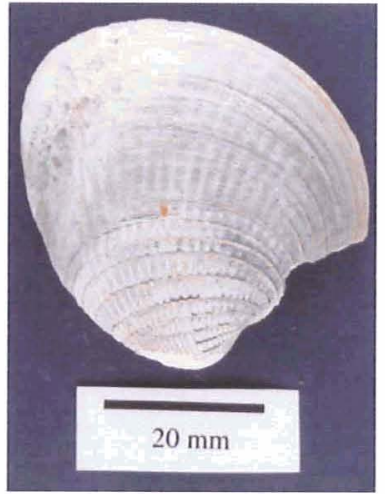

Dorsal

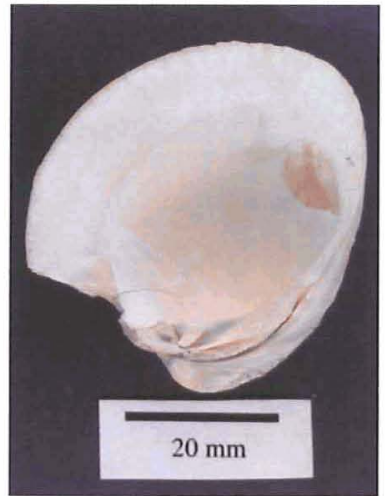

Ventral

Austrovenus stutchburyi

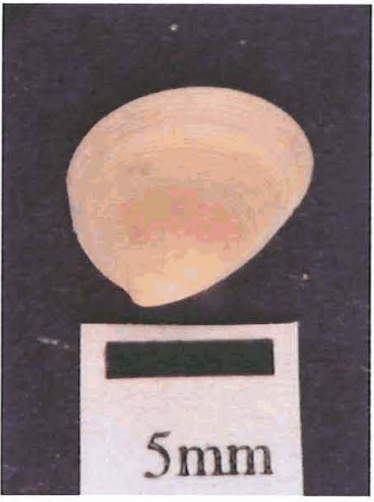

Dorsal

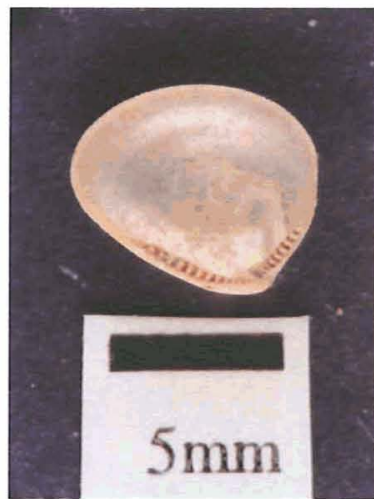

Ventral

Nucula hartvigiana

Appendix B3 continued.. 


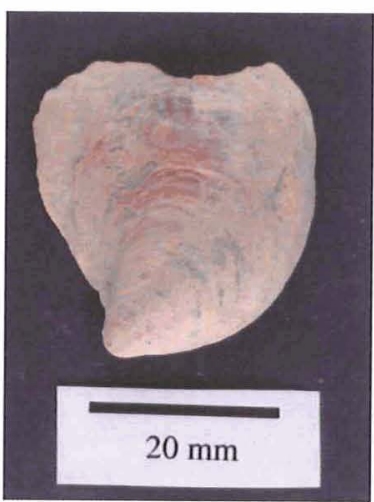

Dorsal

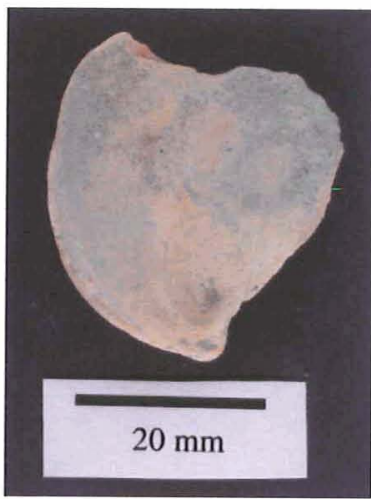

Ventral

Tiostrea chilensis lutaria

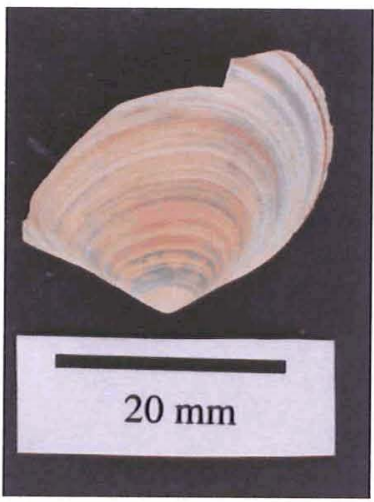

Dorsal

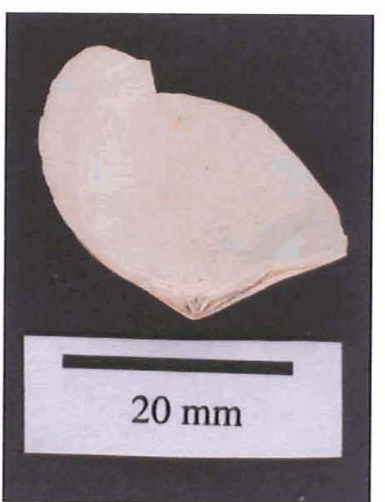

Ventral

Barytellina crassidens

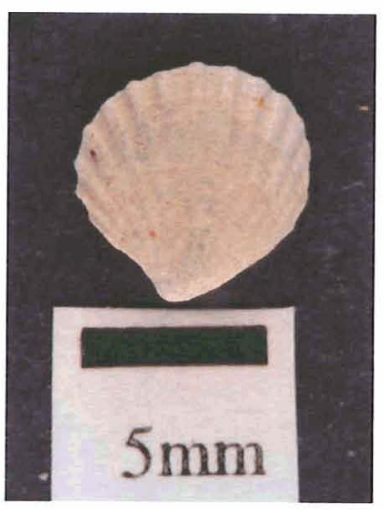

Dorsal

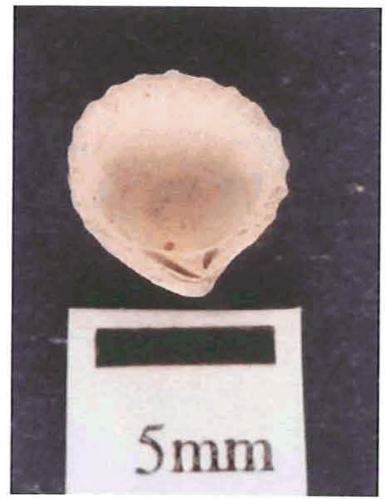

Ventral

Pleuromeris finlayi

Appendix B3 continued... 
Appendix C:

\section{GRAINSIZE ANALYSIS AND DATA}

\section{Processing of samples}

Samples were analysed for grainsize composition at Victoria University using the methods outlined by Barrett et al. (2000). Between 30 and 40g of sample was oven dried at $40^{\circ} \mathrm{c}$ for 24 hours. Indurated samples were crushed gently between two wooden blocks to disaggregate large clumps; it was ensured no grains were broken during this process. A small sample was tested using 10\% Hydrochloric Acid for carbonaceous material. If effervescence occurred, the entire sample was treated with acid till all carbonate was removed and then washed three times using distilled water to remove excess acid.

Dry samples were then mixed with distilled water and $0.1 \%$ calgon solution and disaggregated in an ultrasonic tank for 30 minutes. A micro-sample was checked for material not fully disaggregated. If aggregates were found, then treatment continued for another 30 minutes. The sample was then wet-sieved through a 63 micron monolen cloth to separate out sand and mud fractions. The fine fraction was placed in a centrifuge and rotated at 5000 RPM for 10 minutes to remove calgon solution, Both fractions were dried and weighed ready for size analysis.

\section{Analysis of the mud fraction $(<0.063 \mathrm{~mm})$}

Between 1 and 2 grams of the mud fraction was mixed with $40 \mathrm{ml} 0.1 \%$ calgon solution and analysed using x-ray diffraction in Sedigraph 5100 machine at Victoria University. Results were computed as mass frequency percents for half phi intervals between 4.0$10.0 \varnothing$. Actual weight proportions for each phi class were determined by multiplying its mass frequency percent with the total weight of fine fraction gained from wet-sieving.

Analysis of the sand fraction $(0.063-2 \mathrm{~mm})$ 
The sand fraction $(0.063-2 \mathrm{~mm})$ was dry-sieved at half phi intervals between $-2.0 \varnothing$ and $5.0 \varnothing$ on a Fritsch shaker for 18 minutes. Because wet-sieving invariably retains some coarse silt, dry sieving intervals were extended to catch $4.5 \varnothing$ and $5.0 \varnothing$ fractions. The weight of grains retained in each half phi interval was recorded and were combined with the Sedigraph results.

\section{Errors}

The greatest potential for errors involved sample loss or gain. This was most likely to occur during the sieving (wet and dry) stages of analysis. For example during wet sieving, splashes may cause grains to be lost. Alternatively, some grains maybe retained within the dry sieves, hence final totals were often less then the initial totals. However, sample losses or gains were never exceeded $4 \%$ and are considered minor.

Analytical errors may also have arisen during sieving as this doesn't take into account grain shape. Therefore it was assumed all grains were mainly spherical particles and is representative of their associated phi interval.

\section{Grainsize data analysis}

Grainsize mass frequency data was entered into VUWSIZE computer program contained in the Sedimentology Laboratory at Victoria University. Phi classes, graphic and moment measures, class limits-mid points were calculated for each half phi interval between $-2 \varnothing$ to $10 \varnothing$. Histograms were constructed to visually display grainsize results. 


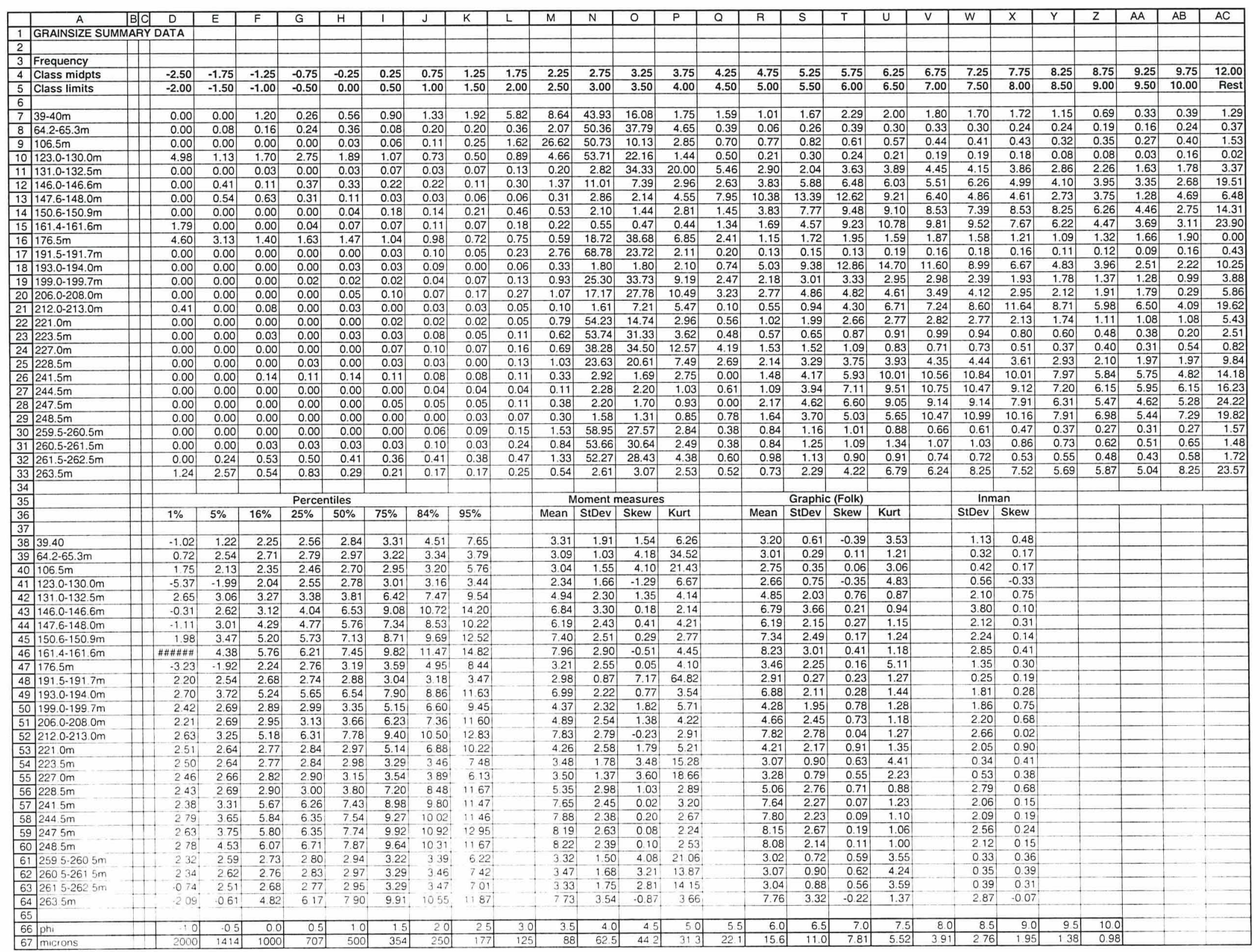


GRAIN SIZE FREQUENCY PLOTS AND SUMMARY DATA

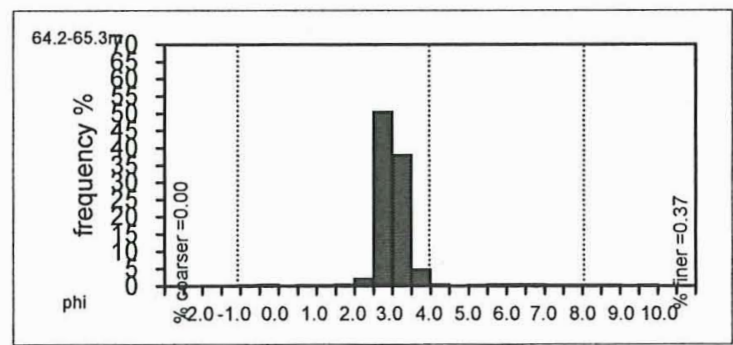

$64.2-65.3 \mathrm{~m}$

\begin{tabular}{|l|r|}
\hline Gravel & 0.24 \\
\hline Sand & 96.30 \\
\hline Silt & 2.26 \\
\hline Clay & 1.20 \\
\hline Mud & 3.46 \\
\hline
\end{tabular}

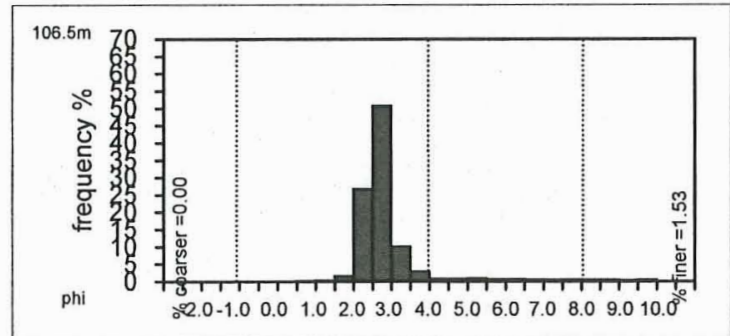

$106-107 \mathrm{~m}$

\begin{tabular}{|l|r|}
\hline Gravel & 0.00 \\
\hline Sand & 92.39 \\
\hline Silt & 4.75 \\
\hline Clay & 2.86 \\
\hline Mud & 7.61 \\
\hline
\end{tabular}

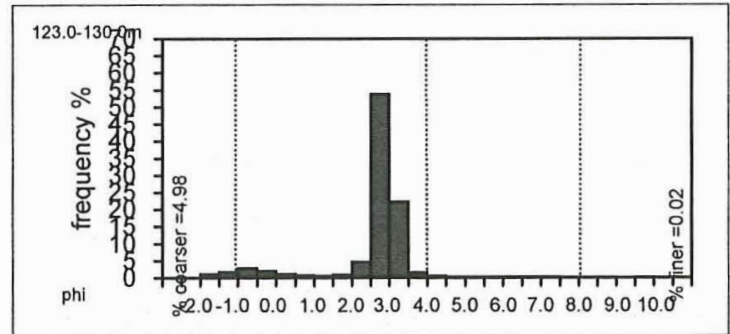

\section{0-130.0m}

\begin{tabular}{|l|r|}
\hline Gravel & 7.81 \\
\hline Sand & 89.81 \\
\hline Silt & 2.02 \\
\hline Clay & 0.37 \\
\hline Mud & 2.38 \\
\hline
\end{tabular}

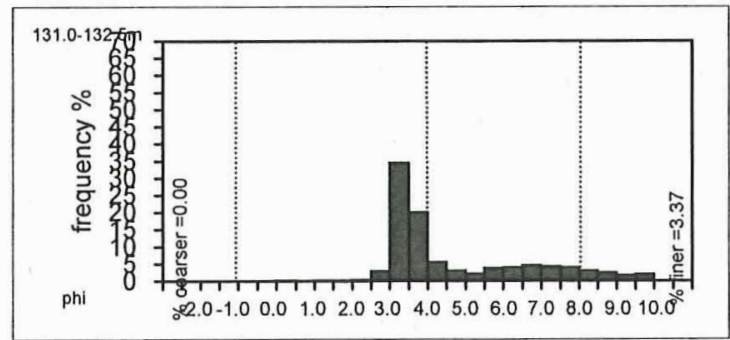

\section{$131.0-132.5 \mathrm{~m}$}

\begin{tabular}{|l|r|}
\hline Gravel & 0.03 \\
\hline Sand & 57.68 \\
\hline Silt & 30.38 \\
\hline Clay & 11.90 \\
\hline Mud & 42.29 \\
\hline
\end{tabular}

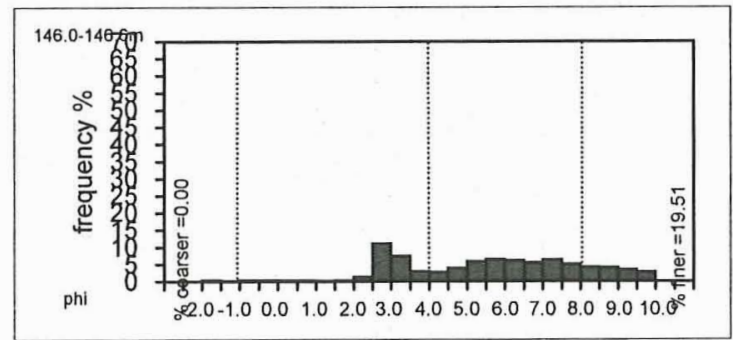

146.0-146.6m

\begin{tabular}{|l|r|}
\hline Gravel & 0.52 \\
\hline Sand & 24.28 \\
\hline Silt & 41.62 \\
\hline Clay & 33.59 \\
\hline Mud & 75.20 \\
\hline
\end{tabular}




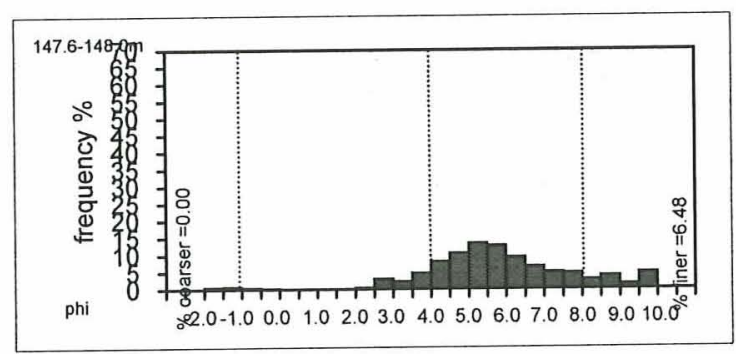

\section{6-148.0m}

\begin{tabular}{|l|r|}
\hline Gravel & 1.17 \\
\hline Sand & 10.47 \\
\hline Silt & 69.42 \\
\hline Clay & 18.93 \\
\hline Mud & 88.36 \\
\hline
\end{tabular}

\section{$150.6-150.9 m$}
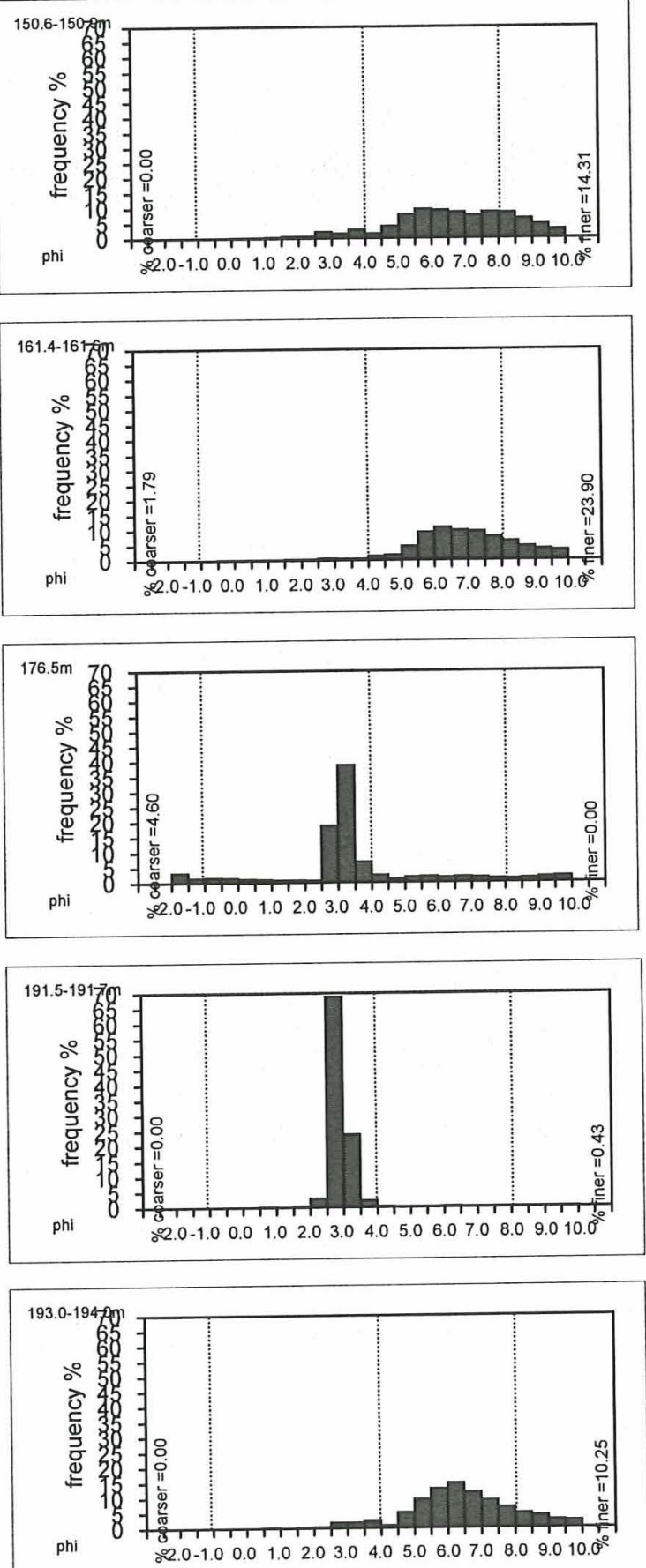

\begin{tabular}{|l|r|}
\hline Gravel & 0.00 \\
\hline Sand & 7.89 \\
\hline Silt & 56.09 \\
\hline Clay & 36.02 \\
\hline Mud & 92.11 \\
\hline
\end{tabular}

161.4-161.6m

\begin{tabular}{|l|r|}
\hline Gravel & 1.79 \\
\hline Sand & 2.23 \\
\hline Silt & 54.60 \\
\hline Clay & 41.38 \\
\hline Mud & 95.98 \\
\hline
\end{tabular}

\section{6-177m}

\begin{tabular}{|l|r|}
\hline Gravel & 9.13 \\
\hline Sand & 71.43 \\
\hline Silt & 13.47 \\
\hline Clay & 5.97 \\
\hline Mud & 19.44 \\
\hline
\end{tabular}

191.5-191.7m

\begin{tabular}{|l|r|}
\hline Gravel & 0.00 \\
\hline Sand & 97.79 \\
\hline Silt & 1.29 \\
\hline Clay & 0.92 \\
\hline Mud & 2.21 \\
\hline
\end{tabular}

193.0-194.0m

\begin{tabular}{|l|r|}
\hline Gravel & 0.00 \\
\hline Sand & 6.25 \\
\hline Silt & 69.97 \\
\hline Clay & 23.79 \\
\hline Mud & 93.75 \\
\hline
\end{tabular}




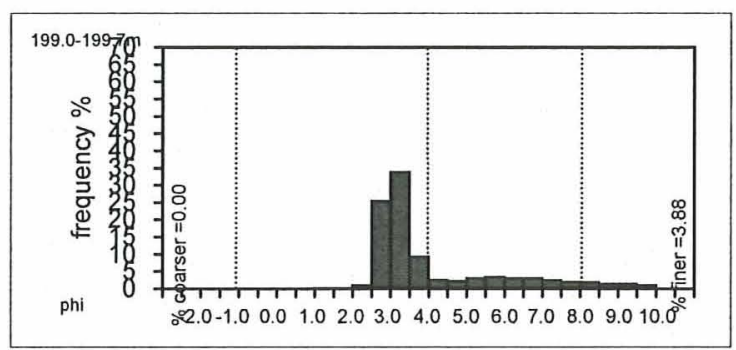

199.0-199.7m

\begin{tabular}{|l|r|}
\hline Gravel & 0.00 \\
\hline Sand & 69.46 \\
\hline Silt & 21.22 \\
\hline Clay & 9.31 \\
\hline Mud & 30.54 \\
\hline
\end{tabular}

206.0-208.0m

\begin{tabular}{|l|r|}
\hline Gravel & 0.00 \\
\hline Sand & 57.17 \\
\hline Silt & 30.86 \\
\hline Clay & 11.97 \\
\hline Mud & 42.83 \\
\hline
\end{tabular}

\section{0-213.0m}

\begin{tabular}{|l|r|}
\hline Gravel & 0.49 \\
\hline Sand & 14.52 \\
\hline Silt & 40.09 \\
\hline Clay & 44.89 \\
\hline Mud & 84.98 \\
\hline
\end{tabular}

\section{1-222m}

\begin{tabular}{|l|r|}
\hline Gravel & 0.00 \\
\hline Sand & 72.84 \\
\hline Silt & 16.72 \\
\hline Clay & 10.44 \\
\hline Mud & 27.26 \\
\hline
\end{tabular}

\section{3-224m}

\begin{tabular}{|l|r|}
\hline Gravel & 0.03 \\
\hline Sand & 89.60 \\
\hline Silt & 6.20 \\
\hline Clay & 4.17 \\
\hline Mud & 10.37 \\
\hline
\end{tabular}

\section{7-228m}

\begin{tabular}{|l|r|}
\hline Gravel & 0.00 \\
\hline Sand & 86.44 \\
\hline Silt & 11.11 \\
\hline Clay & 2.45 \\
\hline Mud & 13.56 \\
\hline
\end{tabular}




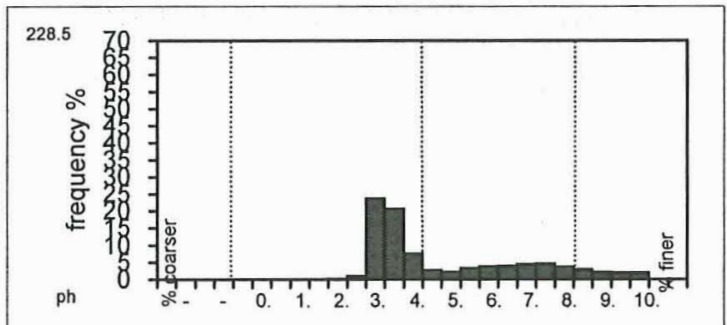

228-229m

\begin{tabular}{|l|r|}
\hline Gravel & 0.00 \\
\hline Sand & 52.99 \\
\hline Silt & 28.20 \\
\hline Clay & 18.80 \\
\hline Mud & 47.01 \\
\hline
\end{tabular}

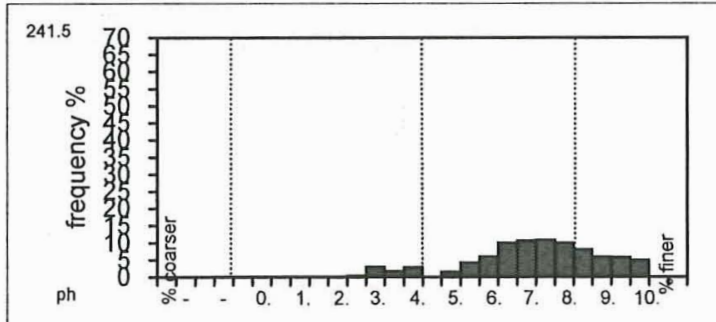

\section{1-242m}

\begin{tabular}{|l|r|}
\hline Gravel & 0.14 \\
\hline Sand & 8.32 \\
\hline Silt & 53.00 \\
\hline Clay & 38.55 \\
\hline Mud & 91.55 \\
\hline
\end{tabular}

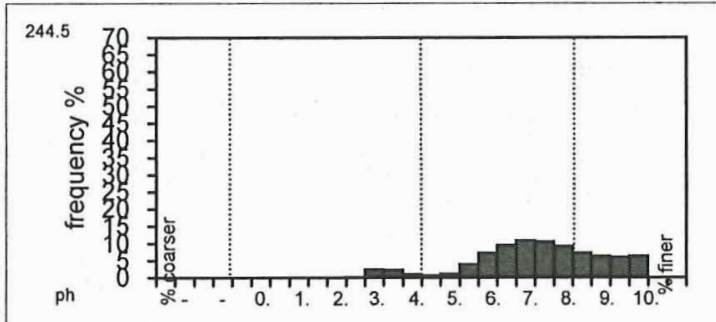

244-245m

\begin{tabular}{|l|r|}
\hline Gravel & 0.00 \\
\hline Sand & 5.73 \\
\hline Silt & 52.60 \\
\hline Clay & 41.67 \\
\hline Mud & 94.27 \\
\hline
\end{tabular}

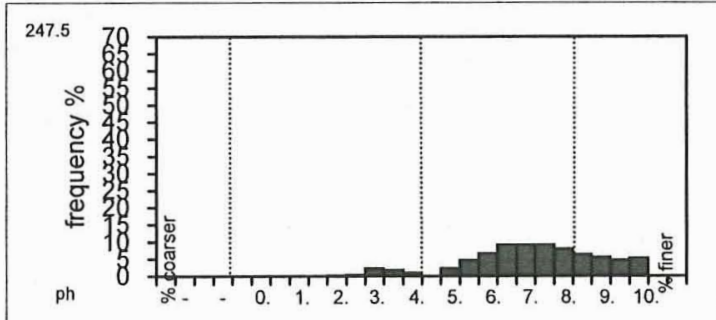

247-248m

\begin{tabular}{|l|r|}
\hline Gravel & 0.00 \\
\hline Sand & 5.49 \\
\hline Silt & 48.62 \\
\hline Clay & 45.89 \\
\hline Mud & 94.51 \\
\hline
\end{tabular}

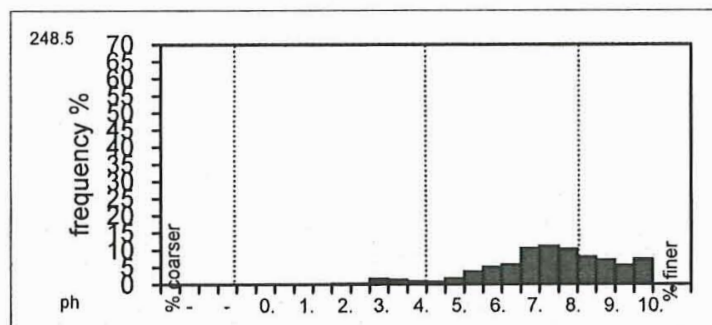

248-249m

\begin{tabular}{|l|r|}
\hline Gravel & 0.00 \\
\hline Sand & 4.14 \\
\hline Silt & 48.43 \\
\hline Clay & 47.44 \\
\hline Mud & 95.86 \\
\hline
\end{tabular}

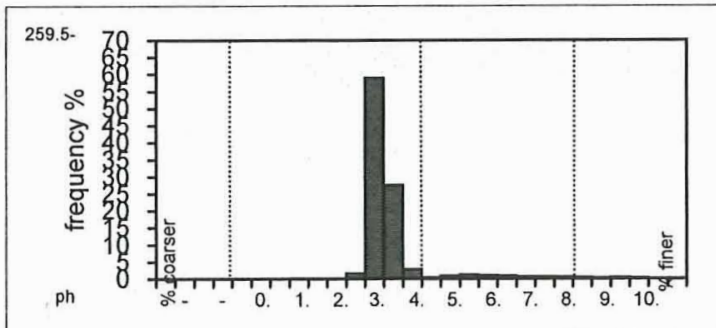

259.5-260.5m

\begin{tabular}{|l|r|}
\hline Gravel & 0.00 \\
\hline Sand & 91.20 \\
\hline Silt & 6.01 \\
\hline Clay & 2.79 \\
\hline Mud & 8.80 \\
\hline
\end{tabular}




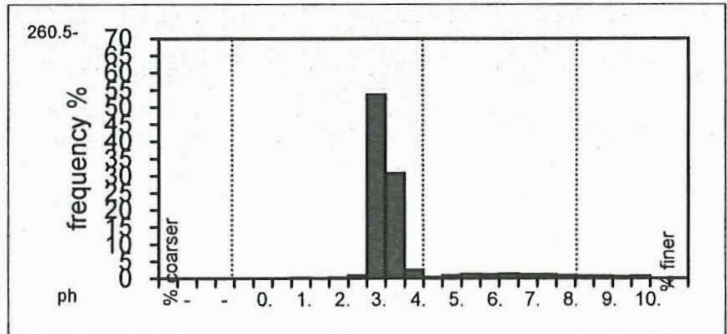

260.5-261.5m

\begin{tabular}{|l|r|}
\hline Gravel & 0.03 \\
\hline Sand & 88.1 \\
\hline Silt & 7.88 \\
\hline Clay & 3.99 \\
\hline Mud & 11.86 \\
\hline
\end{tabular}

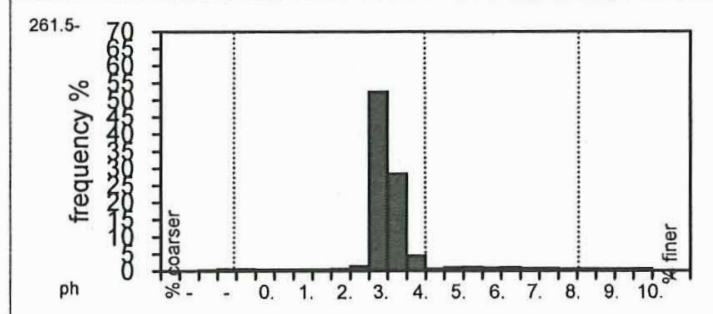

261.5-262.5m

\begin{tabular}{|l|r|}
\hline Gravel & 0.77 \\
\hline Sand & 88.95 \\
\hline Silt & 6.51 \\
\hline Clay & 3.77 \\
\hline Mud & 10.28 \\
\hline
\end{tabular}

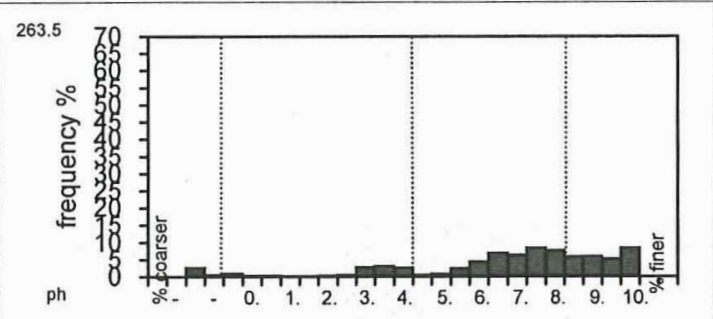

263-264m

\begin{tabular}{|l|r|}
\hline Gravel & 4.36 \\
\hline Sand & 10.66 \\
\hline Silt & 36.56 \\
\hline Clay & 48.42 \\
\hline Mud & 84.98 \\
\hline
\end{tabular}


Appendix D:

MICROFOSSIL ANAL YSIS AND DATA

\section{Processing of foraminifera}

Samples that returned a positive test for carbonate after treatment with hydrochloric acid were processed for foraminifera. A small portion (c. $20 \mathrm{~g}$ ) of sediment from these were mixed with sodium bicarbonate and boiling water, to release calcareous fossils from the matrix, and then sieved through a $2 \mathrm{~mm}$ metal sieve and a 63 micron nylon mesh sieve. Foraminifera were picked from the sand fraction caught in the 63 micron sieve after it was oven dried at $40^{\circ} \mathrm{c}$ for 24 hours.

\section{Cluster analysis}

19 variables and 80 cases were analysed using un-weighted pair group cluster analysis using Bray-Curtis distance matrix. Clusters were calculated using the MVSP version 3.1 computer programme (Kovach, 2003) (results below).

$\begin{array}{lllll}\text { Node } & \text { Group 1 } & \text { Group 2 } & \text { Dissimil. } & \text { In group } \\ 1 & 247.5 & 248.5 & 0.220 & 2 \\ 2 & 193-194 & 206-208 & 0.240 & 2 \\ 3 & 221 & 227 & 0.240 & 2 \\ 4 & 176.5 & 223.5 & 0.260 & 2 \\ 5 & 191.5-191.7 & 199.5-199.7 & 0.260 & 2 \\ 6 & \text { Node 5 } & \text { Node 3 } & 0.270 & 4 \\ 7 & 259.5-260.5 & 261.5-262.5 & 0.321 & 2 \\ 8 & \text { Node 6 } & \text { 260.5-261.5 } & 0.333 & 5 \\ 9 & 244.5 & \text { Node 1 } & 0.335 & 3 \\ 10 & \text { Node } 8 & \text { Node } 2 & 0.369 & 7 \\ 11 & 228.5 & 277.3 & 0.390 & 2 \\ 12 & \text { Node } 10 & \text { Node } 7 & 0.411 & 9 \\ 13 & 131.5-132.0 & \text { Node } 12 & 0.455 & 10 \\ 14 & \text { Node } 13 & \text { Node } 4 & 0.469 & 12 \\ 15 & 212-213 & 241.5 & 0.470 & 2 \\ 16 & \text { Node } 15 & \text { Node } 9 & 0.573 & 5 \\ 17 & \text { Node } 14 & \text { Node } 11 & 0.608 & 14 \\ 18 & \text { Node } 17 & \text { Node } 16 & 0.745 & 19\end{array}$




\section{Foraminiferal Taxonomy}

\begin{tabular}{|c|c|c|}
\hline Species & Age range & Citation \\
\hline Ammonia parkinsoniana (Finlay) & Tk-recent & $\begin{array}{l}\text { Hayward et al. (1999), } \\
\text { Pl. 16, Figs. 7-9 }\end{array}$ \\
\hline Elphidium advenum (Cushman) & Ar-recent & $\begin{array}{l}\text { Hayward et al. }(1997 a) \text {, } \\
\text { Pl. 2, Figs. 14-18 }\end{array}$ \\
\hline $\begin{array}{l}\text { Elphidium advenum f. maorium } \\
\text { (Hayward n.ssp.) }\end{array}$ & Ar-recent & $\begin{array}{l}\text { Hayward et al. (1997a), } \\
\text { Pl. 5, Figs. 13-14 }\end{array}$ \\
\hline Elphidium crispum (Linne) & Ar-recent & $\begin{array}{l}\text { Hayward et al. (1997a), } \\
\text { Pl. 8, Figs. 3-9 }\end{array}$ \\
\hline $\begin{array}{l}\text { Elphidium excavatum } f \text {. clavatum } \\
\text { (Cushman) }\end{array}$ & Po-recent & $\begin{array}{l}\text { Hayward et al. (1997a), } \\
\text { Pl. 9, Figs. 3-5 }\end{array}$ \\
\hline $\begin{array}{l}\text { Elphidium excavatum } f \text {. williamsoni } \\
\text { (Haynes) }\end{array}$ & Wn-recent & $\begin{array}{l}\text { Hayward et al. (1997a), } \\
\text { Pl. 10, Figs. 11-12 }\end{array}$ \\
\hline Elphidium charlottensis (Vella) & Lwh-recent & $\begin{array}{l}\text { Hayward et al. (1997a), } \\
\text { Pl. 6, Figs. 13-16 }\end{array}$ \\
\hline Notorotalia finlayi (Vella) & Wp-recent & $\begin{array}{l}\text { Hayward et al. (1999), } \\
\text { Pl. 16, Figs. 19-21 }\end{array}$ \\
\hline Notorotalia inornata (Vella) & Wm-recent & $\begin{array}{l}\text { Hayward et al. (1999), } \\
\text { Pl. 16, Figs. 22-24 }\end{array}$ \\
\hline $\begin{array}{l}\text { Haynesina depressula (Walker and } \\
\text { Jacob) }\end{array}$ & Lwh-recent & $\begin{array}{l}\text { Hayward et al. (1997a), } \\
\text { Pl. 19, Figs. 4-7 }\end{array}$ \\
\hline Nonionellina flemingi (Vella) & Sw-recent & $\begin{array}{l}\text { Hayward et al. (1999), } \\
\text { Pl. 15, Figs. 14-15 }\end{array}$ \\
\hline Zeaflorilus parri (Cushman) & Sl-recent & $\begin{array}{l}\text { Hayward et al. (1999), } \\
\text { Pl. 15, Figs. 18-20 }\end{array}$ \\
\hline Rosalina bradyi (Cushman) & Sw-recent & $\begin{array}{l}\text { Hayward et al. (1999), } \\
\text { Pl. 11, Fig. 1-3 }\end{array}$ \\
\hline Discorbinella bertheloti (d'Orbigny) & Ld-recent & $\begin{array}{l}\text { Hayward et al. (1999), } \\
\text { Pl. 14, Figs. 1-3 }\end{array}$ \\
\hline $\begin{array}{l}\text { Oolina borealis (Loeblich and } \\
\text { Tappan) }\end{array}$ & Recent & $\begin{array}{l}\text { Hayward et al. (1999), } \\
\text { Pl. 8, Fig. } 1\end{array}$ \\
\hline Quinqueloculina incisa (Vella) & Tk-recent & $\begin{array}{l}\text { Hayward et al. (1999), } \\
\text { Pl. 4, Figs. 25-26 }\end{array}$ \\
\hline $\begin{array}{l}\text { Quinqueloculina suborbicularis } \\
\text { (d'Orbigny) }\end{array}$ & Recent & $\begin{array}{l}\text { Hayward et al. (1999), } \\
\text { Pl. 5, Figs. 6-8 }\end{array}$ \\
\hline
\end{tabular}




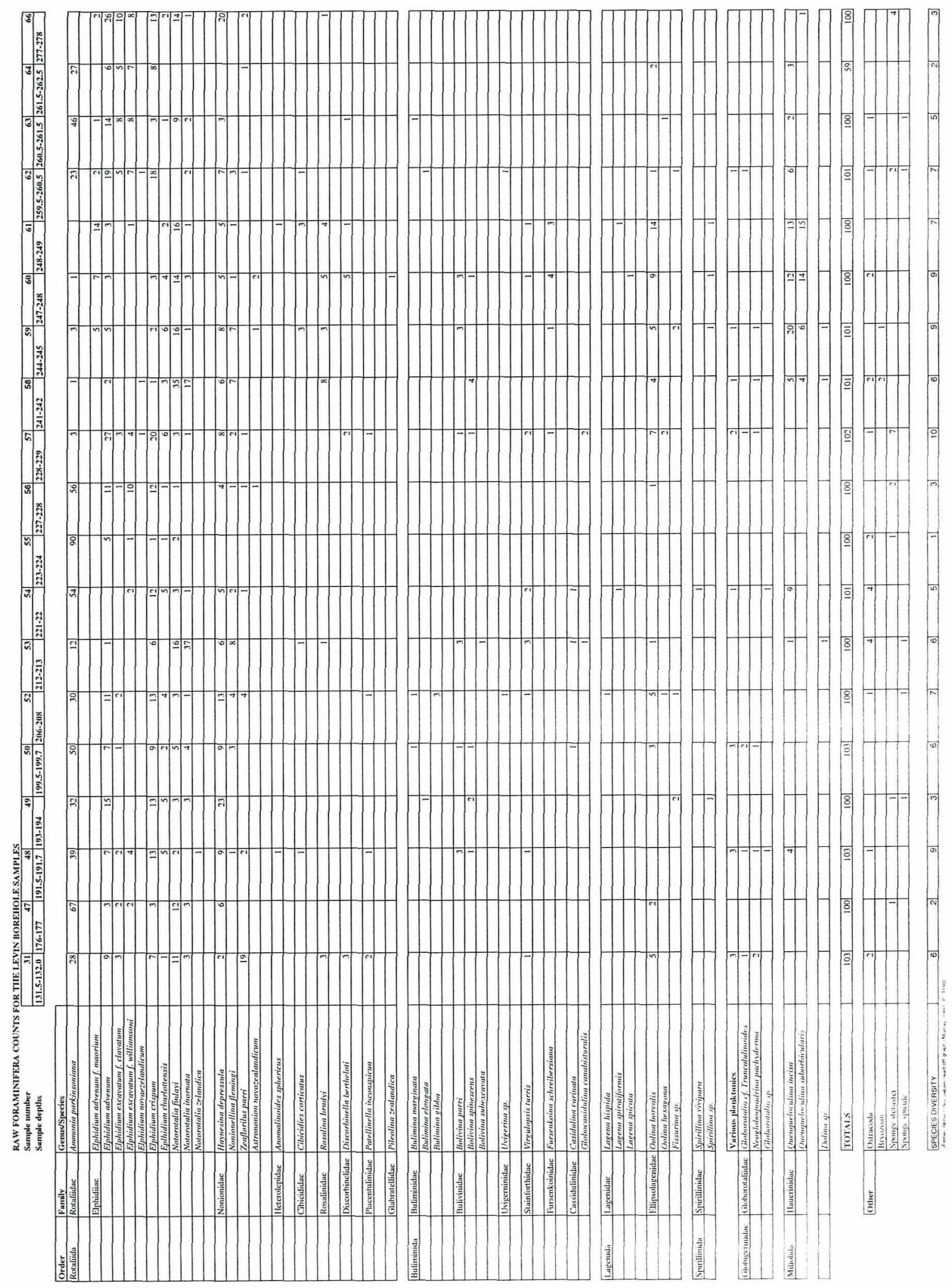




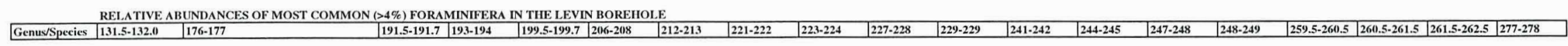

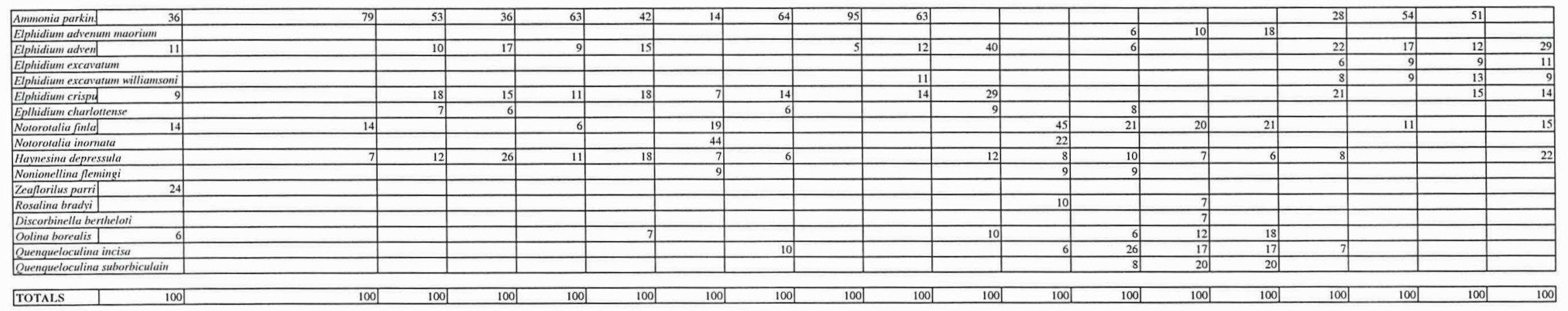
SPECIES ASSOCIATION SUMMARY

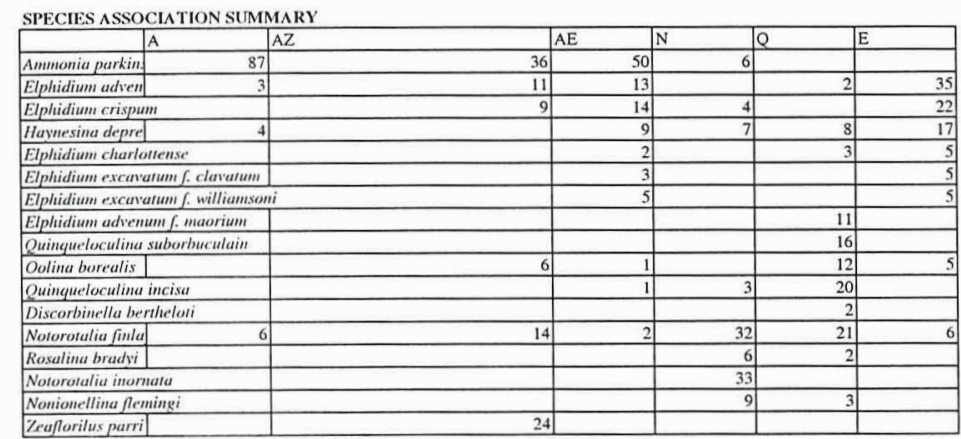




\section{Appendix E:}

\section{POLLEN ANALYSIS AND DATA}

Samples containing predominantly silt- and sand-sized particles were processed for palynomorphs according to the procedures outlined by Moore and Webb (1978). These state that extraneous matter is sequentially removed from sediment in a number of steps using chemical treatment (see below). Each chemical treatment is separated by washing with distilled water and concentrating in a centrifuge.

1) Samples were treated with a solution of $10 \%$ Potassium Hydroxide for 20 minutes at $80^{\circ} \mathrm{C}$ to neutralise the humic acids and release palynomorphs from the matrix material. Marine samples required extra treatment of $10 \%$ Hydrochloric Acid $(\mathrm{HCl})$ to remove carbonate.

2) Siliceous material was then removed by treatment with c. $10 \mathrm{ml}$ Hydroflouric Acid for 24 hours. They were then rinsed in $\mathrm{HCl}$ till all fluorosilicates were removed.

3) Samples were then dehydrated by washing with glacial acetic acid before undergoing acetolysis to remove cellulosic material. The acetolysis mixture requires $5 \mathrm{ml}$ of concentrated sulfuric acid and $45 \mathrm{ml}$ of acetic anhydride. Samples were then left for $20 \mathrm{~min}$ at $80^{\circ} \mathrm{c}$ in $6 \mathrm{ml}$ of this mixture. They were then again treated with glacial acetic acid and rinsed five times to remove all acid.

4) Palynomorphs were then concentrated by floating in a heavy liquid (sodium polytungstate) and samples were mounted onto slides in glycerine jelly. 


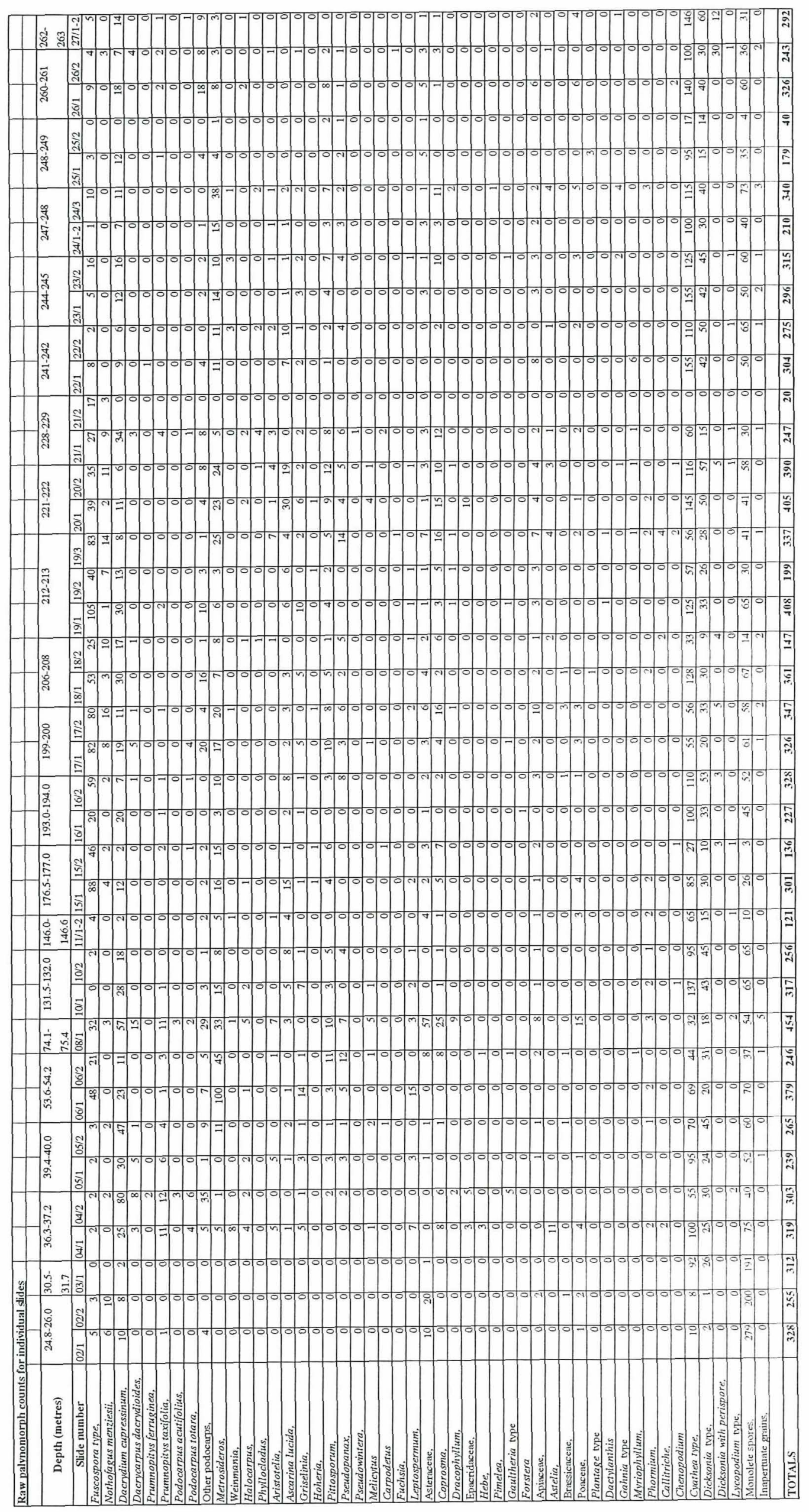



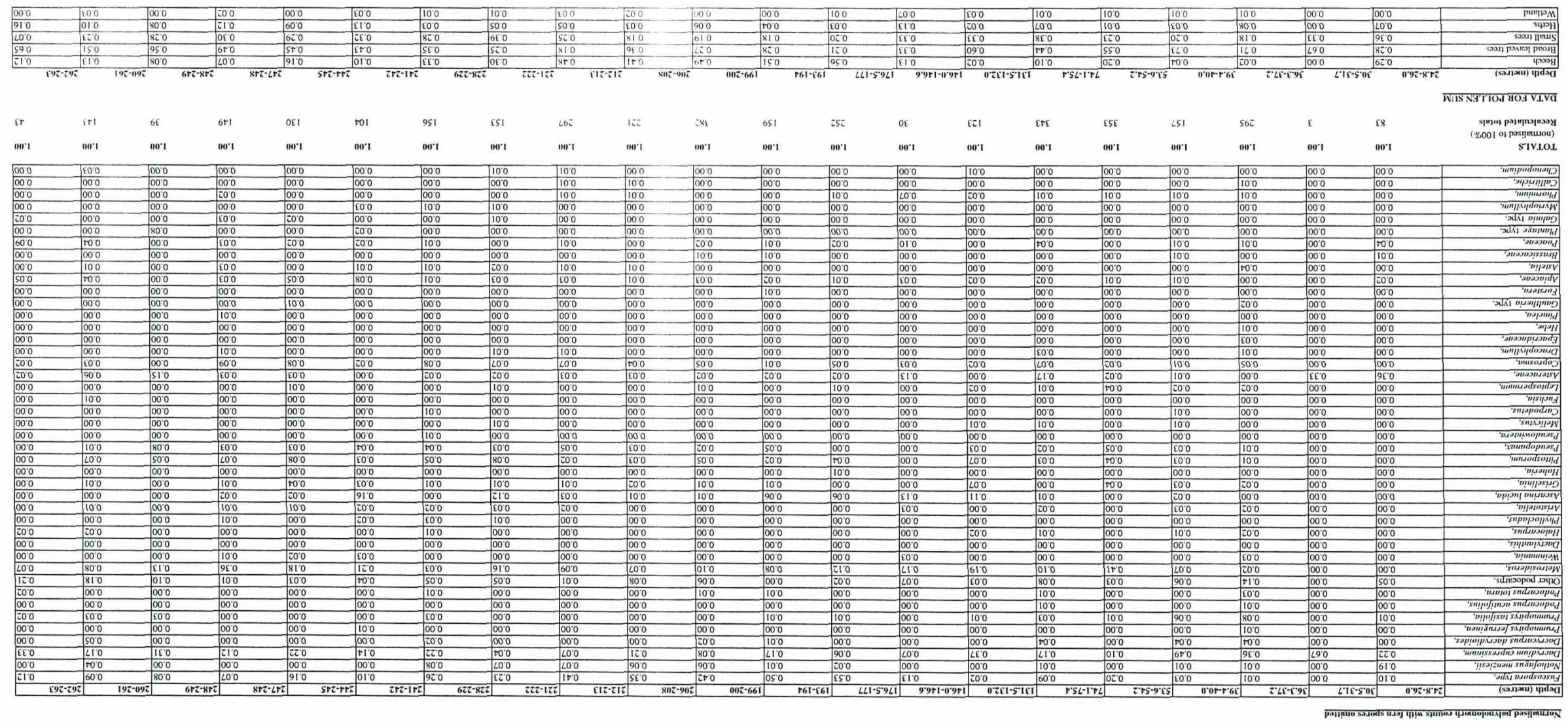


\section{Appendix $\mathbf{F}$ :}

SUMMARY OF DATES RELEVANT TO THE LEVIN BOREHOLE

\section{Radiocarbon dates}

\begin{tabular}{|c|c|c|c|c|c|}
\hline Reference & Collector & Location & Sample & Age & Significance \\
\hline NZ 80 & $\begin{array}{l}\text { M. T. Te } \\
\text { Punga }\end{array}$ & $\begin{array}{l}\text { Awahuri Dairy } \\
\text { Factory well, } \\
\text { Awahuri, } \\
\text { Manawatu. } \\
\text { Sample } 71 \mathrm{~m} \\
\text { below ground } \\
\text { level. }\end{array}$ & $\begin{array}{l}\text { Shell Austrovenus } \\
\text { stutchburyi from } \\
\text { sandy gravel bed }\end{array}$ & $>45000 \mathrm{yrs}$ & $\begin{array}{l}\text { Last interglacial } \\
\text { deposit now } \\
\text { buried to depth of } \\
71 \mathrm{~m} \text { (Te Punga, } \\
1954 \text { ). }\end{array}$ \\
\hline NZ 522 & $\begin{array}{l}\text { C. A. Fleming } \\
\& \text { T. L. Grant- } \\
\text { Taylor }\end{array}$ & $\begin{array}{l}\text { Levin- } \\
\text { Koputaroa } \\
\text { Road, } \\
\text { Horowhenua. }\end{array}$ & $\begin{array}{l}\text { Peat } 1.6 \mathrm{~m} \text { below } \\
\text { base of } \\
\text { Aokautere Ash in } \\
\text { Koputaroa dune } \\
\text { sand }\end{array}$ & $\begin{array}{l}35000 \pm 1700 \\
\text { yrs }\end{array}$ & $\begin{array}{l}\text { Dates a phase of } \\
\text { cooler climate } \\
\text { (McIntyre, 1963). }\end{array}$ \\
\hline NZ 573 & C. A. Fleming & $\begin{array}{l}\text { Lindale, Kapiti } \\
\text { Coast District. }\end{array}$ & $\begin{array}{l}\text { Pollen from } \\
\text { Carbonaceous silt } \\
\text { buried in fan } \\
\text { deposits }\end{array}$ & $\begin{array}{l}19200 \pm \\
560 \text { yrs BP }\end{array}$ & $\begin{array}{l}\text { Advance of } \\
\text { periglacial fan } \\
\text { before } 19.2 \mathrm{ka} \text { that } \\
\text { continued some } \\
\text { time afterwards } \\
\text { (Fleming, 1970). }\end{array}$ \\
\hline NZ 3085A & P. A. Hesp & $\begin{array}{l}\text { Manawatu } \\
\text { floodplain, } \\
3 \mathrm{~km} \text { SW of } \\
\text { Shannon, 0.9- } \\
1.1 \mathrm{~m} \text { above } \\
\text { mean sea level. }\end{array}$ & $\begin{array}{l}\text { Shells; in situ } \\
\text { marine bivalve } \\
\text { within intertidal } \\
\text { mud and clay }\end{array}$ & $\begin{array}{l}6150 \pm 60 y r s \\
\text { BP }\end{array}$ & $\begin{array}{l}\text { Dates the post } \\
\text { glacial estuary in } \\
\text { Lower Manawatu } \\
\text { Valley (Hesp and } \\
\text { Shepherd, 1978). }\end{array}$ \\
\hline NZ 3085B & P. A. Hesp & $\begin{array}{l}\text { Manawatu } \\
\text { floodplain, } \\
3 \mathrm{~km} \text { SW of } \\
\text { Shannon, 0.9- } \\
1.1 \mathrm{~m} \text { above } \\
\text { mean sea level. }\end{array}$ & $\begin{array}{l}\text { Shells; in situ } \\
\text { marine bivalve } \\
\text { within intertidal } \\
\text { mud and clay }\end{array}$ & $\begin{array}{l}6330 \pm 70 \mathrm{yrs} \\
\text { BP }\end{array}$ & $\begin{array}{l}\text { Dates the post } \\
\text { glacial estuary in } \\
\text { Lower Manawatu } \\
\text { Valley (Hesp and } \\
\text { Shepherd, 1978). }\end{array}$ \\
\hline NZ 3938B & $\begin{array}{l}\text { P. A. Hesp \& } \\
\text { M. J. Shepherd }\end{array}$ & $\begin{array}{l}5 \mathrm{~km} \text { west of } \\
\text { Tokomaru, } \\
40 \mathrm{~m} \text { below } \\
\text { ground level }\end{array}$ & $\begin{array}{l}\text { Podocarpus sp. } \\
\text { log in thick } \\
\text { gravel }\end{array}$ & $\begin{array}{l}41500 \pm 7450- \\
2800 \mathrm{yrs}^{1} \\
42700 \pm 7650- \\
3950 \mathrm{yrs}^{2}\end{array}$ & $\begin{array}{l}\text { Last glacial } \\
\text { floodplain deposit } \\
\text { (Hesp and } \\
\text { Shepherd, 1978). }\end{array}$ \\
\hline NZ 5128 & M. J. Shepherd & Manawatu & Shell, & $6280 \pm 220 y r s$ & Indicates a \\
\hline
\end{tabular}




\begin{tabular}{|c|c|c|c|c|c|}
\hline & & $\begin{array}{l}\text { floodplain, } \\
4 \mathrm{~km} \mathrm{SW} \text { of } \\
\text { Opiki, } 5.6 \mathrm{~m} \\
\text { depth in } \\
\text { borehole on } \\
\text { farm of G. K. } \\
\text { Murray. }\end{array}$ & $\begin{array}{l}\text { Austrovenus } \\
\text { stutchburyi, } \\
\text { within estuarine } \\
\text { mud and sand } \\
\text { which underlie } \\
10 \mathrm{~m} \text { alluvium. }\end{array}$ & & $\begin{array}{l}\text { Postglacial } \\
\text { estuary extended } \\
\text { inland to Opiki } \\
\text { (Shepherd, 1987). } \\
\text { Used by Gibb } \\
\text { (1983) to indicate } \\
\text { Manawatu is } \\
\text { subsiding }\end{array}$ \\
\hline NZ 5262A & L. J. Brown & $\begin{array}{l}\text { SH } 1 \text { near } \\
\text { Ohau. Sample } \\
68 \mathrm{~m} \text { below } \\
\text { ground level } \\
\text { (41m below } \\
\text { sea level). }\end{array}$ & $\begin{array}{l}\text { Shell, } \\
\text { Austrovenus } \\
\text { Stucthburyi }\end{array}$ & $\begin{array}{l}>35700 \mathrm{yrs}^{1} \\
>36700 \mathrm{yrs}^{2}\end{array}$ & $\begin{array}{l}\text { Last interglacial } \\
\text { marine deposit } \\
\text { correlation with } \\
\text { Otaki Formation }\end{array}$ \\
\hline NZ 5262B & L. J. Brown & $\begin{array}{l}\text { SH } 1 \text { near } \\
\text { Ohau. Sample } \\
60 \mathrm{~m} \text { below } \\
\text { ground level } \\
\text { ( } 33 \mathrm{~m} \text { below } \\
\text { sea level). }\end{array}$ & Peat & $\begin{array}{l}>36300 \mathrm{yrs}^{1} \\
>37400 \mathrm{yrs}^{2}\end{array}$ & $\begin{array}{l}\text { Last interglacial } \\
\text { marine deposit } \\
\text { correlated with } \\
\text { Otaki Formation }\end{array}$ \\
\hline
\end{tabular}

${ }^{1}$ Age with respect to old half life

${ }^{2}$ Age with respect to new half life 


\section{The University of Waikato \\ Radiocarbon Dating Laboratory}

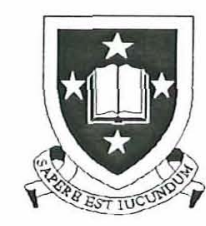

Private Bag 3105

Hamilton,

New Zealand.

Fax +6478384192

$\mathrm{Ph} \quad+6478384278$

emailc14@waikato.ac.nz

Head: Dr Alan Hogg

\section{Report on Radiocarbon Age Determination for Wk-}

13830

\author{
Submitter \\ Submitter's Code \\ Site \& Location \\ Sample Material \\ Physical Pretreatment
}

Chemical Pretreatment

\section{D.M Kennedy}

Levin30

Levin, lower North Island, New Zealand

wood

Surfaces scraped clean. The wood was chopped up into small splinters and milled. Washed in demineralized water and dried.

Solvent extracted. Treated with Sodium Chlorite to leave holocellulose. Treated with Sodium Hydroxide $(5 \% \mathrm{~W} / \mathrm{V})$ rinsed, washed with $10 \% \mathrm{HCl}$, rinsed and dried.

\section{Comments}

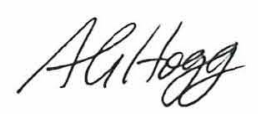

$11 / 12 / 03$

- Result is Conventional Age or \% Modern as per Stuiver and Polach, 1977, Radiocarbon 19, 355-363. This is based on the Libby half-life of $5568 \mathrm{yr}$ with correction for isotopic fractionation applied. This age is normally quoted in publications and must include the appropriate error term and Wk number.

- Quoted errors are 1 standard deviation due to counting statistics multiplied by an experimentally determined Laboratory Error Multiplier of 1

- The isotopic fractionation, $\delta^{13} C$, is expressed as $\%$ wrt PDB.

- Results are reported as \% Modern when the conventional age is younger than $200 \mathrm{yr}$ BP. 


\section{The University of Waikato \\ Radiocarbon Dating Laboratory}

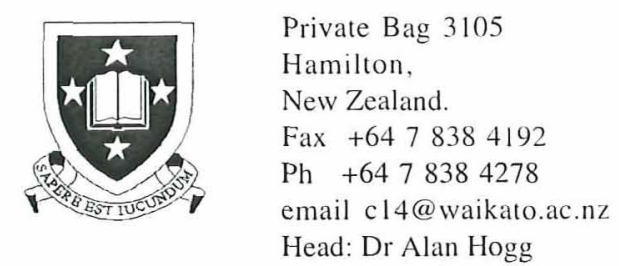

Report on Radiocarbon Age Determination for Wk-

13831

( AMS measurement by IGNS [NZA-18720] )

\author{
Submitter \\ Submitter's Code \\ Site \& Location \\ Sample Material \\ Physical Pretreatment
}

Chemical Pretreatment
D.M Kennedy

Levin75

Levin, lower North Island, New Zealand

Wood

Surfaces scraped clean. The wood was chopped up into small splinters and milled. Washed in demineralized water and dried.

Solvent extracted. Treated with Sodium Chlorite to leave holocellulose. Treated with Sodium Hydroxide (5\%W/V) rinsed, washed with $10 \% \mathrm{HCl}$, rinsed and dried.

\begin{tabular}{|lrl|}
\hline $\mathrm{d}^{14} \mathrm{C}$ & $-994.8 \pm 0.2$ & $\% 0$ \\
$\delta{ }^{13} \mathrm{C}$ & $-24.1 \pm 0.2$ & $\% 0$ \\
$\mathrm{D}^{14} \mathrm{C}$ & $-999.8 \pm 1.5$ & $\% 0$ \\
$\%$ Modern & $0.0 \pm 0.2$ & $\%$ \\
Result & $\mathbf{> 4 0 , 0 0 0 ~ B P}$ & \\
\hline
\end{tabular}

\section{Comments}

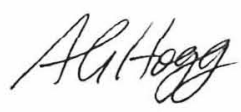

$11 / 12 / 03$

- Result is Conventional Age or \% Modern as per Stuiver and Polach, 1977, Radiocarbon 19, 355-363. This is based on the Libhy half-life of $5568 \mathrm{yr}$ with correction for isotopic fractionation applied. This age is normally quoted in publicattons and musi include the appropriate error term and $\mathrm{Wk}$ number.

- Quoted errors are 1 standard deviation due to counting statistics multiplied by an experimentally determined Laboratory Error Multiplier of 1

- The isotopic fractionation, $\delta^{13} \mathrm{C}$, is expressed as \%o wrt PDB.

- Results are reported as \% Modern when the conventional age is younger than $200 \mathrm{yr} \mathrm{BP}$. 
Appendix G:

NANNOFOSSIL DATA 
Horowhenua District Council's Levin Investigation Water Bore, at Neville Webb \& Son, west side of Main Road South, Levin. cable tool cuttings@131 - 132 m below ground level. dark grey slightly calcareous compact silty claystone.

Sample Number.

\section{CALCAREOUS NANNOFOSSILS: Detailed Analysis}

31 January 2005

CLIENT: Glenn Hughes, Victoria University of Wellington

Reference: $\quad$ A R Edwards, Stratigraphic Solutions Ltd. Job \#: 1090 LAB \#: C3443

\section{Biostratigraphy}

\section{Mid to Late Pleistocene.}

Biozone: $\quad$ lower to middle part of the Coccolithus pelagicus Zone (uWc-Now); possibly from the middle part of the zone.

Stage: $\quad$ upper Castlecliffian to middle Haweran (uWc - mWq; Middle to Upper Pleistocene; $\delta^{18} \mathrm{O}$ stages 12 to 3 ).

Also possible: middle Haweran (mWq; Middle to Upper Pleistocene; $\delta^{18} \mathrm{O}$ stages 8 to 3 ). Thus $\delta^{18} \mathrm{O}$ stages 5 or 7 seem slightly more likely than stages 9 or 11 .

Based on: the presence of Coccolithus pelagicus, the possible presence of Emiliania huxleyi (mWq Now; FO in $\delta^{18} \mathrm{O}$ stage 8) and the absence of common Emiliania huxleyi group (uWq Now; FCO in $\delta^{18} \mathrm{O}$ stage 4 or 3) \& of Pseudoemiliania lacunosa (uWo - mWc; LO in $\delta^{18} \mathrm{O}$ stage 12). In addition the nannofloral character is consistent with deposition during interglacial or peak interstadial conditions.

Assessment: estimated to be of moderate reliability.

Paleoenvironment
Tepid inshore near-surface water; fairly fast deposition onto a shallow seafloor.

Habitat: $\quad$ euphotic zone in a neritic Northern Transitional water mass.

Biofacies: fairly fast accumulation from quiet waters at littoral depths.

Based on: the abundance, composition, diversity and sedimentology of the nannoflora (including the presence of $C$. pelagicus braarudii and the absence of Gephrocapsa oceanica and many other taxa).

Assessment: $\quad$ estimated to be of moderate reliability.

ASSEMBLAGE

Abundance:

Diversity:

Grain-size:

Curation: rare, very depleted \& in fair condition

[Caution: this summary excludes "Admixed taxa" - see below for details].

Admixed taxa: some specimens have a noticably different preservation and/or age range. They are attributed to recycling from older marine strata - see below for further details.

Other microfossils: sporadic centric diatoms and fragments of pennate diatoms \& opaline sponge spicules.

Lithofacies (slide): $\quad$ opal bearing, carbon glass pyrite \& silt rich, clay.

\begin{tabular}{|c|c|c|}
\hline TAXON & AGE RANGE & COMMENTS \\
\hline Micrascidites vulgaris & $\mathrm{J}^{\wedge}$ - Now & trace [1]. \\
\hline Gephyrocapsa aperta & uWn - Now & rare [0], some without a bar. \\
\hline Helicosphaera carteri group & tLw - Now & $2[0]$ \\
\hline Coccolithus pelagicus braarudii & IWo - Now & sparse [0], most somewhat corroded, \\
\hline
\end{tabular}

(C) 2000 Stratigraphic Solutions Ltd, P O Box 295, Waikanae, Wellington 6454, New Zealand. Fascimile: +64 (4) 902-6344 Internet: biostrat@actrix.co.nz Voice:+64 (4) 902-6345 


\begin{tabular}{|c|c|c|}
\hline Emiliania huxleyi? & mWq - Now & $\begin{array}{l}\text { sparse }[0] \text {, son } \\
\text { gephyrocapsid. }\end{array}$ \\
\hline Admixed taxa include: & & \\
\hline Cyclicargolithus floridanus & lAr - tSl & $1[0] .$, reworked. \\
\hline Reticulofenestra pseudoumbilica grp. & $\mathrm{mPl}$ - tWo & 2 [0]., reworked. \\
\hline Reticulofenestra sp. indeterminate & uDm - tWo - uWc & 2 [0]., reworked. \\
\hline
\end{tabular}

Reticulofenestra sp. indeterminate

uDm - tWo - uWc

$2[0] .$, reworked.

\section{Comments:}

The rarity of in situ nannofossils may result from a combination of unfavourable environmental conditions (such as turbid water), dilution by other sediment and slightly corrosive ground water.

Aragonitic spicules of the benthic ascidian $M$. vulgaris, a taxon that prefers a shallow marine hard-ground habitat, occur in this sample.

This assemblage includes a very small admixed fraction attributed to recycling from marine strata of Mio-Pliocene age.

This sample contains a small diatom flora. Analysis of it would probably provide useful paleoenvironmental information. It's survival seems likely to be due to the buffering effect of the volcanic glass present in this sample.

Disclaimer: This analysis was unavoidably based on a lithologically composite sample and thus may contain significant interpretational errors.

(C) 2000 Stratigraphic Solutions LtD, P O Box 295, Waikanae, Wellington 6454, New Zealand. Fascimile: +64 (4) 902-6344 Internet: biostrat@actrix.co.nz Voice: +64 (4) 902-6345 
Horowhenua District Council's Levin Investigation Water Bore, at Neville Webb \& Son, west side of Main Road South, Levin. cable tool cuttings @ 212-213 m below ground level

CLIENT: $\quad$ Glenn Hughes, Victoria University of Wellington

Reference: $\quad$ A R Edwards, Stratigraphic Solutions Ltd. Job \#: 1090 LAB \#: C3444

BiostratigRAPHY

\section{Mid to Late Pleistocene.}

Biozone: $\quad$ lower to middle part of the Coccolithus pelagicus Zone (uWc-Now); possibly from the middle part of the zone.

Stage: $\quad$ upper Castlecliffian to middle Haweran (uWc - mWq; Middle to Upper Pleistocene; $\delta^{18} \mathrm{O}$ stages 12 to 3 ).

Also possible: middle Haweran (mWq; Middle to Upper Pleistocene; $\delta^{18} \mathrm{O}$ stages 8 to 3 ). Thus $\delta^{18} \mathrm{O}$ stages 5 or 7 seem slightly more likely than stages 9 or 11 .

Based on: the presence of Coccolithus pelagicus, the possible presence of Emiliania huxleyi (mWq Now; FO in $\delta^{18} \mathrm{O}$ stage 8) and the absence of common Emiliania huxleyi group (uWq Now; FCO in $\delta^{18} \mathrm{O}$ stage 4 or 3) \& of Pseudoemiliania lacunosa (uWo - mWc; LO in $\delta^{18} \mathrm{O}$ stage 12). In addition the nannofloral character is consistent with deposition during interglacial or peak interstadial conditions.

Assessment: estimated to be of moderate reliability.

Paleoenvironment

Habitat:

Biofacies:

Based on:

Assessment:

euphotic zone in a neritic southern Transitional water mass.

fairly fast accumulation from quiet waters at littoral depths.

the abundance, composition, diversity and sedimentology of the nannoflora (including the presence of $B$. bigelowii, $C$. pelagicus pelagicus and $M$. vulgaris).

estimated to be of moderate reliability.

\section{ASSEMBLAGE}

Abundance:

Diversity:

Grain-size:

Curation:

R:s S:c T:s M:p E: h23 + m4 + d0123 03/02

fairly rare, depleted \& in good condition but weakly size-sorted [Caution: this summary excludes "Admixed taxa" -see below for details].

Admixed taxa: attribu

Other microfossils:

Lithofacies (slide):
Preservation: good [some are fair].

Breakage: slight.

Etching: slight.

Plating: trivial.

\begin{tabular}{|lll}
\hline \multicolumn{1}{c}{ TAXON } & \multicolumn{1}{c}{ AGE RANGE } & \multicolumn{1}{c}{ COMmENTS } \\
\hline & & \\
Gephyrocapsa aperta & $\mathrm{uWn}$ - Now & few [0], many without a central bar. \\
Coccolithus pelagicus group & $\mathrm{lWo}-$ Now & sparse [0]. \\
Calcidiscus leptoporus & $\mathrm{mPl}-$ Now & $21 / 2[0]$, small. \\
Micrascidites vulgaris & $\mathrm{J} \wedge$ - Now & sparse [0]. \\
Gephyrocapsa oceanica group & IWc - Now & $1[0]$.
\end{tabular}

(C) 2000 Stratigraphic Solutions Ltd, P O Box 295, Waikanae, Wellington 6454, New Zealand. Fascimile: +64 (4) 902-6344 Internet: biostrat@actrix.co.nz Voice:+64 (4) 902-6345 


\section{Thoracosphaera heimii Helicosphaera carteri wallichii \\ Braarudosphaera bigelowii \\ Rhabdothorax regale \\ Emiliania huxleyi group? \\ Coccolithus pelagicus pelagicus}
$m M^{\wedge}$ - Wn - Now $1[0]$.
$10^{\wedge}-$ Now
bDt - Now
uTt - Now
mWq - Now
Wn? - Now
trace [0], $9 \mu \mathrm{m}$ @ 333/736, 7um @ 206/726 \& 347/764.
$1[0]$.
$1[0]$.
trace [0], could be a bar-less gephyrocasid. sparse [0].

Admixed taxa include:

Reticulofenestra pseudoumbilica gr. Cyclicargolithus floridanus

Tribrachiatus orthostylus

Zygrhablithus bijugatus

Chiasmolithus sp. indeterminate

Discoaster deflandrei

Discoaster lodoensis

Reticulofenestra placomorpha

Pseudoemiliania lacunosa

Discoaster brouweri

Reticulofenestra asanoi

mPl - tWo
lAr - tSl
mDw - mDm
mDw - mLw
lDt - lld
bLwh - mPl - ISl
mDm - lDp
uDp - lLwh
uWo - mWc
uTt - lWn
lWc - mWc

2 , battered, plated, reworked. trace, battered, plated, reworked, 1 , battered, plated, reworked, 1 , plated, reworked.

1 , battered, reworked.

1 , heavy plating, reworked.

1 , plated, reworked.

1 , corroded, reworked.

1, small, 5 um @ 390/781, reworked.

1, damaged, reworked.

1, small, damaged, 5 um @ 284/705, reworked?

Comments:

The preservation, size distribution, and taxonomic content of this nannoflora may result from a combination of unfavourable environmental conditions (such as turbid water) and dilution by other sediment,

Aragonitic spicules of the benthic ascidian M. vulgaris, a taxon that prefers a shallow marine hard-ground habitat, occur in this sample.

This assemblage includes (admixed) taxa attributed to recycling,from marine strata of various Cenozoic ages. This assessment plus the proximityof this site to the Manawatu River suggests that most of the recycled nannofossils in this sample were eroded from strata in southern Hawkes Bay (Eocene taxa), northern Waiarapa (Miocene taxa) and northern Manawatu (Plio-Pleistocene taxa). Some of the volcanic glass in this sample may have also been transported to this site by the river.

Disclaimer: This analysis was unavoidably based on a lithologically composite sample and thus may contain significant interpretational errors.

(C) 2000 Stratigraphic Solutions Ltd, P O Box 295, Waikanae, Wellington 6454, New Zealand. Fascimile: +64 (4) 902-6344 Internet: biostrat@actrix.co.nz Voice: +64 (4) 902-6345 
Horowhenua District Council's Levin Investigation Water Bore, at Neville Webb \& Son, west side of Main Road South, Levin. cable tool cuttings@228 to 229 m below ground level. dark grey slightly calcareous mudstone.

\section{CALCAREOUS NANNOFOSSILS: Detailed Analysis}

January 31, 2005

CLIENT: Glenn Hughes, Victoria University of Wellington

Reference: $\quad$ A R Edwards, Stratigraphic Solutions Ltd. Job \#: 1090 LAB \#: C3445

\section{Biostratigraphy \\ Mid to Late Pleistocene.}
Biozone: lower to middle part of the Coccolithus pelagicus Zone (uWc-Now); possibly from the lower part of the zone.
Stage: $\quad$ upper Castlecliffian to middle Haweran (uWc - mWq; Middle to Upper Pleistocene; $\delta^{18} \mathrm{O}$ stages 12 to 3 );
Also possible: upper Castlecliffian or lower Haweran (uWc - 1Wq; Middle Pleistocene). Thus $\delta^{18} \mathrm{O}$ stages 11 or 9 seem slightly more likely than stages 7 or 5 .
Based on: the presence of Coccolithus pelagicus, possible absence of Emiliania huxleyi (mWq - Now; FO in $\delta^{18} \mathrm{O}$ stage 8) and the absence of common Emiliania huxleyi group (uWq - Now; FCO in $\delta^{18} \mathrm{O}$ stage 4 or 3) \& of Pseudoemiliania lacunosa (uWo - mWc; LO in $\delta^{18} \mathrm{O}$ stage 12). In addition the nannofloral character is consistent with deposition during interglacial or peak interstadial conditions.
Assessment: estimated to be of moderate reliability.

Paleoenvironment
Cool nearshore near-surface water; fairly slow deposition onto a shallow seafloor.

Habitat: euphotic zone in a paralic southern Transitional water mass.

Biofacies: fairly fast accumulation from subdued waters at littoral depths.

Based on: the abundance, composition, diversity and sedimentology of the nannoflora (including the presence of B. bigelowii, C. pelagicus pelagicus and M. vulgaris).

Assessment: estimated to be of low moderate reliability.

AsSEMBLAGE very rare, depleted \& in fair condition but with some corrosion [this summary excludes "Admixed taxa" - see below for details].

$\begin{array}{llc}\text { Abundance: } & \text { sparse. } & \text { Preservation: fair [some are poor]. } \\ \text { Diversity: } & \text { low } & \text { Breakage: slight. } \\ \text { Grain-size: } & \text { mostly medium }(4-8 \mu \mathrm{m}) . & \text { Etching: obvious [some slight]. } \\ \text { Curation: } & \text { R:s s:c T:s M:p E:h23 }+\mathrm{m} 4+\mathrm{d} 123 \text { 03/02 } & \text { Plating: trivial. }\end{array}$

Admixed taxa: some specimens have a noticably different preservation and/or age range. They are attributed to recycling from older marine strata - see below for further details.

Other microfossils: sporadic fragments of diatoms and opaline sponge spicules.

Lithofacies (slide): carbon glass limemud \& pyrite bearing, clay rich, silt.

\begin{tabular}{|c|c|c|}
\hline TAXON & Age RANGE & COMMENTS \\
\hline Micrascidites vulgaris & $J^{\wedge}-$ Now & trace $[0]$. \\
\hline Thoracosphaera heimii & $m M \wedge-$ Now & $2[0]$ \\
\hline Calcidiscus leptoporus & mPl - Now & $2 \times 1 / 2[0]$, small. \\
\hline Coccolithus pelagicus group & IWo - Now & trace $[0]$ \\
\hline Braarudosphaera bigelowii & bDt - Now & $2[0]$ \\
\hline Gephyrocapsa sp. cf G. aperta & uWn - Now & sparse [0], corroded, no bar seen. \\
\hline
\end{tabular}

(C) 2000 Stratigraphic Solutions LtD, P O Box 295, Waikanae, Wellington 6454, New Zealand. Fascimile: +64 (4) 902-6344 Internet: biostrat@actrix.co.nz Voice: +64 (4) 902-6345 
Rhabdothorax regale

Coccolithus pelagicus pelagicus

Admixed taxa include:

Reticulofenestra pseudoumbilica grp. mPl - tWo

Cyclicargolithus floridanus

Coccolithus formosus

Chiasmolithus solitus

Sphenolithus neoabies

Reticulofenestra gelida
uTt - Now

Wn? - Now

$\mathrm{Ar}-\mathrm{tSl}$

$1 \mathrm{Ab}-\mathrm{ILwh}$

tDw - mAk

uTt - IWp

?T - uWo
1234 trace sparse [0], Od Ou Or trace. trace [0], reworked.

1 [0], reworked.

1 [0], reworked.

2 [0], reworked.

1 [0], reworked.

1 [0], reworked.

\section{Comments:}


Horowhenua District Council's Levin Invesigation Water Bore, at

Neville Webb \& Son, west side of Main Street South, Levin. cable tool cuttings@ 248 to 249 m below ground level.

\section{CALCAREOUS NANNOFOSSILS: Detailed Analysis}

January 31, 2005

CLIENT: $\quad$ Glenn Hughes, Victoria University of Wellington

Reference: $\quad$ A R Edwards, Stratigraphic Solutions Ltd. Job \#: 1090 Lab \#: C3446

\section{BiostratigRAPHY}

Mid to Late Pleistocene.

Biozone: $\quad$ lower to middle part of the Coccolithus pelagicus Zone (uWc-Now); possibly from the lower part of the zone.

Stage: $\quad$ upper Castlecliffian to middle Haweran (uWc - mWq; Middle to Upper Pleistocene; $\delta^{18} \mathrm{O}$ stages 12 to 3 ).

Also possible: upper Castlecliffian or lower Haweran (uWc - lWq; Middle Pleistocene). Thus $\delta^{18} \mathrm{O}$ stages 11 or 9 seem slightly more likely than stages 7 or 5 .

Based on: the presence of Coccolithus pelagicus, possible absence of Emiliania huxleyi (mWq Now; FO in $\delta^{18} \mathrm{O}$ stage 8) and the absence of common Emiliania huxleyi group (uWq Now; FCO in $\delta^{18} \mathrm{O}$ stage 4 or 3) \& of Pseudoemiliania lacunosa (uWo - mWc; LO in $\delta^{18} \mathrm{O}$ stage 12). In addition the nannofloral character is consistent with deposition during interglacial or peak interstadial conditions.

Assessment: estimated to be of moderate reliability.

Paleoenvironment

Biofacies:

Based on:

Assessment:

\section{Tepid slightly brackish inshore near-surface water;} fairly fast deposition onto a shallow seafloor.

\section{ASSEMBLAGE}

euphotic zone in a paralic southern Transitional water mass.

$$
\text { fairly fast accumulation from subdued waters at littoral depths. }
$$

the abundance, composition, diversity and sedimentology of the nannoflora (including the presence of $B$. bigelowii, $C$. pelagicus braarudii, $C$. pelagicus pelagicus, and $M$. vulgaris).

estimated to be of moderate reliability.

very rare, depleted \& in fair condition but moderately size-sorted [Caution: this summary excludes "Admixed taxa" - see below for details].

Abundance: sparse.

Diversity: low.

Grain-size: mostly medium (4-8 $\quad$ mm).

Curation: $\quad$ R:s s:c T:s M:p E: h23 + m4 + d123 03/02

Admixed taxa: many specimens have a noticably different preservation and/or age range. They are attributed to recycling from older marine strata - see below for further details.

Other microfossils: sporadic fragments of centric pennate diatoms and sparse fragments of opaline sponge spicules.

Lithofacies (slide): carbon glass limemud opal \& pyrite bearing, clay rich, silt.

\begin{tabular}{|c|c|c|}
\hline TAXON & Age RANGE & COMMENTS \\
\hline Micrascidites vulgaris & J^ - Now & sparse [3]. \\
\hline Braarudosphaera bigelowii & bDt - Now & trace [0], 2 pentaliths, $6 \mu \mathrm{m}$, @378/764. \\
\hline Coccolithus pelagicus braarudii & lWo - Now & sparse [0]. \\
\hline Emiliania huxleyi group & $\mathrm{mWq}$ - Now & $3[0]$ \\
\hline Gephyrocapsa aperta & uWn - Now & trace [0], many without cross-bar. \\
\hline
\end{tabular}

(C) 2000 Stratigraphic Solutions Ltd, P O Box 295, Waikanae, Wellington 6454, New Zealand. Fascimile: +64 (4) 902-6344 Internet: biostrat@actrix.co.nz Voice:+64 (4) 902-6345 
Helicosphaera carteri group

Rhabdothorax regale

Pontosphaera discopora

Thoracosphaera heimii

Reticulofenestra sp. indet.

Calcidiscus leptoporus

Coccolithus pelagicus pelagicus

Admixed taxa include:

Chiasmolithus solitus

Reticulofenestra pseudoumbilica grp.

Cyclicargolithus floridanus

Sphenolithus compactus

Gephyrocapsa "neosinuosa" MS
tLw - Now
uTt - Now
lTk - Now
$3[0]$.
$\mathrm{mM} \wedge$ - Now
$u D m-u W c$
mPl - Now
Wn? - Now
4 [0], 1 cluster seen.
$1[0]$.
$3[0]$.
trace [0], small \& tiny with closed centre \& no cross-bar.
$11 \frac{1}{2}[0]$.
trace [0].

tDw - mAk

2, reworked.

$\mathrm{mPl}$ - tWo

trace, reworked.

trace, reworked.

1 , reworked.

$\mathrm{bM} \wedge-\mathrm{bTt}$

bWc - mWc

\section{Comments:}

The rarity of in situ nannofossils may result from a combination of unfavourable environmental conditions (such as turbid water), dilution by other sediment and sediment sorting by bottom currents. Aragonitic spicules of the benthic ascidian M. vulgaris, a taxon that prefers a shallow marine hard-ground habitat, occur in this sample.

This assemblage includes a substantial admixed fraction attributed to recycling from various marine strata of mid (mostly) and early Cenozoic age. This information plus the proximity of this site to the present day Manawatu River suggests that most of the recyled nannofossils in this sample were eroded from strata near Dannevirke, southern Hawkes Bay. Some of the volcanic glass in this sample may have also been transported to this site by the river.

Disclaimer: This analysis was unavoidably based on a lithologically composite sample of drill cuttings and thus may contain significant interpretational errors.

(C) 2000 Stratigraphic Solutions Ltd, P O Box 295, Waikanae, Wellington 6454, New Zealand. Fascimile: +64 (4) 902-6344 Internet: biostrat@actrix.co.nz Voice: +64 (4) 902-6345 


\section{Appendix H: \\ TEPHRA GLASS CHEMISTRY}

\section{Processing of samples}

Tephra analysis was carried out using electron microprobe analysis as prescribed by Froggatt (1983). The term tephra is referred to here as all unconsolidated pyroclastic products of a volcanic eruption, regardless of the final mode of deposition (e.g. Froggatt and Lowe, 1990). Samples containing tephritic glass shards were processed by crushing and disaggregating grains, and wet sieving through a 60 micron monolen cloth to remove mud sized particles ( $<60$ microns). The sand fraction $(60-250 \mu \mathrm{m})$ was then oven dried at $40^{\circ} \mathrm{c}$ for 24 hours.

\section{Electron microprobe analysis}

A small proportion of the sand fraction was mounted in a resin block and polished to produce a thin section, which was later coated in carbon. Geochemistry was analysed using the Jeol-733 superprobe at Victoria University. Ten to 15 individual glass shards with flat, well polished surfaces were selected for analysis. Values of major oxide composition were determined using a beam current of $8.0 \mathrm{nA}$ at $15 \mathrm{kV}$ and beam diameter of $10 \mu \mathrm{m}$. A regular machine calibration was undertaken to reduce errors. However, possible errors may result from either poor shard selection or contamination; although, there are no results to suggest significant errors were made.

\section{Analytical results}

All glass shards analysed contained between $74-79 \% \mathrm{SiO}_{2}$ and 6-7\% alkali content (total $\mathrm{Na}_{2} \mathrm{O}+\mathrm{K}_{2} \mathrm{O}$ ) indicating calc-alkaline rhyolite composition (Shane et al., 1996). The glass composition is broadly similar to tephras erupted from the TVZ during the Pleistocene (see below). Analytical totals ranged from $93 \%$ to $96 \%$, typical of New Zealand Late Cenozoic glasses (Shane, 2000); the discrepancy from 100\% being largely due to water, not analysed using the microprobe, which is incorporated into the glass 
structure following deposition (Froggatt, 1983). Major oxide totals were recalculated to $100 \%$ on a water free basis to provide valid statistical results.

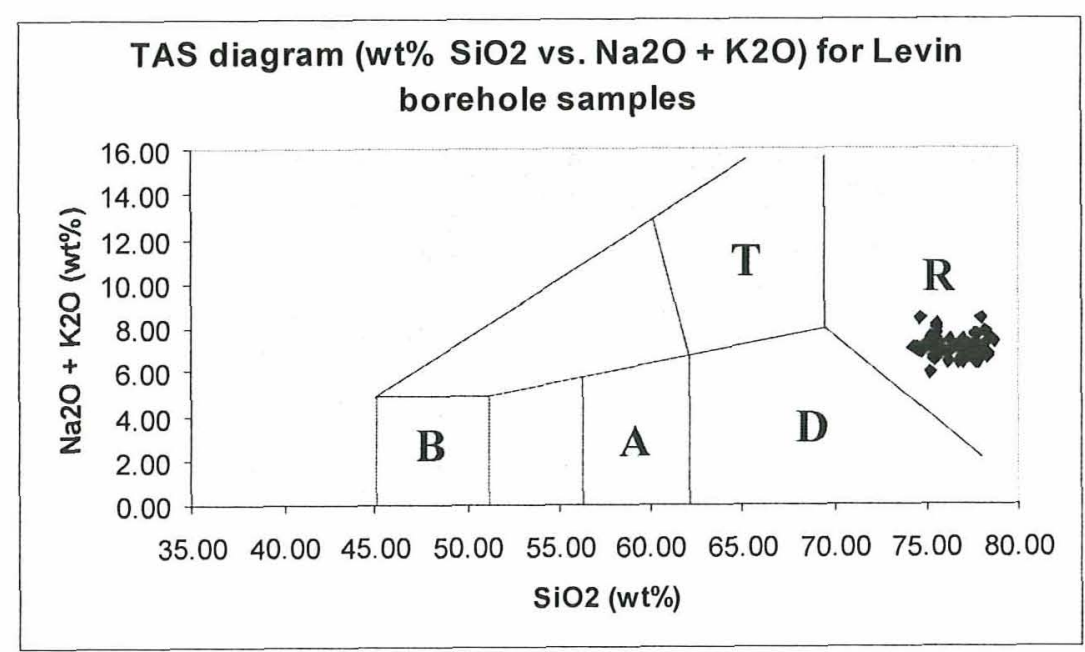

Total Alkali Silica diagram showing that all distal tephras found in Levin borehole are Taupo Volcanic Zone derived rhyolites. Compositrional fields from Shane et al. (1996); $\mathrm{R}$ rhyolite, $\mathrm{D}$ dacite, T trachyte, A andesite, $\mathrm{B}$ basalt. 
Summary of glass chemistry

\begin{tabular}{|l|l|l|l|l|l|l|l|l|l|l|l}
\hline Sample & $\mathrm{SiO} 2$ & $\mathrm{Al} 2 \mathrm{O} 3$ & $\mathrm{TiO} 2$ & $\mathrm{FeO}$ & $\mathrm{MnO}$ & $\mathrm{MgO}$ & $\mathrm{CaO}$ & $\mathrm{Na} 2 \mathrm{O}$ & $\mathrm{K} 2 \mathrm{O}$ & $\mathrm{Cl}$ & Water \\
\hline
\end{tabular}

| Cluster

(excluding outliers)

\begin{tabular}{|c|c|c|c|c|c|c|c|c|c|c|c|}
\hline $131-132 m$ & & & & & & & & & & & \\
\hline glass 1 & 74.55 & 14.33 & 0.20 & 2.08 & 0.13 & 0.09 & 1.18 & 3.46 & 3.73 & 0.26 & 6. \\
\hline glass 2 & 75.19 & 13.70 & 0.13 & 2.17 & 0.17 & 0.13 & 0.90 & 3.61 & 3.88 & 0.13 & 4.26 \\
\hline glass 3 & 75.56 & 13.81 & 0.20 & 2.07 & 0.12 & 0.09 & 1.22 & 3.47 & 3.26 & 0.20 & \\
\hline glass 4 & 75.61 & 13.79 & 0.22 & 2.27 & 0.07 & 0.13 & 1.14 & 3.27 & 3.23 & 0.27 & \\
\hline glass 5 & 78.49 & 12.34 & 0.19 & 1.31 & 0.09 & 0.22 & 1.34 & 3.01 & 2.91 & 0.11 & \\
\hline glass 6 & 75.67 & 13.96 & 0.11 & 2.28 & 0.09 & 0.14 & 1.13 & 3.21 & 3.20 & 0.20 & \\
\hline glass 7 & 75.45 & 13.91 & 0.15 & 2.13 & 0.03 & 0.09 & 1.10 & 3.65 & 3.25 & 0.23 & \\
\hline glass 8 & 77.72 & 13.01 & 0.16 & 0.98 & 0.09 & 0.05 & 0.79 & 3.27 & 3.58 & 0.34 & \\
\hline glass 9 & 74.96 & 13.99 & 0.17 & 2.24 & 0.06 & 0.14 & 1.05 & 3.55 & 3.58 & 0.25 & \\
\hline glass 10 & 75.36 & 14.20 & 0.09 & 2.19 & 0.14 & 0.17 & 1.20 & 3.22 & 3.16 & 0.26 & \\
\hline glass 11 & 75.21 & 13.83 & 0.23 & 2.06 & 0.13 & 0.11 & 1.02 & 3.55 & 3.68 & 0.19 & \\
\hline $191-1928$ & $200 \mathrm{~m}$ & & & & & & & & & & \\
\hline glass 1 & 75.41 & 14.13 & 0.23 & 2.05 & 0.13 & 0.15 & 1.23 & 3.15 & 3.28 & 0.24 & \\
\hline glass 2 & 77.95 & 12.70 & 0.14 & 0.91 & 0.13 & 0.11 & 0.68 & 2.51 & 4.67 & 0.20 & \\
\hline glass 3 & 76.81 & 13.16 & 0.13 & 1.36 & 0.04 & 0.14 & 0.93 & 3.18 & 3.99 & 0.27 & \\
\hline glass 4 & 77.91 & 12.38 & 0.15 & 1.13 & 0.22 & 0.06 & 0.90 & 3.14 & 3.87 & 0.24 & \\
\hline glass 5 & 76.19 & 13.91 & 0.07 & 1.87 & 0.00 & 0.11 & 1.04 & 3.04 & 3.54 & 0.23 & \\
\hline glass 6 & 78.18 & 12.64 & 0.11 & 0.91 & 0.03 & 0.08 & 070 & 286 & 422 & 0.23 & \\
\hline
\end{tabular}

206-208m

\begin{tabular}{lllll}
\cline { 1 - 2 } glass 1 & 76.61 & 13.05 & 0.16 & 1.05 \\
glass 2 & 75.52 & 13.32 & 0.18 & 1.81
\end{tabular}

\begin{tabular}{lllll} 
glass 2 & 75.52 & 13.32 & 0.18 & 1.81 \\
\hline glass 3 & 78.18 & 12.87 & 0.11 & 1.04
\end{tabular}

glass 5

glass 6

glass

glass 8
glass 9

glass 10

$78.18 \quad 12.87$

$\begin{array}{llll}78.41 & 12.53 & 0.08 & 0.85\end{array}$

$\begin{array}{llll}75.44 & 1.42 & 0.10 & 1.13\end{array}$

$\begin{array}{llll}75.91 & 13.39 & 0.19 & 1.86 \\ 78.63 & 12.16 & 0.06 & 1.91\end{array}$

$\begin{array}{lll}78.63 & 12.16 & 0.06\end{array}$

228-229m

glass 1

$\begin{array}{lll}76.08 & 13.48 & 0.23\end{array}$

$\begin{array}{ll}.17 & 1.33 \\ 0.23 & 1.97\end{array}$

$\begin{array}{ll}1.33 & 0.01 \\ 1.97 & 0.10\end{array}$

$\begin{array}{lllll}0.07 & 0.07 & 1.12 & 3.40 & 3.55\end{array}$

$\begin{array}{lllll}0.14 & 0.09 & 0.85 & 2.59 & 3.88\end{array}$

$\begin{array}{lllll}0.04 & 0.14 & 0.87 & 2.80 & 4.06\end{array}$

$\begin{array}{lllll}0.03 & 0.08 & 0.72 & 3.27 & 4.05\end{array}$

$\begin{array}{lllll}0.08 & 0.08 & 0.90 & 2.97 & 4.71 \\ 0.00 & 0.04 & 0.91 & 3.46 & 3.96\end{array}$

$\begin{array}{lllll}0.09 & 0.16 & 1.06 & 2.77 & 3.82\end{array}$

$\begin{array}{lllll}0.01 & 0.12 & 0.86 & 3.43 & 3.7 \\ 0.10 & 0.13 & 1.06 & 3.30 & 3.43\end{array}$

$\begin{array}{ll}0.24 & 4.17 \\ 0.24 & 4.29\end{array}$

$\begin{array}{lr}0.22 & 4.08 \\ 0.26 & 2\end{array}$

$\begin{array}{lr}0.26 & 2 \\ 0.27 & 2.39\end{array}$

$\begin{array}{lr}0.23 & 2.5\end{array}$

$\begin{array}{ll}0.18 & 4.37 \\ 0.24 & 5.07\end{array}$

$\begin{array}{ll}0.24 & 5.07 \\ 0.22 & 5.87\end{array}$

\begin{tabular}{|c|c|c|c|c|c|c|c|c|c|c|}
\hline glass 1 & 77.35 & 12.91 & 0.16 & 1.01 & 0.12 & 0.06 & 0.97 & 3.26 & 3.96 & 0.20 \\
\hline glass 2 & 75.77 & 13.99 & 0.11 & 1.70 & 0.15 & 0.11 & 1.13 & 3.31 & 3.59 & 0.14 \\
\hline glass 3 & 77.59 & 12.82 & 0.13 & 0.98 & 0.01 & 0.11 & 0.82 & 2.95 & 4.34 & 0.24 \\
\hline glass 4 & 77.49 & 12.89 & 0.18 & 1.11 & 0.10 & 0.08 & 0.95 & 3.19 & 3.76 & 0.24 \\
\hline glass 5 & 77.05 & 13.40 & 0.18 & 1.37 & 0.00 & 0.09 & 0.81 & 3.24 & 3.60 & 0.26 \\
\hline glass 6 & 78.35 & 12.36 & 0.16 & 0.81 & 0.12 & 0.10 & 0.77 & 2.94 & 4.19 & 0.19 \\
\hline glass 7 & 77.26 & 13.17 & 0.17 & 1.13 & 0.07 & 0.12 & 0.83 & 2.87 & 4.07 & 0.31 \\
\hline glass 8 & 77.10 & 12.97 & 0.09 & 0.93 & 0.09 & 0.12 & 0.81 & 3.38 & 4.25 & 0.24 \\
\hline glass 9 & 75.45 & 13.90 & 0.18 & 1.99 & 0.13 & 0.14 & 1.13 & 3.22 & 3.58 & 0.27 \\
\hline glass 10 & 77.71 & 12.79 & 0.05 & 0.92 & 0.08 & 0.10 & 0.73 & 3.22 & 4.15 & 0.23 \\
\hline glass 11 & 76.12 & 13.65 & 0.19 & 2.08 & 0.11 & 0.05 & 1.00 & 3.00 & 3.58 & 0.20 \\
\hline glass 12 & 74.67 & 14.26 & 0.18 & 2.37 & 0.07 & 0.17 & 0.92 & 3.68 & 3.49 & 0.19 \\
\hline glass 13 & 75.42 & 14.04 & 0.19 & 2.06 & 0.15 & 0.09 & 1.05 & 3.29 & 3.52 & 0.20 \\
\hline \multicolumn{11}{|l|}{$259-260 \mathrm{~m}$} \\
\hline glass 1 & 75.61 & 13.85 & 0.23 & 2.05 & 0.16 & 0.06 & 1.16 & 3.46 & 3.20 & 0.22 \\
\hline glass 2 & 76.25 & 13.58 & 0.16 & 1.85 & 0.08 & 0.13 & 1.01 & 3.41 & 3.38 & 0.15 \\
\hline glass 3 & 75.44 & 13.74 & 0.13 & 1.58 & 0.04 & 0.11 & 0.99 & 3.47 & 4.30 & 0.19 \\
\hline glass 4 & 76.90 & 13.23 & 0.14 & 1.43 & 0.04 & 0.07 & 0.91 & 3.17 & 3.95 & 0.15 \\
\hline glass 5 & 77.60 & 13.01 & 0.14 & 1.20 & 0.00 & 0.06 & 0.97 & 3.05 & 3.86 & 0.12 \\
\hline glass 6 & 77.87 & 12.82 & 0.06 & 0.92 & 0.07 & 0.11 & 0.77 & 3.17 & 4.06 & 0.16 \\
\hline glass 7 & 77.78 & 12.54 & 0.07 & 0.75 & 0.21 & 0.09 & 0.80 & 3.02 & 4.52 & 0.22 \\
\hline glass 8 & 77.56 & 1241 & 0.08 & 0.87 & 0.10 & 0.10 & & 197 & & \\
\hline
\end{tabular}

277-278m

glass 1

glass

$\begin{array}{llll}74.28 & 13.86 & 0.18 & 1.84 \\ 77.27 & 13.14 & 0.08 & 1.17\end{array}$

$\begin{array}{ll}74.50 & 14.05\end{array}$

glass 5

$\begin{array}{lll}\text { glass } 6 & 77.16 & 12.72\end{array}$

glass $7 \quad 75.47 \quad 13.47$

$\begin{array}{lll}\text { glass } 8 & 75.18 & 13.41 \\ \text { glass 9 } & 76.97 & 13.34\end{array}$

glass $10 \quad 77.38 \quad 13.08$

$\begin{array}{lll}\text { glass } 11 & 78.29 & 12.51\end{array}$

$\begin{array}{lll}\text { glass } 12 & 76.76 & 12.77\end{array}$

$\begin{array}{lll}\text { glass 13 } & 77.68 & 12.82 \\ \text { glass 14 } & 76.37 & 13.76\end{array}$

$\begin{array}{lll}0.18 & 1.84 & 0.11 \\ 0.08 & 1.17 & 0 . \\ 0.18 & 1.87 & 0.00 \\ 0.08 & 2.11 & 0.05 \\ 0.14 & 1.95 & 0.01 \\ 0.09 & 1.30 & 0.10 \\ \mathbf{0 . 2 3} & 1.99 & 0.08 \\ \mathbf{0 . 1 9} & \mathbf{2 . 0 9} & 0.02 \\ \mathbf{0 . 1 5} & 1.24 & 0.03 \\ \mathbf{0 . 0 6} & 1.02 & 0.02 \\ \mathbf{0 . 1 2} & \mathbf{0 . 9 7} & 0.02 \\ 0.17 & 1.61 & 0.07 \\ \mathbf{0 . 1 2} & 1.22 & 0.08 \\ \mathbf{0 . 1 3} & \mathbf{1 . 9 8} & 0.06\end{array}$

$\begin{array}{lllllll}0.11 & 0.11 & 1.04 & 3.03 & 5.35 & 0.19 & 3.41 \\ 0.10 & 0.09 & 0.92 & 3.33 & 3.67 & 0.21 & 4.48 \\ 0.00 & 0.09 & 0.96 & 4.08 & 4.04 & 0.23 & 5.15 \\ 0.05 & 0.05 & 1.02 & 3.70 & 4.18 & 0.16 & 3.88 \\ 0.01 & 0.10 & 1.11 & 3.60 & 3.86 & 0.19 & 4.21 \\ 0.10 & 0.13 & 1.13 & 3.21 & 3.97 & 0.19 & 1.64 \\ 0.08 & 0.12 & 0.95 & 3.24 & 4.29 & 0.16 & 5.51 \\ 0.02 & 0.14 & 1.15 & 2.97 & 4.65 & 0.20 & 5.1 \\ 0.03 & 0.13 & 0.85 & 3.36 & 3.64 & 0.28 & 6.68 \\ 0.02 & 0.13 & 0.64 & 3.31 & 4.09 & 0.27 & 5.83 \\ 0.02 & 0.06 & 0.59 & 3.56 & 3.66 & 0.22 & 5.24 \\ 0.07 & 0.07 & 0.86 & 3.49 & 3.88 & 0.32 & 3.76 \\ 0.08 & 0.09 & 0.69 & 2.39 & 4.66 & 0.25 & 7.51 \\ 0.06 & 0.08 & 0.98 & 2.97 & 3.49 & 0.17 & 7.19\end{array}$

